\author{
UNIVERSIDADE DE SÃO PAULO \\ INSTITUTO DE ENERGIA E AMBIENTE \\ PROGRAMA DE PÓS-GRADUAÇÃO EM CIÊNCIA AMBIENTAL
}

\title{
LOREN BELEI
}

What is needed to implement a forest and landscape restoration intervention? Development of a socioeconomic standard 


\section{LOREN BELEI}

What is needed to implement a forest and landscape restoration intervention? Development of a socioeconomic standard

Versão Original

Dissertação apresentada ao Programa de PósGraduação em Ciência Ambiental do Instituto de Energia e Ambiente da Universidade de São Paulo, para obtenção do título de Mestre em Ciência Ambiental.

Orientadora: Profa. Dra. Carla Morsello

São Paulo 
AUTORIZO A REPRODUÇÃO E DIVULGAÇÃO TOTAL OU PARCIAL DESTE TRABALHO, POR QUALQUER MEIO CONVENCIONAL OU ELETRÔNICO, PARA FINS DE ESTUDO E PESQUISA, DESDE QUE CITADA A FONTE.

FICHA CATALOGRÁFICA

Belei, Loren

What is needed to implement a forest and landscape restoration intervention? Development of a socioeconomic standard. / Loren Belei; orientadora: Carla Morsello. - São Paulo, 2019.

163 f.: il., $30 \mathrm{~cm}$

Dissertação (Mestrado em Ciência Ambiental) - Programa de PósGraduação em Ciência Ambiental - Instituto de Energia e Ambiente da Universidade de São Paulo, São Paulo, 2019

1. Florestas - restauração - aspectos socioeconômicos. 2. Paisagem - restauração - aspectos socioeconômicos. I. Título.

Elaborado por Maria Penha da Silva Oliveira CRB-8/6961 
FOLHA DE APROVAÇÃO

What is needed to implement a forest and landscape restoration intervention?

Development of a socioeconomic standard

Aluna: Loren Belei

Orientadora: Profa. Dra. Carla Morsello

Dissertação apresentada ao Programa de PósGraduação em Ciência Ambiental do Instituto de Energia e Ambiente da Universidade de São Paulo, para obtenção do título de Mestre em Ciência Ambiental.

Aprovado em:

\section{BANCA EXAMINADORA}

Prof.(a) Dr.(a)

Instituiç̧ão: Julgamento:

Assinatura:

Prof.(a) Dr.(a)

Instituição: Julgamento:

Assinatura:

Prof.(a) Dr.(a)

Instituição: Julgamento:

Assinatura:

Presidente:

Prof.(a) Dr.(a)

Instituição:

Assinatura: 
DEDICATÓRIA

Dedico esta Dissertação a todos aqueles que se emprenham em restaurar florestas e paisagens. 
Em primeiro lugar, agradeço imensamente à Carla Morsello, que além de orientadora, foi uma grande incentivadora e conselheira. Obrigada pela paciência, dedicação e preocupação, tanto com a pesquisa, quanto comigo. Obrigada também por abrir as portas da sua casa, por sempre confiar na minha capacidade e por dar as dicas e puxões de orelha necessários. Sem a sua participação essa trajetória com certeza teria sido mais difícil.

Agradeço à minha mãe que durante todos esses anos sempre esteve ao meu lado, sem duvidar de que seria capaz de realizar o que quisesse. Obrigada pela vida e por tudo que faz por mim até hoje. Obrigada também pela base e pela preocupação com meus estudos.

À minha irmãzinha, Lan, que é sempre uma fonte de ânimo e de alegria para mim. Obrigada por me guiar nessa vida, por todos os conselhos e por me fazer enxergar as coisas sempre com o olhar mais positivo. Sua força e coragem me inspiram. Logo te encontro pela Índia (ou em qualquer outro canto do mundo que você estiver.

À Carolzinha, minha grande parceira durante todo o mestrado, não só de trabalho e pesquisa, mas de amizade. Nós já repetimos isso mil vezes, mas você é um grande presente que a vida acadêmica trouxe. Muito obrigada por ser um centrinho de paz durante essa trajetória e por sempre me lembrar que as coisas iam dar certo (EISGBAR!). Agradeço também ao Du, pela parceria nos perrengues em campo, obrigada pela companhia e amizade.

À minha grande amiga Mari, que sempre me entendeu, apoiou e dividiu as alegrias e dificuldades da vida acadêmica. Sem você esse trajeto não teria tanta graça, Maricota. Obrigada por sua amizade, cuidado, alegria, por sempre se preocupar se vai ter algo vegano pra eu comer e por confiar em mim para cuidar dos Ticos.

Ao Luquita, que me acompanhou nos últimos meses dessa trajetória, sempre me incentivando e injetando o ânimo necessário para eu conseguisse finalizar minha pesquisa. Obrigada por entender e por acompanhar os finais de semana de trabalho, por tornar esses momentos mais divertidos e por ajudar em tudo que fosse possível. E principalmente, obrigada por sempre sempre sempre me lembrar que vai ficar tudo bem. Obrigada pelo carinho e compreensão, meu amor.

Aos queridos Cauê e Pri, pelas conversas sobre pesquisa, pelas trocas sobre a vida e planos futuros e pelos encontros divertidos, sempre acompanhados de muita risada e cantoria. 
Lia e Isa, obrigada por dividirem esses anos de trabalho, misturados entre discussões acadêmicas, conversas sobre yoga e comidinhas orgânicas do MST.

À Juliana, valeu por sempre estar ao meu lado (literalmente!), por botar fé em mim, ouvir minhas reclamações e fazer meus dias mais felizes. Obrigada por ser quem é, por compartilhar os dias de trabalho comigo e por sempre estar presente quando eu precisei de uma pausa para colocar a cabeça no lugar.

Agradeço também ao Carlinhos e todos os outros amigos da EDP, que dividem comigo seu conhecimento, experiência e amizade. Obrigada pela compreensão com os compromissos do mestrado e por permitirem que eu trilhasse esses dois caminhos ao mesmo tempo.

Muito obrigada à Thai pela companhia durante todos esses anos de amizade, por fazer parte da minha história e por sempre acreditar em mim.

Agradeço à Victoria Gutierrez, Ricardo César e todo o pessoal da WeForest e também aos Professores Pedro Brancalion e Ricardo Viani, por me acolherem neste projeto de pesquisa. Agradeço à oportunidade, apoio financeiro, confiança e respeito durante todo o trajeto.

À CAPES pelo apoio financeiro que permitiu que essa pesquisa fosse realizada. À Universidade de São Paulo, ao Instituto de Energia e Ambiente e à Escola de Artes Ciências e Humanidades por todo aprendizado, desde a época da graduação.

Ao pessoal do IPE, por abrirem as portas de seu projeto de restauração me permitindo ver na prática as dificuldades, o enorme trabalho que está por trás de um projeto deste tipo e principalmente, para que pudesse ver de perto as transformações que este tipo de trabalho pode trazer.

E por fim, obrigada a todos aqueles que ao longo destes anos compartilharam e contribuíram de alguma forma com a minha trajetória até a finalização da minha pesquisa. 
O interesse por projetos de restauração ecológica e restauração florestal tem crescido tanto no campo científico, quanto no campo prático de políticas públicas e da sociedade civil. A razão para tal é o aumento no número de acordos internacionais (e.g., acordo de Paris) e iniciativas nacionais que impulsionam políticas públicas e o interesse da iniciativa privada em projetos de restauração, especialmente como forma de mitigar as emissões de carbono. Mais recentemente, os projetos de restauração adotaram novas abordagens, visando torná-los mais efetivos e aplicáveis a escalas amplas e que incluem usos antrópicos do solo. A Restauração de Florestas e Paisagens é uma dessas abordagens, que procura abarcar não somente objetivos ecológicos de restauração florestal, mas também aspectos sociais e econômicos, com o objetivo de promover a melhoria nos meios de vida dos atores da paisagem envolvida. Difere das demais abordagens pois não foca apenas em restauração das terras degradadas, mas visa acoplar a restauração florestal aos demais usos antrópicos da terra produzindo paisagens multifuncionais. A despeito do interesse crescente nos projetos de restauração, faz-se necessário avançar na elaboração e implantação de ferramentas que visem verificar o cumprimento dos objetivos e impactos socioeconômicos dos projetos de restauração, especialmente em abordagens mais complexas como a de paisagens. Este projeto tem portanto, o objetivo de identificar os princípios necessários para tal, e propor um esquema de padronização dos aspectos socioeconômicos para projetos de restauração de florestas e paisagens. Para isso, o projeto possui duas etapas. A primeira serviu para identificar os principais conceitos e princípios da Restauração de Florestas e Paisagens. Na segunda etapa, elaborar um esquema de padronização dos aspectos socioeconômicos, que possa ser adequado a contextos diversos e que visa auxiliar no planejamento, implementação de monitoramento dos projetos.

Palavras-chave: Restauração de Florestas e Paisagens; Aspectos Socioeconômicos; Princípios Socioeconômicos; Esquema de Padronização. 
Interest in ecological restoration and forest restoration projects has grown both in the scientific and practical fields of public policy and civil society. The reason for this is the increase in the number of international agreements (e.g., Paris agreement) and national initiatives that drive public policy and the interest of private enterprise in restoration projects, especially as a means of mitigating carbon emissions. More recently, restoration projects have adopted new approaches to make them more effective and applicable at large scales and including anthropogenic land uses. The Restoration of Forests and Landscapes is such approach, which seeks to encompass not only ecological objectives of forest restoration, but also social and economic aspects, with the aim of promoting the livelihoods of the actors of the landscape involved. It differs from other approaches since it does not only focus on restoration of degraded lands but aims to couple forest restoration with other anthropogenic land uses producing multifunctional landscapes. Despite the growing interest in restoration projects, it is necessary to further develop and implement tools to verify compliance with restoration projects' objectives and socioeconomic impacts, especially in more complex approaches such as landscapes. This project therefore aimed to identify the necessary principles and propose a standard framework of socioeconomic aspects for forest and landscape restoration projects. The project was done in two steps. The first served to identify the main concepts and principles of Forest and Landscape Restoration. In the second stage, develop a standardization scheme of socioeconomic aspects, which may be suitable for different contexts and which aims to assist in the planning, implementation of project monitoring.

Keywords: Forest and Landscape Restoration; Socioeconomic aspects; Socioeconomic Principles; Standardization Scheme. 
Table 1. FLR Organisations and documents available in the Google search........................23

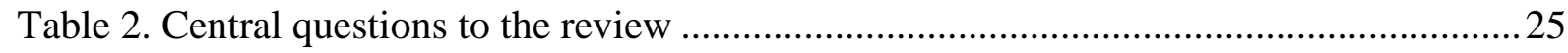

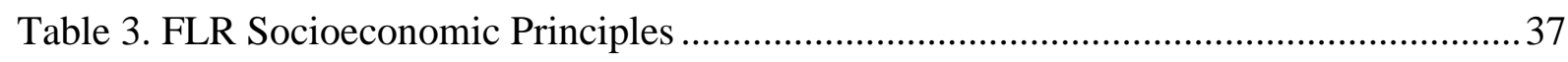

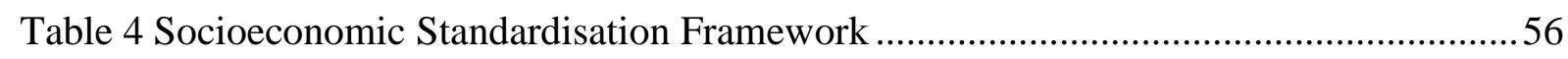




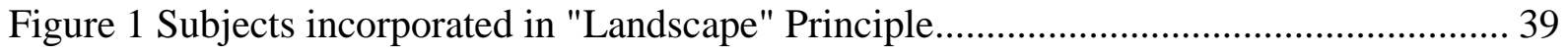

Figure 2 Subjects incorporated in "Mitigation of Inequalities" Principle .............................. 40

Figure 3 Subjects incorporated in "Human Resilience" Principle ........................................ 41

Figure 4 Principle Landscape from Planning and Implementation Category ......................... 73

Figure 5 Principle Legal and Normative Compliance from Planning and Implementation

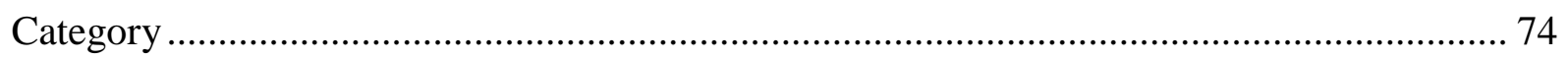

Figure 6 Principle Mitigation of Inequalities from Planning and Implementation Category .. 75

Figure 7 Principle Human Resilience from Expected Outcomes Category ............................ 77

Figure 8 Principle Adaptive Management from Management and Monitoring Category ....... 78 


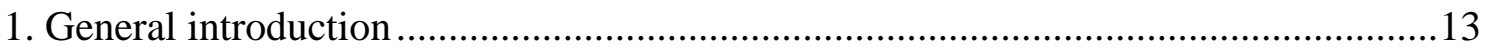

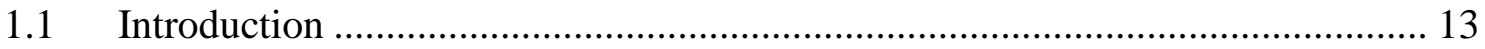

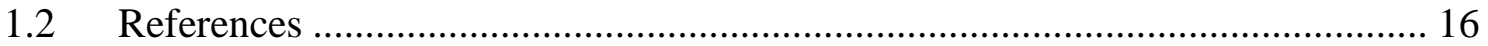

2. Chapter I - Main principles of forest and landscape restoration: a qualitative review 18

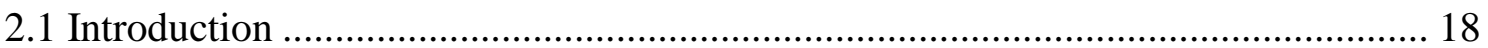

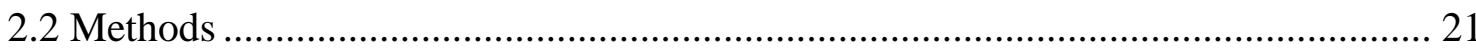

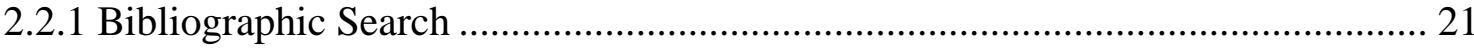

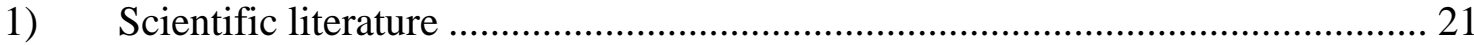

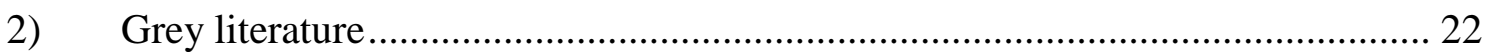

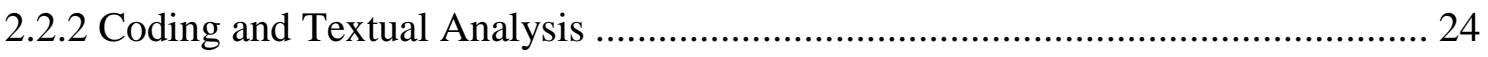

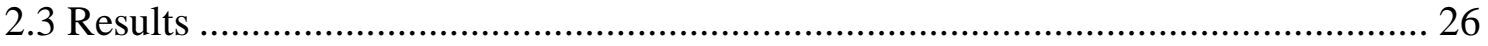

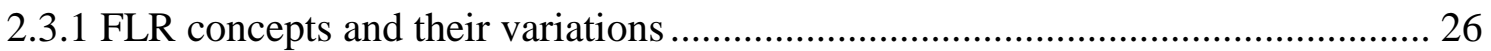

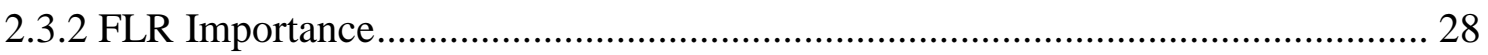

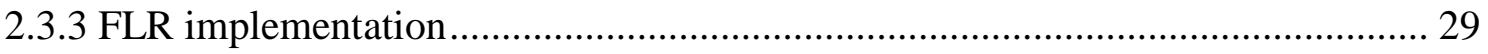

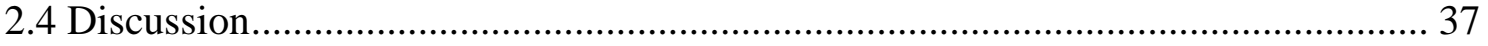

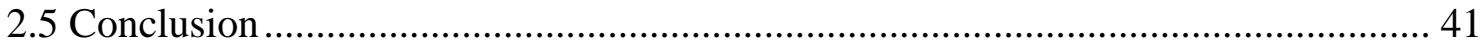

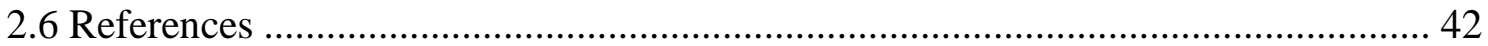

3. Chapter II - What Is Needed To Implement a Forest And Landscape Restoration Intervention? Development of a Socioeconomic Standard ..........................................50

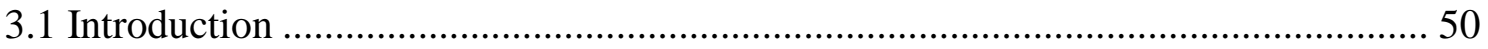

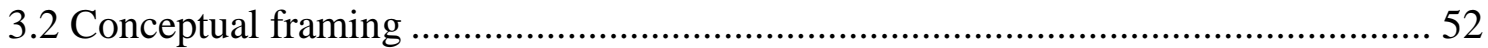

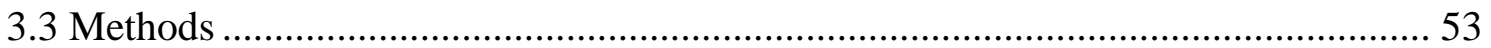

3.3.1 Development of the socioeconomic standardisation framework......................... 53

3.3.2 Development of interview protocols models ..................................................... 54

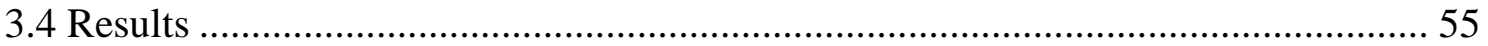

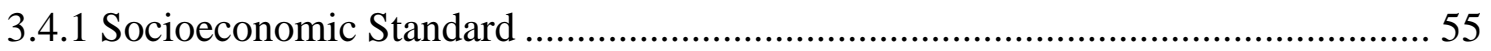

3.4.2 Interview Protocols Models ............................................................................. 79

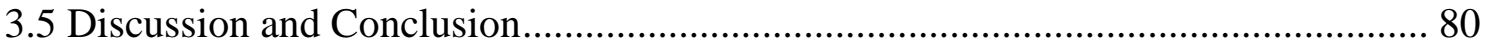

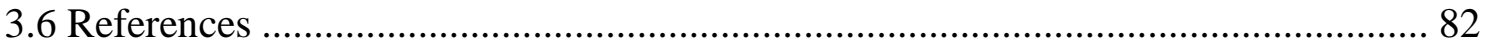

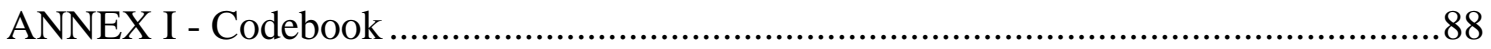

ANNEX II - Interview Protocol (Project Managers) ......................................................99 
ANNEX III - Interview Protocol (Participants) ..................................................... 129

ANNEX IV - Interview Protocol (Non-Participants) ............................................... 151 


\section{GENERAL INTRODUCTION}

\subsection{Introduction}

Interest in Restoration Ecology, i.e. the science of recovering those ecosystems that have been damaged, degraded or destroyed (SER, 2004), has been growing since the 1990s (YOUNG; PETERSEN; CLARY, 2005). Yet restoration has consequences beyond those affecting the natural components of the environment, as these initiatives can lead to socioeconomic and livelihood impacts on the inhabiting human populations (ARONSON et al., 2010). Despite that, more attention has traditionally been given to the ecological and environmental aspects of these initiatives, whereas the human dimensions of restoration have often been neglected (ROCCO, 2013).

More recently, however, the popularity gains of Restoration Ecology have been accompanied by a change in approach, from the original focus on Ecology as a science, to a holistic line of action that integrates the socioeconomic dimensions of restoration (WORTLEY; HERO; HOWES, 2013). Additionally, there has been a change in involved actors, with a growing interest in restoration outside academia, such as among civil society organisations, as well as the economic and public policy sectors (DELGADO; WOLOSIN; PURVIS, 2015).

This novel approach entitled Forest and Landscape Restoration (FLR) that arose in 2000 (CHAZDON et al., 2016), focuses on turning areas of degraded and unproductive lands across the globe into functional and multi-purpose landscapes, including but not being limited to restored ecosystems such as forests (LAESTADIUS et al., 2015). In so doing, it is expected that restoration will generate benefits for biodiversity and climate mitigation, and through the engagement of local stakeholders enhance restoration positive impacts to local livelihoods (GPFLR, 2008).

Several factors have driven changes in the restoration approach. One of them is the acknowledgement that, instead of promoting land use conflicts, the integration of ecosystem restoration in agricultural landscapes, such as through forest restoration, may be necessary to ensure agricultural productivity (DELGADO; WOLOSIN; PURVIS, 2015; CHAZDON; LAESTADIUS, 2016). Moreover, a growing number of governmental and non-governmental organisations recognise that, to achieve lasting results, restoration must be addressed at larger scales (DUDLEY; MANSOURIAN; VALLAURI, 2005), such as landscapes, which are more 
suited to handle a wide range of issues and needs (GPFLR, 2008). Within a global scenario of conflicting land use demands, FLR may also provide a strategy for conflict resolution because it promotes a more stable scenario that can be socially and environmentally beneficial as well as economically attractive (GPFLR, 2008).. FLR also offers a pragmatic way for countries to meet their international commitments (GPFLR, 2008), such as the recent international agreements on restoration targets and goals (e.g. Aichi Convention on Biological Diversity and Bonn Challenge) (CHAZDON et al., 2015).

Brazil accompanies this general trend as a consequence of the country's commitment to international treaties, including the Convention on Biological Diversity (CBD) that established the aforementioned Aichi Biodiversity Targets, The Convention on Wetlands of International Importance (RAMSAR), and the Bonn Challenge (MINISTÉRIO DO MEIO AMBIENTE, 2014). In order to implement the Aichi agreement, the Brazilian government established national biodiversity targets for the year 2020, through the publication of the CONABIO Resolution No. 6/2013. This resolution proposes to recover at least $15 \%$ of degraded ecosystem, within priority biogeographical regions, watersheds and most devastated ecoregions, including associated ecosystem services (e.g., water provision) (MINISTÉRIO DO MEIO AMBIENTE, 2014). Brazil has also established the Riparian Forest Restoration Project (PACTO), a collective and permanent initiative that involves more than 260 public and private organisations. Here, the goal is to restore 15 million hectares by 2050 , of which 1 million ha will contribute to the Bonn Challenge's goal (CHAZDON, 2008; MINISTÉRIO DO MEIO AMBIENTE, 2014). Moreover, FLR is seen as excellent approach to help achieving these international goals (ADAMS et al., 2016; GOUREVITCH et al., 2016).

However, since FLR is a novel approach, there is still a lack of consolidated knowledge basis for guiding its implementation. Despite some pioneer documents conceptualise the FLR approach based on the authors' own viewpoints (DUDLEY; MANSOURIAN; VALLAURI, 2005), there are no reviews or compilations about the theme. These studies could help in the identification of common FLR principles and so to fulfil a gap in the literature, besides helping in FLR initiatives implementation.

Moreover, the elaboration of tools that may help in the identification and implementation of FLR, such as standardization schemes, might serve as guidance to implement more successful initiatives, beyond helping in the standardization of concepts and activities. 
The main objective of this dissertation was to develop a socioeconomic standard for forest and landscape restoration (FLR) in the tropics. The specific objectives were:

- To identify which are the main principles that should be follow by an intervention to be considered Forest and Landscape Restoration (FLR), and

- $\quad$ To delineate a standardization framework appropriate to rural contexts that could be adopted in the implementation and evaluation of the socioeconomic impacts of FLR interventions.

This research is relevant both for scientific and project management aspects. In scientific terms, the project will contribute to consolidate information of the main principles for socio-economic aspects of forest and landscape restoration. As seen, despite the growing scientific interest in the area of restoration and evidence of both positive and negative impacts on social systems, there is still little consolidated knowledge about FLR. In addition, since FLR is a new approach, there are few studies about it and the information is dispersed not only in the scientific literature, but in documents produced by civil society organisations and governments.

In terms of policies, the project is relevant because, with the increase in the number of international agreements and the recent ratification by at least 30 of the 55 countries needed to implement the Paris agreement, an increase is expected in restoration investments. The effects of these projects will have to monitored not only in terms of their natural components, including the role in carbon emissions, but also in their socioeconomic component. Despite this, we still lack a common agreement on what FLR is and specially on the which are the main principles for socio-economic aspects of FLR interventions. A standardization framework may help on this endeavour as a guide to FLR implementation and monitoring, increasing the chances of success of the project as regards the impacts to the actors involved, as well as reducing the uncertainties regarding the progress of FLR interventions and their impacts on the actors involved also giving assurances to governments, NGOs and investors that the projects comply with the established objectives and the principles agreed. 


\subsection{References}

ADAMS, C.; RODRIGUES, S. T.; CALMON, M.; KUMAR, C. Impacts of large-scale forest restoration on socioeconomic status and local livelihoods: what we know and do not know. Biotropica, v. 48, n. 6, p. 731-744, 2016.

ARONSON, J., J. N. BlignAUT, S. J. Milton, D. LE MAITRE, K. J. ESLER, A. LIMOUZIN, C. FONTAINE, M. P. DE WIT, P. PRINSLOO, and L. VAN DER. Are Socioeconomic Benefits of Restoration Adequately Quantified? A Meta-analysis of Recent Papers (2000-2008) in Restoration Ecology and 12 Other Scientific Journals. Restoration Ecology 18:143-154. 2010.

CHAZDON, R. L. Beyond Deforestation: Restoring Forests and Ecosystem Services on Degraded Lands. Science 320:1458-1460. 2008.

CHAZDON, R. L., BRANCALION, P. H., LAESTADIUS, L., BENNETT-CURRY, A., BUCKINGHAM, K., KUMAR, C., WILSON, S. J. When is a forest a forest? Forest concepts and definitions in the era of forest and landscape restoration. Ambio 45:538-550. 2016.

CHAZDON, R. L., BRANCALION, P. H., LAESTADIUS, L, CALMON, M., KUMAR, C. A policy-driven knowledge agenda for global forest and landscape restoration. Conservation Letters 00:1-8. 2017.

DELGADO, C., WOLOSIN, M., PURVIS, N. Restoring and protecting agricultural and forest landscapes and increasing agricultural productivity. The New Climate Economy, London and Washington, DC. 2015.

DUDLEY, N., MANSOURIAN, S., VALLAURI, D. Forest landscape restoration in context. Pages 3-7 in Mansourian, S., Vallauri, D., and Dudley, N. Forest restoration in landscapes: beyond planting trees. Springer, New York, USA. 2005.

GPFLR - Global Partnership on Forest Landscape Restoration. Forest Landscape Restoration: See the Bigger Picture. International Union for Conservation Nature. 2008.

GOUREVITCH, J. D.; HAWTHORNE, P. L.; LKEELER, B.; BEATTY, C. R.; GREVE, M.; VERDONE, M. A. Optimizing investments in national-scale forest landscape restoration in Uganda to maximize multiple bene fi ts. Environmental Research Letters, v. 11, 2016.

LAESTADIUS, L., BUCKINGHAM, K., MAGINNNIS, S. \& SAINT-LAURENT, C. Back to Bonn and beyond: A history of forest landscape restoration and an outlook for the future. Unasylva. 2015.

MMA - Ministério do Meio Ambiente. Plano Nacional de Recuperação da Vegetação Nativa: versão preliminar. <www.mma.gov.br/images/arquivo/80049/Planaveg/PLANAVEG_20-11-14_copy.pdf>. 2014.

ROCCO, B. C. M. Avaliação ecológica e da percepção de proprietários rurais do processo de restauração de matas ciliares em Jaú e Saltinho - SP. 153 f. Dissertação 
(Mestrado em Ecologia Aplicada). Escola Superior de Agricultura "Luiz de Queiroz" Universidade de São Paulo, Piracicaba. 2013.

SER - Society for Ecological Restoration International. Princípios da SER Internacional sobre restauração ecológica. v. 2. 2004.

WORTLEY, L; HERO, J. M.; HOWES, M. Evaluating ecological restoration success: a review of the literature. Restoration Ecology 21:537-543. 2013.

YOUNG, T. P., PETERSEN, D. A., CLARY, J. J. The ecology of restoration: historical links, emerging issues and unexplored realms. Ecology Letters 8:662-673. 2005. 


\section{CHAPTER I - THE MAIN PRINCIPLES OF FOREST AND LANDSCAPE RESTORATION: A QUALITATIVE REVIEW}

\subsection{Introduction}

Forest and Landscape Restoration (FLR) is a novel approach of restoration, that arose in 2000, and that works at the landscape level allowing the continuity of different land uses (e.g. agriculture and primary forests) and the use different types of restoration interventions (e.g. agroforestry system and conservation). FLR aims to achieve ecological, economic and social outcomes and it was created to fulfill a gap in the restoration field, which was mainly focused on the ecological aspects while neglecting social aspects (URIBE et al., 2014).

The growing interest in restoration, in general, and FLR, in particular, is apparent in the scientific arena, although some authors also recognise there is still little emphasis on the human aspects of restoration when compared to the natural components (e.g. Aronson et al. 2010; Wortley et al. 2013). This is so despite the importance of understanding the human and socioeconomic dimensions of restoration, i.e. the way restoration actions are affected and affect the livelihoods and economy of human populations. Economic aspects, but above all, social, cultural and political aspects associated with restoration are only marginally addressed in the scientific literature (ROCCO, 2013).

In fact, a quantitative review of published studies until November 2012 that assessed the impacts of restoration to worldwide terrestrial habitats, estimated that $94 \%$ of the articles addressed ecological aspects (e.g. vegetation structure, ecological processes and fauna and flora diversity and abundance). In contrast, only $3.5 \%$ considered socioeconomic attributes (e.g. community engagement in restoration, psychological benefits, cost of restoration activity and job creation) (WORTLEY; HERO; HOWES, 2013). Likewise, another review of articles on terrestrial restoration, published in 13 journals from 2000 to 2008, aimed to identify the benefits of ecological restoration to society. The authors concluded we know little about it, because these benefits are frequently ignored or only superficially addressed in investigations (ARONSON et al., 2010). Both reviews thus highlight the need to expand our knowledge about the socioeconomic outcomes of restoration projects (ARONSON et al., 2010), as well as the need to monitor these aspects to assess restoration success (WORTLEY; HERO; HOWES, 2013). 
Although still limited, there is a recent slight increase in published articles addressing the socioeconomic aspects of restoration (ARONSON et al., 2010; BULLOCK et al., 2011). Wortley et al. (2013), for example, identified a steadily growth in publications over the last 28 years, with the majority of studies published between 2008 and 2012. Still, most studies focus on projects held in economically developed regions (ARONSON et al., 2010), such as North America (WORTLEY; HERO; HOWES, 2013), and neglect underdeveloped countries, where restoration is most needed due to higher deforestation and degradation rates (ARONSON et al., 2010).

Another limitation of current studies is their narrow scope, i.e. they may deal with a single human aspect, but neglect other socioeconomic impacts: some studies focus in resource investment or local community engagement in restoration (WORTLEY; HERO; HOWES, 2013); others evaluate the consequences to job generation and income provision (ARONSON et al., 2010; BRANCALION et al., 2010; WU; KIM; HURTEAU, 2011), or else the psychological outcomes, especially when restoration is implemented by volunteers (e.g. feeling part of a meaningful action, fascination with nature) (MILES; SULLIVAN; KUO, 1998; BRANCALION et al., 2014). This limited scope is problematic, because it hampers the opportunity to draw a general picture of the impacts of restoration to people. Ideally, a broad set of socioeconomic outcomes should be evaluated, such as for instance those suggested by Derr et al. (2005) and Egan and Estrada (2013).

Understanding the socioeconomic and livelihood impacts of restoration, ie, the impacts to the capabilities, material and social resources, and the activities made for means of life (CHAMBERS; CONWAY, 1991) is vital, especially when referring to FLR, because restoration almost never happens in empty spaces (HENNENMANN, 2013), and FLR in particular addresses not only forest restoration, but also rehabilitation of human-modified landscapes (CHAZDON et al., 2015). While restoration may have positive consequences to human communities, such as by improving locally needed ecosystem goods and services (CHAZDON et al., 2015), or increasing the access to jobs and income (see, e.g. Bendor et al. 2015), it may raise the opportunity costs of productive activities due to changes in land use and land access, especially in areas where land tenure is insecure (BULLOCK et al., 2011). Thus, research on the socioeconomic and livelihoods impacts of restoration interventions may provide valuable information to governments and restoration implementers to reinforce the positive impacts and mitigate negative outcomes. 
Second, social participation is a key driver of successful implementation and good performance in restoration projects (ROCCO, 2013), especially within landscape approaches. Without the active involvement of local inhabitants and other stakeholders, restoration may in fact not fully achieve the expected goals (REYES, 2011). To promote people's engagement in restoration initiatives, it is therefore important to understand why different segments of society participate (CHAZDON et al., 2015), as well as how knowledge about the positive and negative impacts can be used to motivate engagement (BLAY et al., 2008), increasing the chances of success (ARONSON et al., 2010).

Third, better knowledge about the impacts would likely reduce uncertainties to companies and investors willing to fund restoration projects (BRANCALION; CHAZDON, 2017).

Since FLR is a novel approach, there is still a lack of consolidated knowledge basis for guiding its implementation. Despite some pioneer documents conceptualise the FLR approach (e.g., DUDLEY et al., 2005; NEWTON et al., 2012), there has been no previous compilation of these documents that could support the identification of common principles and how they vary across different authors and stakeholders (e.g., researchers, NGOs, governments).

Because of that, this research aims the identification of the definition of main key concepts and FLR socioeconomic principles. Principles has a vast number of definitions, in general, can be "a basic idea or rule that explains or controls how something happens or works" (CAMBRIDGE DICTIONARY, 2017). In the sustainability domain, principles have been defined as " $[\mathrm{t}]$ hose elements with a global character that define a conceptual framework, and whose function is to serve as a basis or guideline for activities that contribute to the main objectives of sustainable management" (NUSSBAUM; SIMULA, 2005, p. 225). In forest certification, they are considered "the essential rules or elements of environmentally appropriate, socially beneficial and economically viable forest management" (FSC, 2015, p. 7). Based on these, we defined the FLR principles as the general rules representing the objectives that FLR projects must comply, in order to achieve a state of ecological integrity and human well-being within the forest landscape under restoration. This compilation could better address a consensual view of the inherent socioeconomic characteristics of FLR. 


\subsection{Methods}

To identify the main FLR principles, we conducted a systematic qualitative review, i.e. an explicit, repeatable and standardised procedures to identify, select, critically evaluate and code textual data (LITTRELL et al., 2008). We adopted Thematic Analysis, a technique that identifies, organises, analyses and reports patterns and themes in a selected qualitative dataset (BRAUN; CLARKE, 2008). The technique is useful for summarizing key features of a large data set, as it adopts a structured approach to handling data, although the flexibility of the method may result in inconsistencies and lack of coherence in deriving themes unless steps and epistemological positions are made explicit (NOWELL et al., 2017). The review was performed according to the following steps:

\subsubsection{Bibliographic Search}

The literature review consisted on a search of the published and indexed scientific articles and books chapters (section 1), as well as the grey literature, i.e. documents (e.g. books, brochures, policy briefs) produced by FLR programs and international nongovernmental organisations (NGOs) dedicated to advance the strategy worldwide (section 2). The search adopted a systematic approach, i.e. a procedure designed to answer specific questions using an explicit routine to identify, select and evaluate the literature (CASTRO, 2001), to increase the accuracy and unbiasedness of the review conclusions (WOODCOCK; PULLIN; KAISER, 2014), by avoiding the inclusion of only those studies that reinforce the author's opinions (AKOBENG, 2005).

\section{1) Scientific literature}

The bibliographic search advanced in three steps. To identify scientific articles that could provide information about FLR principles, we conducted a bibliographic search in two databases to guarantee that relevant articles were not ignored (Akobeng 2005; Castro 2001). Because they encompassed most journals where restoration articles are published, we used Scopus ${ }^{1}$ and Web of Science ${ }^{2}$. In Scopus, we selected documents of all types and searched for

\footnotetext{
${ }^{1}$ www.scopus.com
} 
the chosen terms in the title, abstract or keywords of the articles. In Web of Science, we chose the "Full Collection" option and searched the terms in the article's topic. In both databases, we included articles published from 1980 onwards until 2017.

The same keywords were used in both searches. The terms and their synonyms adopted were "forest" (OR woodland, trees, plantation, rainforest), "restoration" (OR revegetation, forestation, afforestation, rehabilitation) and landscape. We used boolean terms to make combinations, by putting two terms together (in quotation marks) and linking them with the third term and their synonyms. Three different types of word combinations were adopted: (i) "landscape restor*" AND forest OR woodland OR trees OR plantation OR rainforest; (ii) "forest restor*" AND landscape, (iii) "forest landscape" AND restoration OR revegetation OR forestation OR afforestation OR rehabilitation. These searches returned 1532 results.

In the second step, we used EPPI-Reviewer® v. $4^{3}$, a software developed to advance all types of systematic literature reviews. Within EPPI, we excluded document duplicities, ending up with 843 articles. We then screened these articles through reading their titles and abstracts, based in two inclusion criteria: (i) the article addressed FLR, and (ii) the article dealt, at least partially, with the socioeconomic aspects of restoration.

After screening, we pre-selected 118 articles, which were fully read, and then excluded those not related to FLR, resulting in 94 scientific documents selected (articles and book chapters).

\section{2) Grey literature}

Besides the scientific literature, we searched for documents published by NGOs and other organisations dedicated to FLR programs in three steps. We first identified the organisations involved in FLR. To do this, we asked three Restoration Ecology experts (two academic researchers and a NGO member) to list the main international organisations currently working with forest restoration, and we ended up with a preliminary list of 31 organisations.

Because we were interested in incorporating alternative views of the organisations instead of including all texts available, we adopted a standardized procedure to select a sample of texts. To reduce the subjectivity inherent in selecting texts within each one of the

\footnotetext{
${ }^{2}$ apps.webofknowledge.com

${ }^{3}$ http://eppi.ioe.ac.uk/cms/Default.aspx?alias=eppi.ioe.ac.uk/cms/er4
} 
organisation platforms, we adopted Google ${ }^{4}$ as the search engine across all organisation websites. We proceeded by searching in each of them the documents (textual information) available in the Portable Document Format (pdf), because this is the most usual format to make available texts of the type we were interested in. Thus, our search excluded information provided in other website locations, such as personal or institutional opinion information on the webpage bodies, videos, online magazine reports and some technical reports in other formats (e.g., doc, docx, xls and xlsx), which often corresponded to materials with an informal and unofficial description of the topic.

To do the search, first we repeated the procedure adopting the same term list used in the review of the scientific articles, and therefore: (i) "landscape restoration" forest OR woodland OR trees OR plantation OR rainforest, (ii) "forest restoration" landscape, (iii) "forest landscape" restoration OR revegetation OR forestation OR reforestation OR afforestation OR rehabilitation, but this search did not return useful documents in the results. So we entered in the Google search box using only two main terms, such as in the following example: ["forest landscape restoration" OR "forest and landscape restoration" site:www.wri.org filetype:pdf]. From the 31 organizations, only 19 (Table 1) presented useful documents based in our inclusion criteria.

We screened the research results of each organisation and only selected documents that were not: (i) annual project or organisation reports; (ii) description of projects for fundraising purposes; and (iii) lectures or presentations (e.g. slides). When several documents were available in a single organisation, we selected a maximum of three documents from each, so we ended up with 43 documents. The document was selected if it contained at least one of the following information: FLR concepts, what is needed for FLR projects, FLR results, what characterises a restoration project as FLR, and part of what guides FLR.

Table 1. FLR Organisations and documents available in the Google search.

\begin{tabular}{llcc}
\hline \multicolumn{1}{c}{ Organisation } & \multicolumn{1}{c}{ Website } & $\begin{array}{c}\text { Search results } \\
\text { (both terms) }\end{array}$ & $\begin{array}{c}\text { Useful in } \\
\text { the review }\end{array}$ \\
\hline Biodiversity International & $\begin{array}{l}\text { www.bioversityinternational. } \\
\text { org/ }\end{array}$ & 10 & 2 \\
\hline $\begin{array}{l}\text { CIFOR - Center for International } \\
\text { Forestry Research }\end{array}$ & www.cifor.org/ & 130 & 1 \\
\hline Commonland & www.commonland.com/ & 29 & 2 \\
\hline
\end{tabular}

\footnotetext{
${ }^{4}$ www.google.com
} 


\begin{tabular}{|c|c|c|c|}
\hline Organisation & Website & $\begin{array}{l}\text { Search results } \\
\text { (both terms) }\end{array}$ & $\begin{array}{l}\text { Useful in } \\
\text { the review }\end{array}$ \\
\hline $\begin{array}{l}\text { Ecoagriculture Partners (Landscapes } \\
\text { for People Food and Nature) }\end{array}$ & ecoagriculture.org/ & 10 & 1 \\
\hline $\begin{array}{l}\text { ELTI - Environmental Leadership \& } \\
\text { Training Initiative }\end{array}$ & elti.yale.edu/ & 35 & 2 \\
\hline $\begin{array}{l}\text { FAO - Food and Agriculture } \\
\text { Organization of the United Nations }\end{array}$ & www.fao.org/ & 727 & 3 \\
\hline GRN - Global Restoration Network & $\begin{array}{l}\text { www.globalrestorationnetwor } \\
\text { k.org }\end{array}$ & 10 & 3 \\
\hline GPFLR - Global Partnership on FLR & $\begin{array}{l}\text { www.forestlandscaperestorati } \\
\text { on.org/ }\end{array}$ & 169 & 3 \\
\hline ICRAF - World Agroforestry Centre & www.worldagroforestry.org/ & 85 & 3 \\
\hline Imazon & imazon.org.br/ & 5 & 1 \\
\hline $\begin{array}{l}\text { ITTO - International Tropical Timber } \\
\text { Organisation }\end{array}$ & www.itto.int/ & 51 & 2 \\
\hline $\begin{array}{l}\text { IUCN - International Union for } \\
\text { Conservation of Nature }\end{array}$ & www.iucn.org/ & 324 & 3 \\
\hline $\begin{array}{l}\text { IUFRO - International Union of Forest } \\
\text { Research Organisations }\end{array}$ & www.iufro.org/ & 231 & 3 \\
\hline Partners Reforestation Network & partners-rcn.org/ & 3 & 1 \\
\hline PROFOR - Program on Forests & www.profor.info/ & 32 & 3 \\
\hline $\begin{array}{l}\text { SER - Society for Ecological } \\
\text { Restoration }\end{array}$ & www.ser.org/ & 10 & 1 \\
\hline Tropenbos International & Www.tropenbos.org/ & 34 & 3 \\
\hline $\begin{array}{l}\text { USDA FS - United States Forest } \\
\text { Services Dpt of Agriculture }\end{array}$ & www.fs.fed.us/ & 754 & 3 \\
\hline WRI - World Resources Institute & www.wri.org/ & 56 & 3 \\
\hline TOTAL & & 2705 & 43 \\
\hline
\end{tabular}

\subsubsection{Coding and Textual Analysis}

After selecting relevant documents and articles, we conducted a systematic qualitative review to identify the main FLR principles. By a systematic and qualitative review, we mean the adoption of an explicit, repeatable and standardised procedures to identify, select, critically evaluate and code data from published studies and documents (LITTRELL J. H.; CORCORAN; PILLAI, 2008). Methods appropriate to systematically synthesise qualitative research, in general, and qualitative reviews, in particular, are less developed than those adopted with quantitative data, because of the particularities of qualitative data (e. g. they are not generalizable and are specific to particular contexts) and because the methods are more recent (began only in 1988) (DIXON-WOODS et al., 2006; THOMAS; HARDEN, 2008). 
Several methods and techniques to review qualitative data exist, such as: metaethnography, meta-study, metasynthesis (see THOMAS; HARDEN, 2008) and, more recently, Thematic Synthesis (see THOMAS; HARDEN, 2008), Thematic Analysis (see BRAUN; CLARKE, 2008) and Template Analysis (KING, 2004). In this study, we adopted Thematic Analysis, a technique that serves to identify, analyse and report patterns in the selected qualitative data (BRAUN; CLARKE, 2008). The method was applied in a five steps process, based on Braun et al (2008) and Thomas et al (2008) guidance. We departed from a list of central questions that we wanted to answer with the review. These central questions were divided into two main groups: (i) concepts and definitions and (ii) principles and criteria (Table 2).

Table 2. Central questions to the review

\section{Concepts and Definitions}

1. What is landscape or how is it conceptualised?

2. Which term is adopted to define FLR (e.g. forest and landscape restoration, forest landscape restoration)?

3. What is F LR or how is it conceptualised?

4. How and where FLR definitions vary (e.g., according to sector, scientific and civil society, other aspects)?

5. Why people argue FLR is important and necessary?

6. What types of interventions are considered as appropriate to FLR?

7. How scale is defined in different texts (e.g. multiple land uses, geographical)?

\section{Principles and Criteria}

1. What characterises a restoration project as FLR according to different views?

2. Is heterogeneity part of what guides FLR?

The second step consisted on gaining familiarity with the reviewed data through reading a sample of the whole data set before coding, i.e. attributing codes to identify that a certain section of the text is related to an issue important for the analysis at hand (KING, 2004). This initial reading was active, therefore attentive to patterns, similarities and meanings (Braun; Clarke, 2006). After that, based on the central questions and initial readings, our third step consisted on creating the codebook (Annex 1), which comprises the list of terms used to label portions of the text (e. g. definition of landscape, type of intervention) and to define characteristics of each text (e. g. year, type of author). 
Textual coding can be performed either manually or using a software (Braun; Clarke, 2006). We followed Thomas et al (2008) and adopted EPPI-Reviewer, a web-based software program for managing and data analysis. Text coding with EPPI-Reviewer consisted in reading the text, highlighting important fragments and assigning to them one or more codes. As qualitative analysis is an iterative process, when inadequacies in the initial codebook were perceived, we included or excluded codes, as well as changed their scope to a narrower or broader level (KING, 2004).

After all the reviewed documents were coded, we analysed the text fragments looking for repetitions, similarities and differences (see Ryan; Bernard, 2003). We then regrouped them hierarchically and sorted them into potential themes. At the end, we produced a diagram or map based on the relationship among codes, themes and different theme levels (Braun; Clarke, 2006). With these procedures, we advanced new analytical themes from the information in the original literature and generated concepts and understandings based on our judgement and ideas (THOMAS; HARDEN, 2008).

\subsection{Results}

We present our findings in the following order. We begin by exploring the definitions of the key FLR concepts, followed by the justification of FLR importance. We then present the socioeconomic principles of FLR and as well as the main actions to achieve those principles.

\subsubsection{FLR concepts and their variations}

There is not consensual term in the literature that addresses this restoration approach. Most authors (72\%) adopt the term Forest Landscape Restoration (104 documents), but other less used terms are Forest and Landscape Restoration (23; 16\%), Large-scale Forest Restoration (9, 6\%), Restoration of Forest Landscapes (4, 2\%), Forest Restoration in Landscapes $(2,1,4 \%)$ and Restoration of Forest and Landscape (1, 0,6\%). There are no apparent patterns in the use of these terms, neither according to author type or location of the 
publication. Even so, documents adopting Forest and Landscape Restoration are all recent publications (2013 - 2017), what might indicate a change in the term adoption.

The most often FLR definition adopted in the literature (36 documents) was proposed in 2000 by the WWF and IUCN, and refers to FLR as "a planned process that aims to regain ecological integrity and enhance human well-being in deforested or degraded forest landscapes" (LAESTADIUS et al., 2015, p. 14), or minor variations in these terms that do not affect its meaning. This definition was incorporated in scientific and non-scientific documents of different periods, including those recent.

Definitions adopted vary in a number of aspects, such as how: landscape is defined, scale is incorporated (temporal and geographical), and how the ecological dimension is considered.

The definition of landscape varies depending on the disciplinary viewpoints (SCHLAEPFER, 2005; VAN OOSTEN, 2013). For example, while ecologists might focus on the relevance of conserving large areas, thus highlighting the importance of the ecological matrix, geographers tend to emphasize the importance of anthropogenic actions responsible for increasing landscape complexity (VAN OOSTEN, 2013). Yet, authors agree that the landscape is a heterogeneous mosaic of different land uses, including primary and secondary vegetation of different types, anthropogenic land uses (e.g., agriculture), as well as degraded lands (LAMB; ERSKINE; PARROTTA, 2005; IANNI; GENELETTI, 2010; VAN OOSTEN, 2013; FAO; GLOBAL MECHANISM OF THE UNCCD, 2015), across large areas of land or a watershed (FAO; GLOBAL MECHANISM OF THE UNCCD, 2015). Some authors go beyond and emphasize the dynamism inherent to the landscape, classifying it as a humanenvironment interaction system (STANTURF et al., 2014; SABOGAL; BESACIER; MCGUIRE, 2015)

Studies tend to agree on how they address FLR scale. As regards the geographical scale, the landscape is often defined as a continuous area, smaller than an ecoregion, but larger than a single site (DUDLEY; MANSOURIAN; VALLAURI, 2005; PFUND; STADTMÜLLER, 2005; SAINT-LAURENT, 2005), which differs from its neighbors based on ecological, cultural and socioeconomic aspects (PFUND; STADTMÜLLER, 2005). As for the temporal scale, authors concur that FLR is a long-term process (HANSON et al., 2015; ADAMS et al., 2016), which aims to achieve a range of objectives that benefit both ecological and socioeconomic aspects of the landscape, through restoring forest functions, generating 
ecosystem services, and the management of trade-offs between alternative objectives (DUDLEY; MANSOURIAN; VALLAURI, 2005; BARROW, 2014).

While the idea of returning the landscape to its historical conditions is incorporated by few authors (e.g. EVAMY, ; ITTO, 2006), most of them explicitly state that FLR does not aim to restore the landscape into historical conditions (IUFRO, 2017) or even the past patterns of land uses (LAESTADIUS et al., 2011). Instead, FLR goes beyond just re-establishing forests in individual sites to restore a certain ecological attribute. To most studies, this attribute is ecological integrity, which might refer to "to an ecosystem composition, structure, and functional processes" (MANSOURIAN; VALLAURI, 2014, p. 2). Other publications, in turn, emphasize the concept of ecological functionality, i.e. "the goods, services and ecological processes that forests can provide at the broader landscape level, as opposed to solely promoting increased tree cover at a particular location" (MAGINNIS, 2005, p. 27). Thus, the aim is to improve forest functions to meet people's and environmental needs across the entire landscape (SAINT-LAURENT, 2005; ZHOU et al., 2008; LAESTADIUS et al., 2011).

To do that, different interventions are possible (e.g. agroforestry, tree planting, natural regeneration, forest fragments connection) (IUFRO; WORLD RESOURCES INSTITUTE, ) and participatory processes are welcomed (ITTO, 2006). Because of the latter, certain authors highlight the potential role of FLR in conflict resolution, because it works at the landscape level and deals with interactions between different land uses within the landscape (BARROW, 2014), such as natural fragments, cultivated areas, communities and areas of passive and active restoration (CHAZDON; LAESTADIUS, 2016).

\subsubsection{FLR Importance}

There are several reasons why FLR is considered important or a superior restoration approach to others. FLR is often proclaimed as superior to other restoration approaches because it may provide multiple benefits. Almost every document reviewed argues about FLR importance and mentions its positive ecological, economic and social outcomes. As for ecological benefits, FLR supposedly contributes to carbon sequestration and biodiversity conservation, as well as improvements in the provision of ecosystem goods and services, or water and soil protection (ITTO, 2006; BIODIVERSITY INTERNATIONAL, 2011; DIEDERICHSEN et al., 2017a; MANSOURIAN, 2017). 
In relation to economic benefits, studies manifest the positive outcomes to land productivity, job creation (ADAMS et al., 2016) and income, through Payments for Ecosystem Services, for example (SCHUYT, 2005). Social and livelihood benefits are also mentioned, such as improvements in human well-being and food security (DUDLEY, 2005a; CAUGHLIN; ELLIOTT; LICHSTEIN, 2016; CHAZDON et al., 2017), or the capacity to promote conflict resolution, by including local people in decision-making (HAMPSON et al., 2017), as well as the private sector. The involvement of actors from the private sector may represent a win-win solution, because it can advance better land-use practices, environmental agendas and compensates environmental impacts (CHAZDON et al., 2015)., while improving companies' reputation, image and relations (GUTIERREZ; KEIJZER, 2015a). Moreover, the private sector can supposedly provide resources to finance FLR projects, although only few articles address this issue (but see: GUTIERREZ; KEIJZER, 2015; BRANCALION; CHAZDON, 2017).

Because of its superiority, FLR is very often mentioned in the literature as an approach that might help achieve the growing number of international restoration goals. Almost $45 \%$ of the reviewed documents mentioned initiatives such as the Bonn Challenge, New York Declaration on Forests, Aichi Target 15 of the Convention of Biological Diversity, and the Reducing Emissions from Deforestation and Forest Degradation (REDD) (FAO; GLOBAL MECHANISM OF THE UNCCD, 2015; ADAMS et al., 2016; GOUREVITCH et al., 2016).

\subsubsection{FLR implementation}

Methods to plan FLR are among the most mentioned subjects. Authors reinforce the need to clarify which are objectives of the FLR project (MANSOURIAN et al. 2017), and to understand the ecological, socioeconomic and political contexts and available technical options (CHAZDON et al., 2015; MANSOURIAN, 2017a). Consequently, the project will also be able to establish how to achieve and assess the desired outcomes (BRANCALION; CHAZDON, 2017).

Planning FLR must encompass activities at short, medium and long-term (SCHLAEPFER, 2005; SNOOK 2016) and, because restoration is a dynamic process, schedules need periodic revision (HANSON et al., 2015). The main FLR implementation phases highlighted were: 


\subsubsection{Defining a landscape}

Reviewed articles suggest FLR implementation should begin by identifying the landscape, and a few published guidelines have provided guidelines on this. At the global scale, “The Global Partnership on Forest Landscape Restoration" (2011) has created a world's "map of opportunities", based on the available information (e.g. land cover, land use, population density and other aspects). This map identified landscapes with characteristics that, according to its creators, will likely increase the chances of restoration implementation. However, as Laestadius et al. (2011) emphasises, this map does not help with delimitation at the national or regional scales.

A few documents (e.g. IUCN 2014, 2017; KRISTJANSON, 2017) present another systematic approach entitled "Restoration Opportunities Assessment Methodology" (ROAM). Developed conjointly by the International Union for Conservation of Nature (IUCN) and the World Resources Institute (WRI), ROAM may help in the assessment of degradation types that need addressing, and to identify priority areas for restoration in the landscape (IUCN 2014, 2017; IUFRO 2017).

Less systematised suggestions include the consideration of geographical and land use characteristics, through the use of maps, GIS, mathematical models, remote sensing inputs (e.g. aerial photos), and field data collection (e.g. ground-based observations) (ORSI; GENELETTI, 2010; ORSI et al., 2011; CHADOURNE et al., 2012; URIBLE et al., 2014; HANSON et al., 2015; AGER, 2017). For example, in the Brazilian Amazon, the Uraim River catchment was identified as the priority area for restoration based on geographical aspects (e.g., high deforestation rate; area of riparian buffers deforested) and its importance to regional water supply (DIEDERICHSEN et al., 2017a).

Although systematic protocols may help, the reviewed studies emphasised that it is impossible to define a landscape scale applicable to all FLR projects (SABOGAL et al., 2015; MANSOURIAN, 2017). As the biological and human aspects need to be addressed case-bycase, the landscape scale will likely vary across FLR initiatives in different socio-ecological contexts (MANSOURIAN, 2017).

\subsubsection{Definition of FLR interventions}


The FLR allows a range of restoration strategies, both passive and active interventions. The choice of the type and spatial extent of restoration strategies depends on certain socioeconomic aspects of the landscape area, such as: the previous land use, the vicinity with natural remnants, human population density and distribution of settlements (FAO; GLOBAL MECHANISM OF THE UNCCD, 2015; CHAZDON; URIARTE, 2016). The most common strategies include: natural regeneration (site protection and fencing), management of secondary forests, subsistence agriculture, promotion of natural regeneration, restoration through plantations and agroforestry systems (ITTO, 2006; MANSOURIAN; VALLAURI, 2014).

Natural regeneration consists on passive restoration, when suitable conditions exist for restoration to occur naturally. This strategy is considered by certain authors as the most desirable solution, because of its simplicity and lower cost when compared with active interventions (MANSOURIAN; DUDLEY, 2005; HANSON; BUCKINGHAM; SEAN DEWITT, 2015)

In turn, restoration through tree or seed planting are active interventions (ORSI; GENELETTI, 2010; HANSON; BUCKINGHAM; SEAN DEWITT, 2015), which may be based on native or native-exotic mixed-species plantations (LAMB; ERSKINE; PARROTTA, 2005). On the one hand, authors frequently advocate that native species must be favoured (BERRAHMOUNI et al., 2015), as well as attention should be given to the quality and diversity of the genetic material used in planting (BERRAHMOUNI et al., 2015).

On the other hand, Hanson et al. (2015) highlight that fast-growing exotic species might be used as pioneer species to facilitate native species' growth under canopy cover. These exotic species can also generate short-term income, food or fuel to farmers (HANSON; BUCKINGHAM; SEAN DEWITT, 2015), therefore increasing people's support to restoration interventions.

In fact, four interventions are accounted in the reviewed literature as more directly linked with the generation of socioeconomic benefits. First, agroforestry systems, in a mix of trees that have use value (e.g. fodder, fuel wood, or timber) with agricultural crops that generate cash income to landowners (FAO, 2016; IUFRO, 2017). Second, agrosilvopastoral systems, mentioned by three authors, are indicated to restore pastoral lands, because planted trees help reduce the desiccation of grasses, while providing fodder and shade to the grazing livestock (IUFRO, 2017). Third, creating nurseries, because they are necessary both to 
produce tree seedlings and to economically involve local communities in the process of seedling production (SNOOK, 2016). Only two articles mention the use of beekeeping/apiculture as an appropriate intervention, although they do not describe the restoration process (KEENLEYSIDE et al., 2012; BUCK; BAILEY, 2014).

Although FLR is not only about planting trees and creating forested areas, only few authors mention the importance of implementing strategies that increase the sustainability of agricultural practices, or how restoration activities might contribute to that (IUCN, 2014; CHAZDON; URIARTE, 2016; IUFRO, 2017).

The design of FLR interventions must incorporate an adequate schedule that includes every necessary short, medium and long-term activity (SCHLAEPFER, 2005; SNOOK, 2016). More specifically, logistic aspects regarding the biological material, like the right moment to plant based on weather conditions (IUFRO, 2017) and the seedling production, that must be present desirable morphological qualities for the moment of planting activities (GREGORIO et al., 2017). Because restoration is a dynamic and long-term process, Hanson et al. (2015) advises that schedules are revised periodically.

\subsubsection{Definition of priority location for restoration strategies}

The choice of restoration strategies aforementioned is also directly linked with the definition of the location where those strategies will be implemented (FAO; GLOBAL MECHANISM OF THE UNCCD, 2015; CHAZDON; URIARTE, 2016). Dudley et al (2005) highlights the necessity to decide where forest is or is not needed, since FLR does not aim nor can restore forests in whole landscape, because of other land use claims. Therefore, It is necessary to identify the locations where interventions are more useful based on social, economic, political and ecological perspectives (DUDLEY; MANSOURIAN; VALLAURI, 2005; PFUND; STADTMÜLLER, 2005; MANSOURIAN et al., 2017).

The strategies chosen to be implemented will determine restoration effectiveness, economic costs and feasibility (ORSI; CHURCH; GENELETTI, 2011). Orsi et al (2011) present a report proposed by WCMC with guidelines for prioritizing forest restoration sites. This document suggests that forest restoration should be primarily directed towards areas: of original forest or woodland, now deforested; in close proximity to existing forests; rich in biodiversity, and locations with low population density. 
Moreover, places where ownership type and land tenure are mixed create a more complex situation to restoration than landscapes dominated by large properties with few owners. In contrast, Samsuri et al (2014) advocate that large landowners or those with high income levels will less likely participate of FLR initiatives, whereas low income people tend to join restoration practices to increase their income levels.

As previously noted, stakeholder interests must be considered in restoration decisions to ensure its long term sustainability and success (IUFRO, 2017). To allow that, the objectives of landowners should be taken into account in the choice of restoration areas; the goods, services and ecosystem functions that will be promoted, and the tree species they would like to plant (IUFRO, 2017).

FLR managers must identify areas consistent with restoration conditions that could improve functional outcomes. For instance, areas with high population density and fuelwood demand would benefit from agroforestry systems and local-level woodlots (IUCN, 2014; IUFRO, 2017). Identifying locations that are able to regenerate naturally is important, because this lowers restoration costs (IUFRO, 2017) and is best suited to areas with low opportunity costs for other land uses (URIARTE; CHAZDON, 2016).

For areas with forest remnants, FLR should promote conservation interventions, such as planting corridors to increase forest connectivity (IUFRO, 2017). Beyond that, restoration activities must aim to complement and enhance food production where it already happens and not convert natural forests into plantations (MINNEMEYER et al., 2011).

Even when the main objective is to restore ecological functions, restoration strategies are more likely to succeed if they incorporate the improvement of livelihood conditions and the provision of goods and services (ORSI; GENELETTI, 2010; IUFRO, 2017). In this case, agroforestry systems might be a good choice, because they fulfil both objectives (IUFRO, 2017).

Under the socioeconomic perspective, priority areas for FLR implementation include "unproductive or abandoned agricultural land, deforested areas converted to grasslands, brush lands, scrublands or barren areas, and degraded forests" (SABOGAL; BESACIER; MCGUIRE, 2015, p. 8)

As regard land tenure regulation, few articles mention that it facilitates FLR implementation (LAMB; ERSKINE; PARROTTA, 2005; MANSOURIAN, 2017), because 
the lack of safety associated with tenure might disincentive stakeholder engagement (IUFRO, 2017; MANSOURIAN, 2017).

We also identified few citations about the importance of environmental laws in stimulating or demanding that landholders implement restoration in their lands (ARONSON; ALEXANDER, 2013; CHAVEZ-TAFUR; ZAGT, 2014; DIEDERICHSEN et al., 2017b) and that companies compensate their activities' impacts (CHAZDON et al., 2017). For example, in Brazil, the Federal Law for Protection of Native Vegetation (Law 12.651/2012) requires, among other obligations, the restoration of degraded areas that should compose the Permanent Preservation Area (PPA) and Legal Reserve (LR) of the property (CHAVEZ-TAFUR; ZAGT, 2014; DIEDERICHSEN et al., 2017a).

\subsubsection{Monitoring and adaptive management}

The literature advises that socioeconomic (e.g. income, employment, well-being, food security) and ecological (e.g. forest structure, function, composition and connectivity) outcomes of FLR initiatives should be evaluated and monitored (DUDLEY, 2005b; SCHULTZ et al., 2012; ADAMS et al. 2016). Monitoring must be based on FLR objectives, and its quality and cost-efficiency depends on the incorporation of only the needed indicators at site and landscape scales and predicting, as much as possible, actions at different timescales (IUCN, 2014, SCHULTZ et al., 2014).

Examples of socioeconomic, ecological, financial and overall project aspects to monitor include those described in the Collaborative Forest Landscape Restoration Program (SCHULTZ et al., 2014; IUCN, 2017; IUFRO, 2017; FAO and Global Mechanism of the UNCCD, 2015). Such activities can be carried out not only by trained natural and social scientists, but also by local communities (IUCN, 2014; SACANDE et al., 2015).

Given the dynamic contexts, the long period needed for some restoration outcomes and the myriad of FLR activities, monitoring must be kept flexible to allow for adaptive management, learning by doing, and improving practices over time (ITTO, 2006; SAINTLAURENT, 2009b; DUDLEY; ALDRICH, 2007; APOSTOL; SHLISKY, 2012; NEWTON et al., 2012). 


\subsubsection{Human aspects}

The effect of restoration to people's income is one of the most assessed aspects in the reviewed literature (ADAMS et al. 2016). Several authors argue FLR can increase cash income through income from selling forest products (e.g, timber, fuelwood, non-timber forest products) and ecosystem services, as well as by enhancing employment opportunities (BARROW, 2014; FAO and Global Mechanism of the UNCCD, 2015; CHAZDON et al., 2017). In four drylands of Latin America, for instance, forest restoration increased cash income from US\$ 62 to US\$ 7,440 per hectare over a twenty-year period, through the sale of carbon, timber and non-timber forest products and tourism services (IUCN 2014).

Non-monetary benefits that improve people's perceived well-being, enhance food security and resilience have also been raised in the literature. For example, agroforestry and restoration may increase subsistence forest products and food security (REIJ; GARRITY, 2016). Well-being improvements can also arise from other non-material benefits associated with FLR interventions when landscape beauty, environmental quality or recreational opportunities are enhanced.

The literature raises the concern that FLR interventions have to ensure gender equality. There are few evidences that women's participation in restoration activities may provide them with more time to dedicate to other types of more beneficial activities, such as education, and to empower women and enhance their leadership (ADAMS et al., 2016).

\subsubsection{Human Capital}

The success of FLR projects also depends upon the level of local people's access to information and capacity building to restoration interventions (HAMPSON et al., 2017). Besides enhancing the probability of project success, investment in capacity-building increases employment and income earning opportunities for stakeholders beyond the project scope.

Another aspect raised by the literature is development of stakeholders' capacity of leadership and influencing policy; and the improvement of self-esteem and confidence of FLR participants due to activities, capacitation and socialization (ITTO 2006; CHADOURNE et al. 2012; ADAMS et al. 2016). 


\subsubsection{Social Capital}

Planning process must be based in a very participative decision-making approach which address the needs of local communities (BERRAHMOUNI et al., 2015, MANSOURIAN, 2017). Through workshops, meetings and other activities that promote integration of participants, it is necessary to discuss with stakeholders their objectives and needs and engage them in the processes of planning, implementing and managing FLR (URGENSON et al., 2017, VAN OOSTEN et al., 2014; SOUZA et al., 2016; PISTORIUS; FREIBERG, 2014; WALPOLE et al., 2017). ). In this sense, the project must also provide the inclusion process based on traditional knowledge in restoration activities, aiming the integration and sharing of knowledge among stakeholders (BARROW, 2014).

Mansourian (2017) highlights that the economic value shift of the landscape under restoration might generate conflicts, such as misuse of natural resources and inequalities for groups like women and vulnerable communities. Implementation of conflict resolution tools and strategies, like contracting mediators, negotiations and facilitator institutions may mitigate such conflicts (URGENSON et al., 2017).

External partners (e.g. companies, private owners, research institutions and NGOs) may be needed for technical improvement or to fill capacity gaps in FLR initiatives (DUDLEY; ALDRICH, 2007; BARR; SAYER, 2012). Those partnerships might be promoted by the public sector, that can incentive investment through the development of adequate regulations and legal frameworks (MCGUIRE, 2014). Barr et al. (2012), for example, mentions that in the Asia-Pacific region the national governments agencies, in partnership with multilateral and bilateral donor agencies, are able to promote large-scale tree-planting programs with a range of socioeconomic and ecological objectives.

\subsubsection{Institutional capital}

Institutional capital (i.e. informal and formal rules, laws and policies) drives land use decisions (ADAMS et al., 2016; FAO, 2016b; DIEDERICHSEN et al., 2017b). Legal compliance is considered essential to secure ecosystem conservation in private and public lands by encouraging ecosystem conservation and restoration (BUTLER et al., 2015; 
CHAZDON et al., 2017; MANSOURIAN, 2017). Yet we identified few mentions about the importance of environmental laws in stimulating or demanding that landholders restore landscapes (ARONSON; ALEXANDER, 2013; CHAVEZ-TAFUR; ZAGT, 2014; DIEDERICHSEN et al., 2017a) or that companies compensate their impacts (CHAZDON et al., 2017). Although environmental policies and law enforcement is considered crucial, some authors argue that forest agents should focus more on the provision of technical assistance and capacity-building to restoration, especially among small landowners and marginalised communities, making restoration knowledge reach those responsible for its implementation (BÁEZ et al., 2011; BERRAHMOUNI et al., 2015; BUTLER et al., 2015; ADAMS et al., 2016; DIEDERICHSEN et al., 2017b).

For the effective implementation of these instruments, the responsible organizations should assist local processes, by promoting an adequate governance structure, strengthening capacity of public institutions, engaging the private sector and markets, encouraging the equitable participation of stakeholders and, consequently, decentralizing decision-making and control to local groups (BERRAHMOUNI et al., 2015). Finally, organizations should be aligned with other activities in the landscape, implementing cross-sectoral consultation mechanisms to avoid conflicts during FLR development and maintain a structured supervision program (CHAVEZ-TAFUR; ZAGT, 2014; BUTLER et al., 2015; BUTLER et al., 2015).

\subsection{Discussion}

The last stage of the textual analysis consisted in create analytical themes: based on the information from literature and their matches and mismatches, we identified the main FLR Socioeconomic Principles (Table 3).

Table 3. FLR Socioeconomic Principles

\begin{tabular}{l|l}
\multicolumn{1}{l|}{ Principle } & \multicolumn{1}{|c}{ Description } \\
1. Landscape & $\begin{array}{l}\text { Work at landscape level, involving multiple land uses and multiple } \\
\text { stakeholders, implementing several types of restoration and conservation } \\
\text { strategies. }\end{array}$
\end{tabular}




\begin{tabular}{l|l}
$\begin{array}{l}\text { Legal and } \\
\text { normative } \\
\text { compliance }\end{array}$ & $\begin{array}{l}\text { The FLR Program must identify and define the laws and norms that it } \\
\text { corroborates and influences the Program. }\end{array}$ \\
$\begin{array}{l}\text { 3. Mitigation of } \\
\text { Inequalities }\end{array}$ & $\begin{array}{l}\text { Promote the mitigation of inequalities among people within the landscape } \\
\text { area. }\end{array}$ \\
$\begin{array}{l}\text { 4. Human } \\
\text { Resilience }\end{array}$ & $\begin{array}{l}\text { The FLR Program must help improve the human resilience through the } \\
\text { improvement of local livelihoods, as a result of the delivery of non-material } \\
\text { benefits, the provision of de natural resources (such as timber, fuel wood, } \\
\text { non-timber forest products) for self-consumption, ecosystem services and } \\
\text { market diversification. }\end{array}$ \\
5. Adaptive & $\begin{array}{l}\text { The monitoring process, should be used to identify the positive and negative } \\
\text { results, improve practices, enhance trust for financial investments and } \\
\text { identify and overcome challenges. }\end{array}$
\end{tabular}

\subsubsection{Project Principles}

With the codes of the topic Planning Process, we were able to create three new analytical themes, and so, identify the Principle "Landscape".

This Principle incorporates technics and methods that might be useful in the selection of landscape areas and also the ecological and socioeconomic characteristics that need to be considered when doing this selection (Figure 1). We identified that, since the definition of landscape varies, there is also a difficulty in the definition of how to select and delimitate the landscape area. Only few authors make it clear that the delimitation of landscape must happen case by case.

This Principle also arouse from the codification of information about the several types of restoration and conservation strategies that FLR initiatives can incorporate. There is an agreement in the literature about the use of a range of strategies in FLR initiatives, in order to achieve better ecological and socioeconomic results. Complementarily, the definition of priority areas is regarding the places where each of these interventions should be implemented, according to the ecological and socioeconomic demands and landscape characteristics. 

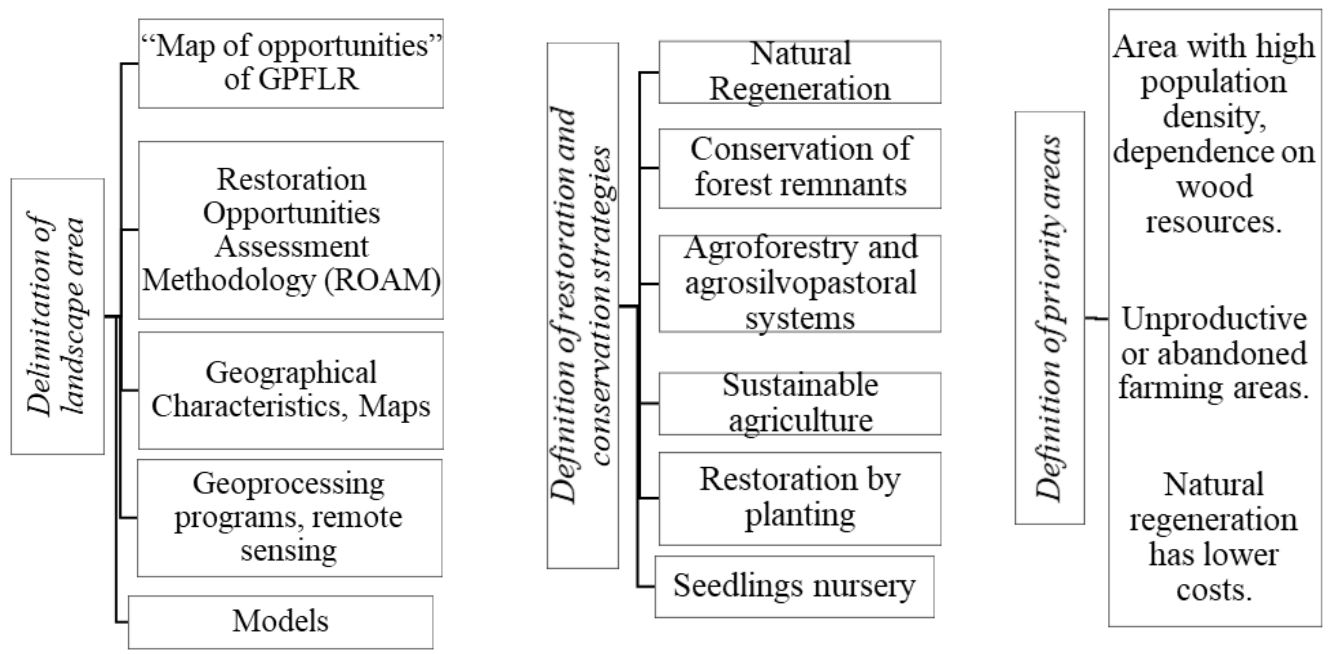

Figure 1 Subjects incorporated in "Landscape" Principle

About the legal and normative compliance, information was compiled from Institutional Capital codes. We expected that the literature would focus on the fact that FLR must also comply with legislation (e.g. environmental, labour, health and security legislation).

About the Principle Adaptive Management, although the literature presents relevant information about the importance of the implementation of monitoring, and it mentions the use of sufficient indicators to evaluate the local results of interventions, the literature does not reinforce the need to use indicators of the impact at the landscape level, neither for ecological and specially for socioeconomic outcomes. Another point is that the reviewed documents do not mention the need to evaluate people who have not actively participated in the FLR program but are located within the landscape area.

\subsubsection{Socioeconomic Principles}

The human and social capital presented information that made possible to identify principles of Mitigation of Inequalities (Figure 2) and Human Resilience (Figure 3).

Actions like participatory process is very often highlighted in the literature and should take place in every stage of the FLR program. It makes possible to identify that the social aspect is more present in FLR, and that social preferences and necessities must be part of restoration initiatives. 


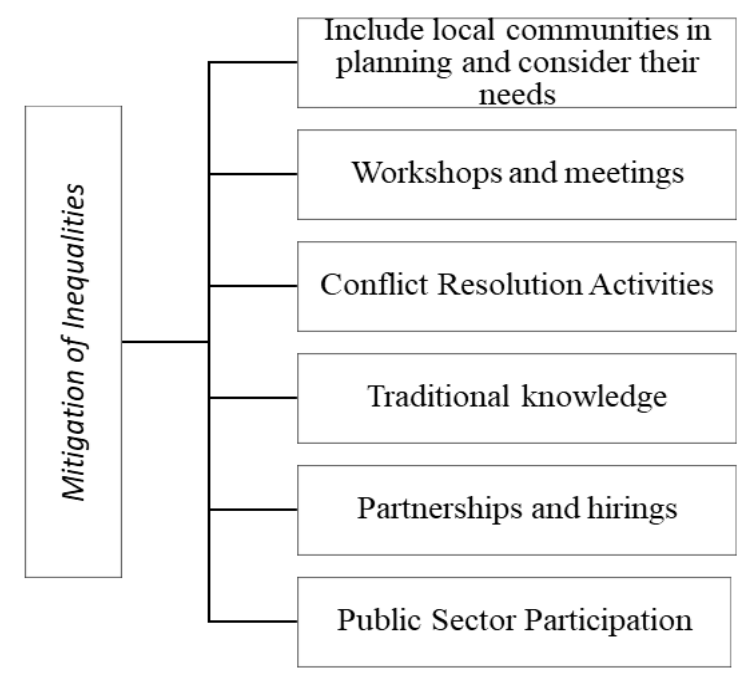

Figure 2 Subjects incorporated in "Mitigation of Inequalities" Principle

Almost every articles and document we reviewed mention the opportunity and the necessity to improve the livelihoods, but with few details about what is incorporated in that. Few authors mention the importance of gender equality or benefits for women and other vulnerable groups, thus this subject is neglected by the literature (ADAMS et al. 2016). However, the Restoration Opportunities Assessment Methodology (ROAM), includes considerations about increasing the participation of women and other less empowered groups (KRISTJANSON 2017).

The monetary aspect is very important, especially for including and guaranteeing human needs, and is also frequently mentioned as a FLR benefit. Addittionally, non-monetary returns are also very important for the livelihoods of local communities, but is less detailed in the literature. Another aspect involved here is the capacitation and training of local people to participate in the implementation of FLR, which also may increase their work opportunities within the current project and in other markets. 

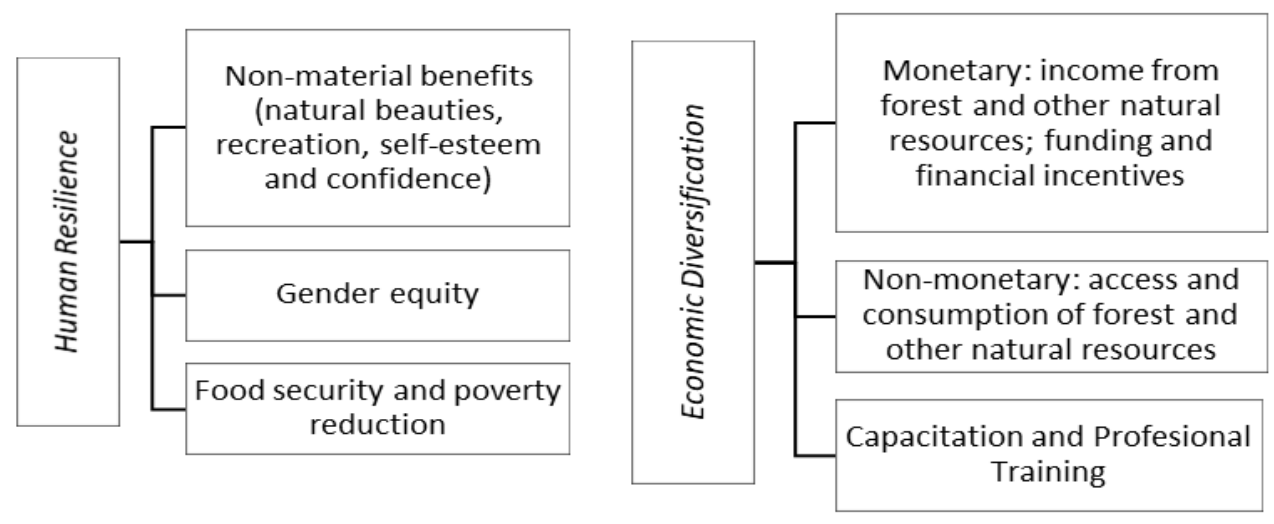

Figure 3 Subjects incorporated in "Human Resilience" Principle

\subsection{Conclusion}

Despite the undrepresentation of socioeconomic aspects in the scientific literature of ecological restoration, we could observe those aspects more often included in FLR initiatives. This may happen because of the evolution in the approach that FLR aims to achieve, integrating ecological with socioeconomic objectives.

At the end of the review we could observe that, despite few disagreements and some subjects neglected in the literature, the studies about FLR have been very consistent with each other.

The review results, however, might help to fulfil a gap in the restoration science and to guide future studies about FLR. This review may also serve as starting point for other tools that aims to improve FLR performance, like standardization frameworks. 


\subsection{References}

ADAMS, C.; RODRIGUES, S. T.; CALMON, M.; KUMAR, C. Impacts of large-scale forest restoration on socioeconomic status and local livelihoods: what we know and do not know. Biotropica, v. 48, n. 6, p. 731-744, 2016.

AGER, A. A.; VOGLER, K. C.; DAY, M. A.; BAILEY, J. D. Economic Opportunities and TradeOffs in Collaborative Forest Landscape Restoration. Ecological Economics, v. 136, p. 226-239, 2017. Disponível em: 〈http://dx.doi.org/10.1016/j.ecolecon.2017.01.001〉.

AKOBENG, A. K. Understanding systematic reviews and meta-analysis. Archives of Disease in Childhood, v. 90, n. 8, p. 845-848, 2005. Disponível em: <http://adc.bmj.com/cgi/doi/10.1136/adc.2004.058230>.

APOSTOL, D.; SHLISKY, A. Restoring Temperate Forests: A North American Perspective. 2. ed. [s.l: s.n.]

ARONSON, J.; ALEXANDER, S. Steering towards sustainability requires more ecological restoration. Natureza a Conservacao, v. 11, n. 2, p. 127-137, 2013.

ARONSON, J.; BLIGNAUT, J. N.; MILTON, S. J.; LE MAITRE, D.; ESLER, K. J.;

LIMOUZIN, A.; FONTAINE, C.; DE WIT, M. P.; MUGIDO, W.; PRINSLOO, P.; VAN DER ELST, L.; LEDERER, N. Are socioeconomic benefits of restoration adequately quantified? a meta-analysis of recent papers (2000-2008) in restoration ecology and 12 other scientific journals. Restoration Ecology, v. 18, n. 2, p. 143-154, 2010.

BARR, C. M.; SAYER, J. A. The political economy of reforestation and forest restoration in Asia-Pacific: Critical issues for REDD+. Biological Conservation, v. 154, p. 9-19, 2012.

BARROW, E. 300,000 hectares restored in Shinyanga, Tanzania - but what did it really take to achieve this restoration? S.a.P.I.En.S [Online], v. 7, n. 2, p. 1-8, 2014. Disponível em: $<$ http://sapiens.revues.org/1542>.

BENDOR, T.; LESTER, T. W.; LIVENGOOD, A.; DAVIS, A.; YONAVJAK, L. Estimating the size and impact of the ecological restoration economy. PLoS ONE, v. 10, n. 6, p. 1-15, 2015.

BERRAHMOUNI, N.; PARFONDRY, M.; REGATO, P.; SARRE, A. Restoration of degraded forests and landscapes in drylands: Guidelines and way forward. Unasylva, v. 66, n. 245, p. 3741, 2015.

BIODIVERSITY INTERNATIONAL. Importance of genetic considerations in forest 41 landscape restoration. v. 501, n. 1131854, p. 2, 2011.

BRANCALION, P. H. S.; CARDOZO, I. V.; CAMATTA, A.; ARONSON, J.; RODRIGUES, R. R. Cultural ecosystem services and popular perceptions of the benefits of an ecological restoration project in the Brazilian Atlantic Forest. Restoration Ecology, v. 22, n. 1, p. 65-71, 2014.

BRANCALION, P. H. S.; CHAZDON, R. L. Beyond hectares: four principles to guide reforestation in the context of tropical forest and landscape restoration. Restoration Ecology, v. 25, n. 4, p. 491-496, 2017. 
BRANCALION, P. H. S.; RODRIGUES, R. R.; GANDOLFI, S.; KAGEYAMA, P. Y.; NAVE, A. G.; GANDARA, F. B.; BARBOSA, L. M.; TABARELLI, M. Instrumentos legais podem contribuir para a restauração de ... INSTRUMENTOS LEGAIS PODEM CONTRIBUIR PARA A RESTAURAÇÃO DE FLORESTAS TROPICAIS BIODIVERSAS 1. Revista Árvore, v. 34, n. 3, p. 455-470, 2010.

BRAUN, V.; CLARKE, V. Using thematic analysis in psychology. v. 887, n. January, 2008.

BUCK, L. E.; BAILEY, I. D. Managing for Resilience. Framing an integrated landscape approach for overcoming chronic food insecurity. Washington, DC: EcoAgriculture Partners on behalf of the Landscapes for People, Food and Nature Initiative, 2014.

BULLOCK, J. M.; ARONSON, J.; NEWTON, A. C.; PYWELL, R. F.; REY-BENAYAS, J. M. Restoration of ecosystem services and biodiversity: Conflicts and opportunities. Trends in Ecology and Evolution, v. 26, n. 10, p. 541-549, 2011.

CASTRO, A. A. Revisão Sistemática e Meta-análise. Metodologia.org, v. 3, n. 1, p. 1-11, 2001. Disponível em: <http://metodologia.org/wp-content/uploads/2010/08/meta1.PDF>.

CAUGHLIN, T. T.; ELLIOTT, S.; LICHSTEIN, J. W. When does seed limitation matter for scaling up reforestation from patches to landscapes? Ecological Applications, v. 26, n. 8, p. 2437-2448, 2016.

CHADOURNE, M. H.; CHO, S. H.; ROBERTS, R. K. Identifying Priority Areas for Forest Landscape Restoration to Protect Ridgelines and Hillsides: A Cost-Benefit Analysis. Canadian Journal of Agricultural Economics, v. 60, n. 2, p. 275-294, 2012.

CHAMBERS, R.; CONWAY, G. R. Sustainable rural livelihoods: pratical concepts for the 21st century. Ids Discussion Paper, v. 296, n. Brighton: Institute of Development Studies, p. 29, 1991. Disponível em: <http://opendocs.ids.ac.uk/opendocs/handle/123456789/775>.

CHAVEZ-TAFUR, J.; ZAGT, R. Towards productive landscapes. ETFRN News, n. 56, p. 224, 2014.

CHAZDON, R. L. Beyond Deforestation : Restoring Degraded Lands. Communities, v. 1458, n. 2008, p. 1458-1460, 2008. Disponível em: <http://www.ncbi.nlm.nih.gov/pubmed/18556551〉.

CHAZDON, R. L.; BRANCALION, P. H. S.; LAESTADIUS, L.; BENNETT-CURRY, A.; BUCKINGHAM, K.; KUMAR, C.; MOLL-ROCEK, J.; VIEIRA, I. C. G.; WILSON, S. J. When is a forest a forest? Forest concepts and definitions in the era of forest and landscape restoration. Ambio, v. 45, n. 5, p. 538-550, 2016. Disponível em: <http://link.springer.com/10.1007/s13280016-0772-y>.

CHAZDON, R. L.; BRANCALION, P. H. S.; LAMB, D.; LAESTADIUS, L.; CALMON, M.; KUMAR, C. A Policy-Driven Knowledge Agenda for Global Forest and Landscape Restoration. Conservation Letters, v. 10, n. 1, p. 125-132, 2015.

CHAZDON, R. L.; BRANCALION, P. H. S.; LAMB, D.; LAESTADIUS, L.; CALMON, M.; KUMAR, C. A Policy-Driven Knowledge Agenda for Global Forest and Landscape Restoration. Conservation Letters, v. 10, n. 1, p. 125-132, 2017. 
CHAZDON, R. L.; LAESTADIUS, L. Forest and landscape restoration: Toward a shared vision and vocabulary. American Journal of Botany, v. 103, n. 11, p. 1869-1871, 2016.

CHAZDON, R. L.; URIARTE, M. Natural regeneration in the context of large-scale forest and landscape restoration in the tropics. Biotropica, v. 48, n. 6, p. 709-715, 2016.

CHNG, S. K. Marketing and Communications Opportunities: How to Promote and Market Forest Landscape Restoration. In: MANSOURIAN, S.; VALLAURI, D.; DUDLEY, N. (Ed.). Forest Restoration in Landscapes. [s.l: s.n.]

DELGADO, C.; WOLOSIN, M.; PURVIS, N. Restoring and protecting agricultural and forest landscapes and increasing agricultural productivity. Working paper for Seizing the Global Opportunity: Partnerships for Better Growth and a Better Climate, p. 1-44, 2015. Disponível em: <http://2015.newclimateeconomy.report/wp-content/uploads/2015/12/NCErestoring-protecting-ag-forest-landscapes-increase-ag.pdf $>$.

DIEDERICHSEN, A.; GATTI, G.; NUNES, S.; PINTO, A. Diagnostic of Key Success Factors for Forest Landscape Restoration: Municipality of Paragominas and The State of Pará. [s.l: s.n.].

DIEDERICHSEN, A.; GATTI, G.; NUNES, S.; PINTO, A.; DIEDERICHSEN, A. Diagnostic of Key Success Factors for Forest Landscape Restoration Municipality of Paragominas and The State of Pará Authors : [s.l: s.n.]

DIXON-WOODS, M.; BONAS, S.; BOOTH, A.; JONES, D. R.; MILLER, T.; SUTTON, A. J.; SHAW, R. L.; SMITH, J. A.; YOUNG, B. How can systematic reviews incorporate qualitative research? A critical perspective. Qualitative Research, v. 6, n. 1, p. 27-44, 2006. Disponível em: <http://journals.sagepub.com/doi/10.1177/1468794106058867>.

DUDLEY, M. Forest landscape restoration: a national perspective of a global partnership. In: VELTHEIM, T.; PAJARI, B. (Ed.). Forest landscape restoration: a national perspective of a global partnership. 53. ed. [s.l: s.n.]p. 21-24.

DUDLEY, N. Case study: monitoring forest landscape restoration in Vietnam. In: MANSOURIAN, S., D. VALLAURI, AND N. D. (Ed.). Forest Restoration in Landscapes: Beyond Planting Trees. [s.l: s.n.]p. 157-158.

DUDLEY, N.; ALDRICH, M. Five years of implementing forest landscape restoration: lessons to date. [s.l: s.n.].

DUDLEY, N.; MANSOURIAN, S.; VALLAURI, D. Forest Landscape Restoration in context. In: MANSOURIAN, S.; VALLAURI, D.; DUDLEY, N. (Ed.). Forest Restoration in Landscapes: Beyond Planting Trees. [s.l: s.n.]

EVAMY, M. Ideas Transform Landscapes. [s.l: s.n.]. Disponível em: $\langle$ https://www.wri.org/sites/default/files/uploads/ideas_transform_landscapes_brochure.pdf>.

FAO. Forest landscape restoration for Asia-Pacific forests. p. 198, 2016.

FAO, F. and A. O.; UNCCD, G. M. of the. Sustainable financing for forest and landscape restoration: Opportunities, challenges, and the way forward. [s.l: s.n.] 
FAO; GLOBAL MECHANISM OF THE UNCCD. Sustainable financing for forest and landscape restoration: opportunities, challenges and the way forward. [s.l: s.n.].

GOUREVITCH, J. D.; HAWTHORNE, P. L.; LKEELER, B.; BEATTY, C. R.; GREVE, M.; VERDONE, M. A. Optimizing investments in national-scale forest landscape restoration in Uganda to maximize multiple bene fi ts. Environmental Research Letters, v. 11, 2016.

GREGORIO, N.; HERBOHN, J.; HARRISON, S.; PASA, A.; FERRAREN, A. Regulating the Quality of Seedlings for Forest Restoration: Lessons from the National Greening Program in the Philippines. Small-scale Forestry, v. 16, n. 1, p. 83-102, 2017.

GUTIERREZ, V.; KEIJZER, M.-N. Funding forest landscape restoration using a business-centred approach: an NGO's perspective. In: APPANAH, S.; SHONO, K.; DURST, P. B. (Ed.). Unasylva. [s.l: s.n.]66p. 52-63.

GUTIERREZ, V.; KEIJZER, M. N. Funding forest landscape restoration using a business-centred approach: an NGO's perspective. Unasylva, v. 66, n. 245, p. 99, 2015 b.

HAMPSON, K.; LECLAIR, M.; GEBRU, A.; NAKABUGO, L.; HUGGINS, C. "There is No Program Without Farmers": Interactive Radio for Forest Landscape Restoration in Mount Elgon Region, Uganda. Society \& Natural Resources, v. 30, n. 5, p. 642-657, 2017. Disponível em: <https://www.tandfonline.com/doi/full/10.1080/08941920.2016.1239148>.

HANSON, C.; BUCKINGHAM, K.; DEWITT, S.; LAESTADIUS, L. The Restoration Diagnostic: A Method for Developing Forest Landscape Restoration Strategies by Rapidly Assessing the Status of Key Success Factors. 2015.

HENNENMANN, I. The Opportunities for External Business Investments in Landscape Restoration. n. November, 2013.

IANNI, E.; GENELETTI, D. Applying the ecosystem approach to select priority areas for forest landscape restoration in the Yungas, northwestern Argentina. Environmental Management, v. 46, n. 5 , p. $748-760,2010$.

ITTO. Guidebook for the formulation of afforestation and reforestation projects under the clean development mechanism. v. 25, 2006.

IUCN. Forest landscape restoration potential and impacts. Arbovitae, v. 45, n. 45, p. 16, 2014.

IUCN. Forest landscape restoration: meeting national and international biodiversity commitments. ForestBrief, n. 18, 2017.

IUFRO. Implementing Forest Landscape Restoration: a practitioner's guide. [s.l: s.n.] IUFRO; WORLD RESOURCES INSTITUTE. Forest Landscape Restoration as a Strategy for Mitigating and Adapting to Climate Change Context. [s.d.]Disponível em: <https://www.iufro.org/download/file/18473/1304/flr-project-flyer_pdf/>.

KEENLEYSIDE, K.; DUDLEY, N.; CAIRNS, S.; HALL, C.; SUE STOLTON. Ecological Restoration for Protected Areas. [s.l: s.n.] 
KING, N. Using Templates in the Thematic Analysis of Tex. In: CASSELL, C.; SYMON, G. (Ed.). Essential Guide to Qualitative Methods in Organizational Research. [s.l: s.n.]p. 256270.

KRISTJANSON, P. TOOLS AND APPROACHES FOR ADDRESSING ISSUES RELATED TO FOREST LANDSCAPES ,. n. January, 2017.

LAESTADIUS, L.; BUCKINGHAM, K.; MAGINNIS, S.; SAINT-LAURENT, C. Before Bonn and beyond: the history and future of forest landscape restoration. Unasylva, v. 245, n. 66, p. 11$17,2015$.

LAESTADIUS, L.; MAGINNIS, S.; MINNEMEYER, S.; POTAPOV, P.; SAINT-LAURENT, C.; SIZER, N. Mapping opportunities for forest landscape restoration. Unasylva, v. 62, n. 238, p. 47-48, 2011.

LAMB, D.; ERSKINE, P.; PARROTTA, J. A. Restoration of Degraded Tropical Forest Landscapes. Science, v. 310, n. 5754, p. 1628-1632, 2005.

LITTRELL J. H.; CORCORAN, J.; PILLAI, V. Systematic reviews and meta-analysis. New York: Oxford University Press, 2008.

MAGINNIS, S. What is Forest Landscape Restoration? In: VELTHEIM, T.; PAJARI, B. (Ed.). Forest Landscape Restoration in Central and Northern Europe. [s.l: s.n.]p. 25-26.

MANSOURIAN, S. Understanding the Relationship between Governance and Forest Landscape Restoration. v. 14, n. 3, p. 267-278, 2017.

MANSOURIAN, S.; DUDLEY, N. Challenges for forest landscape restoration based on WWF's experience to date. In: MANSOURIAN, S.; VALLAURI, D.; DUDLEY, N. (Ed.). Forest Restoration in Landscapes: Beyond Planting Trees. [s.l: s.n.]

MANSOURIAN, S.; STANTURF, J. A.; DERKYI, M. A. A.; ENGEL, V. L. Forest Landscape Restoration: increasing the positive impacts of forest restoration or simply the area under tree cover? Restoration Ecology, v. 25, n. 2, p. 178-183, 2017.

MANSOURIAN, S.; VALLAURI, D. Forest restoration in landscapes: beyond planting trees. 2005.

MANSOURIAN, S.; VALLAURI, D. Restoring forest landscapes: Important lessons learnt. Environmental Management, v. 53, n. 2, p. 241-251, 2014.

MCGUIRE, D. Forest and landscape restoration Mechanism. [s.l: s.n.]

MCLAIN, R.; GUARIGUATA, M. R.; LAWRY, S. Implementing Forest Landscape Restoration Initiatives: Tenure, Governance, and Equity Considerations. [s.l: s.n.].

MILES, I.; SULLIVAN, W. C.; KUO, F. E. Ecological restoration volunteers: the benefits of participation. Urban Ecosystems, v. 2, p. 27-41, 1998.

MINISTÉRIO DO MEIO AMBIENTE. Plano Nacional de Recuperação da Vegetação Nativa PLANAVEG - Versão Preliminar. Journal of Seed Science, v. 2, p. 79, 2014. 
MINNEMEYER, S.; LAESTADIUS, L.; SIZER, N.; SAINT-LAURENT, C.; POTAPOV, P. A World of Opportunity for Forest and Landscape RestorationBonn Challenge: on forests, climate change, and biodiversity 2011. [s.l: s.n.]. Disponível em: <http://www.wri.org/sites/default/files/world_of_opportunity_brochure_2011-09.pdf>.

NEWTON, A. C.; DEL CASTILLO, R. F.; ECHEVERRÍA, C.; GENELETTI, D.; GONZÁLEZESPINOSA, M.; MALIZIA, L. R.; PREMOLI, A. C.; REY BENAYAS, J. M.; SMITHRAMÍREZ, C.; WILLIAMS-LINERA, G. Forest landscape restoration in the drylands of Latin America. Ecology and Society, v. 17, n. 1, 2012.

NUSSBAUM, R.; SIMULA, M. The forest certification handbook second edition. Earth Scan publication Ltd, London, 2005.

ORSI, F.; CHURCH, R. L.; GENELETTI, D. Restoring forest landscapes for biodiversity conservation and rural livelihoods: A spatial optimisation model. Environmental Modelling and

Software, v. 26, n. 12, p. 1622-1638, 2011. Available on: <http://dx.doi.org/10.1016/j.envsoft.2011.07.008>.

ORSI, F.; GENELETTI, D. Identifying priority areas for Forest Landscape Restoration in Chiapas (Mexico): an operational approach combining ecological and socioeconomic criteria. Landscape and Urban Planning, v. 94, n. 1, p. 20-30, 2010.

PFUND, J.-L.; STADTMÜLLER, T. Forest Landscape Restoration (FLR) Brief historical review: From Forest Restoration to Forest Landscape RestorationInfoResources Focus. [s.l: s.n.].

PISTORIUS, T.; FREIBERG, H. From target to implementation: Perspectives for the international governance of forest landscape restoration. Forests, v. 5, n. 3, p. 482-497, 2014.

REIJ, C.; GARRITY, D. Scaling up farmer-managed natural regeneration in Africa to restore degraded landscapes. Biotropica, v. 48, n. 6, p. 834-843, 2016.

ROCCO, B. C. M. Avaliação ecológica e da percepção de proprietários rurais do processo de restauração de matas ciliares em Jaú e Saltinho - SP. 2013.

SABOGAL, C.; BESACIER, C.; MCGUIRE, D. Forest and landscape restoration: Concepts, approaches and challenges for implementation. In: LAPSTUN, S. (Ed.). Unasylva. [s.l: s.n.]p. 310 .

SACANDE, M.; BERRAHMOUNI, N.; HARGREAVES, S. Community participation at the heart of Africa's Great Green Wall restoration model 1. Unasylva, v. 66, n. 245, p. 44, 2015.

SAINT-LAURENT, C. Optimizing synergies on forest landscape restoration between the Rio conventions and the UN forum on forests to deliver good value for implementers. Review of European Community and International Environmental Law, v. 14, n. 1, p. 39-49, 2005.

SAINT-LAURENT, C. The Global Partnership on Forest Landscape Restoration. [s.l: s.n.].

SCHLAEPFER, R. Ecosystem approach and ecosystem management as the fundaments of Forest Landscape Restoration Strategies. In: VELTHEIM, T.; PAJARI, B. (Ed.). Forest Landscape Restoration in Central and Northern Europe. [s.l: s.n.]p. 69-82. 
SCHUlTZ, C. A.; COELHO, D. L.; BEAM, R. D. Design and Governance of Multiparty Monitoring under the USDA Forest Service\&amp;\#39;s Collaborative Forest Landscape Restoration Program. Journal of Forestry, v. 112, n. 2, p. 198-206, 2014. Disponível em: <http://www.ingentaconnect.com/content/saf/jof/pre-prints/content-jof13070>.

SCHULTZ, C. A.; JEDD, T.; BEAM, R. D. The Collaborative Forest Landscape Restoration Program: A History and Overview of the First Projects. Journal of Forestry, v. 110, n. 7, p. 381391, 2012. Disponível em: <http://openurl.ingenta.com/content/xref?genre=article\&issn=0022$1201 \&$ volume $=110 \&$ issue $=7 \&$ spage $=381>$.

SCHUYT, K. Opportunities for Long-Term Financing of Forest Restoration in Landscapes. In: Forest Restoration in Landscapes: Beyond Planting Trees. [s.l: s.n.]p. 161.

SER, S. for E. R. Princípios da SER International sobre a restauração ecológica. SER, Society for Ecological Restoration International, p. 15, 2004. Disponível em: <http://www.ser.org/>.

SNOOK, L. Safeguarding Investments in Forest Ecosystem Restoration Safeguarding investments in forest ecosystem restoration Policy Brief. n. February, 2016.

SOUZA, S. E. X. F.; VIDAL, E.; CHAGAS, G. de F.; ELGAR, A. T.; BRANCALION, P. H. S. Ecological outcomes and livelihood benefits of community-managed agroforests and second growth forests in Southeast Brazil. Biotropica, v. 48, n. 6, p. 868-881, 2016.

STANTURF, J. A.; PALIK, B. J.; WILLIAMS, M. I.; DUMROESE, R. K.; MADSEN, P. Forest Restoration Paradigms. Journal of Sustainable Forestry, v. 33, n. SUP1, 2014.

THOMAS, J.; HARDEN, A. Methods for the thematic synthesis of qualitative research in systematic reviews. BMC Medical Research Methodology, v. 8, n. 1, p. 45, 2008. Disponível em: <http://bmcmedresmethodol.biomedcentral.com/articles/10.1186/1471-2288-8-45>.

U.S. FOREST SERVICE. Collaborative Forest Landscape Restoration Program: Forest Service Project Site Visits. [s.l: s.n.]. Disponível em: $<$ http://www.fs.fed.us/restoration/CFLRP/>.

URGENSON, L. S.; RYAN, C. M.; HALPERN, C. B.; BAKKER, J. D.; BELOTE, R. T.; FRANKLIN, J. F.; HAUGO, R. D.; NELSON, C. R.; WALTZ, A. E. M. Visions of Restoration in Fire-Adapted Forest Landscapes: Lessons from the Collaborative Forest Landscape Restoration Program. Environmental Management, v. 59, n. 2, p. 338-353, 2017. Disponível em: <http://dx.doi.org/10.1007/s00267-016-0791-2>.

URIARTE, M.; CHAZDON, R. L. Incorporating natural regeneration in forest landscape restoration in tropical regions: synthesis and key research gaps. Biotropica, v. 48, n. 6, p. 915924, 2016.

URIBE, D.; GENELETTI, D.; DEL CASTILLO, R. F.; ORSI, F. Integrating stakeholder preferences and GIS-based multicriteria analysis to identify forest landscape restoration priorities. Sustainability (Switzerland), v. 6, n. 2, p. 935-951, 2014.

VAN OOSTEN, C. Restoring Landscapes-Governing Place: A Learning Approach to Forest Landscape Restoration. Journal of Sustainable Forestry, v. 32, n. 7, p. 659-676, 2013. Disponível em: <http://www.tandfonline.com/doi/abs/10.1080/10549811.2013.818551>. 
VAN OOSTEN, C.; GUNARSO, P.; KOESOETJAHJO, I.; WIERSUM, F. Governing forest landscape restoration: Cases from Indonesia. Forests, v. 5, n. 6, p. 1143-1162, 2014.

WALPOLE, E. H.; TOMAN, E.; WILSON, R. S.; STIDHAM, M. Shared visions , future challenges : a case study of three Collaborative Forest Landscape Restoration Program locations. v. 22, n. 2, 2017.

WOODCOCK, P.; PULLIN, A. S.; KAISER, M. J. Evaluating and improving the reliability of evidence syntheses in conservation and environmental science: A methodology. Biological Conservation, v. 176, p. 54-62, 2014. Disponível em: $<$ http://dx.doi.org/10.1016/j.biocon.2014.04.020>.

WORTLEY, L.; HERO, J. M.; HOWES, M. Evaluating ecological restoration success: A review of the literature. Restoration Ecology, v. 21, n. 5, p. 537-543, 2013.

WU, T.; KIM, Y. S.; HURTEAU, M. D. Investing in Natural Capital: Using Economic Incentives to Overcome Barriers to Forest Restoration. Restoration Ecology, v. 19, n. 4, p. 441-445, 2011.

YOUNG, T. P.; PETERSEN, D. A.; CLARY, J. J. The ecology of restoration: Historical links, emerging issues and unexplored realms. Ecology Letters, v. 8, n. 6, p. 662-673, 2005.

ZHOU, P.; LUUKKANEN, O.; TOKOLA, T.; NIEMINEN, J. Vegetation Dynamics and Forest Landscape Restoration in the Upper Min River Watershed, Sichuan, China. v. 16, n. 2, p. 348$358,2008$. 


\section{CHAPTER II - WHAT IS NEEDED TO IMPLEMENT A FOREST AND LANDSCAPE RESTORATION INTERVENTION? DEVELOPMENT OF A SOCIOECONOMIC STANDARD}

\subsection{Introduction}

Interest in Restoration Ecology, i.e. the science of recovering damaged, degraded or destroyed ecosystems (SER, 2004), has grown since the 1990s (YOUNG; PETERSEN; CLARY, 2005). Yet restoration practices have consequences beyond those affecting the natural components of the environment, because these initiatives can lead to socioeconomic and livelihood impacts on the inhabiting human populations (ARONSON et al., 2010). Despite that, more attention has traditionally been given to the ecological and environmental aspects of restoration initiatives, whereas their human dimensions have often been neglected (ROCCO, 2013).

More recently, however, the popularity gains of Restoration Ecology have been accompanied by transformations in this approach. First, by a change in the original focus from Ecology as a science, to an holistic line of action that integrates the socioeconomic dimensions of restoration (WORTLEY; HERO; HOWES, 2013). Second, actors involved are also changing, because of a growing interest in restoration outside academia, such as among civil society organisations, as well as the economic and public policy sectors (DELGADO; WOLOSIN; PURVIS, 2015).

Born in the 2000s, the novel approach, entitled Forest and Landscape Restoration (FLR) (CHAZDON et al., 2016), focuses on turning areas of degraded and unproductive lands across the globe into functional and multi-purpose landscapes, including but not limited to restoring natural ecosystems, such as forests (LAESTADIUS et al., 2015). By expanding its goals, FLR proponents expect that restoration will generate multiple benefits; thus, not solely to biodiversity and climate mitigation, but also to local livelihoods through, for instance, stakeholder engagement (GPFLR, 2008).

However, due to FLR relative novelty, a consolidated knowledge basis for guiding its implementation is this missing. Although certain pioneer documents (E.G. DUDLEY, MANSOURIAN, \& VALLAURI, 2005) conceptualise the FLR approach, to our knowledge, no attempt has been done to identify which are the most agreed upon FLR principles and associated actions needed to implement it. This particularly important because this approach focuses on the landscape and aims to achieve multiple outcomes through adopting several 
intervention types. Thus, evaluating its effectiveness is a challenge (SAYER; CAMPBELL, 2004).

Thus, devising tools that may help identify, implement and verify FLR outcomes and its achieved goals should provide an important asset to implementers (FAO; GLOBAL MECHANISM OF THE UNCCD, 2015; GUTIERREZ; KEIJZER, 2015; CHAZDON; URIARTE, 2016; SNOOK, 2016). Among these, standardization schemes might serve as guidance on how to appropriately implement FLR initiatives, beyond building consistency in the use of concepts and in the portfolio of activities that can be adopted.

These standards, as defined by the International Organization for Standardization (ISO), are "documented agreements containing technical specifications or other precise criteria to be used consistently as rules, guidelines, or definitions of characteristics, to ensure that materials, products, processes and services are fit for their purpose" (UPTON \& BASS, 1995 p. 27). Usually, they are developed by non-state actors such as NGOs, industry associations and social groups (AULD; GULBRANDSEN; MCDERMOTT, 2008). When products or processes follow these pre-established rules, a certificate may be granted and then displayed.

Over time, adopting standards to guide planning, implementing and monitoring the socioeconomic aspects of FLR initiatives may help enhance the positive impacts of restoration.

Moreover, the possibility of verification, associated with certain standards, may attract more attention from investors to FLR, such as observed in similar initiatives (e.g. Clean Development Mechanism certified projects) (NIJNIK; HALDER, 2013). The rationale is that standards and validation may increase security to private investors, when they choose among alternatives to mitigate their own activity impacts.

Despite the likely benefits of implementing FLR based on standards, to our knowledge, there are still no proposals for schemes geared to guide the socioeconomic aspect of all FLR phases.

Although such a system could mirror frameworks and indicators adopted in other domains, for instance forestry certification, FLR presents daunting challenges. Above all, because a much larger variety of contexts is addressed (i.e., not only forests), which multiplies the challenges in establishing common standards and indicators.

To exemplify, forestry standards can help assess, with a particular set of indicators, the effects of an intervention on a limited scope of socioeconomic components. In the case of 
FLR, standards will have to evaluate the socioeconomic effects of interventions in natural forests but also in human modified landscape units. This therefore include multiple society attributes, including social and economic organisations.

This chapter is therefore a first attempt at delineating a standard. Specifically, we focus on the socioeconomic aspects of FLR projects, i.e. the impacts and outcomes of FLR on five forms of capital that encompass people's livelihoods: human, social, financial, natural and physical (DE HAAN, 2000).

To do so, we departed from the systematic review presented in Chapter I, made with scientific articles and other relevant documents about FLR. We combined this information with insights from certification theory, including monitoring protocol and socioeconomic indicators. We did so to devise a standard and core principles appropriate to the FLR scope.

Because monitoring is essential to identify if FLR programs have been appropriately planned and implemented, as well as generate the expected outcomes, we also developed interview protocols to be used in the program assessment. In so doing, we expect that the standard and interview protocols will help increase the socioeconomic success of FLR projects and attract more funders to these initiatives due a decrease in investors' perceived risk.

\subsection{Conceptual framing}

We developed the framework of socioeconomic standards for FLR initiatives composed by Principles, Criteria and Indicators, terms which may present different definitions according to the area they are being used.

Principles have numerous definitions but, in general, constitute "a basic idea or rule which explains or controls how something happens or works" (CAMBRIDGE DICTIONARY, 2017). In the sustainability domain, principles have been defined as " $t]$ hose elements with a global character that define a conceptual framework, and whose function is to serve as a basis or guideline for activities that contribute to the main objectives of sustainable management" (Nussbaum \& Simula, 2005, p. 225). In turn, forest certification considers

principles as "the essential rules or elements of environmentally appropriate, socially beneficial and economically viable forest management" (FSC, 2015, p. 7). 
Based on these insights, we defined the FLR socioeconomic principles as: the general rules representing the objectives that FLR projects must comply, in order to enhance human livelihoods within the forest landscape under restoration.

Criteria are generally defined as "a standard by which you judge, decide about, or deal with something" (CAMBRIDGE DICTIONARY, 2017). In the scientific literature, for instance in the energy sector, we might find the definition as "the conditions needed to achieve these tenets, and which help to define the indicators to be answered" (Diaz-chavez, 2014, p. 19). The definition in forest certification considers criteria as "a means of judging whether or not a Principle (of forest stewardship) has been fulfilled" (FSC, 2015, p. 21).

Based on these definitions, we define here criteria as the main conditions the restoration project must achieve in order to assess whether the principles are being fulfilled or not.

The same happens with indicators, which are classified as "a thing that indicates the state or level of something" (Oxford Living Dictionaries, 2017) or, more specifically, as "elements that can be described or measured quantitatively and qualitatively to evaluate, periodically, their trend and to verify the level of compliance with a specific aspect of a criterion" (Nussbaum \& Simula, 2005, p. 225). Within the FSC certification framework, indicators are adapted for each national context, while ensuring they are in accordance with general principles and criteria.

Based on these definitions, we established that indicators are the main elements that, with pre-defined factors, can be measured to determine the compliance with criteria and the underlying principles they represent.

\subsection{Methods}

We advanced our methods in two main steps, which involved the development of the standard framework itself and then the preparation of interview protocols to assess the process of implementation and monitoring the results of FLR programs. The application of these protocols will also serve to test the socioeconomic standard framework.

\subsubsection{Development of the socioeconomic standardisation framework}


The development of the socioeconomic standardisation framework departed from the systematic review of scientific articles and conservation organisation that work with FLR literature presented in Chapter I. From that review, we identified the main actions needed and the socioeconomic aspects that a FLR project should address, including the core principles appropriate to the FLR scope and the identification and adaption the most relevant indicators to be evaluated in such projects. To do so, after identifying the key aspects, we classified them into the categories of Principles, Criteria and Indicators, based on the definitions provided before.

Because the FLR literature on socioeconomic aspects still lacks detailed information that helps build a consistent standardisation framework, we complemented it with other particularities from documents and publications from two other sources. First, document regarding certification, we adopted the Forest Stewardship Council certification scheme (i.e., FSC-STD-BRA-01-2014), because although it focus on the forestry sector, at least partially, it addresses certain aspects and requirements applicable to FLR programs that are not very well described in the literature, such as the actions about legal compliance.

Second, we complemented the information using documents (i.e. Besseau, Graham, \& Christophersen, 2018; Buckingham, Ray, Stolle, \& Zoveda, 2017) from international organisations, indicated by two specialists from an international NGO that acts in the implementation of FLR. We did so because these documents were published after the selection of FLR literature selection for review and because it bring relevant information about the consolidation of FLR principles and monitoring and about socioeconomic aspects.

\subsubsection{Development of interview protocols models}

The second step involved the preparation of interview protocols to assess the outcomes of FLR to relevant stakeholders. Because FLR encompasses multiple land uses and properties, it also involves several types of actors. We therefore developed three interview protocols directed to: (i) FLR program managers; (ii) landscape inhabitants who participated in the restoration activities, and (iii) for people inserted in the landscape area under restoration but who did not participate in the restoration activities.

All the protocols models consisted of structured interviews, mainly with multiple choice questions, but also with a few open ended questions, particularly in the case of protocols to the managers. The questions were written as clearly and objectively as possible, 
and we avoided asking information that related to long-passed events to avoid recall bias and improve both accuracy and validity (BERNARD et al., 1984). When needed, we adopted units that were understandable by the interviewee, and we did not approach more than one theme per question (FOWLER, 1995). As regards the thematic parts and content of the questions, they were based on our devised indicators from the Socioeconomic Standardisation Framework, presented in the previous sections. They were, however, adapted depending on the actor interviewed, therefore the FLR program manager; the person responsible for deciding about restoration activities in the property, in case of landscape inhabitants who participated in restoration, and the household head or the person responsible for productive activities in those landscapes properties that did participate in restoration.

\subsection{Results}

Here we present the results divided in two parts. The first one presents the Socioeconomic Standard, detailing its composition and describing its components and how it could be implemented. In the second part we present the three models of Interview Protocols.

\subsubsection{Socioeconomic Standard}

The Socioeconomic Standardisation Framework that resulted from our analyses is composed of 5 principles, 10 criteria and 45 indicators (Table 4), hierarchically organized. Aspects included are organised into three main categories: (i) planning and implementation, (ii) expected outcomes and (iii) management and monitoring. 
Table 4. Socioeconomic Standardisation Framework

\begin{tabular}{|c|c|c|c|c|c|c|c|c|c|c|c|c|c|c|}
\hline \multirow[b]{2}{*}{$\begin{array}{c}\text { Category / } \\
\text { Title }\end{array}$} & \multirow[b]{2}{*}{ Description } & \multicolumn{3}{|c|}{ Spatial scale } & \multicolumn{3}{|c|}{ Time scale } & \multicolumn{6}{|c|}{ Stakeholders } & \multirow[b]{2}{*}{ References } \\
\hline & & 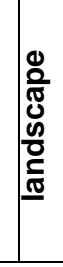 & 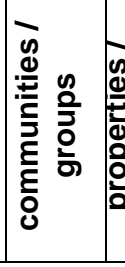 & 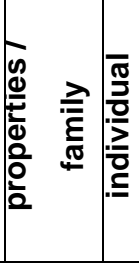 & 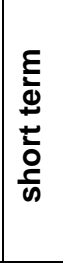 & 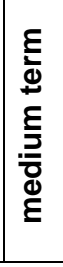 & 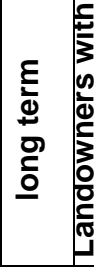 & 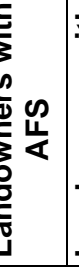 & 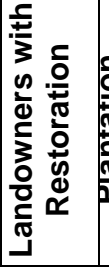 & 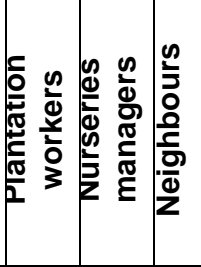 & 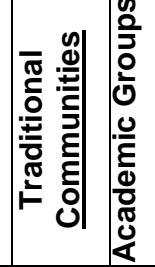 & 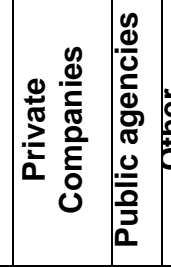 & 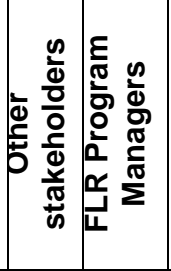 & \\
\hline \multicolumn{15}{|c|}{ Planning and Implementation } \\
\hline $\begin{array}{l}\text { Principle } \\
\text { Landscape }\end{array}$ & $\begin{array}{l}\text { Work at landscape level, involving } \\
\text { multiple land uses and multiple } \\
\text { stakeholders, implementing several } \\
\text { types of restoration and } \\
\text { conservation strategies. }\end{array}$ & & & & & & & & & & & & & \\
\hline $\begin{array}{l}\text { Criteria } \\
\text { Delimitation of } \\
\text { Landscape } \\
\text { area }\end{array}$ & $\begin{array}{l}\text { The landscape area to be restored } \\
\text { must be delimitated in order to select } \\
\text { an area that is bigger than a site and } \\
\text { smaller than an ecoregion, and that } \\
\text { encompasses multiple land uses and } \\
\text { multiple properties. It must be defined } \\
\text { case by case and adapted to the } \\
\text { region where the FLR program will be } \\
\text { implemented - We suggest the } \\
\text { development of a map that } \\
\text { encompasses all the needed } \\
\text { information to decision making, } \\
\text { described in the following Criteria and } \\
\text { Indicators. }\end{array}$ & & & & & & & & & & & & & $\begin{array}{l}\text { Lamb et al., 2005; } \\
\text { lanni and Geneletti, 2010; } \\
\text { van Oosten, 2013; } \\
\text { FAO and Global } \\
\text { Mechanism of the UNCCD, } \\
\text { 2015; } \\
\text { Dudley et al., 2005; } \\
\text { Pfund and Stadtmüller, } \\
\text { 2005; } \\
\text { Saint-laurent, 2005; } \\
\text { Hanson; Buckingham; } \\
\text { Dewitt, 2015. }\end{array}$ \\
\hline
\end{tabular}




\begin{tabular}{|c|c|c|c|c|c|c|c|c|c|c|c|c|c|c|c|c|c|c|c|}
\hline \multirow[b]{2}{*}{$\begin{array}{c}\text { Category / } \\
\text { Title }\end{array}$} & \multirow[b]{2}{*}{ Description } & \multicolumn{4}{|c|}{ Spatial scale } & \multicolumn{3}{|c|}{ Time scale } & \multicolumn{10}{|c|}{ Stakeholders } & \multirow[b]{2}{*}{ References } \\
\hline & & 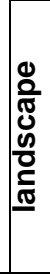 & 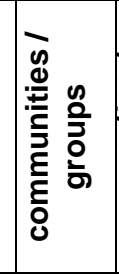 & 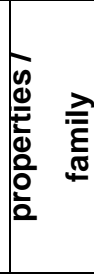 & $\frac{\overline{0}}{20}$ & 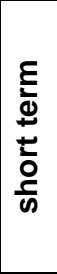 & 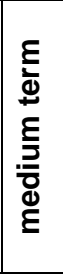 & $\begin{array}{l}\text { E } \\
\stackrel{5}{ \pm} \\
\text { O } \\
\text { 으 }\end{array}$ & 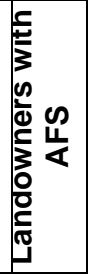 & 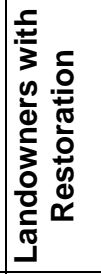 & 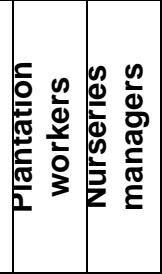 & 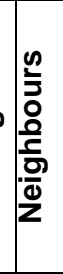 & 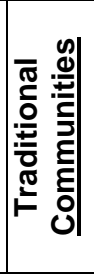 & 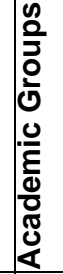 & 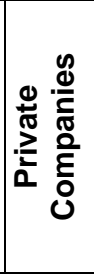 & 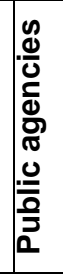 & 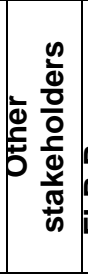 & 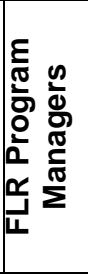 & \\
\hline $\begin{array}{l}\text { Indicator } \\
\text { Use of Maps } \\
\text { and } \\
\text { Geoprocessing } \\
\text { Programs }\end{array}$ & $\begin{array}{l}\text { The evaluation and area selection can } \\
\text { be made by using Geoprocessing } \\
\text { programs and maps. }\end{array}$ & & & & & & & & & & & & & & & & & & $\begin{array}{l}\text { Orsi and Geneletti, 2010; } \\
\text { Orsi et al, 2011; } \\
\text { Chadourne et al, 2012; } \\
\text { Uribe et al., 2014; } \\
\text { Hanson; Buckingham; } \\
\text { Dewitt, 2015. } \\
\text { Ager, } 2017\end{array}$ \\
\hline $\begin{array}{l}\text { Indicator } \\
\text { Geographical } \\
\text { Characteristics }\end{array}$ & $\begin{array}{l}\text { Consider geographical characteristics } \\
\text { (physical and socioeconomic aspects) } \\
\text { in the delimitation of landscape area. }\end{array}$ & & & & & & & & & & & & & & & & & & $\begin{array}{l}\text { Diederichsen et al. 2017; } \\
\text { Sabogal et al. 2015; } \\
\text { Mansourian 2017. }\end{array}$ \\
\hline \begin{tabular}{|l} 
Indicator \\
Level of \\
degradation
\end{tabular} & $\begin{array}{l}\text { Identify the level of degradation and } \\
\text { prioritise degraded areas to be } \\
\text { restored. }\end{array}$ & & & & & & & & & & & & & & & & & & $\begin{array}{l}\text { Buckingham; Ray; Stolle; } \\
\text { Zoveda, 2017; } \\
\text { IUCN, 2014; } \\
\text { IUFRO, 2017 }\end{array}$ \\
\hline $\begin{array}{l}\text { Indicator } \\
\text { Multiple Land } \\
\text { Uses }\end{array}$ & $\begin{array}{l}\text { Identify the multiple land uses within } \\
\text { the landscape area. }\end{array}$ & & & & & & & & & & & & & & & & & & $\begin{array}{l}\text { Lamb et al., 2005; } \\
\text { lanni and Geneletti, 2010; } \\
\text { van Oosten, 2013; } \\
\text { FAO and Global } \\
\text { Mechanism of the UNCCD, } \\
\text { 2015; }\end{array}$ \\
\hline
\end{tabular}




\begin{tabular}{|c|c|c|c|c|c|c|c|c|c|c|c|c|c|c|c|c|c|c|c|c|}
\hline \multirow[b]{2}{*}{$\begin{array}{l}\text { Category / } \\
\text { Title }\end{array}$} & \multirow[b]{2}{*}{ Description } & \multicolumn{4}{|c|}{ Spatial scale } & \multicolumn{3}{|c|}{ Time scale } & \multicolumn{11}{|c|}{ Stakeholders } & \multirow[b]{2}{*}{ References } \\
\hline & & 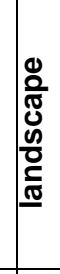 & 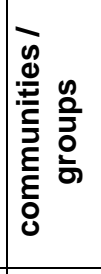 & 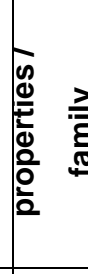 & 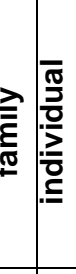 & $\begin{array}{l}\frac{E}{\Phi} \\
\stackrel{ \pm}{ \pm} \\
\frac{T}{\omega}\end{array}$ & 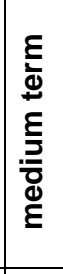 & 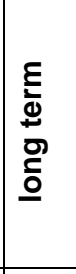 & 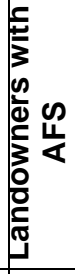 & 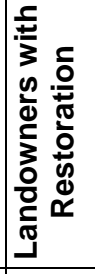 & 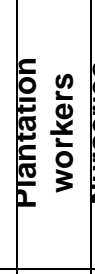 & 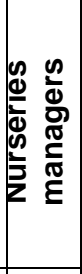 & 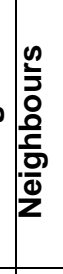 & 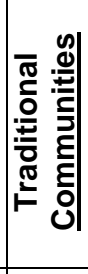 & 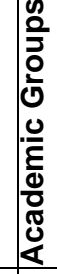 & 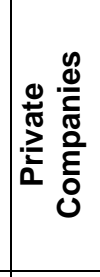 & 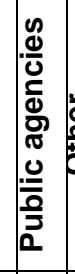 & 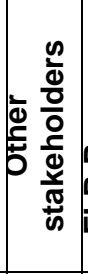 & 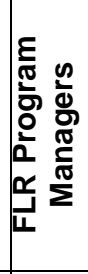 & \\
\hline $\begin{array}{l}\text { Indicator } \\
\text { Multiple } \\
\text { Properties }\end{array}$ & $\begin{array}{l}\text { Identify the multiple properties within } \\
\text { the landscape area. }\end{array}$ & & & & & & & & & & & & & & & & & & & $\begin{array}{l}\text { Lamb et al., 2005; } \\
\text { lanni and Geneletti, 2010; } \\
\text { van Oosten, 2013; } \\
\text { FAO and Global } \\
\text { Mechanism of the UNCCD, } \\
\text { 2015; }\end{array}$ \\
\hline Stakeholders & $\begin{array}{l}\text { Identify and characterise the } \\
\text { stakeholders that should be involved } \\
\text { in the FLR Program. }\end{array}$ & & & & & & & & & & & & & & & & & & & FSC, 2014; \\
\hline $\begin{array}{l}\text { Criteria } \\
\text { Definition of } \\
\text { Landscape } \\
\text { Strategies }\end{array}$ & $\begin{array}{l}\text { The type and spatial extent of active } \\
\text { and passive restoration strategies and } \\
\text { conservation strategies must be } \\
\text { selected in order to enhance positive } \\
\text { ecological and socioeconomic } \\
\text { outcomes. }\end{array}$ & & & & & & & & & & & & & & & & & & & $\begin{array}{l}\text { IUFRO and World } \\
\text { Resources Institute ; } \\
\text { ITTO, 2006; } \\
\text { Mansourian and Vallauri, } \\
2014\end{array}$ \\
\hline $\begin{array}{l}\text { Indicator } \\
\text { Passive and } \\
\text { Active } \\
\text { Restoration } \\
\text { Strategies }\end{array}$ & $\begin{array}{l}\text { To promote the implementation of } \\
\text { passive and active restoration } \\
\text { strategies. }\end{array}$ & & & & & & & & & & & & & & & & & & & $\begin{array}{l}\text { IUFRO and World } \\
\text { Resources Institute ; } \\
\text { ITTO, 2006; } \\
\text { Mansourian and Vallauri, } \\
2014\end{array}$ \\
\hline Indicator & $\begin{array}{l}\text { To prioritize the conservation of forest } \\
\text { remnants within landscape area }\end{array}$ & & & & & & & & & & & & & & & & & & & $\begin{array}{l}\text { Besseau; Graham; } \\
\text { Christophersen, 2018; } \\
\text { Budiharta et al,. 2014; }\end{array}$ \\
\hline
\end{tabular}




\begin{tabular}{|c|c|c|c|c|c|c|c|c|c|c|c|c|c|c|}
\hline \multirow[b]{2}{*}{$\begin{array}{l}\text { Category / } \\
\text { Title }\end{array}$} & \multirow[b]{2}{*}{ Description } & \multicolumn{3}{|c|}{ Spatial scale } & \multicolumn{3}{|c|}{ Time scale } & \multicolumn{6}{|c|}{ Stakeholders } & \multirow[b]{2}{*}{ References } \\
\hline & & 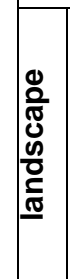 & 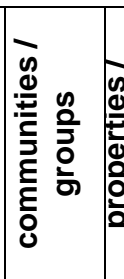 & 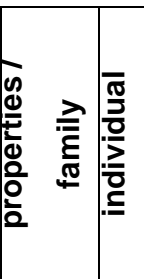 & 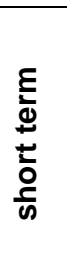 & 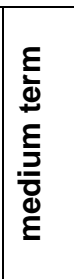 & 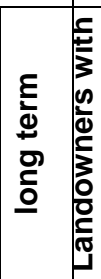 & 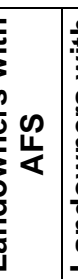 & 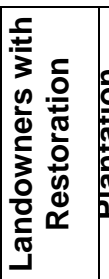 & 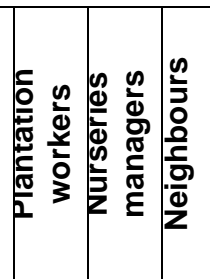 & 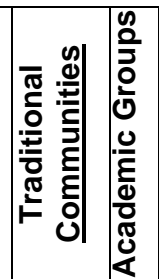 & 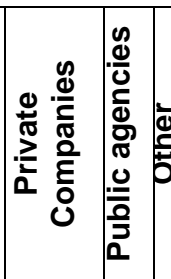 & 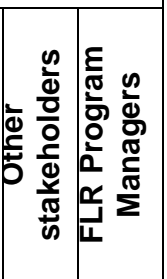 & \\
\hline Conservation & whenever possible. & & & & & & & & & & & & & Coello et al,. 2015 \\
\hline $\begin{array}{l}\text { Indicator } \\
\text { Natural } \\
\text { Regeneration }\end{array}$ & $\begin{array}{l}\text { The conduction of natural } \\
\text { regeneration must de prioritized in } \\
\text { order to simplify actions and to lower } \\
\text { costs. }\end{array}$ & & & & & & & & & & & & & $\begin{array}{l}\text { Mansourian and Dudley, } \\
\text { 2005; } \\
\text { Hanson et al., } 2015\end{array}$ \\
\hline $\begin{array}{l}\text { Indicator } \\
\text { Active } \\
\text { Restoration }\end{array}$ & $\begin{array}{l}\text { Active restoration strategies should be } \\
\text { implemented aiming different results } \\
\text { and configurations, like integrating } \\
\text { trees with other land uses, such as } \\
\text { agriculture, steppingstones, corridors } \\
\text { and enrichment of secondary forests. }\end{array}$ & & & & & & & & & & & & & $\begin{array}{l}\text { Lamb et al, 2005; } \\
\text { Budiharta et al., 2014; } \\
\text { Ashton et al., 2014; } \\
\text { IUFRO, } 2017\end{array}$ \\
\hline $\begin{array}{l}\text { Indicator } \\
\text { Strategies with } \\
\text { socioeconomic } \\
\text { returns }\end{array}$ & $\begin{array}{l}\text { To promote the implementation of } \\
\text { restoration and other support } \\
\text { strategies that bring socioeconomic } \\
\text { positive outcomes, beyond the } \\
\text { ecological benefits. }\end{array}$ & & & & & & & & & & & & & $\begin{array}{l}\text { FAO, 2016; } \\
\text { IUFRO, } 2017\end{array}$ \\
\hline $\begin{array}{l}\text { Indicator } \\
\text { AFS }\end{array}$ & $\begin{array}{l}\text { AFSs must be prioritized to generate } \\
\text { positive socioeconomic outcomes to } \\
\text { landowners, specially from small } \\
\text { properties that depend of land } \\
\text { production. }\end{array}$ & & & & & & & & & & & & & \begin{tabular}{|l|} 
FAO, 2016; \\
IUFRO, 2017
\end{tabular} \\
\hline
\end{tabular}




\begin{tabular}{|c|c|c|c|c|c|c|c|c|c|c|c|c|c|c|c|c|c|c|c|c|}
\hline \multirow[b]{2}{*}{$\begin{array}{c}\text { Category / } \\
\text { Title }\end{array}$} & \multirow[b]{2}{*}{ Description } & \multicolumn{4}{|c|}{ Spatial scale } & \multicolumn{3}{|c|}{ Time scale } & \multicolumn{11}{|c|}{ Stakeholders } & \multirow[b]{2}{*}{ References } \\
\hline & & 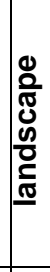 & 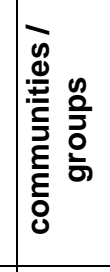 & 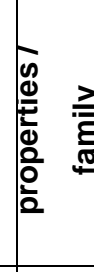 & 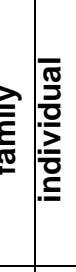 & \begin{tabular}{|l}
$\frac{\varepsilon}{2}$ \\
$\stackrel{ \pm}{ \pm}$ \\
$\frac{ \pm}{0}$ \\
$\frac{c}{\omega}$
\end{tabular} & 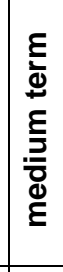 & 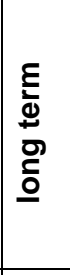 & 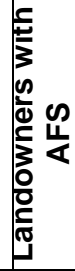 & 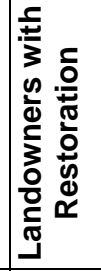 & 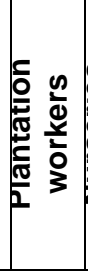 & 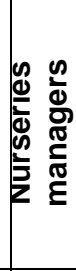 & 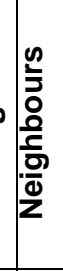 & 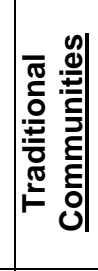 & 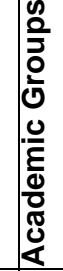 & 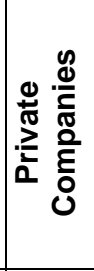 & 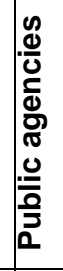 & 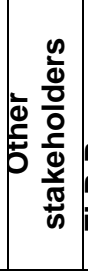 & 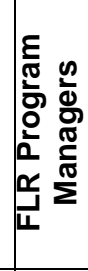 & \\
\hline $\begin{array}{l}\text { Indicator } \\
\text { Sustainable } \\
\text { Agriculture }\end{array}$ & $\begin{array}{l}\text { Define strategies that maintain current } \\
\text { agricultural lands within the landscape } \\
\text { but adopting more sustainable } \\
\text { approaches. }\end{array}$ & & & & & & & & & & & & & & & & & & & $\begin{array}{l}\text { lanni and Geneletti, 2010; } \\
\text { Aronson and Alexander, } \\
\text { 2013; } \\
\text { Sabogal et al., 2015; } \\
\text { Brancalion and Chazdon, } \\
2017\end{array}$ \\
\hline \multirow[t]{3}{*}{\begin{tabular}{|l} 
Indicator \\
Restoration \\
Supply Chain
\end{tabular}} & $\begin{array}{l}\text { To promote the creation and } \\
\text { maintenance of local supply chain, } \\
\text { such as seedling nurseries, plantation } \\
\text { services and other material providers. }\end{array}$ & & & & & & & & & & & & & & & & & & & $\begin{array}{l}\text { Adams et al., 2016; } \\
\text { Hampson et al., 2017 } \\
\text { Gregorio et al., } 2017\end{array}$ \\
\hline & $\begin{array}{l}\text { The seedlings used in the intervention } \\
\text { should be, mostly produced locally, by } \\
\text { qualified members of local community. }\end{array}$ & & & & & & & & & & & & & & & & & & & $\begin{array}{l}\text { Burgin et al., 2005; } \\
\text { Budiharta et al., 2014; } \\
\text { Coello et al., 2015; } \\
\text { Gregorio et al., } 2017\end{array}$ \\
\hline & $\begin{array}{l}\text { Workforce must be primarily } \\
\text { developed by members of the local } \\
\text { community. }\end{array}$ & & & & & & & & & & & & & & & & & & & $\begin{array}{l}\text { Hampson et al., 2017; } \\
\text { IUFRO, } 2017\end{array}$ \\
\hline
\end{tabular}




\begin{tabular}{|c|c|c|c|c|c|c|c|c|c|c|c|c|c|c|c|c|c|c|c|c|}
\hline \multirow[b]{2}{*}{$\begin{array}{c}\text { Category / } \\
\text { Title }\end{array}$} & \multirow[b]{2}{*}{ Description } & \multicolumn{4}{|c|}{ Spatial scale } & \multicolumn{3}{|c|}{ Time scale } & \multicolumn{11}{|c|}{ Stakeholders } & \multirow[b]{2}{*}{ References } \\
\hline & & 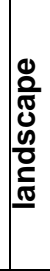 & 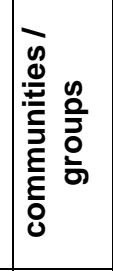 & 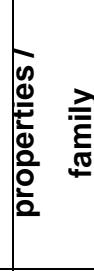 & 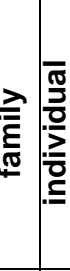 & 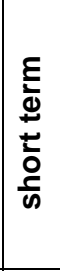 & 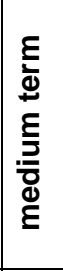 & 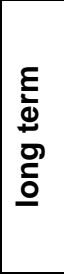 & 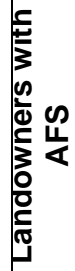 & 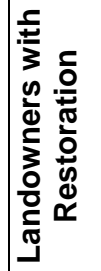 & 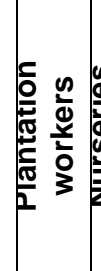 & 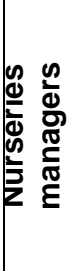 & 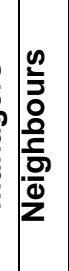 & 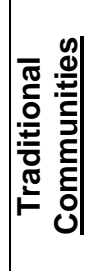 & 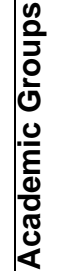 & 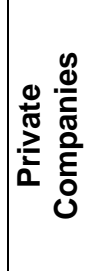 & 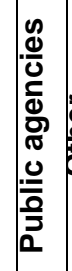 & 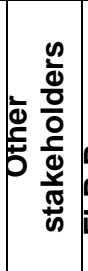 & 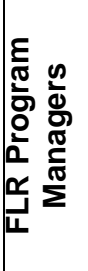 & \\
\hline \begin{tabular}{|l} 
Criteria \\
Definition of \\
priority areas
\end{tabular} & $\begin{array}{l}\text { The location where each type of } \\
\text { restoration or conservation strategy } \\
\text { will be implemented must be selected } \\
\text { based on social, economic, political } \\
\text { and ecological perspectives, in order } \\
\text { to conserve natural remnants, connect } \\
\text { fragments, restore degraded areas } \\
\text { and to meet stakeholders necessities } \\
\text { - We suggest the development of a } \\
\text { map that encompasses the } \\
\text { information of where each strategy } \\
\text { should be implemented. }\end{array}$ & & & & & & & & & & & & & & & & & & & $\begin{array}{l}\text { FAO; Global Mechanism of } \\
\text { the UNCCD, 2015; } \\
\text { Chazdon; Uriarte, } 2016 \\
\text { Pfund; Stadtmüller, 2005; } \\
\text { Mansourian et al., 2017; } \\
\text { Dudley et al., } 2005\end{array}$ \\
\hline $\begin{array}{l}\text { Indicator } \\
\text { Improve } \\
\text { Functional } \\
\text { Outcomes }\end{array}$ & $\begin{array}{l}\text { To Identify areas consistent with } \\
\text { restoration conditions that could } \\
\text { improve functional outcomes (such as } \\
\text { water provision, soil retention and } \\
\text { connectivity). }\end{array}$ & & & & & & & & & & & & & & & & & & & $\begin{array}{l}\text { Maginnis; Jackson, 2003; } \\
\text { ITTO, 2006; } \\
\text { Dudley et al., 2005; } \\
\text { Barrow, 2014 }\end{array}$ \\
\hline \begin{tabular}{|l} 
Indicator \\
Areas for \\
Passive \\
Restoration
\end{tabular} & $\begin{array}{l}\text { Based on the identification and } \\
\text { assessment of the areas within } \\
\text { landscape, it must be prioritized the } \\
\text { use of passive restoration intervention } \\
\text { where possible. }\end{array}$ & & & & & & & & & & & & & & & & & & & $\begin{array}{l}\text { Chazdon; Uriarte, 2016; } \\
\text { Mansourian; Dudley, 2005; } \\
\text { Hanson et al., } 2015\end{array}$ \\
\hline
\end{tabular}




\begin{tabular}{|c|c|c|c|c|c|c|c|c|c|c|c|c|c|c|c|c|c|c|c|c|}
\hline \multirow[b]{2}{*}{$\begin{array}{l}\text { Category / } \\
\text { Title }\end{array}$} & \multirow[b]{2}{*}{ Description } & \multicolumn{4}{|c|}{ Spatial scale } & \multicolumn{3}{|c|}{ Time scale } & \multicolumn{11}{|c|}{ Stakeholders } & \multirow[b]{2}{*}{ References } \\
\hline & & 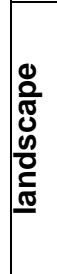 & 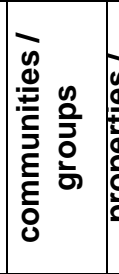 & 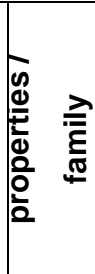 & 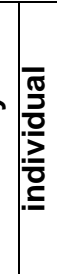 & 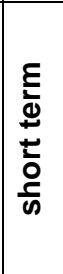 & 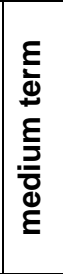 & 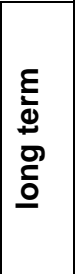 & 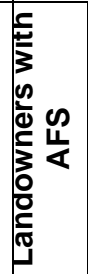 & 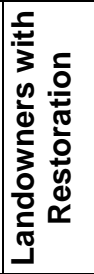 & 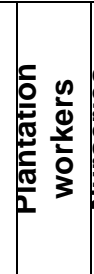 & 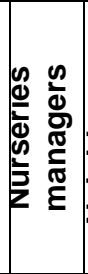 & 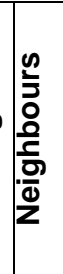 & 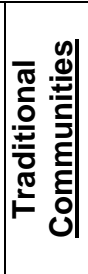 & 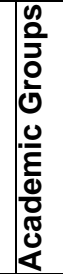 & 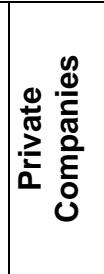 & 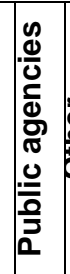 & 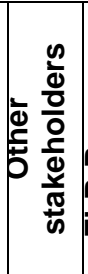 & 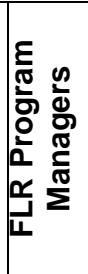 & \\
\hline $\begin{array}{l}\text { Indicator } \\
\text { Areas for } \\
\text { Conservation }\end{array}$ & $\begin{array}{l}\text { Based on the identification and } \\
\text { assessment of the areas within } \\
\text { landscape, define where conservation } \\
\text { must be implemented. }\end{array}$ & & & & & & & & & & & & & & & & & & & $\begin{array}{l}\text { Budiharta et al., } 2014 ; \\
\text { Coello et al., } 2015\end{array}$ \\
\hline $\begin{array}{l}\text { Indicator } \\
\text { Areas for } \\
\text { Active } \\
\text { Restoration }\end{array}$ & $\begin{array}{l}\text { Based on the identification and } \\
\text { assessment of the areas within } \\
\text { landscape, define where active } \\
\text { restoration must be implemented. }\end{array}$ & & & & & & & & & & & & & & & & & & & Dudley et al., 2005; \\
\hline Indicator & $\begin{array}{l}\text { Based on the identification and } \\
\text { assessment of the areas within } \\
\text { landscape, define where SAFs must } \\
\text { be implemented. }\end{array}$ & & & & & & & & & & & & & & & & & & & $\begin{array}{l}\text { FAO, 2016; } \\
\text { IUFRO, 2017 }\end{array}$ \\
\hline $\begin{array}{l}\text { Indicator } \\
\text { Stakeholder } \\
\text { interests and } \\
\text { needs }\end{array}$ & $\begin{array}{l}\text { Beyond ecological aspects, consider } \\
\text { stakeholders interests and needs to } \\
\text { define areas where each kind of } \\
\text { intervention should take place. }\end{array}$ & & & & & & & & & & & & & & & & & & & $\begin{array}{l}\text { Orsi; Geneletti, 2010; } \\
\text { IUFRO, 2017; } \\
\text { FSC, 2014; } \\
\text { Besseau; Graham; } \\
\text { Christophersen, 2018; }\end{array}$ \\
\hline \begin{tabular}{|l} 
Principle \\
Legal and \\
normative
\end{tabular} & $\begin{array}{l}\text { The FLR Program must identify and } \\
\text { define the laws and norms that it } \\
\text { corroborates and influences the } \\
\text { Program. }\end{array}$ & & & & & & & & & & & & & & & & & & & \\
\hline
\end{tabular}




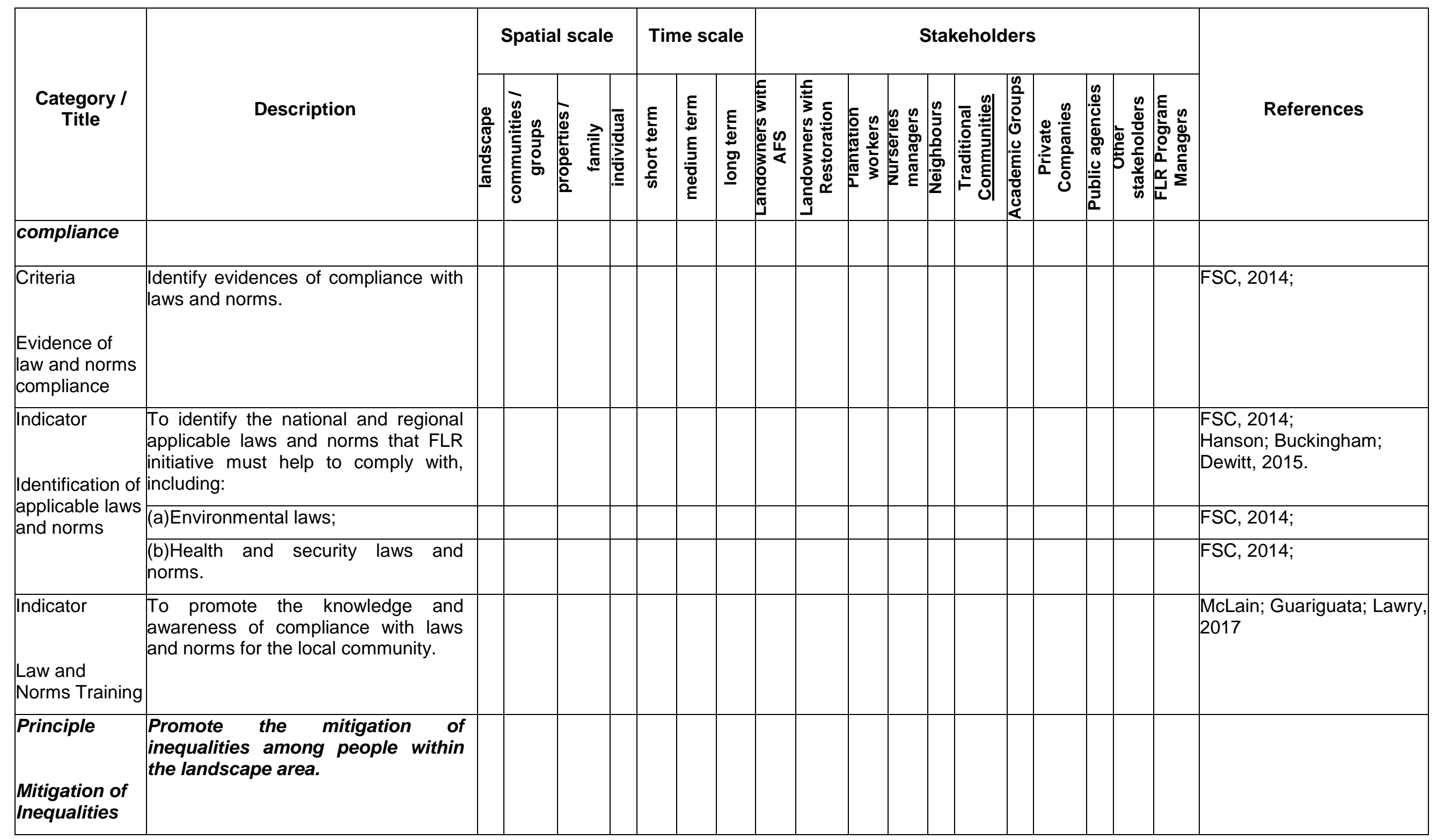




\begin{tabular}{|c|c|c|c|c|c|c|c|c|c|c|c|c|c|c|c|}
\hline \multirow[b]{2}{*}{$\begin{array}{l}\text { Category / } \\
\text { Title }\end{array}$} & \multirow[b]{2}{*}{ Description } & \multicolumn{3}{|c|}{ Spatial scale } & \multicolumn{3}{|c|}{ Time scale } & \multicolumn{7}{|c|}{ Stakeholders } & \multirow[b]{2}{*}{ References } \\
\hline & & 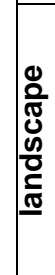 & 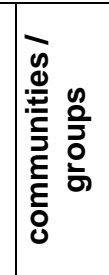 & 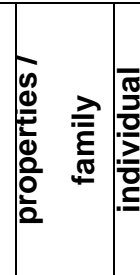 & 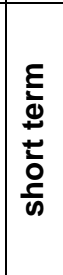 & 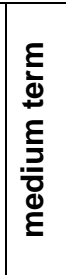 & 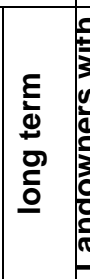 & 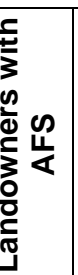 & 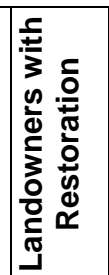 & 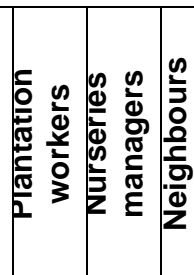 & 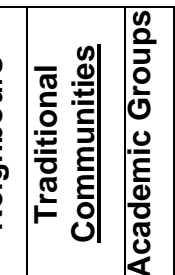 & 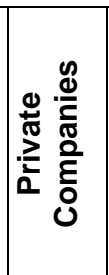 & 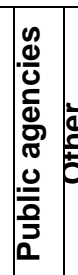 & 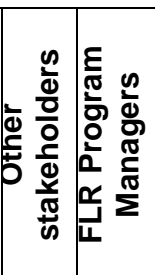 & \\
\hline \begin{tabular}{|l|} 
Criteria \\
\\
Conflict \\
Prevention anc \\
Resolution
\end{tabular} & $\begin{array}{l}\text { To promote conflict prevention and } \\
\text { resolution. }\end{array}$ & & & & & & & & & & & & & & $\begin{array}{l}\text { Chavez-Tafur; Zagt 2014; } \\
\text { Butler et al., } 2015\end{array}$ \\
\hline $\begin{array}{l}\text { Indicator } \\
\text { Participatory } \\
\text { process }\end{array}$ & $\begin{array}{l}\text { To promote the participation of local } \\
\text { communities and other stakeholders } \\
\text { in planning process and decision } \\
\text { making, in order to incorporate their } \\
\text { demands and needs, to avoid } \\
\text { conflicts and to manage trade-offs } \\
\text { between ecological and } \\
\text { socioeconomic outcomes. }\end{array}$ & & & & & & & & & & & & & & $\begin{array}{l}\text { Besseau; Graham; } \\
\text { Christophersen, 2018; } \\
\text { Buckingham; Ray; Stolle; } \\
\text { Zoveda, 2017; } \\
\text { Berrahmouni et al., 2015; } \\
\text { Mansourian, 2017 }\end{array}$ \\
\hline $\begin{array}{l}\text { Indicator } \\
\text { Local } \\
\text { community }\end{array}$ & $\begin{array}{l}\text { To incorporate local community needs } \\
\text { and preferences in the decision } \\
\text { making, implementation and } \\
\text { monitoring processes. }\end{array}$ & & & & & & & & & & & & & & $\begin{array}{l}\text { Besseau; Graham; } \\
\text { Christophersen, 2018; } \\
\text { Hanson; Buckingham; } \\
\text { Dewitt, 2015; } \\
\text { Buckingham; Ray; Stolle; } \\
\text { Zoveda, 2017; } \\
\text { Berrahmouni et al., 2015; }\end{array}$ \\
\hline $\begin{array}{l}\text { Indicator } \\
\text { Engagement }\end{array}$ & $\begin{array}{l}\text { Present evidences of local community } \\
\text { inclusion in planning and execution } \\
\text { processes. }\end{array}$ & & & & & & & & & & & & & & $\begin{array}{l}\text { Hanson; Buckingham; } \\
\text { Dewitt, 2015; } \\
\text { Buckingham; Ray; Stolle; } \\
\text { Zoveda, 2017; }\end{array}$ \\
\hline
\end{tabular}




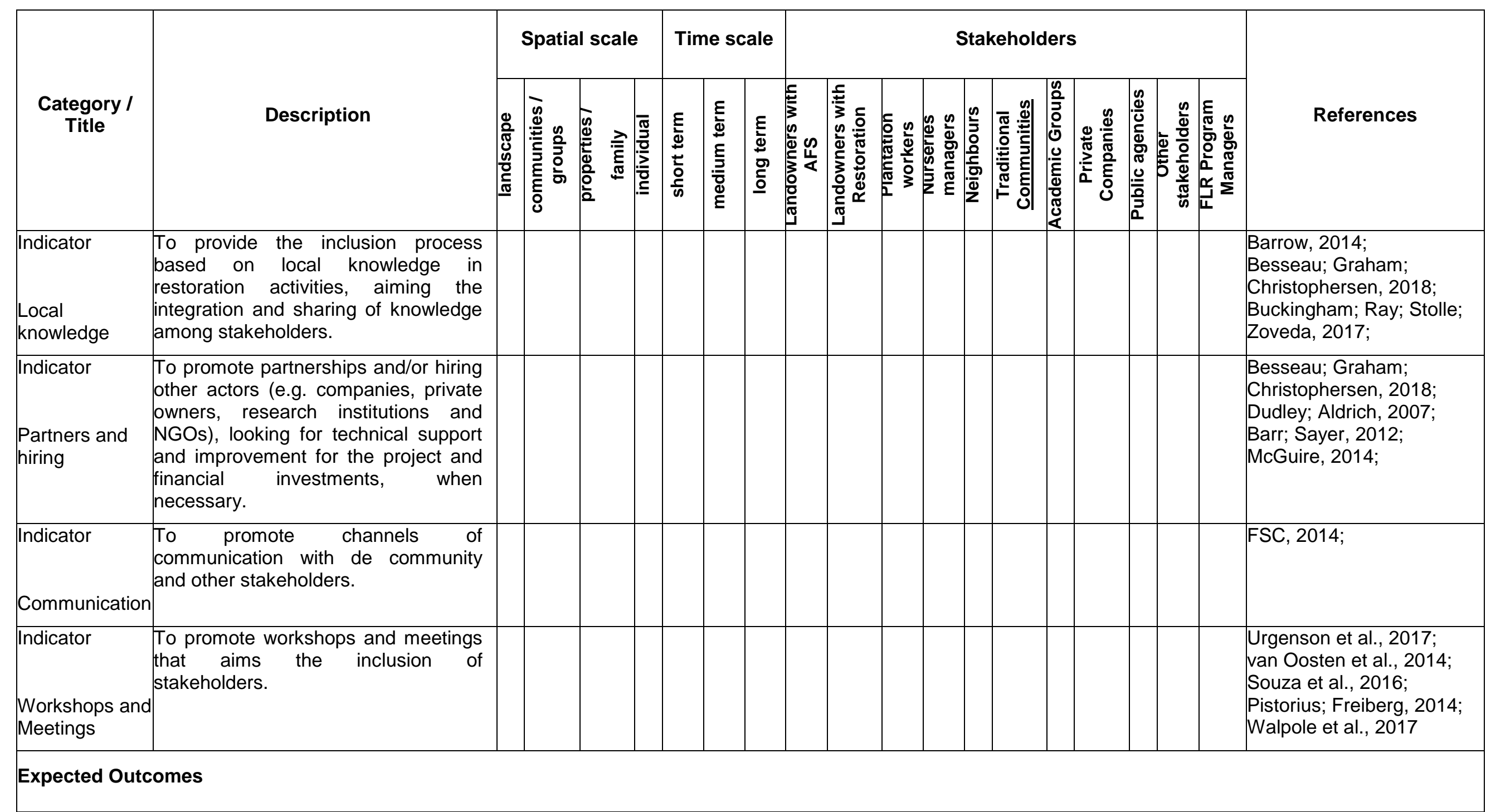




\begin{tabular}{|c|c|c|c|c|c|c|c|c|c|c|c|c|c|c|c|c|}
\hline \multirow[b]{2}{*}{$\begin{array}{l}\text { Category / } \\
\text { Title }\end{array}$} & \multirow[b]{2}{*}{ Description } & \multicolumn{3}{|c|}{ Spatial scale } & \multicolumn{3}{|c|}{ Time scale } & \multicolumn{8}{|c|}{ Stakeholders } & \multirow[b]{2}{*}{ References } \\
\hline & & 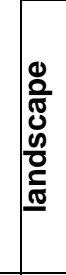 & 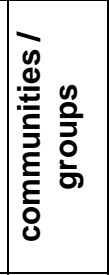 & 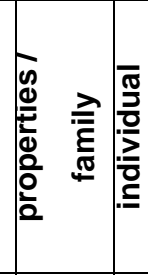 & $\begin{array}{l}\frac{\varepsilon}{\Phi} \\
\Phi \\
\frac{\Xi}{0} \\
\frac{\partial}{\omega}\end{array}$ & 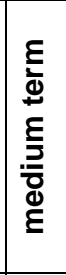 & 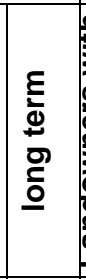 & 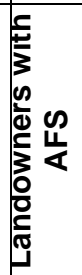 & 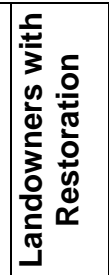 & 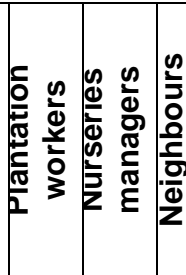 & 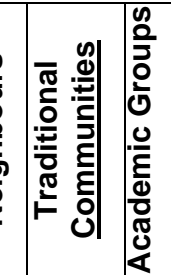 & 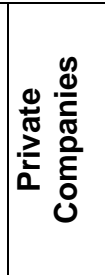 & 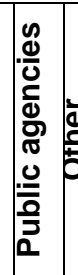 & 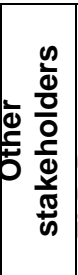 & 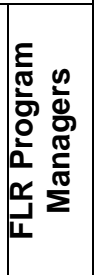 & \\
\hline $\begin{array}{l}\text { Principle } \\
\text { Human } \\
\text { Resilience }\end{array}$ & $\begin{array}{l}\text { The FLR Program must help } \\
\text { improve the human resilience } \\
\text { through the improvement of local } \\
\text { livelihoods, as a result of the } \\
\text { delivery of non-material benefits, } \\
\text { the provision of de natural } \\
\text { resources (such as timber, fuel } \\
\text { wood, non-timber forest products) } \\
\text { for self-consumption, ecosystem } \\
\text { services and market diversification. }\end{array}$ & & & & & & & & & & & & & & & \\
\hline $\begin{array}{l}\text { Criteria } \\
\text { Nonmaterial } \\
\text { benefits }\end{array}$ & $\begin{array}{l}\text { To improve human well-being, by the } \\
\text { enhancement of beauty and quality of } \\
\text { the environment, recreational use and } \\
\text { also the improvement of self-esteem } \\
\text { and confidence because of the } \\
\text { activities and socialization. }\end{array}$ & & & & & & & & & & & & & & & $\begin{array}{l}\text { ITTO, 2006; } \\
\text { Chadourne et al., 2012; } \\
\text { Adams et al., 2016; } \\
\text { FAO; Global Mechanism of } \\
\text { the UNCCD, } 2015\end{array}$ \\
\hline $\begin{array}{l}\text { Indicator } \\
\text { Social } \\
\text { Cohesion }\end{array}$ & $\begin{array}{l}\text { To monitor the level of social cohesion } \\
\text { by the community perception about } \\
\text { the outcomes. }\end{array}$ & & & & & & & & & & & & & & & $\begin{array}{l}\text { Buckingham; Ray; Stolle; } \\
\text { Zoveda, 2017; } \\
\text { FAO; Global Mechanism of } \\
\text { the UNCCD, } 2015\end{array}$ \\
\hline $\begin{array}{l}\text { Indicator } \\
\text { Gender Equity }\end{array}$ & $\begin{array}{l}\text { To promote gender equity through the } \\
\text { inclusion of women in restoration } \\
\text { activities and capacitation programs. }\end{array}$ & & & & & & & & & & & & & & & $\begin{array}{l}\text { Adams et al., 2016; } \\
\text { Báez et al., } 2011\end{array}$ \\
\hline
\end{tabular}




\begin{tabular}{|c|c|c|c|c|c|c|c|c|c|c|c|c|c|c|c|c|}
\hline \multirow[b]{2}{*}{$\begin{array}{l}\text { Category / } \\
\text { Title }\end{array}$} & \multirow[b]{2}{*}{ Description } & \multicolumn{3}{|c|}{ Spatial scale } & \multicolumn{3}{|c|}{ Time scale } & \multicolumn{8}{|c|}{ Stakeholders } & \multirow[b]{2}{*}{ References } \\
\hline & & 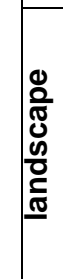 & 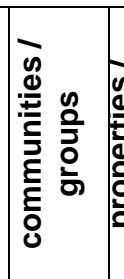 & 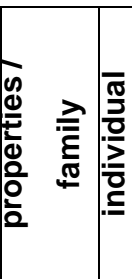 & $\begin{array}{l}\varepsilon \\
\stackrel{\varepsilon}{\Phi} \\
\frac{ \pm}{0} \\
\frac{c}{\omega}\end{array}$ & 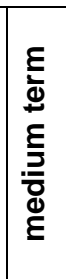 & 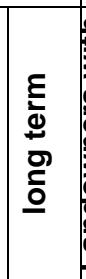 & 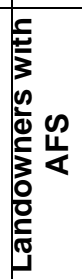 & 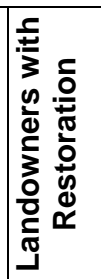 & 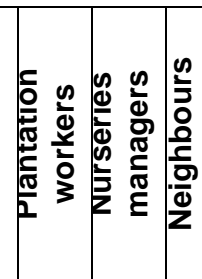 & 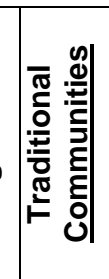 & 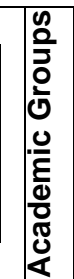 & 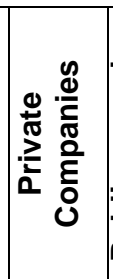 & 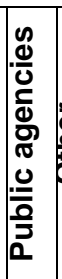 & 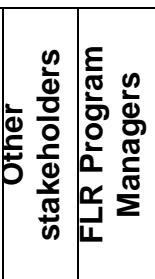 & \\
\hline $\begin{array}{l}\text { Criteria } \\
\text { Monetary } \\
\text { Outcomes }\end{array}$ & $\begin{array}{l}\text { To promote the generation of } \\
\text { monetary income, from } \\
\text { commercialization of forest products } \\
\text { and other natural resources, and the } \\
\text { funding and financial incentives. }\end{array}$ & & & & & & & & & & & & & & & $\begin{array}{l}\text { McLain; Guariguata; Lawry } \\
\text { 2017; } \\
\text { Diederichsen et al., 2017; } \\
\text { IUCN, } 2014\end{array}$ \\
\hline $\begin{array}{l}\text { Indicator } \\
\text { Economic } \\
\text { Diversification }\end{array}$ & $\begin{array}{l}\text { The FLR activities must be planned } \\
\text { and implemented aiming at positive } \\
\text { monetary returns from multiple } \\
\text { sources to local community and } \\
\text { stakeholders. }\end{array}$ & & & & & & & & & & & & & & & $\begin{array}{l}\text { FSC, 2014; } \\
\text { FAO; Global Mechanism of } \\
\text { the UNCCD, 2015; } \\
\text { Diederichsen et al., 2017; } \\
\text { IUCN, 2014 }\end{array}$ \\
\hline $\begin{array}{l}\text { Indicator } \\
\text { Income from } \\
\text { commercializati } \\
\text { on }\end{array}$ & Percentage of variation in income. & & & & & & & & & & & & & & & $\begin{array}{l}\text { Buckingham; Ray; Stolle; } \\
\text { Zoveda, 2017; } \\
\text { Diederichsen et al., } 2017\end{array}$ \\
\hline $\begin{array}{l}\text { Criteria } \\
\text { Non-monetary } \\
\text { outcomes }\end{array}$ & $\begin{array}{l}\text { To provide natural goods (such as } \\
\text { timber, fuel wood, non-timber forest } \\
\text { products) for self-consumption of local } \\
\text { community, ecosystem services and } \\
\text { capacitation. }\end{array}$ & & & & & & & & & & & & & & & $\begin{array}{l}\text { FAO; Global Mechanism of } \\
\text { the UNCCD, 2015; } \\
\text { Diederichsen et al., 2017; } \\
\text { IUFRO, } 2017\end{array}$ \\
\hline $\begin{array}{l}\text { Indicator } \\
\text { Natural Goods } \\
\text { for }\end{array}$ & Volume of natural goods harvested. & & & & & & & & & & & & & & & $\begin{array}{l}\text { Buckingham; Ray; Stolle; } \\
\text { Zoveda, 2017; }\end{array}$ \\
\hline
\end{tabular}




\begin{tabular}{|c|c|c|c|c|c|c|c|c|c|c|c|c|c|c|c|c|c|c|c|}
\hline \multirow[b]{2}{*}{$\begin{array}{c}\text { Category / } \\
\text { Title }\end{array}$} & \multirow[b]{2}{*}{ Description } & \multicolumn{4}{|c|}{ Spatial scale } & \multicolumn{3}{|c|}{ Time scale } & \multicolumn{10}{|c|}{ Stakeholders } & \multirow[b]{2}{*}{ References } \\
\hline & & 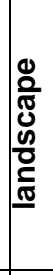 & 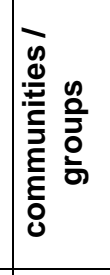 & 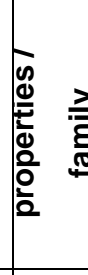 & 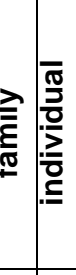 & $\begin{array}{l}\frac{E}{d} \\
\stackrel{⿱}{ \pm} \\
\frac{t}{0} \\
\frac{c}{\omega}\end{array}$ & 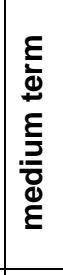 & 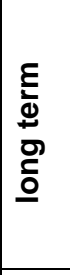 & 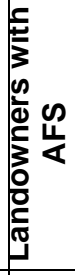 & 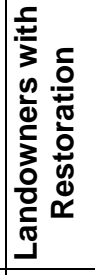 & 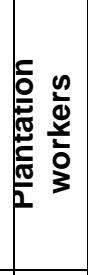 & 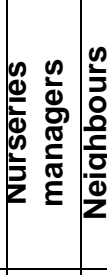 & 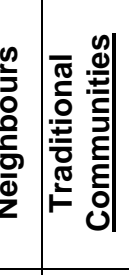 & 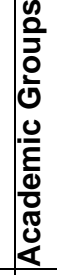 & 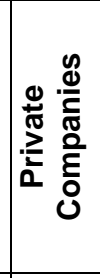 & 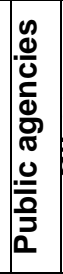 & 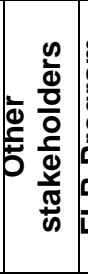 & 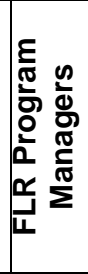 & \\
\hline \multicolumn{20}{|l|}{ consumption } \\
\hline $\begin{array}{l}\text { Indicator } \\
\text { Capacitation } \\
\text { and } \\
\text { Professional } \\
\text { Training }\end{array}$ & $\begin{array}{l}\text { To promote trainings and capacitation } \\
\text { courses, in order to include local } \\
\text { people to implement the range of } \\
\text { activities and interventions involved in } \\
\text { FLR. }\end{array}$ & & & & & & & & & & & & & & & & & & $\begin{array}{l}\text { FSC, 2014; } \\
\text { Buffle; Buss, 2015; } \\
\text { McGuire, 2014 } \\
\text { Gregorio et al., 2017; } \\
\text { IUFRO, } 2017\end{array}$ \\
\hline $\begin{array}{l}\text { Indicator } \\
\text { Job } \\
\text { opportunities }\end{array}$ & $\begin{array}{l}\text { The capacitation and training activities } \\
\text { and the experience in restoration, } \\
\text { should improve the job opportunities } \\
\text { of local people, both in the FLR } \\
\text { program and in other restoration } \\
\text { initiatives. }\end{array}$ & & & & & & & & & & & & & & & & & & $\begin{array}{l}\text { FSC, 2014; } \\
\text { FAO; Global Mechanism of } \\
\text { the UNCCD, 2015; } \\
\text { Diederichsen et al., } 2017\end{array}$ \\
\hline \multicolumn{20}{|c|}{ Management and Monitoring } \\
\hline \begin{tabular}{|l|} 
Principle \\
\\
Adaptive \\
Management
\end{tabular} & $\begin{array}{l}\text { The management and monitoring } \\
\text { process, should be used to identify } \\
\text { the positive and negative results, } \\
\text { improve practices, enhance trust } \\
\text { for financial investments and } \\
\text { identify and overcome challenges. }\end{array}$ & & & & & & & & & & & & & & & & & & $\begin{array}{l}\text { FSC, 2014; } \\
\text { Buckingham; Ray; Stolle; } \\
\text { Zoveda, 2017; }\end{array}$ \\
\hline Criteria & $\begin{array}{l}\text { Identify prior characteristics to } \\
\text { measure project additionality in the } \\
\text { future. }\end{array}$ & & & & & & & & & & & & & & & & & & $\begin{array}{l}\text { Hanson; Buckingham; } \\
\text { Dewitt, 2015; } \\
\text { Buckingham; Ray; Stolle; }\end{array}$ \\
\hline
\end{tabular}

68 


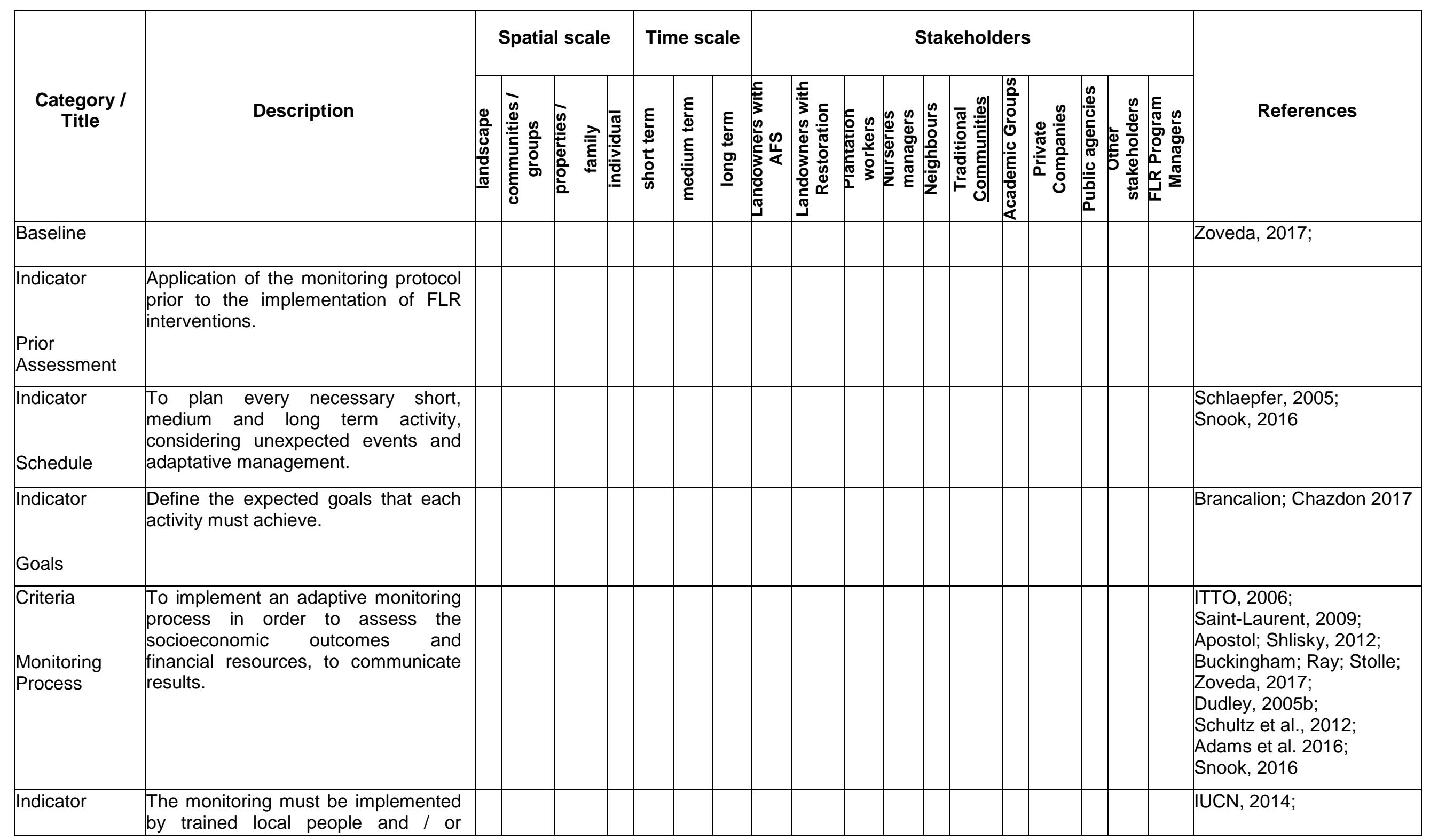




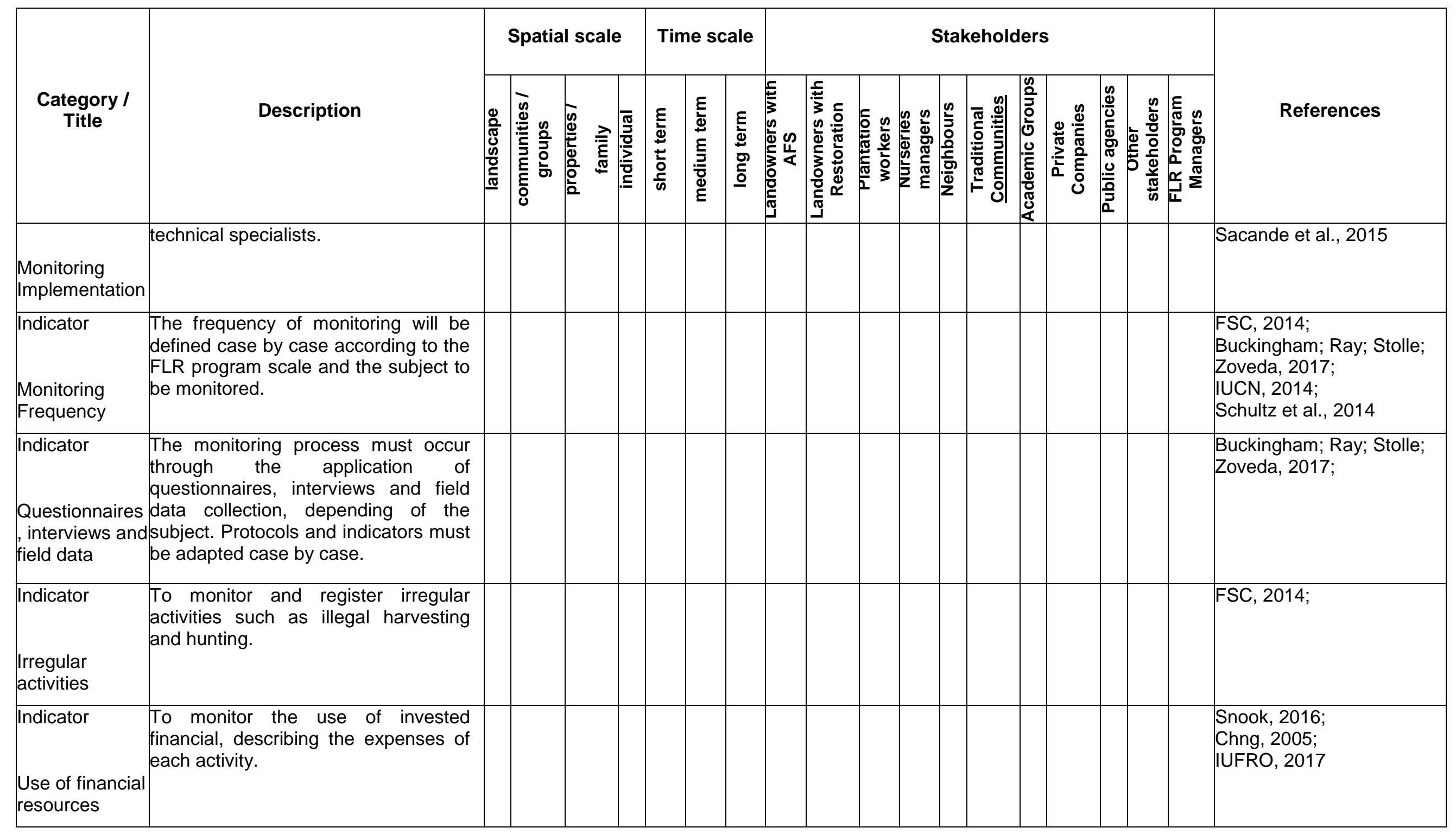




\begin{tabular}{|c|c|c|c|c|c|c|c|c|c|c|c|c|c|c|c|}
\hline \multirow[b]{2}{*}{$\begin{array}{l}\text { Category / } \\
\text { Title }\end{array}$} & \multirow[b]{2}{*}{ Description } & \multicolumn{3}{|c|}{ Spatial scale } & \multicolumn{3}{|c|}{ Time scale } & \multicolumn{7}{|c|}{ Stakeholders } & \multirow[b]{2}{*}{ References } \\
\hline & & 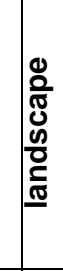 & 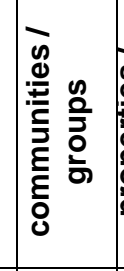 & 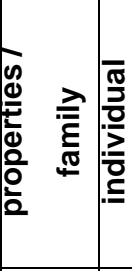 & 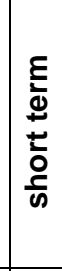 & 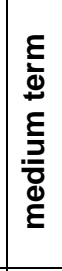 & 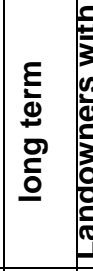 & 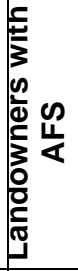 & 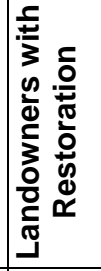 & 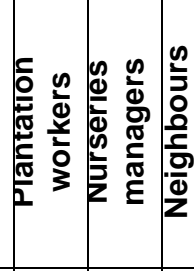 & 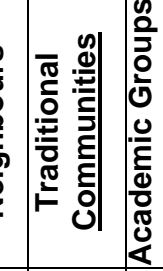 & 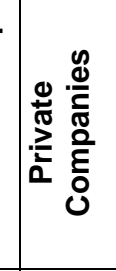 & 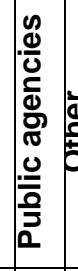 & 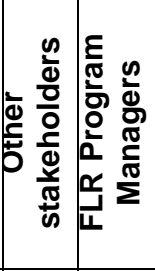 & \\
\hline \begin{tabular}{|l} 
Indicator \\
Distribution of \\
financial \\
resources
\end{tabular} & $\begin{array}{l}\text { To monitor the financial resources } \\
\text { generated by the restoration initiative. }\end{array}$ & & & & & & & & & & & & & & $\begin{array}{l}\text { Chng, 2005; } \\
\text { IUFRO, 2017 }\end{array}$ \\
\hline
\end{tabular}




\section{Planning and Implementation Category}

Although our framework focuses on socioeconomic aspects, we included certain ecological items, when it was not possible to separate them in the FLR design. These ecological aspects appear mainly in the Principles that deal with the project planning phase (i.e. planning and implementation category), where socioeconomic and ecological issues need to be considered together in decision making.

This first category "Planning and Implementation" encompasses three Principles: (i) Landscape, (ii) Legal and Normative Compliance and (iii) Mitigation of Inequalities.

The first one, "Landscape" (Figure 4), states that FLR must work at landscape level, involving multiple land uses and multiple stakeholders, implementing several types of restoration and conservation strategies.

This Principle contains the Criteria "Delimitation of Landscape Area" and its Indicators, related to the activities that FLR managers could do in order to select the landscape area where FLR project will be implemented. Through the Indicators evaluation, it would be possible to identify the landscape area selection was done considering if the main characteristics.

For example, the Indicator Maps and Geoprocessing Programs indicates if the use of these tools to evaluate and select the area were considered (ORSI AND GENELETTI, 2010; ORSI et al., 2011; CHADOURNE et al., 2012; URIBE et al., 2014; HANSON; BUCKINGHAM; DEWITT, 2015, AGER, 2017), while other Indicators evidences if the geographical characteristics (DIEDERICHSEN et al., 2017; SABOGAL et al., 2015; MANSOURIAN 2017), the level of degradation (BUCKINGHAM; RAY; STOLLE; ZOVEDA, 2017; IUCN, 2014; IUFRO, 2017), the types of land uses and the type of properties (LAMB ET AL., 2005; IANNI AND GENELETTI, 2010; VAN OOSTEN, 2013; FAO AND GLOBAL MECHANISM OF THE UNCCD, 2015) also were included in the analysis for landscape area selection.

Besides the delimitation of landscape area, since it will encompass several properties with different types of use, it is also known that there will be different types of stakeholders associated with the project. Also, other stakeholders beyond the landowners and project managers should take part of the project, such as private companies, public agencies, academic groups, material suppliers. It makes necessary to identify and characterise the stakeholders that will be involved in the FLR Program (FSC, 2014). 


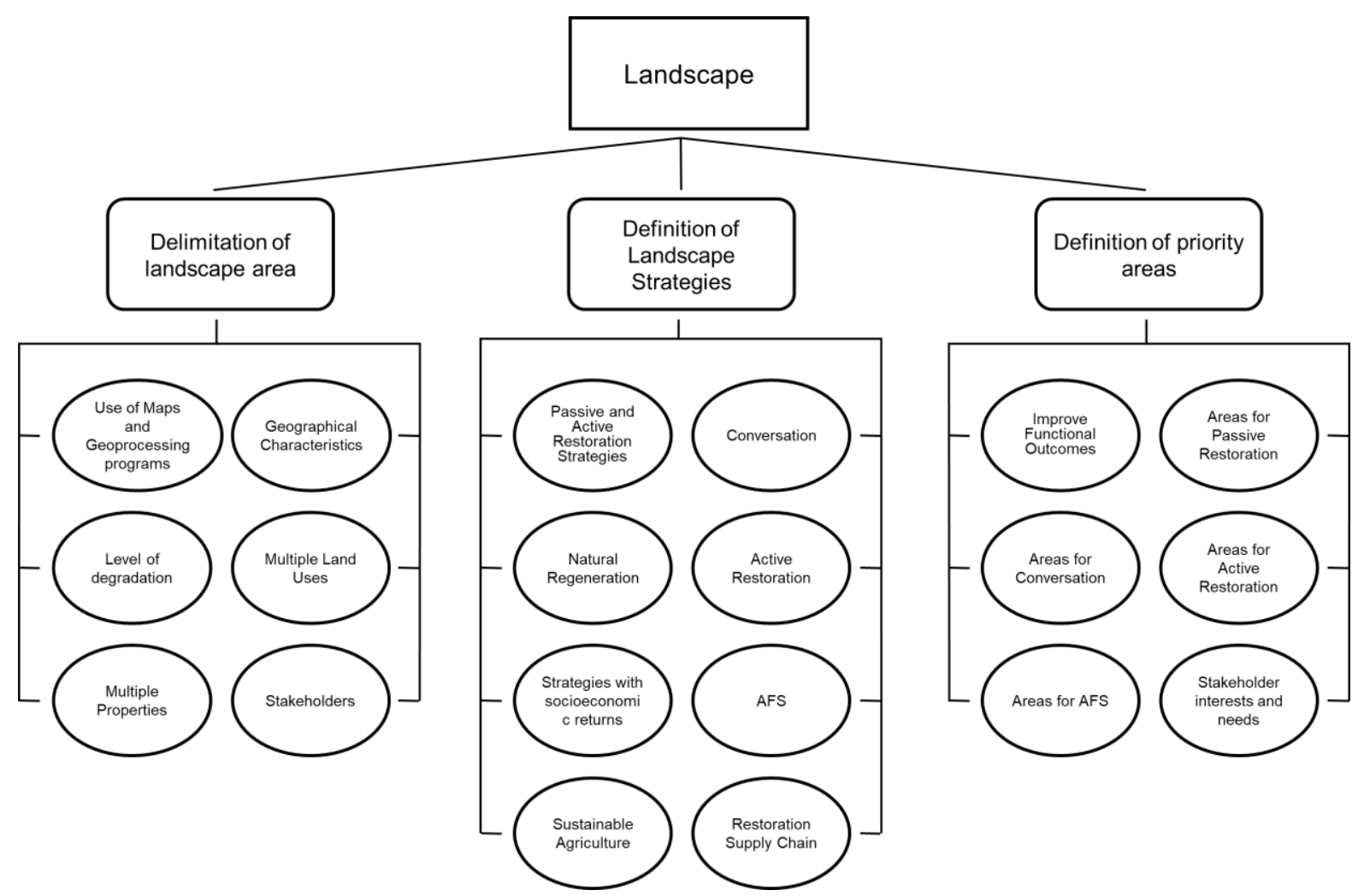

Figure 4 Principle Landscape from Planning and Implementation Category

The Principle "Landscape" also encompasses Criteria and Indicators about the type of restoration strategies that is expected in a FLR project and the definition of where these strategies will be implemented. Since FLR accepts a range of actions and aims at the multiple land uses among the landscape, it makes necessary to plan which strategies will be selected and applied.

The Indicators in these Criteria will allow to identify if the several possible strategies were selected, such as passive and active restoration (ITTO, 2006; MANSOURIAN; VALLAURI, 2014), conservation of forest remnants (BESSEAU; GRAHAM; CHRISTOPHERSEN, 2018; BUDIHARTA et al., 2014; COELLO ET AL., 2015), strategies with socioeconomic returns, such as agroforestry system (AFS) (FAO, 2016; IUFRO, 2017), sustainable agriculture practices (IANNI AND GENELETTI, 2010; ARONSON AND ALEXANDER, 2013; SABOGAL et al., 2015; BRANCALION AND CHAZDON, 2017).

The promotion of the creation and maintenance of local supply chain, such as seedling nurseries, plantation services and other material providers (Adams et al., 2016; Hampson et al., 2017; Gregorio et al., 2017) is also part of the strategies necessary in the FLR projects. 
The definition of where each one of these strategies will be implemented is based on social, economic, political and ecological perspectives, in order to conserve natural remnants, connect fragments, restore degraded areas and to meet stakeholders necessities (FAO; Global Mechanism of the UNCCD, 2015; Chazdon; Uriarte, 2016; Pfund; Stadtmüller, 2005; Mansourian et al., 2017; Dudley et al., 2005).

The second Principle of "Planning and Implementation" category, is "Legal and Normative Compliance" (Figure 5). This Principle establish that the FLR Program must identify and define the laws and norms that it corroborates and influences the Program.

To do so, there have to be evidence of law and norms compliance (FSC, 2014), that will can be achieved after the identification of applicable laws and norms that FLR initiative must help to comply with (FSC, 2014; HANSON; BUCKINGHAM; DEWITT, 2015) and the promotion of knowledge and awareness of compliance with laws and norms for the local community within landscape area (MCLAIN; GUARIGUATA; LAWRY, 2017).

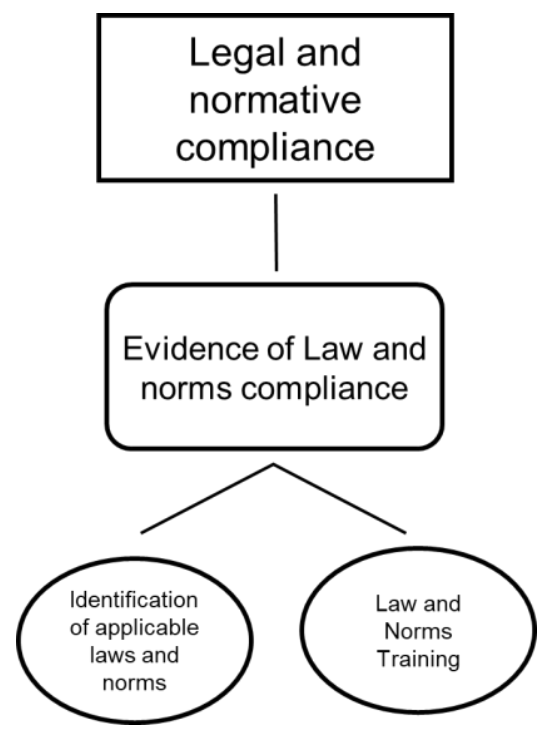

Figure 5 Principle Legal and Normative Compliance from Planning and Implementation Category

Finally, the third Principle of "Planning and Implementation" category is named "Mitigation of Inequalities" (Figure 6) and it is about the promotion of mitigation of inequalities among people within the landscape area. This mitigation can be promoted by ensuring the conflict prevention and resolution (CHAVEZ-TAFUR; ZAGT 2014; BUTLER et al., 2015), in order to promote the participation and inclusion of stakeholders and their needs.

Ways of preventing the conflicts might include the promotion of workshops and meetings as an opportunity for dialogue (URGENSON et al., 2017; VAN OOSTEN et al., 
2014; SOUZA et al., 2016) by incorporating local community needs and preferences in the decision making, implementation and monitoring processes (HANSON; BUCKINGHAM; DEWITT, 2015; BUCKINGHAM; RAY; STOLLE; ZOVEDA, 2017) and also the local knowledge in restoration activities, aiming the integration and sharing of knowledge among stakeholders (BARROW, 2014; BESSEAU; GRAHAM; CHRISTOPHERSEN, 2018; BUCKINGHAM; RAY; STOLLE; ZOVEDA, 2017).

This participatory process aims the incorporation of stakeholders demands and needs, to avoid conflicts and to manage trade-offs between ecological and socioeconomic outcomes (BESSEAU; GRAHAM; CHRISTOPHERSEN, 2018; BUCKINGHAM; RAY; STOLLE; ZOVEDA, 2017; BERRAHMOUNI et al., 2015; MANSOURIAN, 2017) and will be possible through the engagement of people to participate in every step involved in the FLR project (HANSON; BUCKINGHAM; DEWITT, 2015; BUCKINGHAM; RAY; STOLLE; ZOVEDA, 2017).

The availability of communication channels between managers and stakeholders (FSC, 2014) is an evidence that the engagement and the enhancement of participation is being promoted.

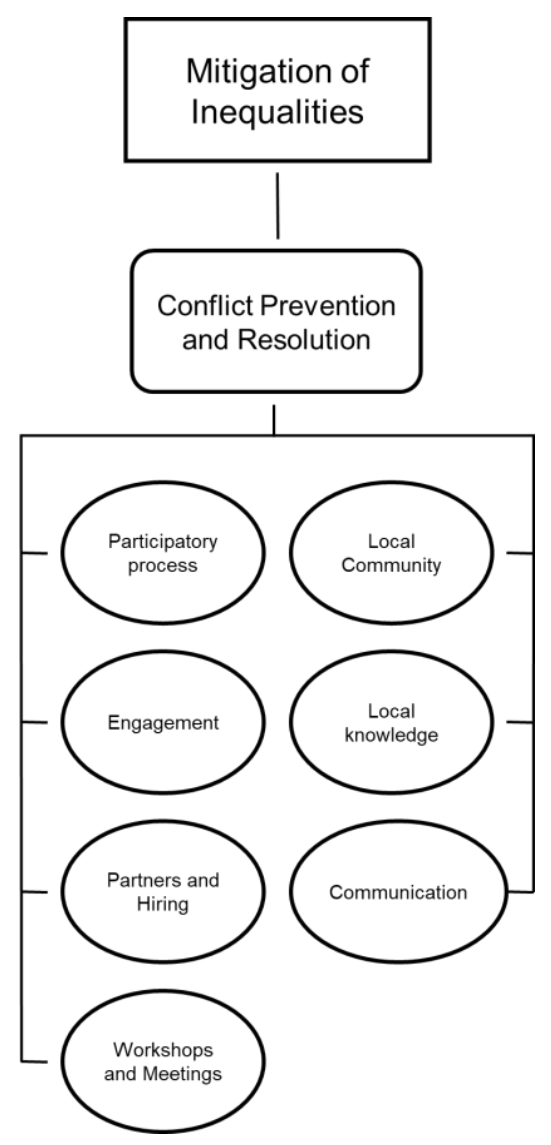

Figure 6 Principle Mitigation of Inequalities from Planning and Implementation Category 


\section{Expected Outcomes Category}

The second category of the Socioeconomic Standard, "Expected Outcomes", have one Principle, named "Human Resilience" (Figure 7), with three criteria: nonmaterial benefits, monetary outcomes and non-monetary outcomes. It is expected that the FLR project provide a range of positive outcomes for people within the landscape, aiming at the human resilience through the improvement of local livelihoods, as a result of the delivery of non-material benefits, the provision of de natural resources (such as timber, fuel wood, non-timber forest products) for self-consumption, ecosystem services and market diversification (BESSEAU; GRAHAM; CHRISTOPHERSEN, 2018).

The nonmaterial benefits are related to the improvement of human well-being, by the enhancement of beauty and quality of the environment, recreational use and also the improvement of self-esteem and confidence because of the activities and socialization (ITTO, 2006; CHADOURNE et al., 2012; ADAMS et al., 2016; FAO; GLOBAL MECHANISM OF THE UNCCD, 2015). The assessment of this benefits is related to the distribution of results among the landscape and the community perception about outcomes (BUCKINGHAM; RAY; STOLLE; ZOVEDA, 2017; FAO; GLOBAL MECHANISM OF THE UNCCD, 2015).

The promotion of gender equity, by including women in restoration activities and capacitation programs, might also indicate an improvement of human well-being and resilience, since these activities may provide empowerment and income alternatives for women (ADAMS et al., 2016; BÁEZ et al., 2011).

The monetary outcomes achievement might be indicated by the identification of economic diversification from multiple sources to local community and stakeholders (FSC, 2014; FAO; GLOBAL MECHANISM OF THE UNCCD, 2015; DIEDERICHSEN et al., 2017; IUCN, 2014). It can be verified through the commercialization of natural products resulting from the restoration activities and the commercialization of other materials needed for project implementation, that might generate an increase in the participants income (BUCKINGHAM; RAY; STOLLE; ZOVEDA, 2017; DIEDERICHSEN et al., 2017).

Non-monetary results, on the other hand, are those derived from the self-consumption of natural goods and from the capacitation, professional training and job opportunities generation (FAO; GLOBAL MECHANISM OF THE UNCCD, 2015; DIEDERICHSEN ET AL., 2017; IUFRO, 2017). 


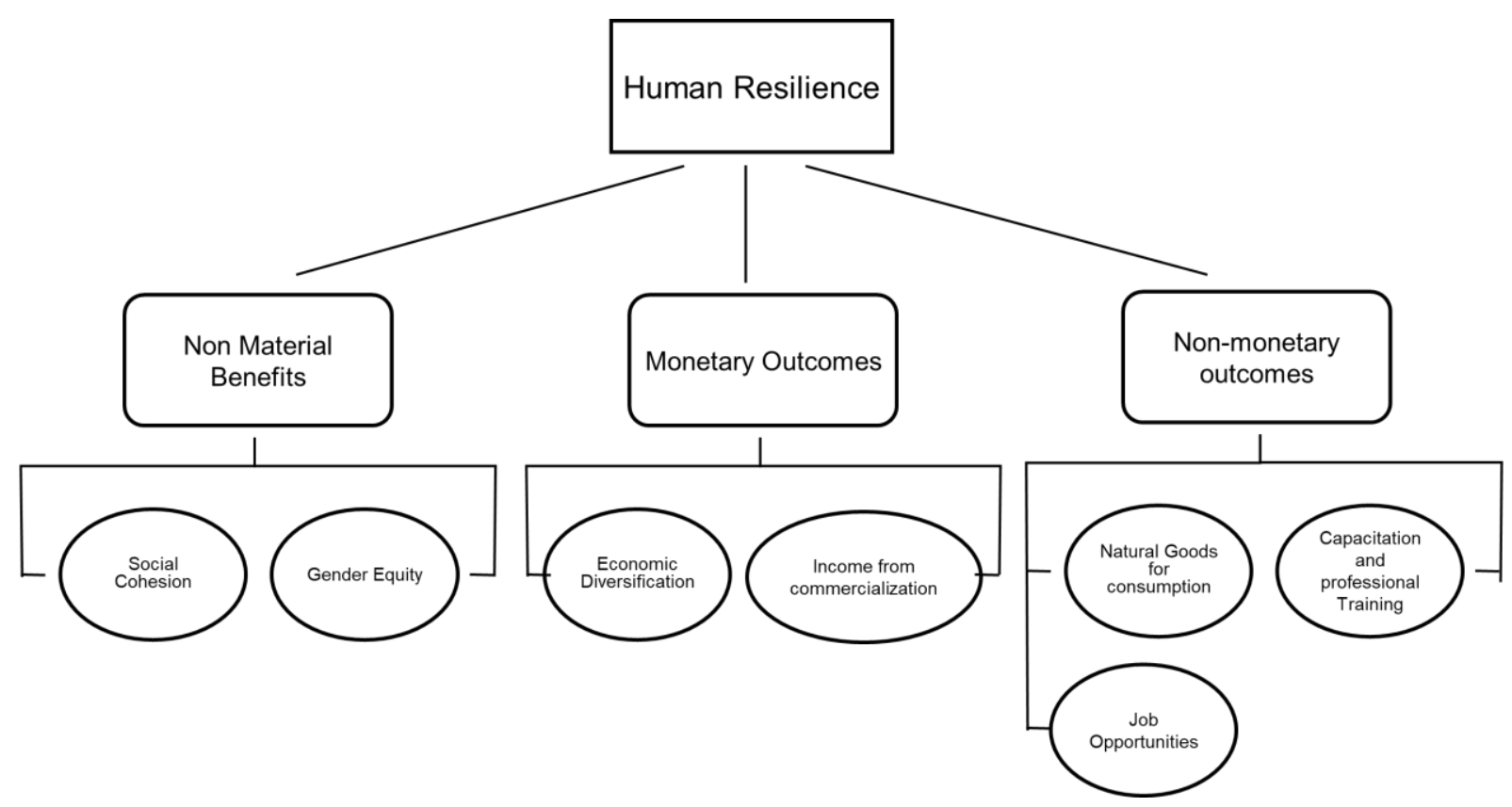

Figure 7 Principle Human Resilience from Expected Outcomes Category

\section{Management and Monitoring Category}

Finally, the third category, "Management and Monitoring", encompasses the Principle named "Adaptive Management", with two criteria: baseline and monitoring process (Figure 8). This principle establishes that the management and monitoring process, should be used to identify the positive and negative results, improve practices, enhance trust for financial investments and identify and overcome challenges.

In the begging of FLR project, managers would collect data to stablish the baseline, that will be necessary to identify the initial situation and that will allow comparison with the results obtained throughout the project (HANSON; BUCKINGHAM; DEWITT, 2015; BUCKINGHAM; RAY; STOLLE; ZOVEDA, 2017). Also, in the planning process the schedule of the short, medium and long term activity, will be defined considering unexpected events and adaptative management (SCHLAEPFER, 2005; SNOOK, 2016), considering the expected goals that each activity must achieve (BRANCALION; CHAZDON 2017).

The monitoring process is essential to verify the socioeconomic outcomes and to communicate results. This will be possible with the inclusion of trained local people or technical specialists in the development of monitoring activities (IUCN, 2014; SACANDE et al., 2015). And the quality of data can be indicated by the types of technics used, combining application of questionnaires, interviews and field data collection, depending of the subject (BUCKINGHAM; RAY; STOLLE; ZOVEDA, 2017) that must be applied in accordance with 
the needed frequency for each indicator (FSC, 2014; BUCKINGHAM; RAY; STOLLE; ZOVEDA, 2017; IUCN, 2014; SCHULTZ et al., 2014).

Every monitoring activity will be defined case by case according to the FLR project scale and the subject to be monitored (FSC, 2014; BUCKINGHAM; RAY; STOLLE; ZOVEDA, 2017; IUCN, 2014; SCHULTZ et al., 2014).

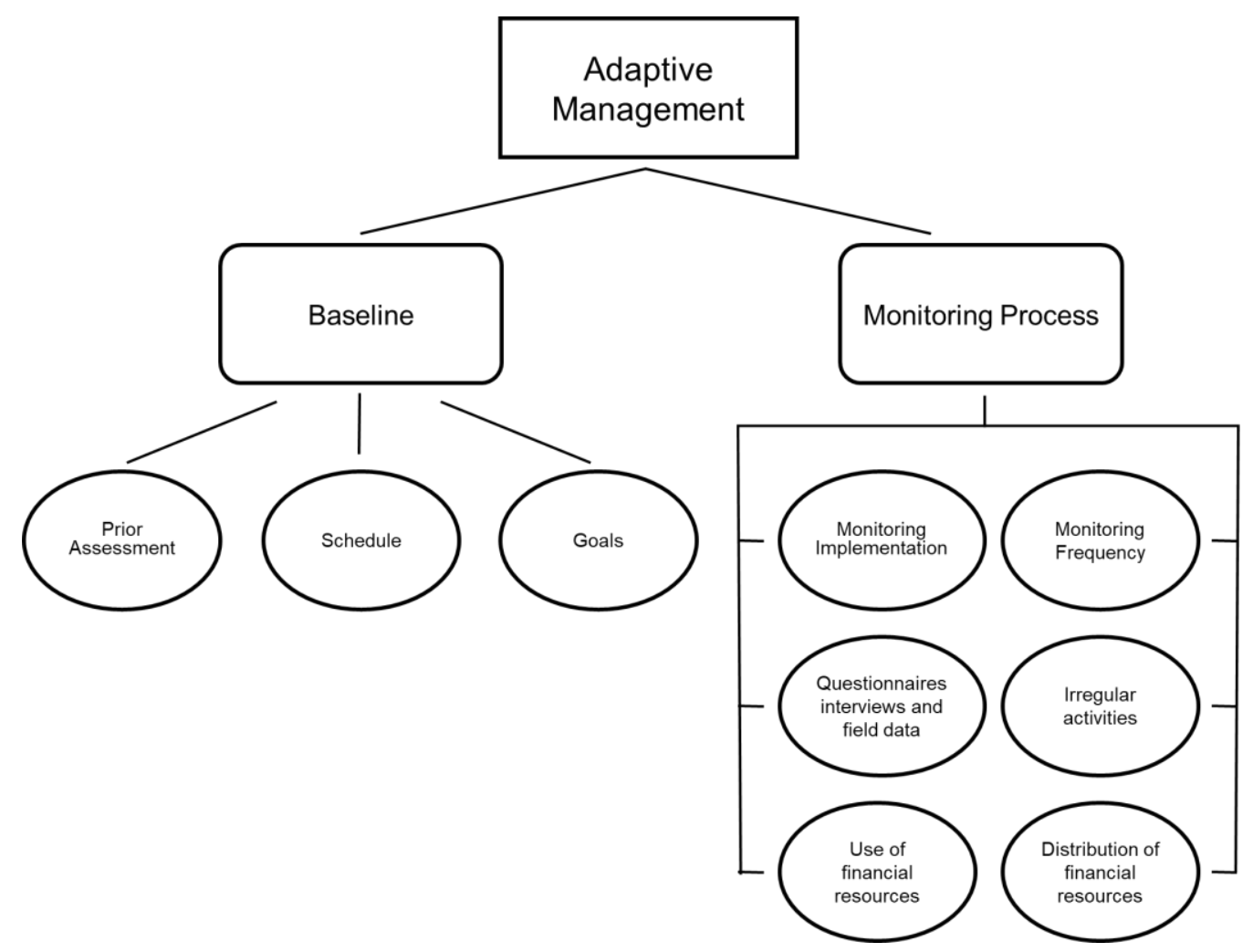

Figure 8 Principle Adaptive Management from Management and Monitoring Category

\section{Categories for guidance}

Because of the dynamic and complexity of FLR projects, beyond the Principle., Criteria and Indicators, the Standard Framework also includes three categories for guidance that might help on its application and, consequently in the management of FLR: (i) spatial scale, (ii) time scale and (iii) stakeholders.

Even though FLR is a landscape level activity, both the interventions implemented, and their outcomes might address different spatial scales. For example, capacity building and training may generate individual level benefits, while including the local community in decision making encompasses the whole landscape. Because of that, we also included the category "spatial scale", that FLR managers might use to control different scales (e.g. 
landscape, communities or groups, properties or family and individual) affecting each socioeconomic aspect.

FLR is a long-term process and has several implementation steps with several actions happening simultaneously, and with different implementation and monitoring deadlines. We therefore considered that indicators will also be adaptable to these different time scales, so we included category "time scale" in the framework aiming the control of the time scale for each item. Regarding monitoring, more specifically, each indicator requires a monitoring pace, so it is important to have this type of control and assessment.

Since FLR involves multiple land uses and properties, the framework also incorporated the category "stakeholders", to help in the management and identification of how several actors are involved in the project, such as: landowners with SAFs, landowners with restoration, plantation workers, nurseries managers, neighbours, traditional communities, academic groups, private companies, public agencies, FLR project managers and other stakeholders, depending of each context.

The standardisation framework is a consolidation of literature information about FLR and so, it may present aspects that are not applicable for every FLR project. Managers may adapt the standard framework, considering what topics are applicable, in what time and space scale the actions are being implemented and generating impact and what group of actors are involved.

\subsubsection{Interview Protocols Models}

Based on the Indicators present in the Socioeconomic Standard Framework, we developed the questions that might help to identify if each action was implemented and if it is generating the expected outcome.

As we already pointed, since FLR embraces different land uses and multiple properties, it is expected that different types of stakeholder will present in the landscape. We than developed three models of Interview Protocol for (i) FLR program managers (Annex II), (ii) landscape inhabitants who participated in the restoration activities (Annex III), and (iii) for people inserted in the landscape area under restoration but who did not participate in the restoration activities (Annex IV). 
Beyond the three models serve as a first draft to be tested, improved and used in the monitoring process of FLR projects ${ }^{5}$, the application of these models in the field might also help to understand the current quality of the Socioeconomic Standard Framework. It may be useful to understand gaps and needed improvements and modifications in the framework.

It is important to highlight that, as we pointed before, beyond interviews, the monitoring of FLR Programs might be done by the combination of several strategies, such as document analysis, field observation and application of questionnaires (BUCKINGHAM; RAY; STOLLE; ZOVEDA, 2017).

\subsection{Discussion and Conclusion}

Despite socioeconomic aspects is less present than ecological aspects in the literature, when compared to the scientific literature of ecological restoration, we could observe those aspects more often included in FLR initiatives. This might occur because of the evolution in the approach that FLR aims to achieve, integrating ecological with socioeconomic objectives (REINECKE; BLUM, 2018). Because of that is it possible to assume that the Socioeconomic Standard Framework significantly addresses the socioeconomic aspects expected for FLR.

However, we identified some weaknesses in FLR literature: there are no studies about how to monitor or evaluate socioeconomically this type of intervention considering its landscape scale. This is an inherent difficult in the research held on integrated social and natural systems. At landscape level, the use of replicate landscapes to comparison is almost non-existent (SAYER et al., 2017).

We have attempted to begin to fulfill this gap by suggesting the inclusion in the monitoring process of those who have not participated in the FLR project but are part of the landscape, as it is expected that the project impact should be perceived at landscape level and not only those who have effectively participated.

Although there is already an initiative for landscape assessment that considers some socio-economic aspects, such as WWF's LOAM - Landscape Outcome Assessment Methodology (ALDRICH; SAYER, 2007), Sayer et al. (2018) reinforces that because of the "dynamism of landscapes and the stakeholders operating within them, there is a fundamental requirement for metrics along this entire continuum of effects".

\footnotetext{
5 The first application of the questionnaires will be carried out in a parallel project, which will collect information from a landscape restoration project implemented in the Pontal do Paranapanema region (Southeastern Brazil).
} 
Moreover, the lack of evidence that an impact has occurred does not mean that it is not present. There is a need to think about ways to more fully identify short medium and long projects impacts through monitoring strategies, since this difficult in assessing landscape interventions success delays the chance to learn from prior projects (SAYER et al., 2017).

It is important to note that this is the first version of the Socioeconomic Standard Framework and of the Interview Protocols Models, that must be reviewed and improved by testing it in existing FLR projects and by evaluating and discussing it with experts from the scientific/practice area. 


\subsection{References}

ADAMS C, RODRIGUES ST, CALMON M, KUMAR C. Impacts of large-scale forest restoration on socioeconomic status and local livelihoods: what we know and do not know. Biotropica 48:731-744. 2016. 2016.

AGER AA, VOGLER KC, DAY MA, BAILEY JD. Economic Opportunities and Trade-Offs in Collaborative Forest Landscape Restoration. Ecol Econ 136:226-239, 2016.

ALDRICH, M.; SAYER, J. Landscape Outcomes Assessment Methodology “LOAM”. 2007.

APOSTOL D, SHLISKY A. Restoring Temperate Forests: A North American Perspective, 2nd edn. 2012.

ARONSON, J. et al. Are socioeconomic benefits of restoration adequately quantified? a metaanalysis of recent papers (2000-2008) in restoration ecology and 12 other scientific journals. Restoration Ecology, v. 18, n. 2, p. 143-154, 2010.

ARONSON J, ALEXANDER S. Steering towards sustainability requires more ecological restoration. Nat a Conserv 11:127-137, 2013.

ASHTON MS, GOODALE UM, BAWA K.S. Restoring working forests in human dominated landscapes of tropical South Asia: An introduction. For Ecol Manage 329:335-339, 2014.

AULD, G.; GULBRANDSEN, L. H.; MCDERMOTT, C. L. Certification Schemes and the Impacts on Forests and Forestry. Annual Review of Environment and Resources, v. 33, n. 1, p. 187-211, 2008. Disponível em: <http://www.annualreviews.org/doi/10.1146/annurev.environ.33.013007.103754>.

BÁEZ S, AMBROSE E.K., HOFSTEDE E.E.R, SUR I. Ecological and social bases for the restoration of a High Andean cloud forest: preliminary results and lessons from a case study in northern Ecuador. Trop Mont Cloud For Sci Conserv Manag 628-642, 2011.

BARROW E. 300,000 hectares restored in Shinyanga, Tanzania — but what did it really take to achieve this restoration? SaPIEnS 7:1-8, 2014.

BERRAHMOUNI N, PARFONDRY M, REGATO P, SARRE A. Restoration of degraded forests and landscapes in drylands: Guidelines and way forward. Unasylva 66:37-41, 2015.

BERNARD, H. R. et al. The problem of informant accuracy: The validity of retrospective data. In: Annual review of anthropology. [s.l: s.n.]p. 495-517.

BESSEAU, P.; GRAHAM, S.; CHRISTOPHERSEN, T. Restoring Forest and Landscapes: The key to a sustainable future. Global Partnership of Forest Landscape Restoration, v. Vienna, Au, 2018.

BRANCALION, P.H.S; CHAZDON, R.L. Beyond hectares: four principles to guide reforestation in the context of tropical forest and landscape restoration. Restoration ecology, 
v. 25, n. 4, p. 491-496, 2017.

BUCKINGHAM, K. et al. Measuring Progress for Forest and Landscape Restoration. WORLD RESOURCES INST ITUTE WITH FOOD AGRICULTURE ORGANIZATION OF THE UNITED NATIONS, 2017.

BUDIHARTA S, MEIJAARD E, ERSKINE PD, et al. Restoring degraded tropical forests for carbon and biodiversity. Environ Res Lett 9:114020, 2014

BUFFLE, P., \& BUSS, C. 3.7 Forest and farm producers and forest landscape restoration. Effective Forest and Farm Producer Organizations, (57), 197-204, 2015.

BUTLER WH, MONROE A, MCCAFFREY S. Collaborative Implementation for Ecological Restoration on US Public Lands: Implications for Legal Context, Accountability, and Adaptive Management. Environ Manage 55:564-577, 2015.

CHADOURNE MH, Cho SH, Roberts RK. Identifying Priority Areas for Forest Landscape Restoration to Protect Ridgelines and Hillsides: A Cost-Benefit Analysis. Can J Agric Econ 60:275-294. 2015.

CHAVEZ-TAFUR J, ZAGT R. Towards productive landscapes. ETFRN News 224, 2014.

CHAZDON, R. L. et al. When is a forest a forest? Forest concepts and definitions in the era of forest and landscape restoration. Ambio, v. 45, n. 5, p. 538-550, 2016.

CHAZDON, R. L.; URIARTE, M. Natural regeneration in the context of large-scale forest and landscape restoration in the tropics. Biotropica, v. 48, n. 6, p. 709-715, 2016.

CHNG S.K. Marketing and Communications Opportunities: How to Promote and Market Forest Landscape Restoration. In: Mansourian S, Vallauri D, Dudley N (eds) Forest Restoration in Landscapes, 2015.

COELLO J, CORTINA J, VALDECANTOS A, VARELA E. Forest landscape restoration experiences in southern Europe: Sustainable techniques for enhancing early tree performance. Unasylva 66:82-90, 2015.

DE HAAN, L. J. Globalization, localization and sustainable livelihood. Sociologia Ruralis, v. 40, p. 339-365, 2000.

DELGADO, C.; WOLOSIN, M.; PURVIS, N. Restoring and protecting agricultural and forest landscapes and increasing agricultural productivity. Working paper for Seizing the Global Opportunity: Partnerships for Better Growth and a Better Climate, p. 1-44, 2015. Disponível em: <http://2015.newclimateeconomy.report/wpcontent/uploads/2015/12/NCE-restoring-protecting-ag-forest-landscapes-increase-ag.pdf $>$.

DIAZ-CHAVEZ, R. Socio-Economic Impacts of Bioenergy Production. p. 17-27, 2014. Disponível em: <http://link.springer.com/10.1007/978-3-319-03829-2>.

DIEDERICHSEN A, GATTI G, NUNES S, PINTO A. Diagnostic of Key Success Factors for Forest Landscape Restoration: Municipality of Paragominas and The State of Pará. Curitiba, 
2017.

DUDLEY N. Case study: monitoring forest landscape restoration in Vietnam. In: Mansourian, S., D. Vallauri and ND (ed) Forest Restoration in Landscapes: Beyond Planting Trees. pp 157-158, 2005.

DUDLEY, N.; MANSOURIAN, S.; VALLAURI, D. Forest Landscape Restoration in context. In: MANSOURIAN, S.; VALLAURI, D.; DUDLEY, N. (Ed.). Forest Restoration in Landscapes: Beyond Planting Trees. 2005.

FAO. Forest landscape restoration for Asia-Pacific forests. 198. 2016.

FAO; GLOBAL MECHANISM OF THE UNCCD. Sustainable financing for forest and landscape restoration: opportunities, challenges and the way forward. [s.l: s.n.].

FOWLER, F. J. Improving Survey Questions: Design and Evaluation. [s.l: s.n.]

GPFLR. Forest Landscape Restoration: See the Bigger Picture. International Union for Conservation Nature, 2008.

GREGORIO, N. et al. Regulating the quality of seedlings for forest restoration: Lessons from the National Greening Program in the Philippines. Small-scale forestry, v. 16, n. 1, p. 83102, 2017.

GUTIERREZ, V.; KEIJZER, M. N. Funding forest landscape restoration using a businesscentred approach: an NGO's perspective. Unasylva, v. 66, n. 245, p. 99, 2015.

HAMPSON, K. et al. "There is No Program Without Farmers": Interactive Radio for Forest Landscape Restoration in Mount Elgon Region, Uganda. Society \& Natural Resources, v. 30, n. 5, p. 642-657, 2017.

HANSON, C. et al. The restoration diagnostic. A method for developing forest landscape restoration strategies by rapidly assessing the status of key success factors. 2015 .

IANNI, Elena; GENELETTI, Davide. Applying the ecosystem approach to select priority areas for forest landscape restoration in the Yungas, Northwestern Argentina. Environmental management, v. 46, n. 5, p. 748-760, 2010.

ITTO. Guidebook for the formulation of afforestation and reforestation projects under the clean development mechanism. 2006.

IUCN. Forest landscape restoration potential and impacts. Arbovitae 45:16. 2014.

IUFRO. Implementing Forest Landscape Restoration: a practitioner's guide. Viena, Austria, 2017.

IUFRO, World Resources Institute Forest Landscape Restoration as a Strategy for Mitigating and Adapting to Climate Change Context.

LAESTADIUS, L. et al. Before Bonn and beyond: the history and future of forest landscape 
restoration. Unasylva, v. 245, n. 66, p. 11-17, 2015.

LAMB, David; ERSKINE, Peter D.; PARROTTA, John A. Restoration of degraded tropical forest landscapes. Science, v. 310, n. 5754, p. 1628-1632, 2005.

MAGINNIS, Stewart; JACKSON, William. The role of planted forests in forest landscape restoration. In: Proceedings of the UNFF Intersessional Experts Meeting on the Role of Planted Forests in Sustainable Forest Management. p. 87-99, 2003.

MANSOURIAN, S. et al. Understanding the relationship between governance and forest landscape restoration. Conservation and Society, v. 14, n. 3, p. 267, 2016.

MANSOURIAN, S.; DUDLEY, N. Challenges for forest landscape restoration based on WWF's experience to date. In: Forest Restoration in Landscapes. Springer, New York, NY, 2005. p. 94-100.

MANSOURIAN, Stephanie et al. Forest Landscape Restoration: increasing the positive impacts of forest restoration or simply the area under tree cover?. Restoration Ecology, v. 25, n. 2, p. 178-183, 2017.

MANSOURIAN, S.; VALLAURI, D. Restoring forest landscapes: important lessons learnt. Environmental Management, v. 53, n. 2, p. 241-251, 2014.

MCGUIRE, D. 2.1 Fao's Forest and landscape restoration Mechanism. Towards productive landscapes, p. 19, 2014.

MCLAIN, R.; GUARIGUATA, M. R.; LAWRY, S. Implementing Forest Landscape Restoration Initiatives Tenure, Governance, and Equity Considerations. Accelerating Restoration of Degraded Forest Landscapes: The Role of Tenure Security and Local Forest Governance in Catalyzing Global Restoration Initiatives, 2017.

NIJNIK, M.; HALDER, P. Afforestation and reforestation projects in South and South-East Asia under the Clean Development Mechanism: Trends and development opportunities. Land Use Policy, v. 31, p. 504-515, 2013.

NUSSBAUM, R.; SIMULA, M. The forest certification handbook second edition. Earth Scan publication Ltd, London, 2005.

ORSI, F.; CHURCH, R.L. GENELETTI, Davide. Restoring forest landscapes for biodiversity conservation and rural livelihoods: A spatial optimisation model. Environmental Modelling \& Software, v. 26, n. 12, p. 1622-1638, 2011.

ORSI, F.; GENELETTI, D. Identifying priority areas for Forest Landscape Restoration in Chiapas (Mexico): An operational approach combining ecological and socioeconomic criteria. Landscape and Urban Planning, v. 94, n. 1, p. 20-30, 2010.

PFUND, J. L.; STADTMÜLLER, T. Forest landscape restoration (FLR). Inforesources focus, v. 2, n. 05, 2005.

PISTORIUS T, FREIBERG $H$. From target to implementation: Perspectives for the 
international governance of forest landscape restoration. Forests 5:482-497. doi: 10.3390/f5030482. 2014.

REINECKE, S., BLUM, M. Discourses across scales on forest landscape restoration. Sustainability, v. 10, n. 3, p. 613, 2018

ROCCO, B. C. M. Avaliação ecológica e da percepção de proprietários rurais do processo de restauração de matas ciliares em Jaú e Saltinho - SP. 2013.

SABOGAL C, BESACIER C, MCGUIRE D. Forest and landscape restoration: Concepts, approaches and challenges for implementation. In: Lapstun S (ed) Unasylva. pp 3-10, 2015.

SACANDE, M.; BERRAHMOUNI, N.; HARGREAVES, S. Community participation at the heart of Africa's Great Green Wall restoration model 1. Unasylva, v. 66, n. 245, p. 44, 2015.

SAINT-LAURENT, C. Optimizing synergies on forest landscape restoration between the Rio conventions and the UN forum on forests to deliver good value for implementers. Rev. Eur. Comp. \& Int'l Envtl. L., v. 14, p. 39, 2005.

SAINT-LAURENT C. The Global Partnership on Forest Landscape Restoration. 2009.

SAYER, J.; CAMPBELL, B. The science of sustainable development: local livelihoods and the global environment. [s.1.] Cambridge University Press, 2004.

SAYER, J. A. et al. Measuring the effectiveness of landscape approaches to conservation and development. Sustainability Science, v. 12, n. 3, p. 465-476, 2017.

SCHLAEPFER, Rodolphe. Ecosystem approach and ecosystem management as the fundaments of forest landscape restoration strategies. Forest landscape restoration in Central and Northern Europe. EFI Proceedings, v. 53, p. 69-81, 2005.

SCHULTZ, COURTNEY A.; COELHO, DANA L.; BEAM, RYAN D. Design and governance of multiparty monitoring under the USDA Forest Service's Collaborative Forest Landscape Restoration Program. Journal of Forestry, v. 112, n. 2, p. 198-206, 2014.

SCHULTZ, Courtney A.; JEDD, Theresa; BEAM, Ryan D. The Collaborative Forest Landscape Restoration Program: a history and overview of the first projects. Journal of Forestry, v. 110, n. 7, p. 381-391, 2012.

SER, S. for E. R. Princípios da SER International sobre a restauração ecológica. SER, Society for Ecological Restoration International, p. 15, 2004. Available on: 〈http://www.ser.org/>.

SNOOK, L. Safeguarding Investments in Forest Ecosystem Restoration Safeguarding investments in forest ecosystem restoration Policy Brief. n. February, 2016.

SOUZA, S EX F et al. Ecological outcomes and livelihood benefits of community-managed agroforests and second growth forests in Southeast Brazil. Biotropica, v. 48, n. 6, p. 868-881, 2016.

UPTON, C.; BASS, S. The forest certification handbook. [s.1.] Earthscan Publications Ltd, 
1995.

URGENSON, L.S. et al. Visions of restoration in fire-adapted forest landscapes: lessons from the Collaborative Forest Landscape Restoration Program. Environmental management, v. 59, n. 2, p. 338-353, 2017.

URIBE, D. et al. Integrating stakeholder preferences and GIS-based multicriteria analysis to identify forest landscape restoration priorities. Sustainability, v. 6, n. 2, p. 935-951, 2014.

VAN OOSTEN, C. Restoring landscapes - governing place: a learning approach to forest landscape restoration. Journal of sustainable forestry, v. 32, n. 7, p. 659-676, 2013.

VAN OOSTEN, Cora et al. Governing forest landscape restoration: Cases from Indonesia. Forests, v. 5, n. 6, p. 1143-1162, 2014.

WALPOLE EH, TOMAN E, WILSON RS, STIDHAM M Shared visions, future challenges: a case study of three Collaborative Forest Landscape Restoration Program locations. Ecology and Society, v. 22, n. 2, 2017.

WORTLEY, L.; HERO, J. M.; HOWES, M. Evaluating ecological restoration success: A review of the literature. Restoration Ecology, v. 21, n. 5, p. 537-543, 2013.

YOUNG, T. P.; PETERSEN, D. A.; CLARY, J. J. The ecology of restoration: Historical links, emerging issues and unexplored realms. Ecology Letters, v. 8, n. 6, p. 662-673, 2005. 
ANNEX I

Codebook

1) Text Characteristics

[YEAR OF PUBLICATION]

[1997]

[1998]

[1999]

[2000]

[2001]

[2002]

[2003]

[2004]

[2005]

[2006]

[2007]

[2008]

[2009]

[2010]

[2011]

[2012]

[2013]

[2014]

[2015]

[2016]

[2017]

\section{[LITERATURE SOURCE]}

[Scientific Literature]

[Metodological Approach]

[Case Study]

[Experiment] 
[Model]

[Projects Review]

[Theoretical Review]

[Organisation's Documents]

[Document Type]

[Book]

[Book Chapter]

[Brochure]

[Conference Proceedings]

[Dicussion Paper]

[Leaflets]

[Papers]

[Policy Briefs]

[Proceedings of Symposium]

[Report]

[Working Paper]

[Workshop Paper]

[Metodological Approach]

[Case Study]

[Projects Review]

[Theoretical Review]

\section{[LOCATION]}

[Study Area]

[Africa]

[Argentina]

[Asia]

[Australia]

[Austria]

[Brazil] 
[Caribean]

[Central America]

[Chile]

[China]

[Colombia]

[Ecuador]

[Ethiopia]

[France]

[Ghana]

[Global]

[India]

[Indonesia]

[Japan]

[Kenya]

[Korea]

[Laos]

[Latin America]

[Madagascar]

[Malawi]

[Malaysia]

[Mexico]

[Nouthern Europe]

[Peru]

[Philippines]

[Puerto Rico]

[Rwanda]

[Russia]

[Scandinavia]

[South Asia]

[Southern Europe]

[Spain] 
[Sweden]

[Tanzania]

[Uganda]

[USA]

[UK]

[Vietnam]

[West Africa Sahel]

[Publication]

[Australia]

[Austria]

[Brazil]

[Canada]

[China]

[Ecuador]

[Estonia]

[France]

[Europe]

[Finland]

[Germany]

[Indonesia]

[Italy]

[Japan]

[Kenya]

[Korea]

[Mexico]

[Netherlands]

[New Zealand]

[Singapore]

[Spain]

[Sweden] 
[Switzerland]

[Tanzania]

[Thailand]

[UK]

[USA]

[RESTORATION] How different authors define restoration according to FLR approach

[Recovery of degraded ecosystem - SER]

[Reference Ecosystem]

[Functions and Biodiversity] "All of the key ecological processes and functions are re-established and all of the original biodiversity is re-established." (Glossary definitions IUCN)

[Social Benefits]

[LANDSCAPE] How different authors define landscape according to FLR approach

[Geographical Mosaic] "A geographical mosaic composed of interacting ecosystems resulting from the influence of geological, topographical, soil, climatic, biotic and human interactions in a given area" (Glossary definitions IUCN)

[Integrated Approach]

[Social Approach]

[SCALE]

[Scale - Definition]

[Scale - Variations]

[FOREST LANDSCAPE] How different authors define forest landscape according to FLR approach

[Forest] 
[Forest Landscape] e.g. "A landscape that is naturally capable of supporting forests, woodlands, or tree canopy cover of 10 percent or more. At one end of the spectrum, the landscape has 100 percent tree canopy cover; at the other end, the landscape has 10 percent tree canopy cover and the rest is composed of grasses and/or shrubs." (HANSON et al., 2015).

[FLR]

[FLR - Definition] How different authors define FLR approach

[Process] e.g. "'a process that aims to regain ecological integrity and enhance human well-being in deforested or degraded forest landscape". The definition implies that FLR is a considered process and not simply a series of ad hoc treatments that eventually cover large areas". "It is about a "process" because it typically takes a long time for a forest landscape to recover, although some of the ecological functions and human benefits provided by restoration may appear early on". Hanson, C., Buckingham, K., DeWitt, S., \& Laestadius, L. (2015). The restoration diagnostic. Washington, DC: WRI.

[Ecological functionality]

[Ecological Integrity] e.g. "maintaining the diversity and quality of ecosystems, and enhancing their capacity to adapt to change and provide for the needs of future generations" (MANSOURIAN; VALLAURI, 2005)

[Human well-being]

[Historically] Does FLR aims to restore the landscape into historical conditions?

[Participatory process]

[Productive functions]

[Mix of land uses practices]

[Multifunctional landscape]

[FLR - Term] How different authors name the FLR approach

[Forest AND landscape restoration]

[Forest landscape restoration]

[Forest restoration in landscapes]

[Restoration of forest landscapes]

[Restoration of forest and landscapes]

[Large-scale forest restoration]

[Landscape restoration] 
[FLR - Policy Driver]

[Advocacy]

[Economic analysis]

[Economic incentives]

[Codes of practice]

[FLR - Challenges and Obstacles]

[Conceptual challenges]

[Technical challenges]

[Governance challenges]

[Practice challenges]

\section{[IMPORTANCE]}

[Conflict resolution] for different land uses

[Social benefits]

[Economic benefits]

[Ecological benefits]

[International agreements] Governments

[Social responsibility] Actions promoted by companies

3) Principles, Criteria and Indicators

[CHARACTERISTICS] Based on the main FLR characteristics, we will identify principles and criteria, according to our definition

\section{[ECOLOGICAL OUTCOMES]}

[Landscape attributes]

[P - Landscape Configuration and Changes]

[C - Composition] i.e. quality: species diversity, endemic species, habitats

diversity]

[I - Assessment of changes in vegetation

[I - Assessment of changes in fauna diversity] 
[C - Structure] quantity: connectivity, fragments size and shape

[I - Assessment of changes in forest connectivity]

[I - Assessment of changes forest cover area]

[C - Heterogeneity] forest, agriculture, remain ecosystems

$$
\text { [I - Assessment of changes in land uses] }
$$

[C - Landscape functions] Flow of species and elements (energy, disturbance), connectivity, permeability

[C - Landscape Multifunctionality] e.g. "Landscapes and their components have multiple uses and purposes, each of which is valued in different ways by different stakeholders" http://www.wri.org/ourwork/project/african-restoration-100/10-principleslandscape-approach

[P - Biodiversity Conservation]

[C - Use of Native Species]

[C - Use of Exotic Species]

[C - Control of Superabundant and Invasive Species]

[C - Habitat maintenance]

[C - Protect threatened and endangered species]

[P - Improvement of Physical aspects]

[C - Climate Change]

[I - Changes in pollution levels]

[C - Reducing Erosion]

[I - Changes in soil structure]

[C - Nutrient Cycling]

[P - Ecosystem Services]

[C - Carbon stock]

[C - Pollination]

[C - Natural Pest Control]

[C - Ecotourism]

[C - Increase of Water Resources]

[I - Plans to maintain water quality] 
[HUMAN DIMENSIONS AND CAPITAL OUTCOMES]

\section{[Institutional Capital]}

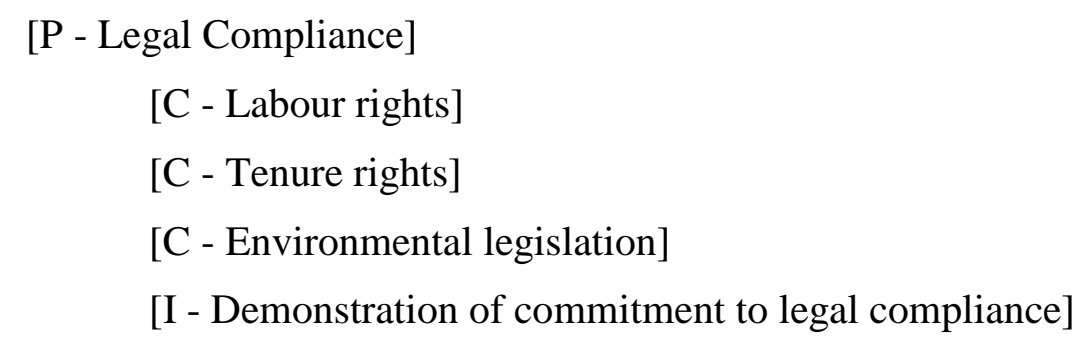

\section{[Human and Social Capital]}

[P - Improvement of local livelihoods]

[P - Participation or engagement]

[C - Traditional Knowledge]

[C - Conflict resolution]

[C - Social cohesion]

[C - Participatory process]

[C- Governance $]$

\section{[Economic and financial Capital]}

[P - General and Subjective well-being]

[C - Non-material Benefits] e.g. cultural, recreational, religious, tourism, pride

$$
\begin{aligned}
& \text { [I - Self-perception about well-being level] } \\
& \text { [I - Recreational opportunities] }
\end{aligned}
$$

[C - Gender Equity] restoration activities benefits women because they gain new training, capacitation and job opportunities. Empowerment.

[C - Food and Health Security]

[P - Economic Diversification]

[C - Income - monetary] i.e. access to monetary income from wood, non-timber forest products, fish, wild meat

[I - Assessment of changes in Income Level]

[C - Income - non-monetary] i.e. access to consumption of wood, non-timber forest products, fish, wild meat

[I - Assessment of changes in Income Level] 


$$
\begin{gathered}
\text { [C - Access to credit and to infrastructure }] \\
{[\mathrm{I}-\text { Assessment of changes in the level of access }} \\
\text { to credit }] \\
{[\mathrm{P}-\text { Capacitation }]} \\
{[\mathrm{C}-\text { Training, Capacitation and Access to information }]} \\
{[\mathrm{I}-\text { Documentation of training and capacitation }]} \\
\text { [C - Employment Conditions }] \\
{[\text { I - Access to employment }]}
\end{gathered}
$$

\section{[INTERVENTIONS]}

$$
\begin{aligned}
& {[\mathrm{P}-\text { Interventions - Planning }]} \\
& {[\mathrm{C}-\text { Management Planning }]} \\
& {[\mathrm{C}-\text { Workshops, discussions and interviews }]} \\
& {[\mathrm{C}-\text { Schedule of activities }]} \\
& {[\mathrm{C}-\text { Investments / Financing }]} \\
& {[\mathrm{C}-\text { Hiring and Partnerships }]} \\
& {[\mathrm{C}-\text { Multidisciplinary }]} \\
& {[\mathrm{C}-\text { Defining Scope }]} \\
& {[\mathrm{C}-\text { Impacts and trade-offs assessment }]}
\end{aligned}
$$

[C - Landscape Delimitation]

[C - Geographically]

[C - Multiple Land Uses]

[C - Land Tenure]

[C - Forest Model - GIS]

[C - LANDIS Model]

[C - Field Data Collection]

[C - Use of spatial software]

[C - Human Interaction]

[C - Models $]$

[C - Priority Location and Strategies]

[C - Priority Locations and Strategies - Ecological]

[I - Use of spatial data]

[I - Simulation Methods]

[C - Priority Locations and Strategies - Socioeconomic] 


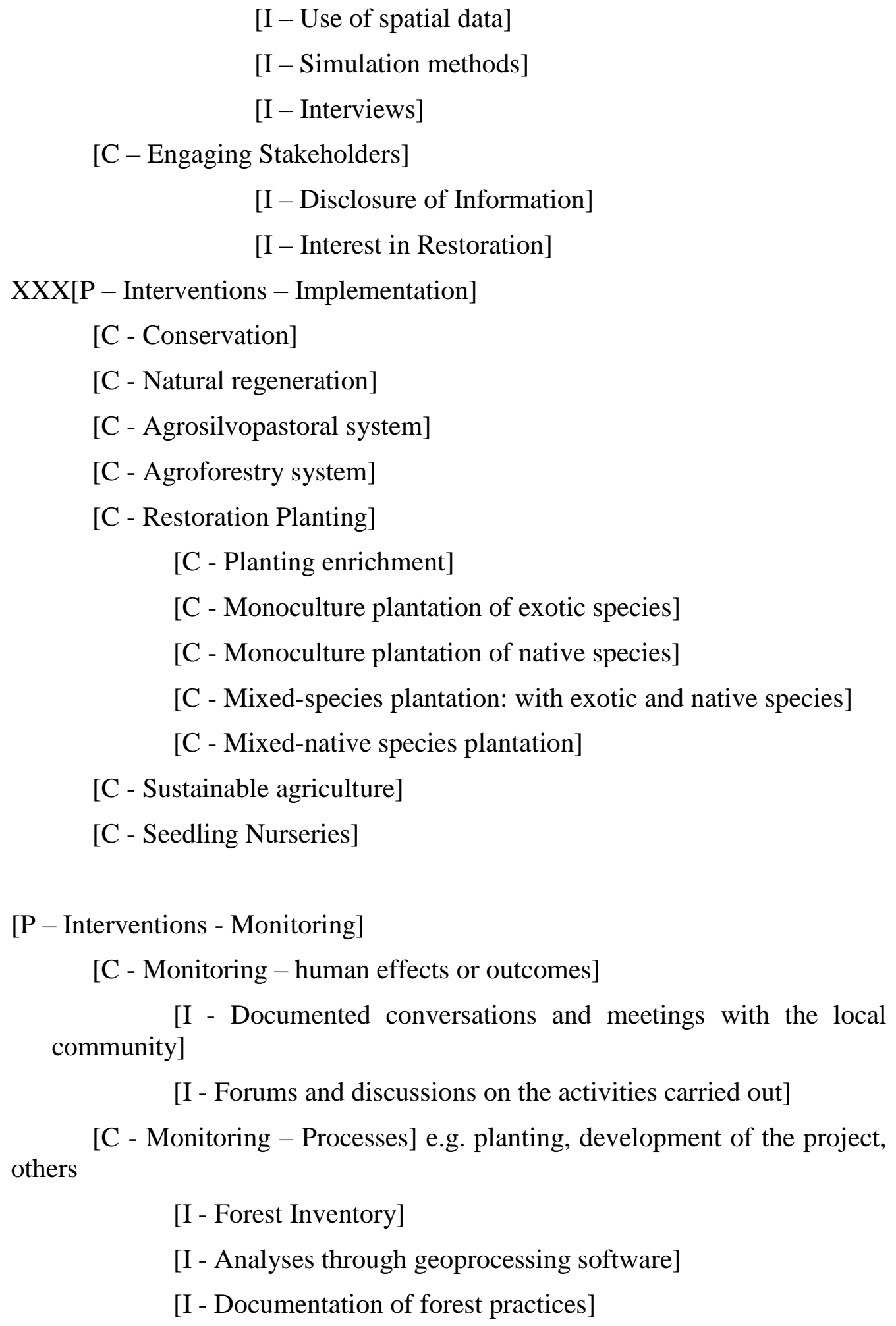

[I - Documented conversations and meetings with the local

[I - Forums and discussions on the activities carried out] [C - Monitoring - Processes] e.g. planting, development of the project, others

[I - Forest Inventory]

[I - Analyses through geoprocessing software]

[I - Documentation of forest practices] 


\section{ANNEX II - Interview Protocol (Project Managers)}

\section{INTRODUÇÃO PARA AS ENTREVISTAS (IMPRIMIR SOMENTE UMA VEZ)}

\section{Olá,}

Meu nome é e estou realizando uma pesquisa para a Universidade de São Paulo - USP. Nossa intenção com essa pesquisa é entender melhor sobre as atividades de restauração das matas e das paisagens aqui no Pontal do Paranapanema, que foram planejadas e implementadas por este Instituto.

Nossa intenção é identificar quais critérios foram usados para o planejamento e a implementação do projeto, ou seja, como é realizada a gestão do projeto, quais pessoas foram envolvidas, como a área de restauração foi selecionada, como as atividades implementadas foram escolhidas, dentre outros aspectos. Com isso, buscamos entender os desafios de implementação, assim como os resultados positivos e o que poderia ser melhorado, tanto neste quanto em novos projetos de restauração. Essas entrevistas, combinadas com aquelas dos participantes podem, portanto, contribuir com informações relevantes para melhorar a atuação dos gestores de projetos aqui e em outros locais.

Faremos também entrevistas com os proprietários dos locais onde as atividades de restauração foram implementadas, para entender como estas foram feitas, quem participou, quais atividades as pessoas ainda realizam na área, quais os resultados dessas atividades, dentre outros assuntos.

Peço a gentileza de saber se eu poderia conversar com a pessoa deste Instituto que foi a principal responsável pela gestão do planejamento e implementação do projeto de restauração de florestas e paisagens.

Essa conversa deve levar em torno de minutos. Gostaríamos de pedir autorização para gravar esta conversa. Isso ajudará a sermos mais rápidos e a lembrarmos exatamente o que foi dito e considerado importante. Não mostraremos a gravação a ninguém e os arquivos serão apagados depois que finalizarmos o estudo. O nome de quem forneceu a informação também será excluído para manter a confidencialidade das informações.

Além disso, gostaria de lhe entregar um Termo de Consentimento. É um documento que explicita as informações que acabei de passar, além de resumir os objetivos desta entrevista. Nele também constam os contatos dos responsáveis pelo projeto, contatos caso você tenha alguma dúvida no futuro referente ao estudo. Este Termo é feito em duas vias iguais: a via que estou lhe entregando já está assinada por mim e ficará guardada com você, a outra via ficará arquivada comigo e para que tenha validade, preciso que você, por gentileza, assine no local indicado. 


\begin{tabular}{|c|c|}
\hline $\begin{array}{lll}\text { PROCAM, } & & \text { IEE, } \\
\text { UNIVERSIDADE } & \text { DE } & \text { SÃO } \\
\text { PAULO } & & \\
\text { Projeto We Forest } & & \\
-2019 & & \end{array}$ & 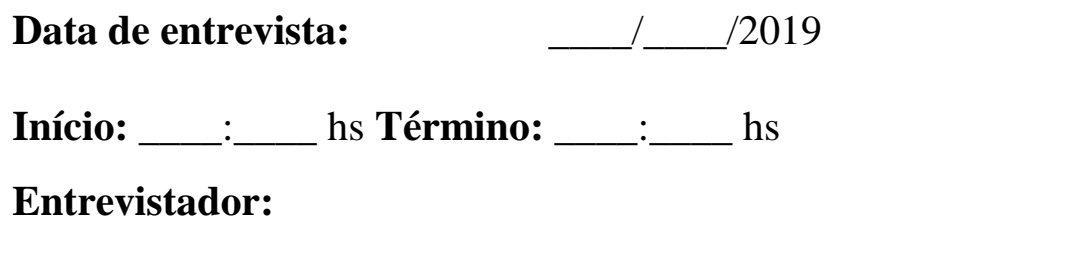 \\
\hline \multirow[b]{2}{*}{$\begin{array}{l}\text { GESTORES DOS } \\
\text { PROJETOS DE } \\
\text { RESTAURAÇÃO }\end{array}$} & Nome \\
\hline & $\begin{array}{l}\text { Gênero: [ ] F [ ] } \\
\text { Contato } \\
\text { entrevistado: } \\
\text { Local } \\
\text { Entrevista: }\end{array}$ \\
\hline
\end{tabular}

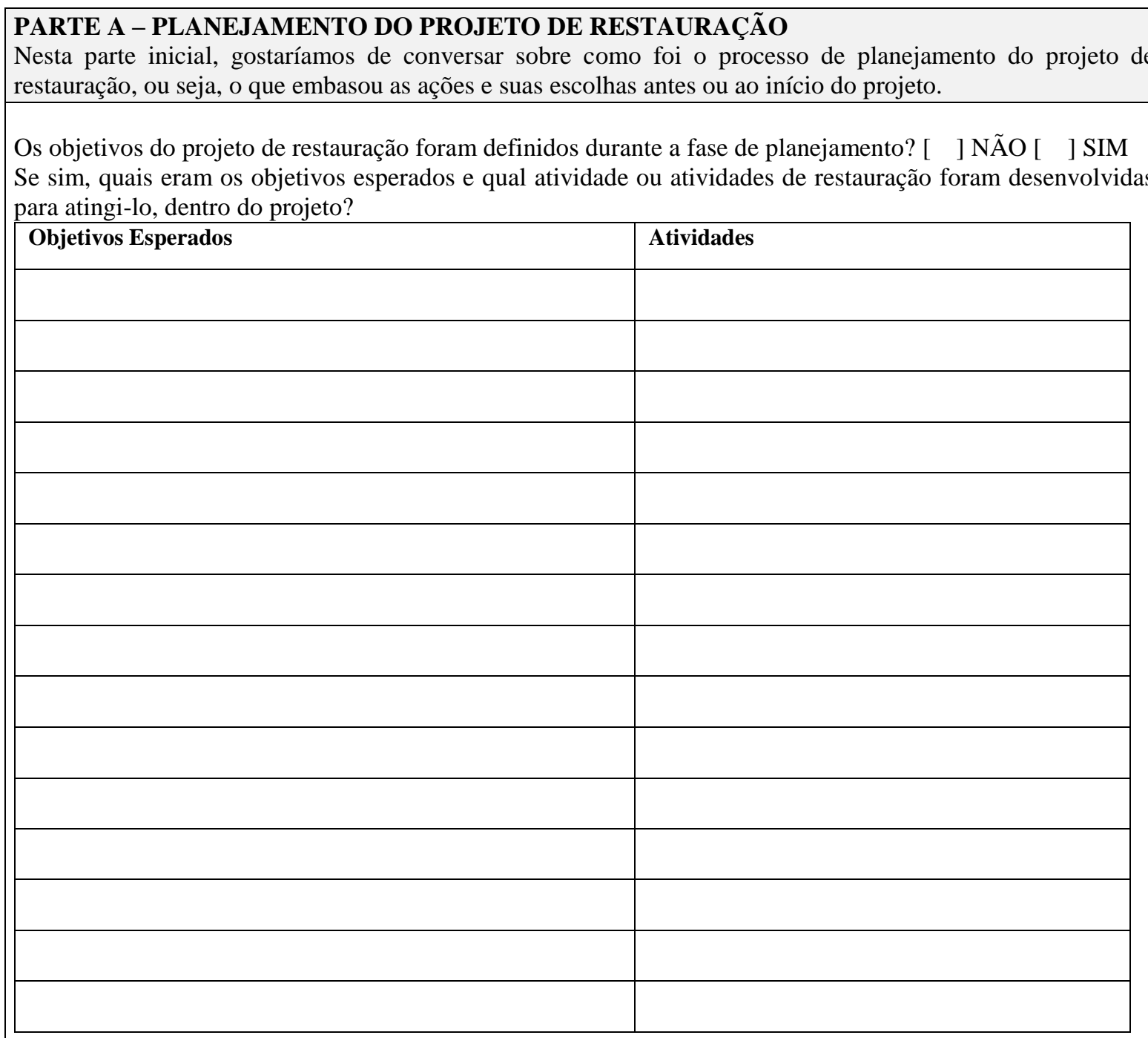

Para caracterizar e auxiliar na seleção da área da paisagem ou paisagens na região que sofreriam intervenções de restauração, foram utilizados programas de geoprocessamento como auxiliares ou outras formas de mapeamento e caracterização espacial, como, por exemplo, seria o caso de mapeamento participativo?

Geoprocessamento: [ ] NÃO [ ] SIM

Outras formas: [ ] NÃO [ ] SIM -

Quais? 1)

2) 


\begin{tabular}{|l|l|}
\hline $\begin{array}{l}\text { Se sim, quais aspectos ou variáveis do ambiente geográfico, } \\
\text { físico e ecológico foram incorporados na espacialização da } \\
\text { paisagem por meio desses métodos? }\end{array}$ & $\begin{array}{l}\text { E houve algum aspecto humano ou } \\
\text { socioeconômico que foi } \\
\text { considerado? Quais? }\end{array}$ \\
\hline 1$)$ & $1)$ \\
\hline 2$)$ & $2)$ \\
\hline 3$)$ & $3)$ \\
\hline 4$)$ & $4)$ \\
\hline 5$)$ & $5)$ \\
\hline 6$)$ & $6)$ \\
\hline 7$)$ & $7)$ \\
\hline
\end{tabular}

Como forma de checar alguns aspectos particulares, nesta parte, eu gostaria de saber se na delimitação da área da paisagem em que seriam realizadas intervenções para a restauração foram levantadas informações sobre e identificados de alguma forma os seguintes aspectos que eu vou falar:

\begin{tabular}{|c|c|c|}
\hline Aspecto & Foi considerado? Se sim, quais aspectos? & Como foram consideradas? \\
\hline $\begin{array}{l}\text { Características geográficas } \\
\text { em termos físicos, como por } \\
\text { exemplo, características do } \\
\text { relevo ou presença de corpos } \\
\text { d'água }\end{array}$ & [ ] NÃO [ ] SIM. Quais? & \\
\hline $\begin{array}{l}\text { Características ecológicas, } \\
\text { como cobertura e tipo de } \\
\text { vegetação, assim como da } \\
\text { paisagem, por exemplo, } \\
\text { aspectos da conectividade e } \\
\text { corredores, dentre outros }\end{array}$ & [ ] NÃO [ ] SIM. Quais características? & \\
\hline Características relativas ao & [ ] NÃO [ ] SIM. Quais características? & \\
\hline
\end{tabular}




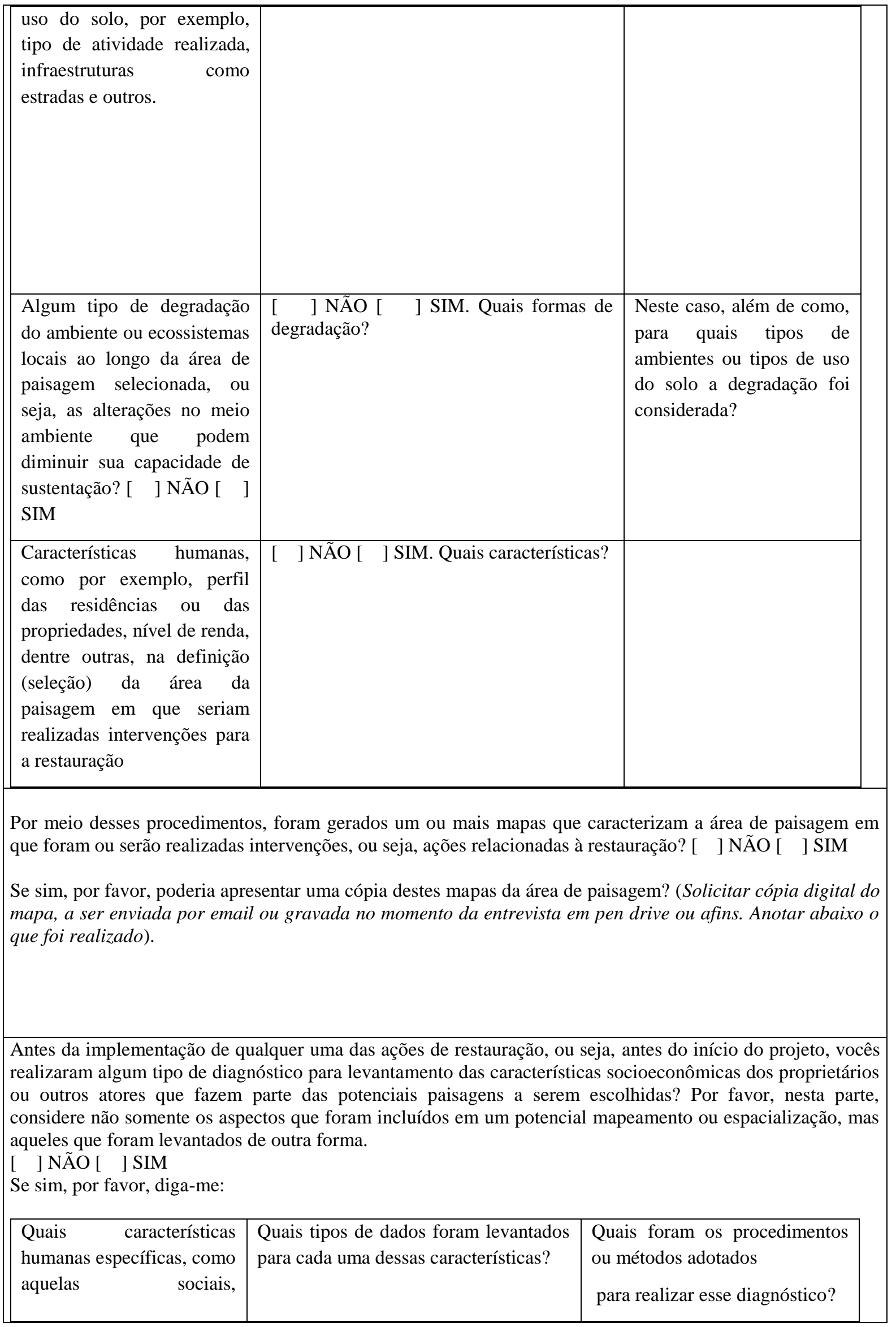




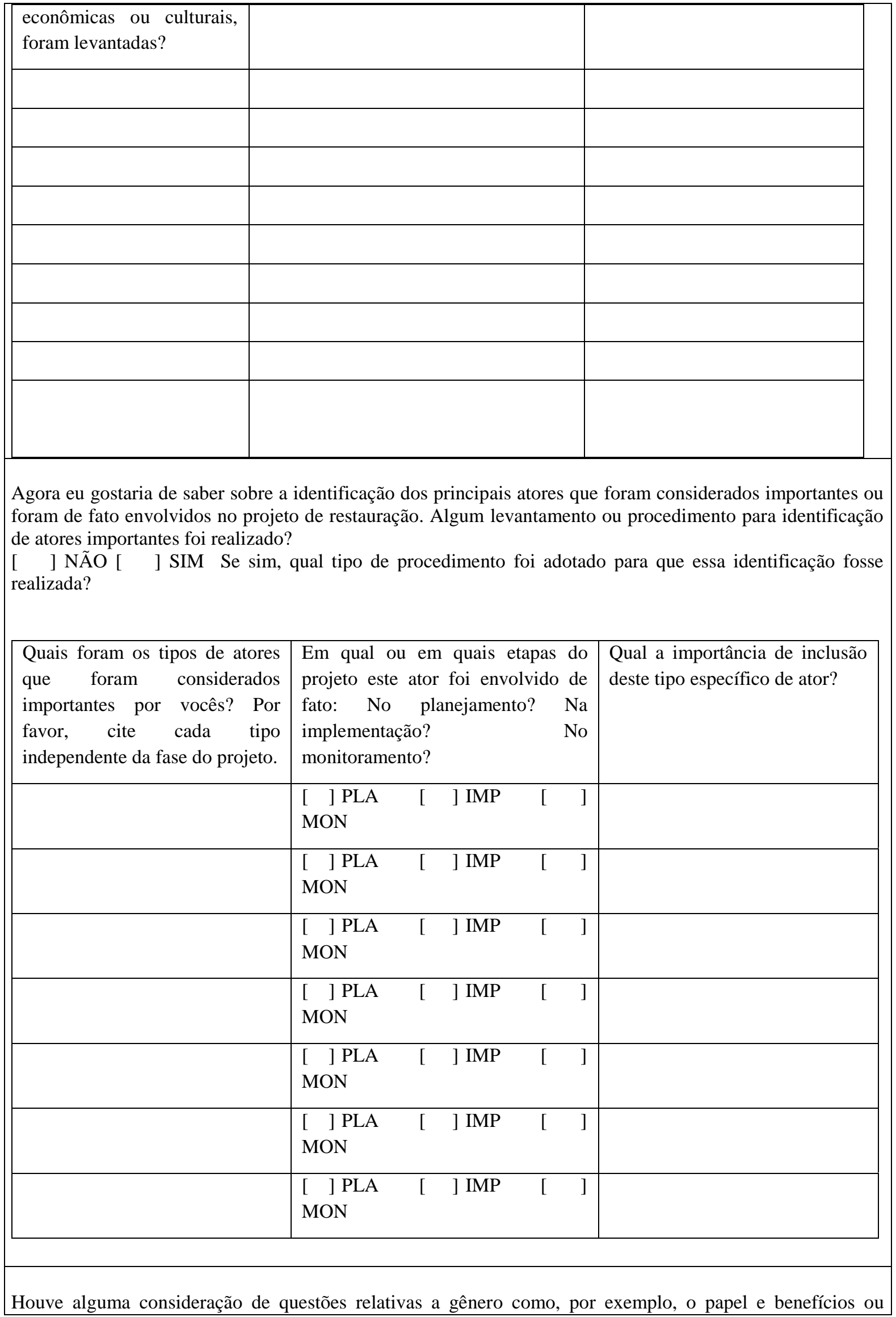


malefícios dos projetos de restauração para as mulheres ou outros grupos minoritários?

[ ] NÃO [ ] SIM Se sim, por favor responda.

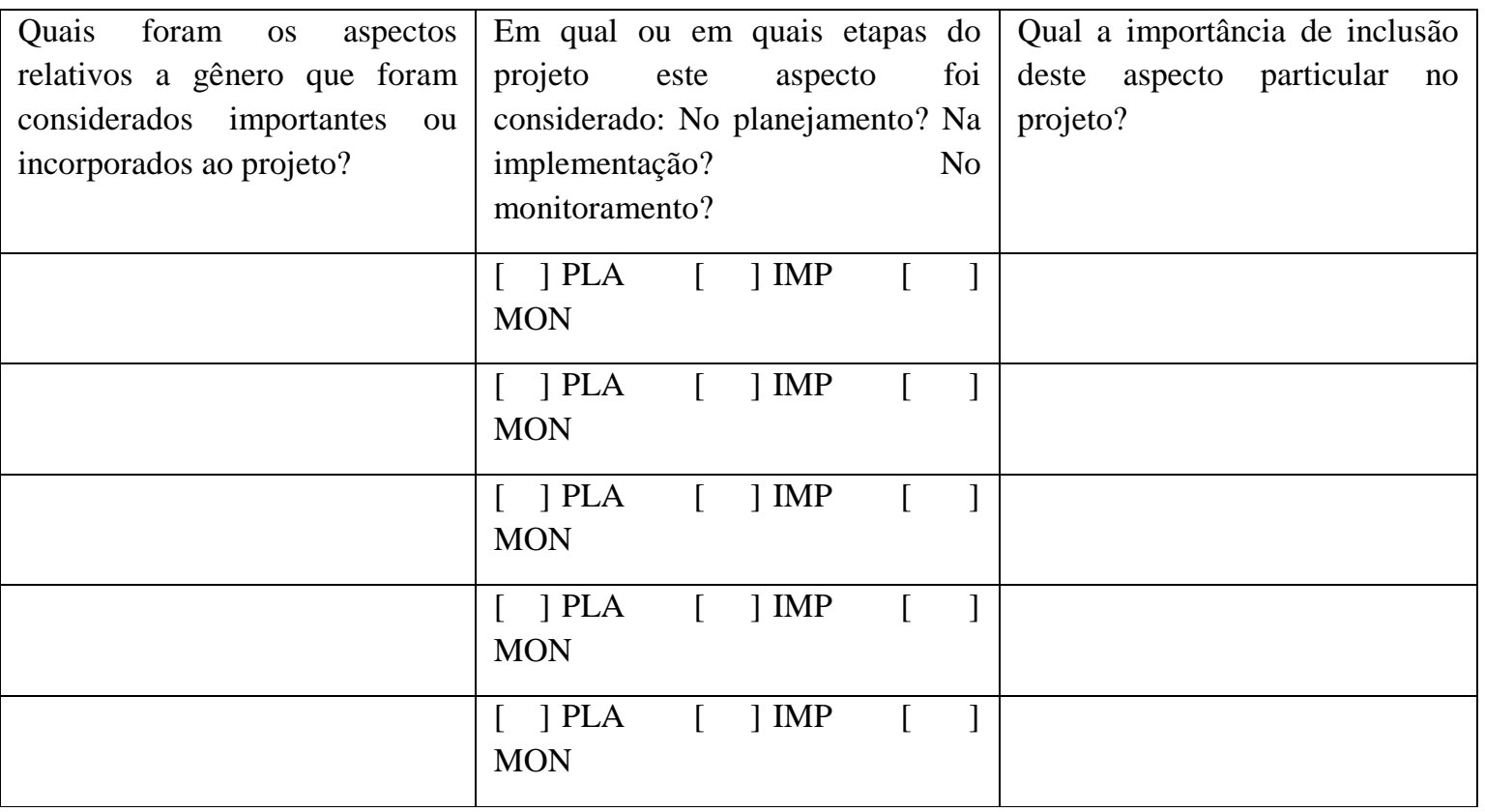

Houve alguma consideração de questões relativas a jovens ou crianças como, por exemplo, o envolvimento deles tanto em termos de trabalho, quando em outros aspectos?

[ ] NÃO [ ] SIM Se sim, por favor responda.

\begin{tabular}{|c|c|c|}
\hline $\begin{array}{l}\text { Quais foram os aspectos } \\
\text { relativos aos jovens ou crianças } \\
\text { que foram considerados } \\
\text { importantes ou incorporados ao } \\
\text { projeto? }\end{array}$ & $\begin{array}{l}\text { Em qual ou em quais etapas do } \\
\text { projeto este aspecto foi } \\
\text { considerado: No planejamento? Na } \\
\text { implementação? } \\
\text { monitoramento? }\end{array}$ & $\begin{array}{l}\text { Qual a importância de inclusão } \\
\text { deste aspecto particular no } \\
\text { projeto? }\end{array}$ \\
\hline & $\begin{array}{l}\text { [ ] PLA [ ] IMP }[\text { [ ] } \\
\text { MON }\end{array}$ & \\
\hline & $\begin{array}{l}{[\quad] \text { PLA }} \\
\text { MON }\end{array}$ & \\
\hline & $\begin{array}{l}{[\quad] \text { PLA }} \\
\text { MON }\end{array}$ & \\
\hline & $\begin{array}{l}\text { [ ] PLA [ ] IMP }[\text { [ ] } \\
\text { MON }\end{array}$ & \\
\hline & $\begin{array}{l}\text { [ ] PLA }[\text { ] IMP } \\
\text { MON }\end{array}$ & \\
\hline
\end{tabular}

Existe um cronograma que contemplando as datas previstas para a realização de cada uma das atividades idealizadas como necessárias ao projeto de restauração? 


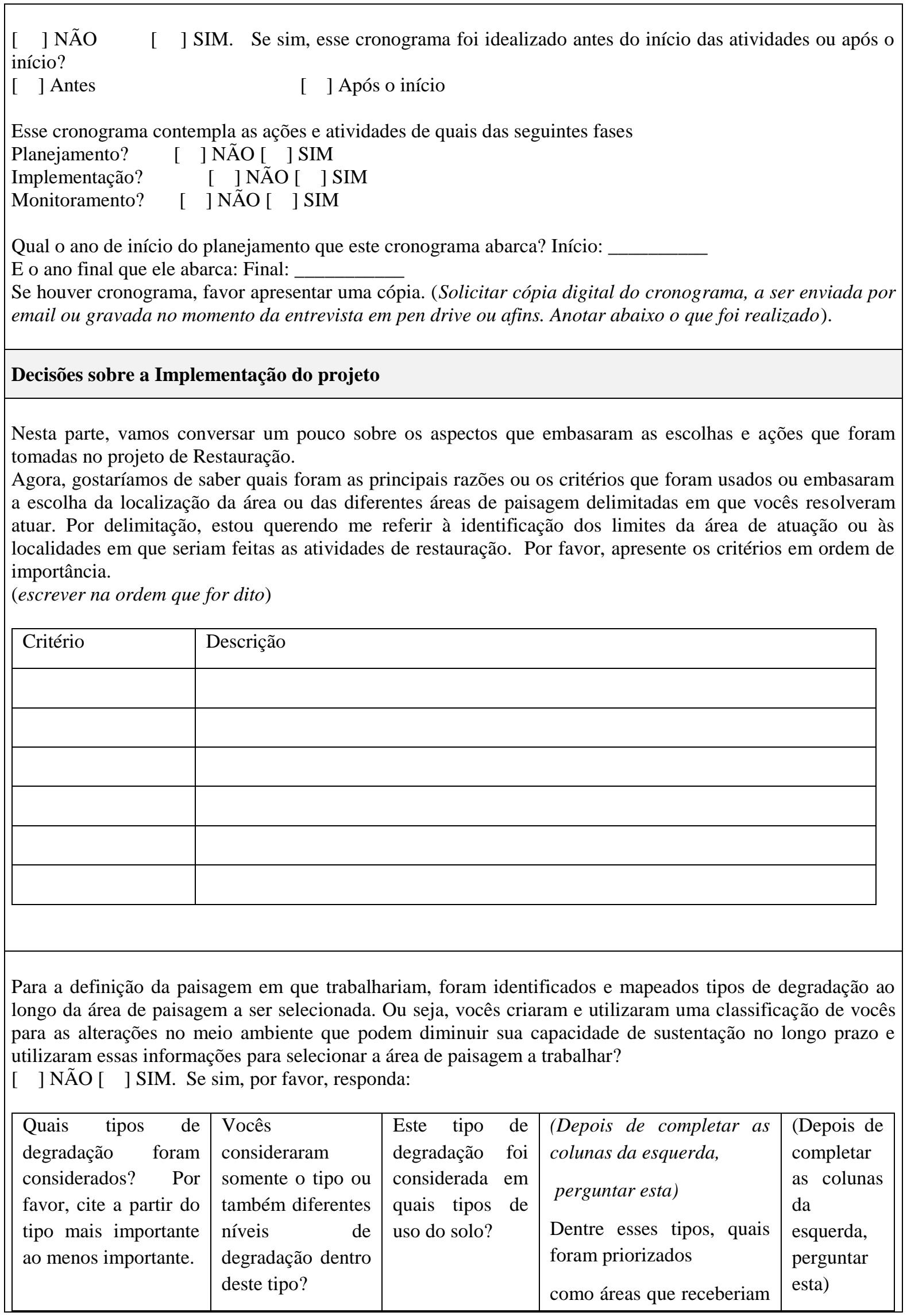




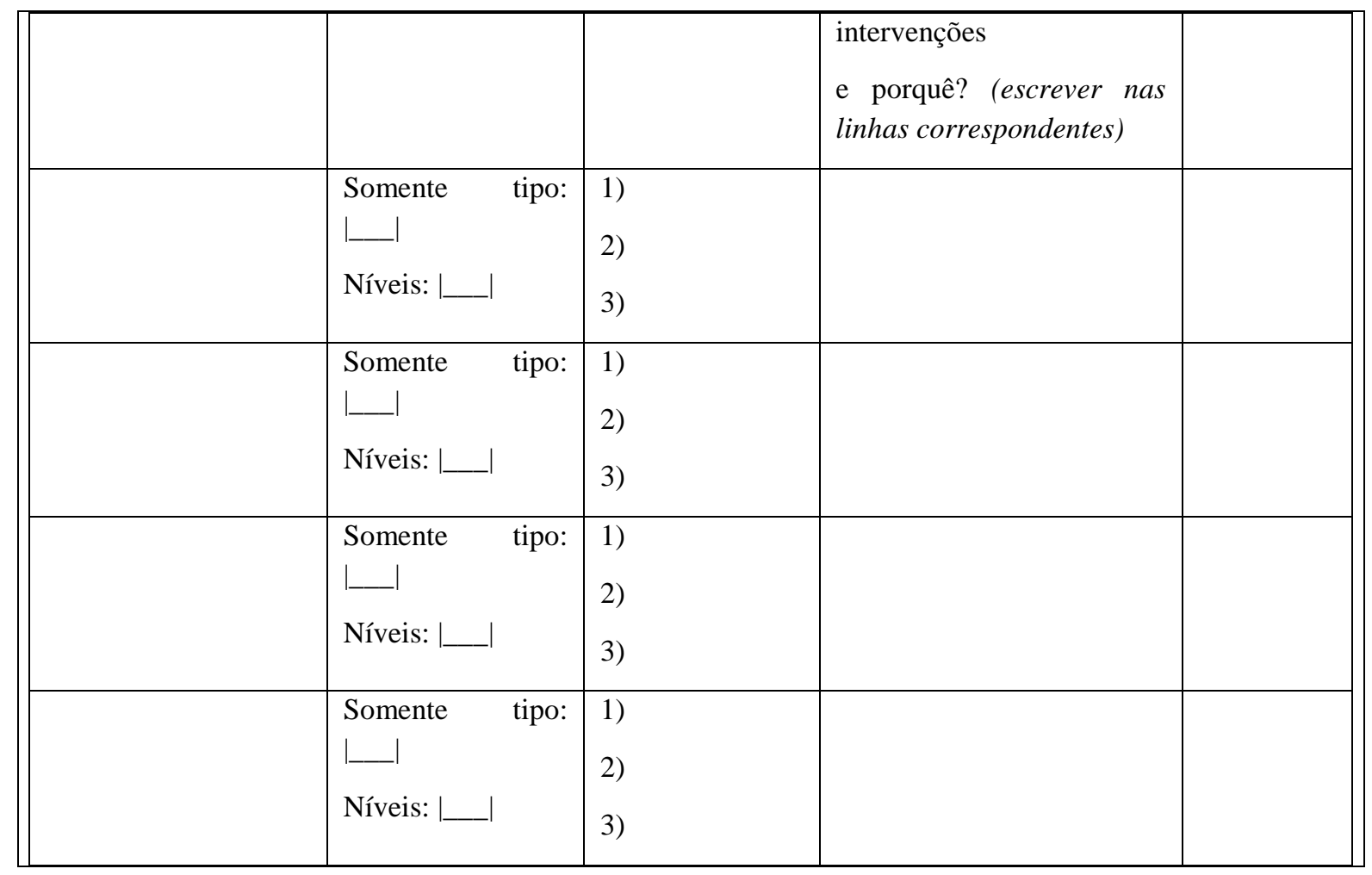

A área ou áreas de paisagem selecionadas para fazerem o projeto de restauração possui mais de um tipo de uso do solo, ou seja, inclui variados usos humanos ou características naturais? [ ] NÃO [ ] SIM

\begin{tabular}{|l|l|}
\hline $\begin{array}{l}\text { Se sim, quais tipos de uso humanos do solo são encontrados na } \\
\text { ára de paisagem? }\end{array}$ & $\begin{array}{l}\text { Se sim, quais tipos de cobertura natural } \\
\text { existem na área de paisagem } \\
\text { selecionada? }\end{array}$ \\
\hline 1$)$ & $1)$ \\
\hline 2$)$ & $2)$ \\
\hline 3$)$ & $3)$ \\
\hline 4$)$ & $4)$ \\
\hline 5$)$ & $5)$ \\
\hline 6$)$ & $6)$ \\
\hline 7$)$ & $7)$ \\
\hline 8$)$ & $8)$ \\
\hline
\end{tabular}

A área de paisagem selecionada é formada por mais de uma propriedade? [ ] NÃO [ ] SIM

Se sim, poderia, por favor, identificar quantas propriedades de cada tipo foram incluídas ao longo de todo o período do projeto? Para caracterizar o tipo, por favor, pense no uso ou nos tipos de usos dominantes em cada propriedade. Por exemplo, 2 propriedades com monocultura de cana-de-açúcar. Além disso, considere também aquelas que abandonaram o projeto.

(Caso o entrevistado não consiga lembrar, peça se poderia fornecer as informações depois e anote para cobrar). 


\begin{tabular}{|l|l|}
\hline Tipo de Uso & Quantidade de cada \\
\hline 1) & \\
\hline 2) & \\
\hline 3$)$ & \\
\hline 4$)$ & \\
\hline 5) & \\
\hline 6$)$ & \\
\hline 7) & \\
\hline 8$)$ & \\
\hline & \\
\hline
\end{tabular}




\section{PARTE B - DEFINIÇÃO DE ESTRATÉGIAS E ÁREAS DE IMPLEMENTAÇÃO}

Nesta segunda parte, gostaríamos de conversar sobre como foi o processo de decisão sobre as estratégias de restauração adotadas, bem como a escolha do local onde estas estratégias foram implementadas, e quem participou desta implementação.

\section{INTERVENÇÕES ECOLÓGICAS OU NO AMBIENTE BIOFÍSICO \\ Quais os tipos de intervenções, ou seja, atividades visando a restauração da paisagem biofísica foram selecionadas para serem realizadas no projeto de restauração? Eu vou falar uma lista e gostaria me dissesse se sim ou não:}

\begin{tabular}{|c|c|c|}
\hline (Ler lista) & Realizado? & $\begin{array}{l}\text { Qual o número aproximado } \\
\text { de pessoas que participaram } \\
\text { desde o início do projeto nesta } \\
\text { atividade? }\end{array}$ \\
\hline $\begin{array}{l}\text { Conservação de remanescentes florestais } \\
\text { Quais atividades de conservação foram realizadas? } \\
\text { 1)___ } \\
\text { 3)_ }\end{array}$ & [ ] ] NÃO [ ] SIM & \\
\hline $\begin{array}{l}\text { Regeneração Natural passiva, ou seja, simplesmente não } \\
\text { utilizando as áreas para permitir o crescimento natural. }\end{array}$ & [ ] NÃO [ ] SIM & \\
\hline $\begin{array}{l}\text { Condução de Regeneração Natural, ou seja, por práticas } \\
\text { como controle do fogo, proteção do pisoteamento por } \\
\text { gado, supressão de espécies exóticas invasoras, controle de } \\
\text { herbivoria, limpeza de locais em volta de plântulas, } \\
\text { retirada de trepadeiras, e fertilização das mudas. ou outras } \\
\text { estratégias }\end{array}$ & $\begin{array}{l}\text { [ ] NÃO [ ] SIM. } \\
\text { Quais? } \\
\text { 1) } \\
\text { 2) } \\
\text { 3) } \\
\text { 4) } \\
\text { 5) }\end{array}$ & \\
\hline $\begin{array}{l}\text { Restauração por plantio de mudas nativas, ou seja, de } \\
\text { mudas de árvores que existiam previamente na região }\end{array}$ & [ ] ] NÃO [ ] SIM & \\
\hline $\begin{array}{l}\text { Restauração por plantio de mudas de árvores exóticas, ou } \\
\text { seja, originárias de outros biomas, regiões ou países }\end{array}$ & [ ] ] NÃO [ ] SIM & \\
\hline Restauração por introdução de sistemas agroflorestais & [ ] NÃO [ ] SIM & \\
\hline $\begin{array}{l}\text { Outras Práticas sustentáveis de agricultura além dos } \\
\text { sistemas agroflorestais que não sejam baseadas em } \\
\text { árvores. }\end{array}$ & [ ] NÃO [ ] SIM & \\
\hline Outra? & [ ] N N & \\
\hline Outra? & [ ] NÃO [ ] SIM & \\
\hline
\end{tabular}




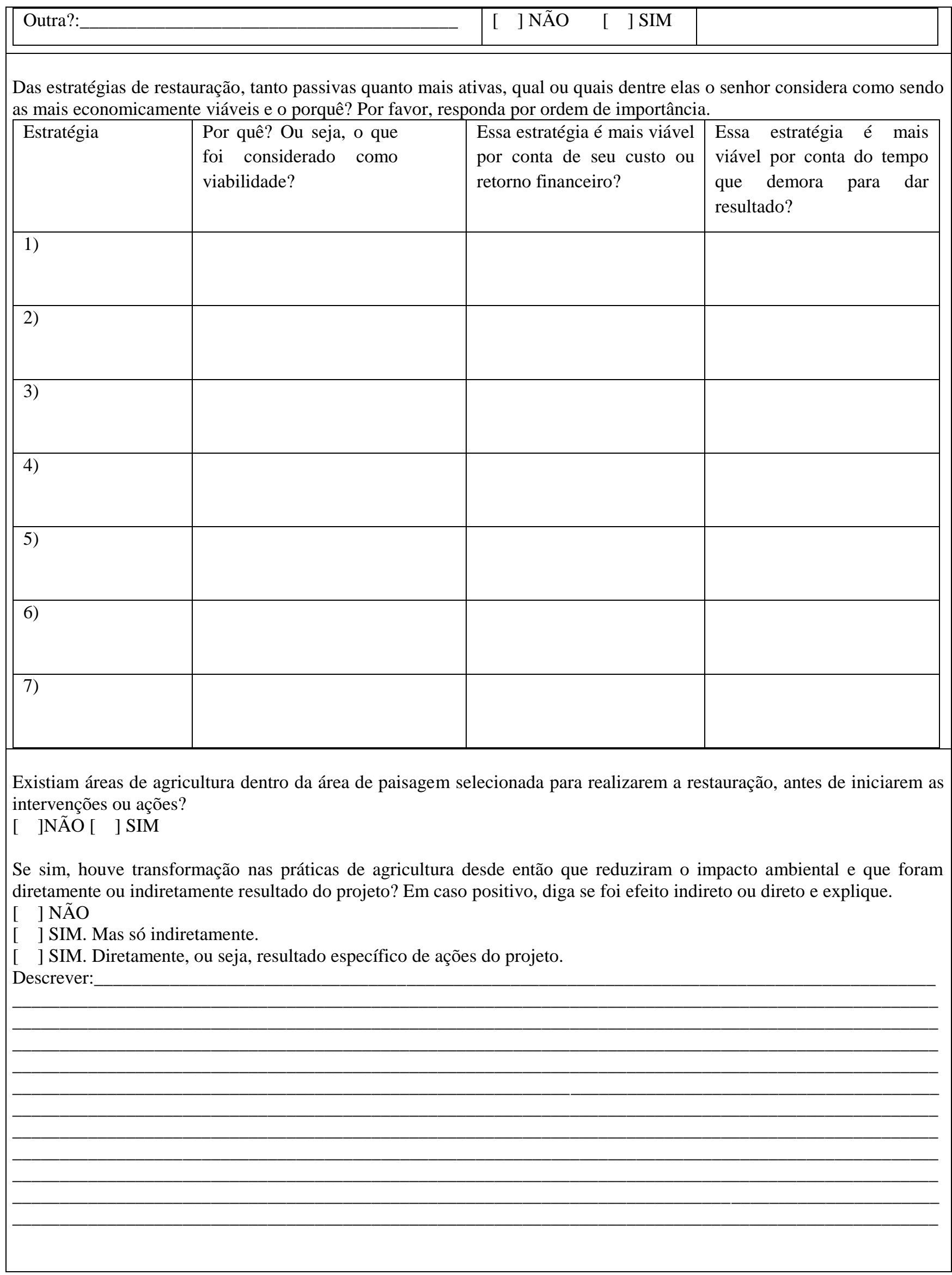


Existiam áreas de pecuária dentro da área de paisagem selecionada, antes de iniciarem as intervenções de restauração? [ ]NÃO [ ] SIM

Se sim, houve transformação nas práticas de pecuária desde então que reduziram o impacto ambiental e que foram diretamente ou indiretamente resultado do projeto? Em caso positivo, diga se foi efeito indireto ou direto e explique.

[ ] NÃO

[ ] SIM. Mas só indiretamente.

[ ] SIM. Diretamente, ou seja, resultado específico de ações do projeto.

Descrever:

\section{INTERVENÇÕES SOCIOECONÔMICAS}

\section{Intervenções gerais}

Foram planejadas e realizadas atividades visando resultados ao bem-estar entendido de forma ampla foram selecionadas para serem realizadas no projeto de restauração?

Eu vou falar uma lista e gostaria me dissesse se sim ou não e como.

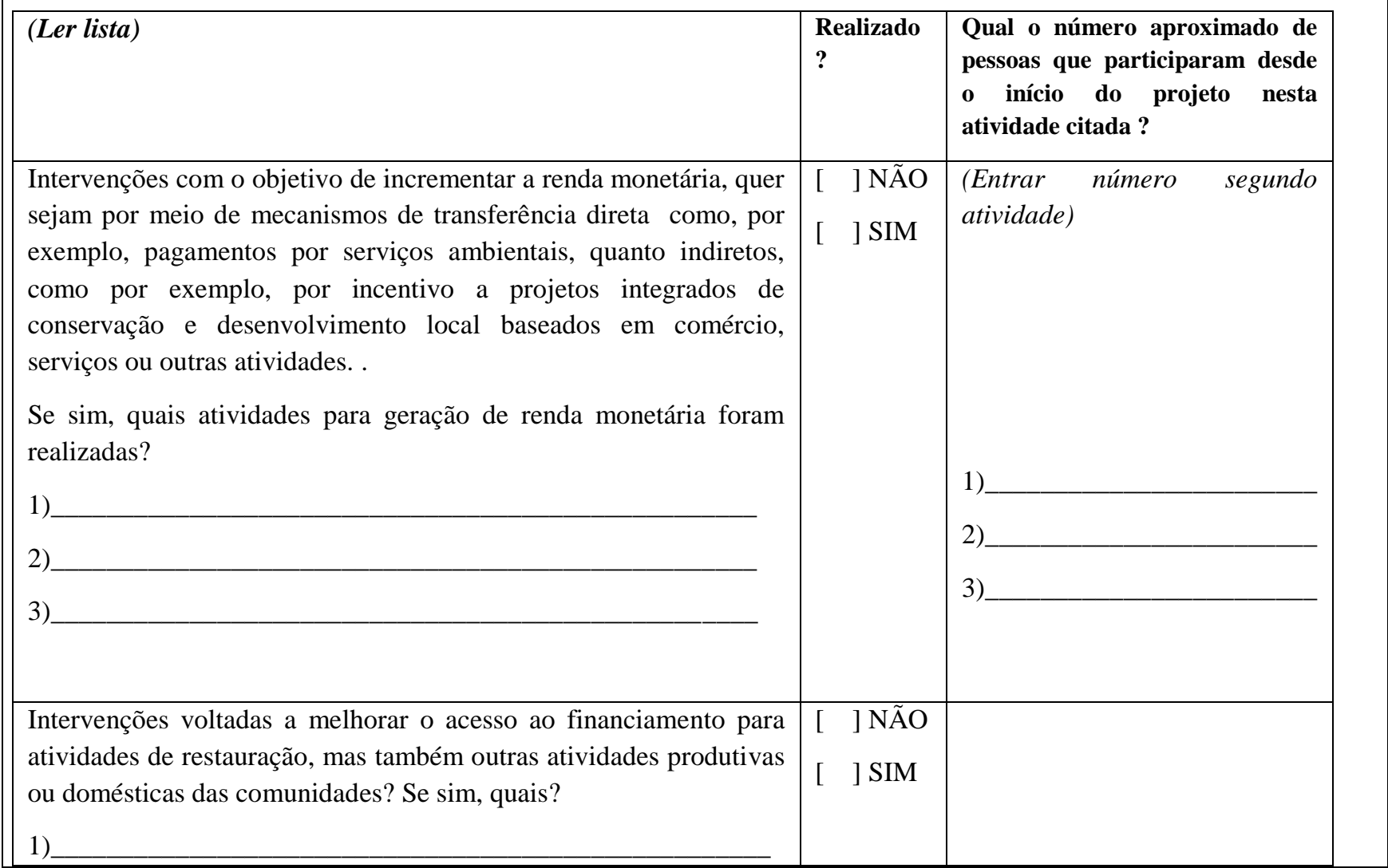




\begin{tabular}{|c|c|c|}
\hline 2) & & $\begin{array}{l}\text { 1) } \\
\text { 2) } \\
\text { 3) }\end{array}$ \\
\hline $\begin{array}{l}\text { Intervenções com o objetivo de capacitar as pessoas da região em } \\
\text { atividades práticas como, por exemplo, em atividades produtivas. } \\
\text { Se sim, quais atividades de capacitação foram realizadas? } \\
\text { 1)___ } \\
\text { 3)___ }\end{array}$ & $\begin{array}{l}{\left[\begin{array}{l}\text { [ } \\
\text { [ }\end{array}\right] \text { SIMO }} \\
\text { SIM }\end{array}$ & 1) \\
\hline $\begin{array}{l}\text { Intervenções com o objetivo de melhorar o nível de informação ou } \\
\text { conhecimento da população em aspectos como, por exemplo, } \\
\text { relativos à restauração, conservação de florestas e outros } \\
\text { ecossistemas. } \\
\text { Se sim, quais atividades de capacitação foram realizadas? } \\
\text { 1)__ } \\
\text { 2)__ } \\
\text { 3) }\end{array}$ & $\begin{array}{l}\text { ] ] NÃO } \\
\text { [ ] SIM }\end{array}$ & 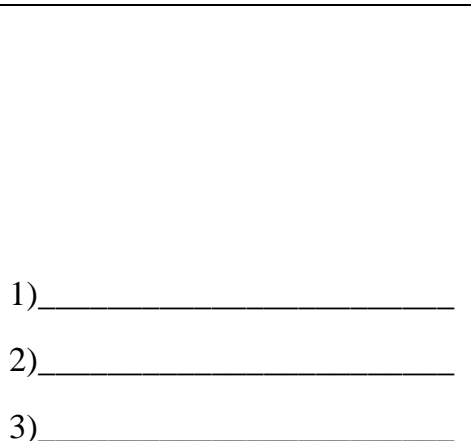 \\
\hline $\begin{array}{l}\text { Intervenções com o objetivo de aumentar o empoderamento, ou } \\
\text { sejam, fomentar o poder de decisão e ação dos membros da } \\
\text { população como um todo, ou então de segmentos específicos dentre } \\
\text { eles como aqueles minoritários. } \\
\text { Se sim, quais atividades de capacitação foram realizadas? } \\
\text { 1)___ } \\
\text { 3) }\end{array}$ & 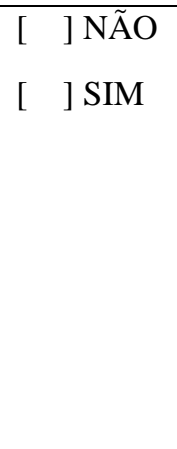 & 1)_ \\
\hline $\begin{array}{l}\text { Intervenções para melhorar a qualidade de vida entendida de } \\
\text { maneira geral e não apenas em termos financeiros da população } \\
\text { residente nas paisagens. } \\
\text { Se sim, quais atividades de capacitação foram realizadas? } \\
\text { 1)__ } \\
\text { 2)_ }\end{array}$ & 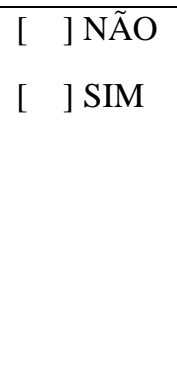 & $\begin{array}{l}\text { 1) } \\
\text { 2) } \\
\text { 3) }\end{array}$ \\
\hline
\end{tabular}




\begin{tabular}{|c|c|c|}
\hline 3) & & \\
\hline $\begin{array}{l}\text { Intervenções voltadas a melhorar o capital social das pessoas dentro } \\
\text { da paisagem como, por exemplo, por meio do incentivo à formação } \\
\text { de grupos formais ou informais, como associações ou redes de } \\
\text { produtores ou de proprietários. } \\
\text { Se sim, quais atividades de capacitação foram realizadas? } \\
\text { 1)___ } \\
\text { 2)_ }\end{array}$ & $\begin{array}{l}{[\text { ] }] \text { NÃO }} \\
{[\text { ] SIM }}\end{array}$ & $\begin{array}{l}\text { 1) } \\
\text { 2) } \\
\text { 3) }\end{array}$ \\
\hline $\begin{array}{l}\text { Intervenções voltadas a melhorar a infraestrutura voltada tanto a } \\
\text { facilitar as ações de restauração, mas também outras atividades das } \\
\text { comunidades dentro da paisagem? } \\
\text { Se sim, quais atividades de capacitação foram realizadas? } \\
\text { 1)__ } \\
\text { 2)__ }\end{array}$ & $\begin{array}{l}\text { [ ] ] NÃO } \\
\text { [ ] SIM }\end{array}$ & 1) \\
\hline $\begin{array}{l}\text { Intervenções voltadas a melhorar a posse de bens produtivos ou não } \\
\text { produtivos por membros da comunidade. } \\
\text { Se sim, quais atividades foram realizadas? } \\
\text { 1) } \\
\text { 2) } \\
\text { 3) }\end{array}$ & $\begin{array}{l}\text { [ ] NÃO } \\
\text { [ ] SIM }\end{array}$ & 1) \\
\hline $\begin{array}{l}\text { Intervenções voltadas a mudar a percepção das pessoas ou } \\
\text { sensibilizá-las acerca da importância da restauração das florestas e } \\
\text { paisagens na região. } \\
\text { Se sim, quais atividades foram realizadas? } \\
\text { 1)___ } \\
\text { 2) }\end{array}$ & $\begin{array}{l}\text { [ ] NÃO } \\
\text { [ ] SIM }\end{array}$ & $\begin{array}{l}1) \\
\text { 2) } \\
\text { 3) }\end{array}$ \\
\hline Intervenções voltadas a mudar a intenção comportamental e & [ ] NÃO & \\
\hline
\end{tabular}




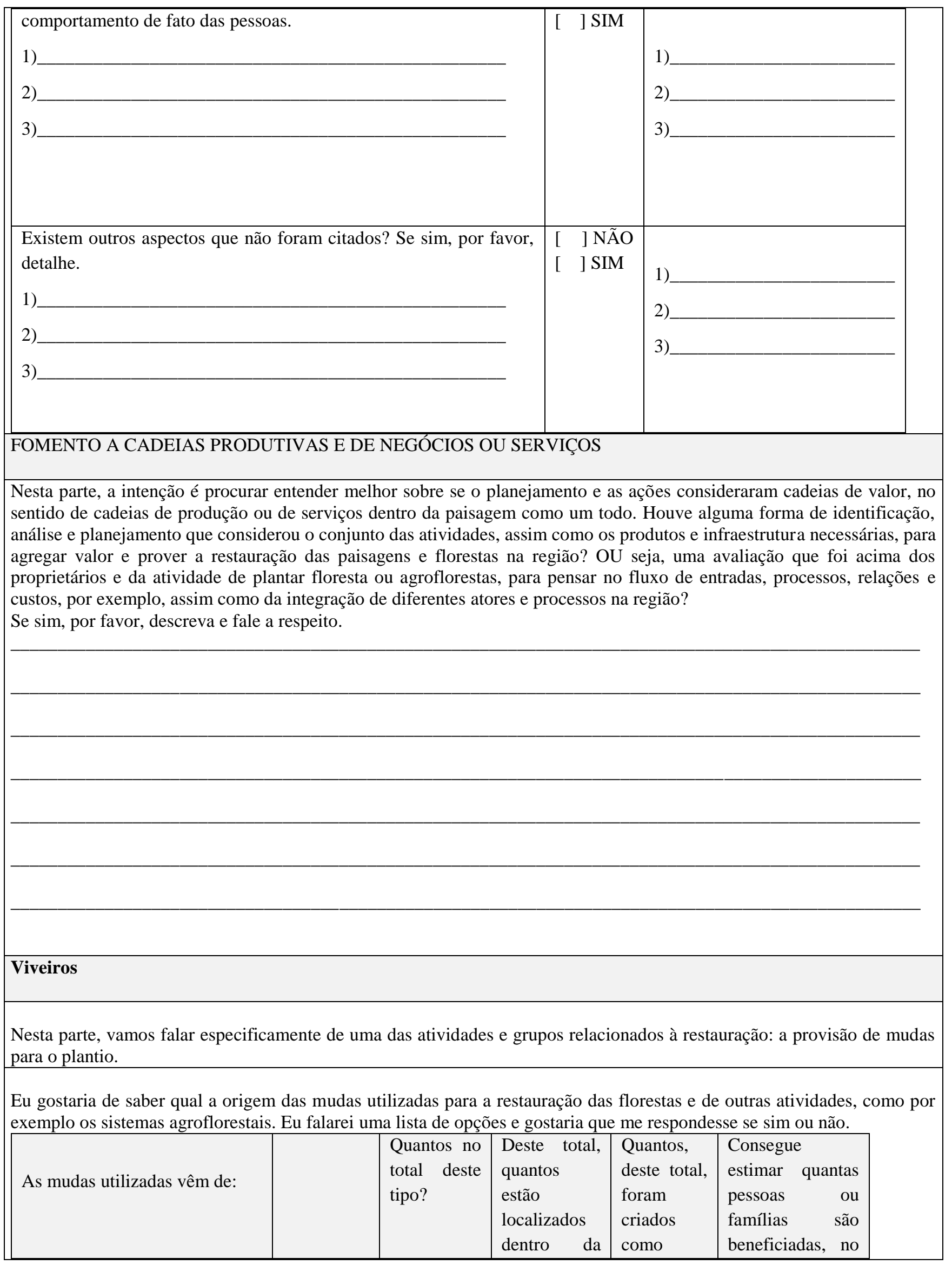




\begin{tabular}{|c|c|c|c|c|c|}
\hline & & & $\begin{array}{l}\text { paisagem de } \\
\text { intervenção? }\end{array}$ & $\begin{array}{l}\text { consequên } \\
\text { cia do } \\
\text { projeto? }\end{array}$ & total? \\
\hline $\begin{array}{llr}\begin{array}{l}\text { Viveiros } \\
\text { organização, }\end{array} & \begin{array}{r}\text { da } \\
\text { ou } \\
\text { (neste caso, }\end{array} & \begin{array}{r}\text { própria } \\
\text { seja, }\end{array} \\
d a O N G) & & \end{array}$ & $\begin{array}{l}\mid \text { | Não } \\
\mid \text { I_ Sim }\end{array}$ & | & | & | & $\begin{array}{ll} & \\
& \\
& \\
\begin{array}{l}\text { indicar } \\
\text { pessoas, familias, } \\
\text { outros) }\end{array}\end{array}$ \\
\hline Viveiros externos familiares & $\begin{array}{l}\ldots \text { Não } \\
\mid \ldots \text { Sim }\end{array}$ & | & 1 & L & $\begin{array}{ll}1 & \\
& \\
& \\
\begin{array}{l}\text { (indicar } \\
\text { pessoas, familias, } \\
\text { outros) }\end{array}\end{array}$ \\
\hline Viveiros externos comerciais & $\begin{array}{l}\text { _ Não } \\
\mid \text { | Sim }\end{array}$ & | & | & L & $\begin{array}{ll}1 & \\
& \\
& \\
\begin{array}{l}\text { indicar } \\
\text { pessoas, familias, } \\
\text { outros) }\end{array}\end{array}$ \\
\hline Outros tipos? Qual? & & & & & \\
\hline
\end{tabular}

Como são selecionados atualmente os viveiros que fornecem as mudas para cada plantio? Por favor, descreva.

Quem define a tabela de preços das mudas a serem utilizadas na restauração atualmente: (escolha uma das alternativas)

[ ] sempre vocês, ou seja, a organização que realiza a restauração

[ ] sempre o vendedor das mudas

[ ] depende do proprietário, ou seja, variou segundo o proprietário.

[ ] depende da ocasião, ou seja, variou no tempo.

[ ] Outras (descrever):

Das alternativas que eu vou falar, qual reflete melhor a forma como é definida a tabela de preços das mudas fornecidas por 
estes viveiros? (escolha as alternativas pertinentes)

[ ] o preço é calculado pelo produtor de mudas, segundo o custo que ele tem na produção

[ ] o preço é calculado pelo produtor de mudas, segundo um valor que ele considera justo receber, ou seja, quanto gostaria de ganhar

[ ] o preço é estabelecido pelo comprador, segundo quanto este pode ou quer pagar.

[ ] o preço é fruto de uma negociação entre produtor e comprador.

[ ] ] Outras formas (descrever):

\section{Empresas ou responsáveis pelo plantio}

Nesta parte, vamos falar especificamente das pessoas ou empresas que realizaram efetivamente a restauração das florestas e, portanto, o plantio.

Em relação as pessoas ou organizações que realizaram os plantios de restauração (ou seja, de floresta) desde o início da implementação do projeto, por favor, indique quais das alternativas que eu falarei se aplicam ou não:

\begin{tabular}{|c|c|c|c|c|}
\hline $\begin{array}{l}\text { Os plantios foram } \\
\text { realizados por: }\end{array}$ & & $\begin{array}{l}\text { Quantos indivíduos } \\
\text { / empresas } \\
\text { aproximadamente } \\
\text { no total? } \\
\text { E, do total, quantos } \\
\text { eram mulheres? }\end{array}$ & $\begin{array}{l}\text { Deste total, quantos } \\
\text { indivíduos/ } \\
\text { empresas estão } \\
\text { dentro da paisagem } \\
\text { de intervenção? } \\
\text { Caso não saiba o } \\
\text { número, indique a } \\
\text { proporção } \\
\text { aproximada }\end{array}$ & \\
\hline $\begin{array}{l}\text { Indivíduos fizeram o } \\
\text { plantio em suas próprias } \\
\text { propriedades? }\end{array}$ & $\begin{array}{l}\ldots \text { Não } \\
\ldots\end{array}$ & $\begin{array}{l}\text { Total: }\left.\right|_{\perp} \mid \\
\text { Mulheres? } \mid \text { __ } \mid \%\end{array}$ & $\begin{array}{l}\text { não se aplica } \\
(\text { todos })\end{array}$ & Não se aplica \\
\hline $\begin{array}{l}\text { Indivíduos da própria } \\
\text { organização fizeram o } \\
\text { plantio (neste caso, a } \\
O N G)\end{array}$ & $\begin{array}{l}\ldots \text { Não } \\
\mid \ldots \text { Sim }\end{array}$ & $\begin{array}{l}\text { Total: }\left|\_\right| \\
\text {Mulheres? }\left|\_\right| \%\end{array}$ & $\begin{array}{l}\text { não se aplica } \\
\text { (todos) }\end{array}$ & Não se aplica \\
\hline $\begin{array}{l}\text { Indivíduos contratados } \\
\text { fizeram o plantio em } \\
\text { outras propriedades }\end{array}$ & $\begin{array}{l}|\ldots| \text { Não } \\
\mid \ldots \text { Sim }\end{array}$ & $\begin{array}{l}\text { Total de pessoas: } \\
\text { Mulheres? |__ } \mid \%\end{array}$ & $\begin{array}{l}\mid \begin{array}{l}\mid \\
\text { indivíduos }\end{array} \\
\begin{array}{l}\text { indivíduos } \\
\text { paisagem }\end{array} \\
\text { na de }\end{array}$ & $\begin{array}{l}\text { Quantos deste total eram: } \\
\text { a) pessoas conhecidas ou } \\
\text { indicadas por conhecidos: } \\
\text { b) pessoas selecionadas por } \\
\text { alguma chamada ou edital: }\end{array}$ \\
\hline $\begin{array}{l}\text { Empresas registradas } \\
\text { fizeram o plantio }\end{array}$ & $\begin{array}{l}\ldots \text { Não } \\
\mid \ldots \text { Sim }\end{array}$ & $\begin{array}{l}\text { Total } \quad \text { de } \\
\text { empresas: }\left.\right|_{\ldots} \mid\end{array}$ & $\begin{array}{lr}\text { Quantas } & \text { dessas } \\
\text { empresas } & \text { estão } \\
\text { estabelecidas dentro }\end{array}$ & $\begin{array}{l}\text { Como essas empresas foram } \\
\text { selecionadas (marcar todas } \\
\text { que se aplicam): }\end{array}$ \\
\hline
\end{tabular}




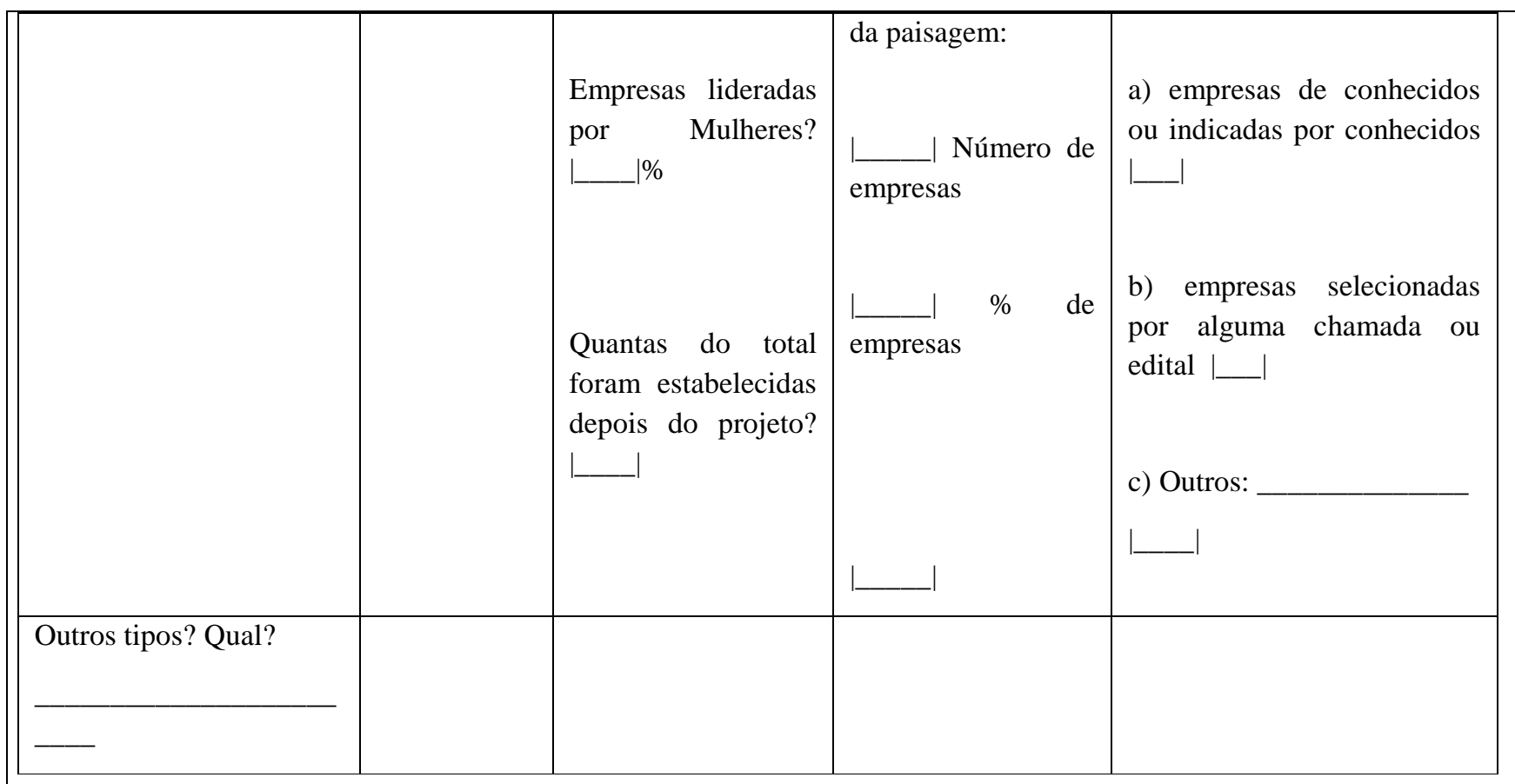

Como são selecionados atualmente os indivíduos ou as empresas que fazem o plantio? Por favor, descreva.

Quem define a tabela de preços a serem pagos pelo plantio .

[ ] sempre vocês, ou seja, a organização que realiza a restauração

[ ] sempre o indivíduo ou a empresa que realiza o plantio

[ ] depende do indivíduo ou da empresa. Como? (Descrever):

[ ] depende da ocasião, ou seja, variou no tempo.

[ ] Outras (descrever):

Das alternativas que eu vou falar, qual reflete melhor a forma como é definida a tabela de preços pagos pelo plantio? (escolha as alternativas pertinentes)

[ ] o preço é calculado pelo indivíduo ou empresa que fazem o plantio, segundo o custo que eles têm.

[ ] o preço é calculado pelo indivíduo ou empresa, segundo um valor que eles consideram justo receber, ou seja, quanto gostariam de ganhar

[ ] o preço é estabelecido pelo comprador, segundo quanto este pode ou quer pagar.

[ ] o preço é fruto de uma negociação entre produtor e comprador.

[ ] Outras formas (descrever):

\section{PARTE C - LEIS E NORMAS APLICÁVEIS}

Agora gostaríamos de conversar sobre as leis e normas que poderiam ser aplicadas ao contexto do projeto de restauração. Quanto às leis e normas aplicáveis aos projetos de FLR, existem leis ambientais que vocês identificaram como importantes

de serem seguidas por vocês e pelos participantes do projeto no momento da implementação do projeto?

[ ] NÃO [ ] SIM. 


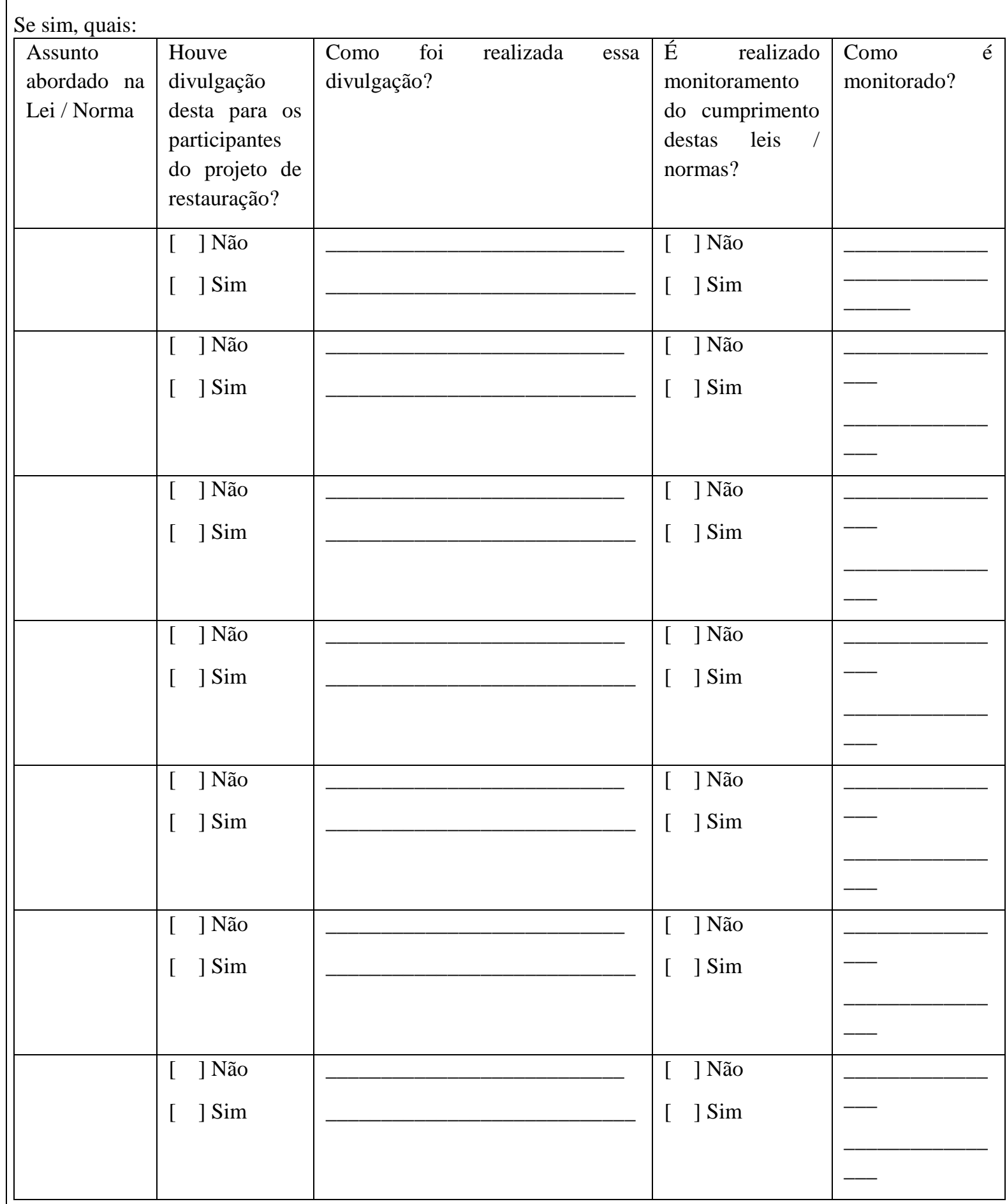

Quanto às leis e normas aplicáveis aos projetos de FLR, existem leis, normas ou procedimentos relacionados às pessoas que foram considerados. Por exemplo, em questões de direitos fundamentais, trabalho, garantia da segurança nos procedimentos de restauração, ou da saúde dos envolvidos que foram identificadas como importantes de serem seguidas por vocês e divulgadas aos participantes do projeto? [ ] NÃO [ ] SIM.

Se sim, quais foram especificamente essas normas ou leis :

\begin{tabular}{|l|l|l|lr|l|}
\hline $\begin{array}{l}\text { Assunto da Lei / } \\
\text { Norma/Direito }\end{array}$ & $\begin{array}{l}\text { Houve } \\
\text { divulgação } \\
\text { desta para os }\end{array}$ & $\begin{array}{l}\text { Se sim, como foi } \\
\text { realizada a divulgação? }\end{array}$ & $\begin{array}{l}\text { É realizado } \\
\text { monitoramento do } \\
\text { cumprimento destas }\end{array}$ & Como é monitorado? \\
\hline
\end{tabular}




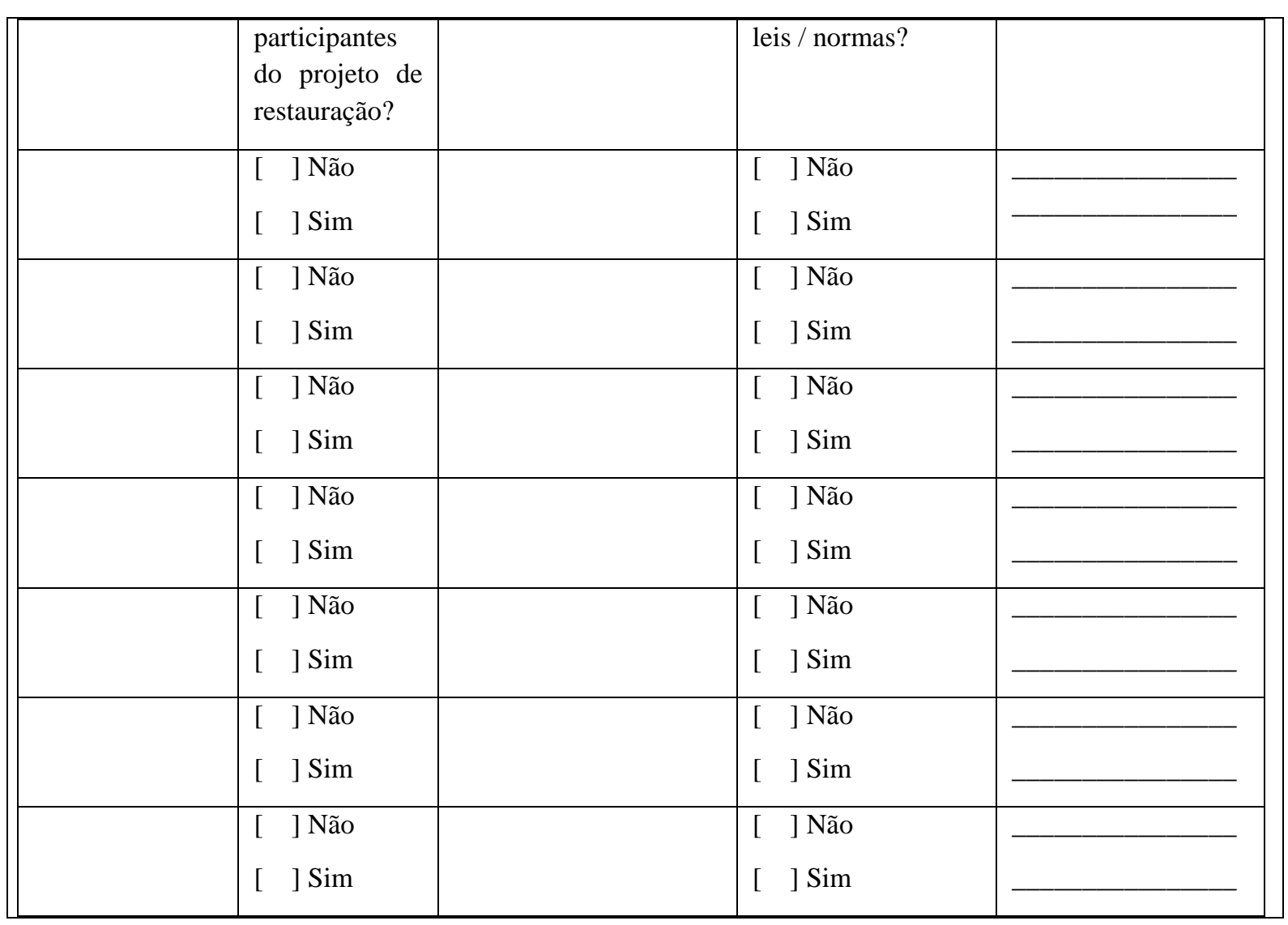




\section{PARTE D - PROCESSO PARTICIPATIVO}

Nesta quarta parte gostaríamos de conversar sobre como foi a inclusão e participação dos demais atores envolvidos no projeto de restauração.

\section{Perguntas}

Foram realizadas reuniões coletivas e outros tipos de eventos envolvendo a comunidade local durante as seguintes fases:

planejamento:ou [ ] N ÃO [ ] SIM

implementação [ ] NÃO [ ] SIM

monitoramento do projeto, ou [ ] NÃO [ ] SIM

Se sim, aproximadamente, quantas reuniões e eventos foram realizados:

Desde o início do projeto? |__ E no último ano, ou seja, de agosto de 2018 até hoje:

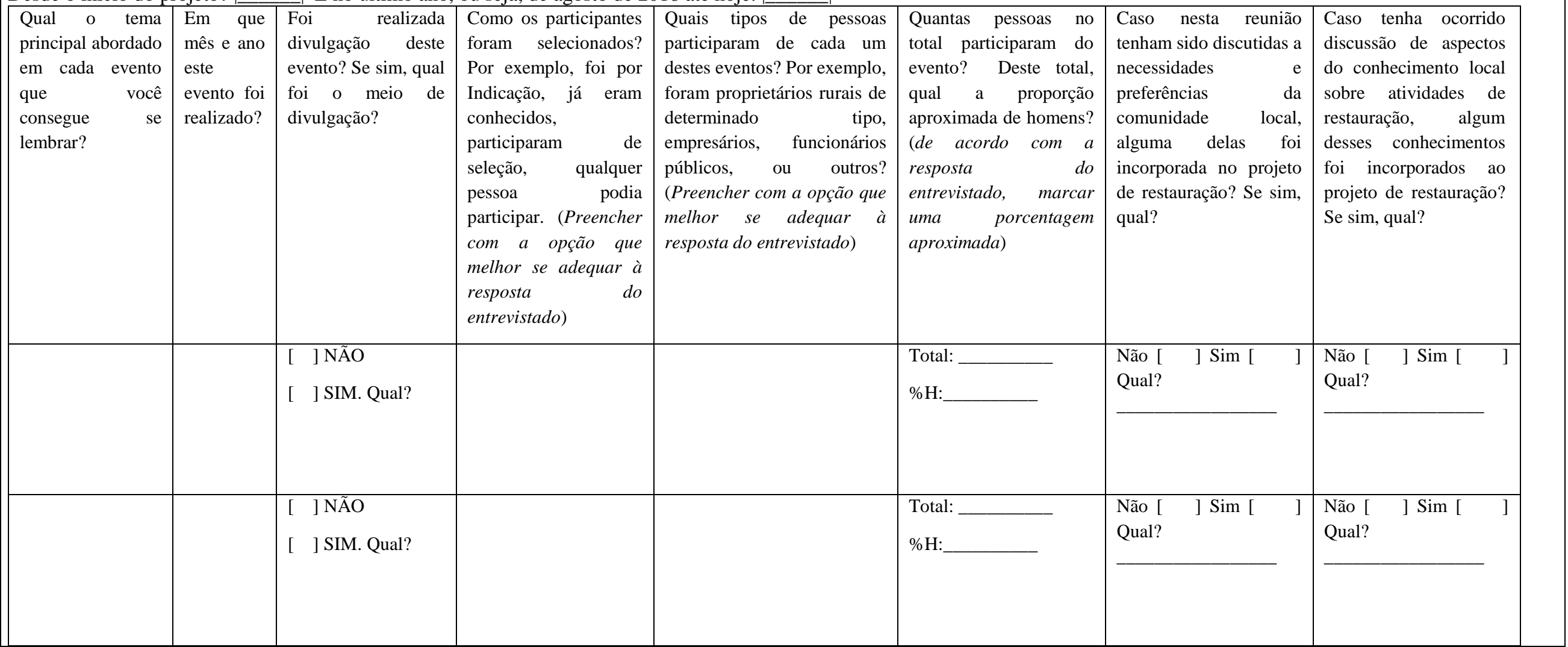




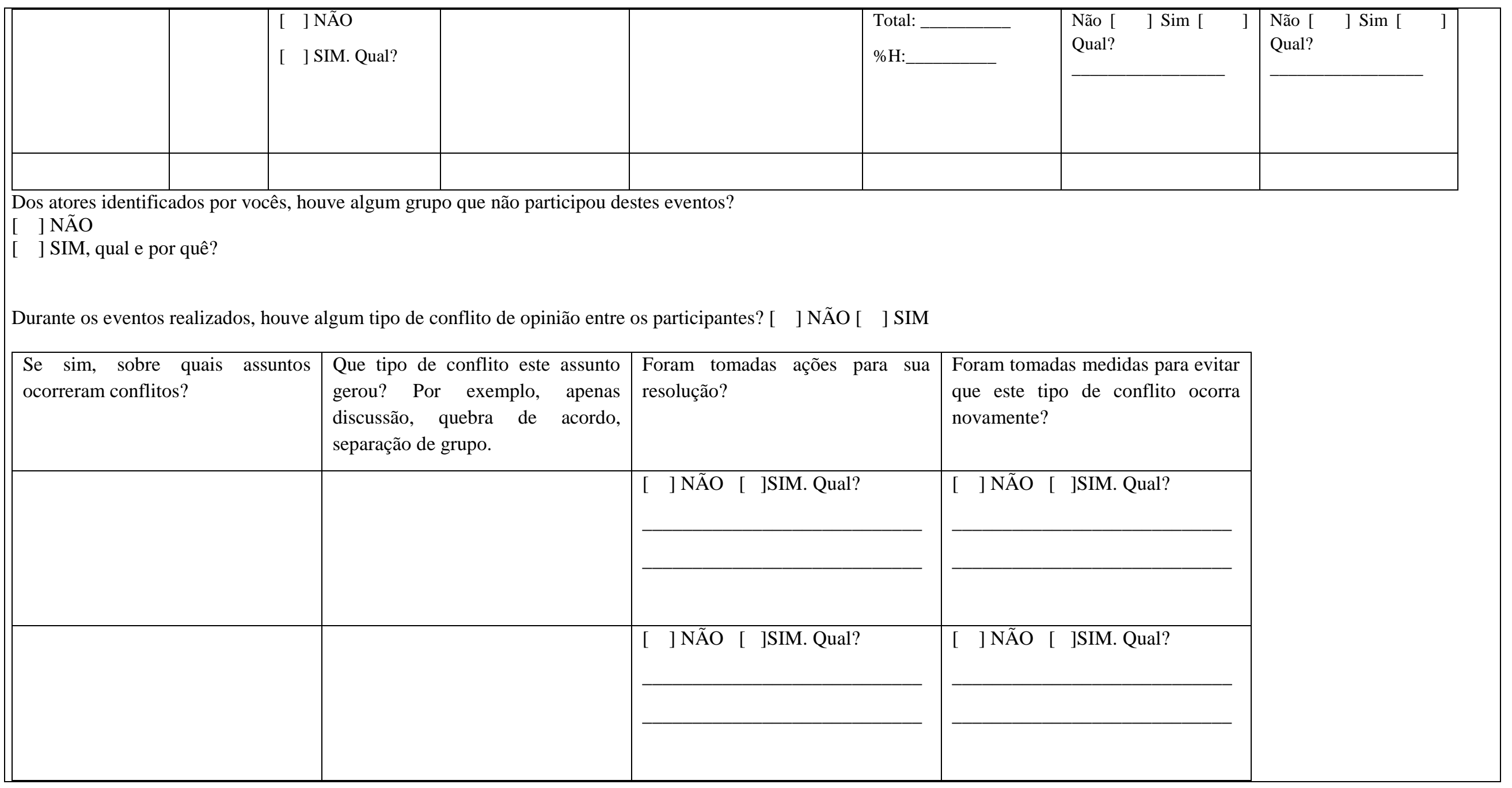


Foram realizadas parcerias com outras organizações como, por exemplo, aquelas de pesquisa e ensino, empresas, governo e ONGs, para auxiliar no planejamento e na implementação do projeto? [ ] NÃO [ ] SIM

Se sim, qual é cada uma das instituições parcerias e qual é a natureza destas, por ex., ONG, governo, associação de proprietários, dentre outros.

Instituição:

instituições para o projeto de restauração?

1)

Natureza:

2)

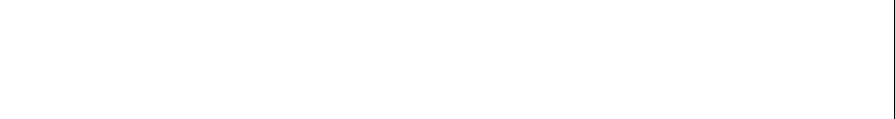

Instituição:

1)

Natureza:

2)

Instituição:

1)

Natureza:

2)

Instituição:

1) 


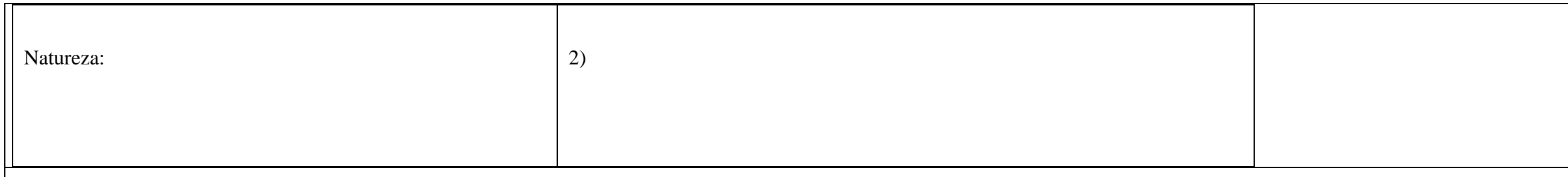

Desde a fase de planejamento do projeto de restauração até hoje, foi disponibilizado algum canal de comunicação, como telefone de contato, site e email, para que partes interessadas em participar ou obter informações do projeto de restauração entrassem em contato para tirar dúvidas e ou para fazerem sugestões? [ ] NÃO [ ] SIM

Se sim, quais canais foram disponibilizados?

1)

2)

3)

4)

Desde a fase de planejamento do projeto de restauração até o dia de hoje, foi feito algum tipo de divulgação das ações e dos eventos do projeto?

[ ] NÃO [ ] SIM

Se sim, qual(is) meio(s) de divulgação foi(ram) usado(s)? Quais tipos de pessoas ou de público cada um desses meios de divulgação pretendia atingir?

\begin{tabular}{|l|l|}
\hline Meio de Divulgação & Públicos-Alvo
\end{tabular}

\begin{tabular}{|l|l|}
\hline Meio de Divulgação & Públicos-Alvo \\
\hline & \\
\hline & \\
\hline & \\
\hline & \\
\hline
\end{tabular}




\begin{tabular}{|c|c|c|c|c|c|}
\hline \multicolumn{6}{|c|}{$\begin{array}{l}\text { Foram realizados cursos de capacitação ou programas de treinamento destinados à comunidade local do } \\
\text { projeto de restauração florestal? [ ] NÂO [ ] SIM } \\
\text { Se sim, quantos cursos de capacitação ou programas de treinamento foram realizados? [ }\end{array}$} \\
\hline \multirow[t]{4}{*}{\begin{tabular}{|l|} 
Qual o tema abordado em \\
cada curso? E quantos \\
cursos foram oferecidos \\
sobre cada tema? (caso \\
tenha sido oferecido mais \\
de uma vez, repetir o tema \\
do curso na quantidade de \\
linhas equivalente para \\
preenchimento adequado \\
das demais informações)
\end{tabular}} & $\begin{array}{l}\text { Quantas pessoas no total participaram } \\
\text { de cada um desses cursos ou } \\
\text { treinamento? Deste, qual proporção } \\
\text { era de homens? (de acordo com a } \\
\text { resposta do entrevistado, marcar uma } \\
\text { porcentagem aproximada) }\end{array}$ & $\begin{array}{l}\text { Quais tipos de pessoas participaram de } \\
\text { cada um desses cursos? } \\
\text { (proprietários de assentamento rural } \\
\text { (RUR), morador da área urbana (URB), } \\
\text { pessoas que fazem parte da gestão do } \\
\text { projeto (GES), dentre outros (OUT)). } \\
\text { (Preencher com sigla da opção que } \\
\text { melhor se adequar à resposta do } \\
\text { entrevistado) }\end{array}$ & $\begin{array}{l}\text { Como estas pessoas foram } \\
\text { selecionadas? Por exemplo, foi } \\
\text { por Indicação, já eram } \\
\text { conhecidos, participaram de } \\
\text { seleção, qualquer pessoa podia } \\
\text { participar. (Preencher com a } \\
\text { opção que melhor se adequar à } \\
\text { resposta do entrevistado) }\end{array}$ & \begin{tabular}{|l} 
Foi realizada \\
divulgação \\
deste curso?
\end{tabular} & $\begin{array}{l}\text { Se sim, qual foi o principal } \\
\text { meio de divulgação utilizado e } \\
\text { qual era o público principal que } \\
\text { se esperava atingir? }\end{array}$ \\
\hline & $\begin{array}{l}\text { Total: } \\
\% \mathrm{H}:\end{array}$ & & & {$\left[\begin{array}{l}{[} \\
{[}\end{array}\right] \mathrm{NÃO}$} & $\begin{array}{l}\text { Meio: } \\
\text { Público: }\end{array}$ \\
\hline & $\begin{array}{l}\text { Total: } \\
\% \mathrm{H}: \\
\end{array}$ & & & {$\left[\begin{array}{l}{[} \\
{[}\end{array}\right] \mathrm{NÃO}$} & $\begin{array}{l}\text { Meio: } \\
\text { Público: }\end{array}$ \\
\hline & $\begin{array}{l}\text { Total: } \\
\% \mathrm{H}: \\
\end{array}$ & & & 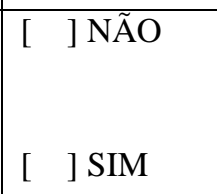 & $\begin{array}{l}\text { Meio: } \\
\text { Público: }\end{array}$ \\
\hline
\end{tabular}




\begin{tabular}{|c|c|c|c|c|c|}
\hline \multicolumn{6}{|c|}{ PARTE E - MONITORAMENTO } \\
\hline \multicolumn{6}{|l|}{ Perguntas } \\
\hline \multicolumn{6}{|c|}{$\begin{array}{l}\text { São realizadas atividades de monitoramento, ou seja, de verificação dos resultados socioeconômicos ou outros aspectos humanos das atividades relacionadas ao projeto de restauração? } \\
\text { ] NÃO [ ] SIM }\end{array}$} \\
\hline \multirow[t]{4}{*}{\begin{tabular}{|lr} 
Por favor, liste \\
cada um dos \\
aspectos r ou \\
indicadores \\
são \\
monitorados.
\end{tabular}} & $\begin{array}{l}\text { Com qual frequência este indicador é } \\
\text { monitorado? Por exemplo, semanalmente } \\
\text { (SEMA), mensalmente (MEN), semestralmente } \\
\text { (SEMES), dentre outros. (Preencher com sigla } \\
\text { da opção que melhor se adequar à resposta do } \\
\text { entrevistado) }\end{array}$ & $\begin{array}{l}\text { Qual método é usado para realizar o } \\
\text { monitoramento deste indicador? Por exemplo, } \\
\text { aplicação de questionário (QUEST), coleta de } \\
\text { dados em campo (CAMP), observação } \\
\text { (OBS), entrevista (ENTR), dentre outros. } \\
\text { (Preencher com sigla da opção que melhor se } \\
\text { adequar à resposta do entrevistado) }\end{array}$ & $\begin{array}{l}\text { Quem realiza este monitoramer } \\
\text { exemplo, se são moradores lo } \\
\text { moradores locais contratado } \\
\text { contratadas de fora (FORA) pe } \\
\text { gestão do projeto (GEST), } \\
\text { (PESQ), dentre outros (OUT), } \\
\text { de homens. (Preencher com sig } \\
\text { se adequar à resposta do entre }\end{array}$ & $\begin{array}{l}\text { Favor informar, por } \\
\text { voluntários (LOC), } \\
\text { CONTR), pessoas } \\
\text { que fazem parte da } \\
\text { uições de pesquisa } \\
\text { licando a proporção } \\
\text { a opção que melhor } \\
\text { do) }\end{array}$ & $\begin{array}{l}\text { Os resultados } \\
\text { identificados através } \\
\text { do monitoramento são } \\
\text { divulgados? }\end{array}$ \\
\hline & & & 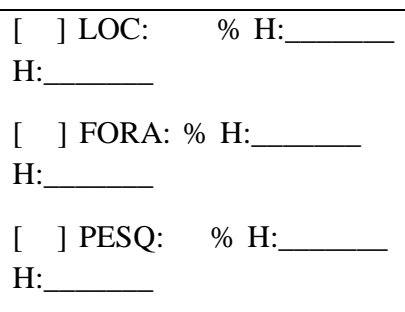 & $\begin{array}{l}\text { [ ] CONTR: \% } \\
\text { [ ] GEST: \% } \\
\text { [ ] OUT: } \%\end{array}$ & [ ] NÃO [ ] SIM \\
\hline & & & $\begin{array}{l}\text { [ ] LOC: \% H:_- } \\
\mathrm{H}:[\text { ] FORA: \% H:- } \\
\mathrm{H:} \\
\text { [ ] PESQ: \% H:- } \\
\mathrm{H:}\end{array}$ & $\begin{array}{l}\text { [ ] CONTR: \% } \\
\text { [ ] GEST: \% } \\
\text { [ ] OUT: } \%\end{array}$ & [ ] NÃO [ ] SIM \\
\hline & & & 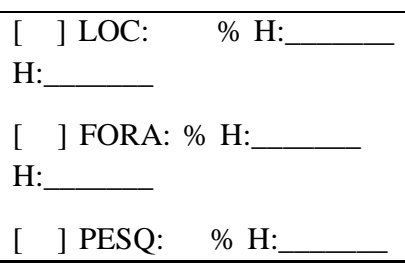 & $\begin{array}{l}\text { [ ] CONTR: \% } \\
\text { [ ] GEST: } \% \\
\text { [ ] OUT: } \%\end{array}$ & [ ] NÃO [ ] SIM \\
\hline
\end{tabular}




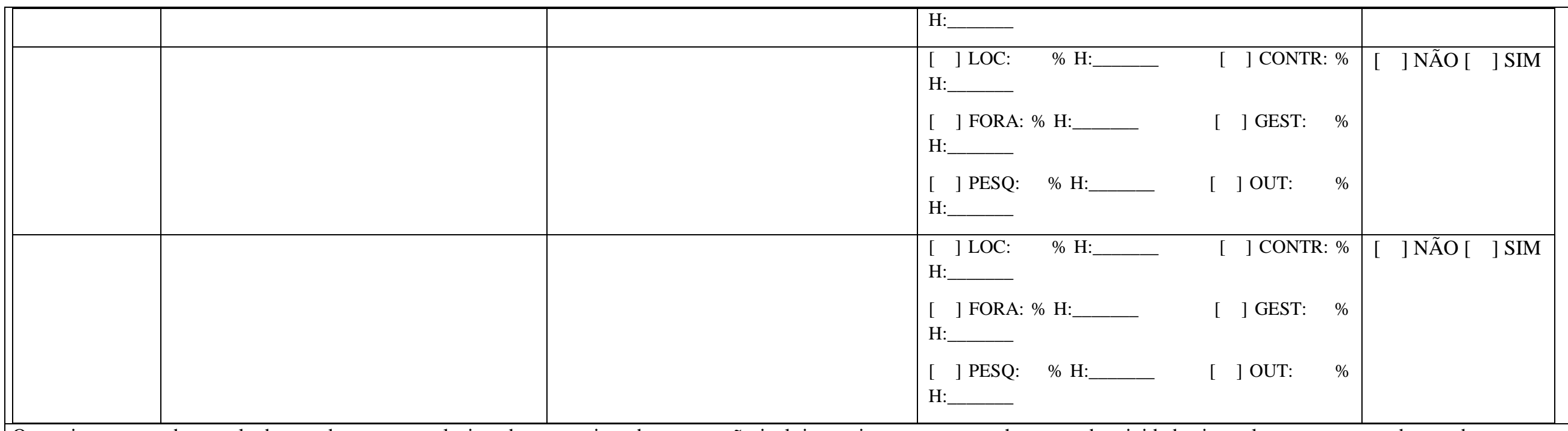

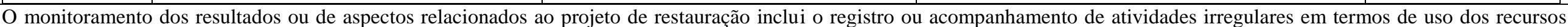
naturais como, por exemplo, práticas ilegais de extração ou de consumo de espécies nativas, ou outras formas? [ ] NÃO [ ] SIM

Por favor, detalhe:

Se sim, é tomada alguma medida para evitar que este tipo de acontecimento se repita?

[ ] NÃO

[ ] SIM. Qual medida?

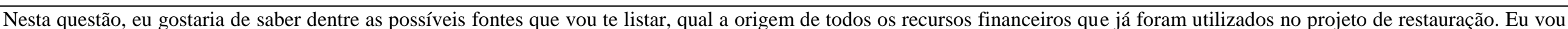

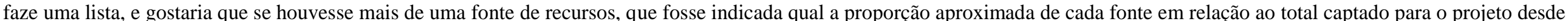
quando foi iniciado até hoje.

\begin{tabular}{|l|l|l|}
\hline Fonte de Recurso & Não ou Sim? & Proporção \\
\hline De órgão públicos do país & [ ] NÃO [ ] SIM & $\%$ \\
\hline
\end{tabular}




\begin{tabular}{|c|c|c|}
\hline De órgãos internacionais ou multilaterais & [ ] NÃO [ ] SIM & $\%$ \\
\hline De organizações não governamentais nacionais & [ ] NÃO [ ] SIM & $\%$ \\
\hline De fundos para a conservação & [ ] NÃO [ ] SIM & $\%$ \\
\hline De Empresas Privadas & [ ] NÃO [ ] SIM & $\%$ \\
\hline Por financiamento colaborativo - crowdfunding & [ ] NÃO [ ] SIM & $\%$ \\
\hline Outros: & [ ] NÃO [ ] SIM & $\%$ \\
\hline Outros: & [ ] NÃO [ ] SIM & $\%$ \\
\hline Outros: & [ ] NÃO [ ] SIM & $\%$ \\
\hline Outros: & [ ] NÃO [ ] SIM & $\%$ \\
\hline
\end{tabular}

Durante o último ano, ou seja, desde o dia

(falar dia e mês equivalente ao do ano passado) do ano passado até hoje, com quais atividades que eu vou te falar estes recursos financeiros foram utilizados? Favor indicar a proporção de recurso financeiro destinada a cada atividade.

\begin{tabular}{|l|l|l|l|}
\hline Atividade & $\begin{array}{l}\text { Utilização de Recurso } \\
\text { Financeiro? }\end{array}$ & Proporção \\
\hline Aquisição de Mudas & [ ] NÃO [ ] SIM & $\%$ \\
\hline Aquisição de Materiais necessários ao plantio & [ ] NÃO [ ] SIM & $\%$ \\
\hline Contratação de Mão-de-Obra para o plantio & [ ] NÃO [ ] SIM & $\%$ \\
\hline Realização de Cursos ou Treinamento & [ ] NÃO [ ] SIM & $\%$ \\
\hline Realização de Eventos e Reuniões & [ ] NÃO [ ] SIM & $\%$ \\
\hline Divulgação & [ ] NÃO [ ] SIM & $\%$ \\
\hline
\end{tabular}




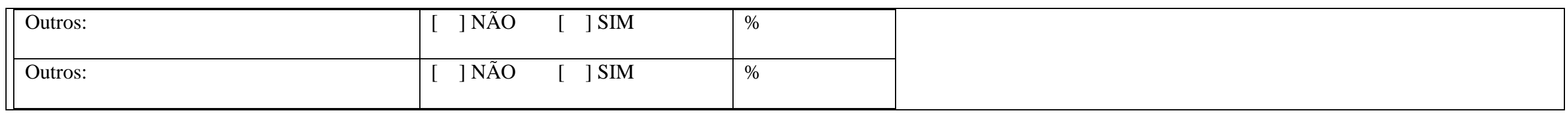

Desde o início de sua implantação até hoje, as atividades realizadas no projeto de restauração proporcionaram a geração de algum recurso financeiro para seus participantes? [ ] NÃo [ ] SIM

Se sim, os gestores do projeto haviam estimado o montante financeiro que seria possível gerar para o conjunto dos participantes na paisagem antes do início do projeto? [ ] NÃO [ ] SIM

Caso essa estimativa tenha sido feita, você diria que os resultados financeiros observados desde o início de sua implantação até hoje:
[ ] estão de acordo com o estimado?
[ ] estão acima do estimado? Quanto porcento acima? [ ]\%
[ ] não sei.

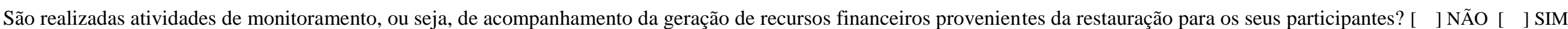

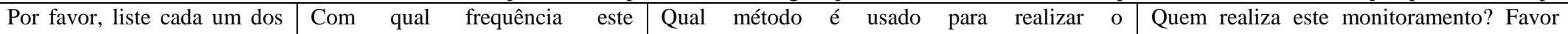

$\begin{aligned} & \text { aspectos ou indicadores que } \\ & \text { são monitorados. }\end{aligned}$
$\begin{aligned} & \text { indicador é monitorado? Por } \\ & \text { exemplo, semanalmente (SEMA), }\end{aligned}$ são monitorados.

$\begin{array}{ll}\text { mensalmente (MEN), } & \end{array}$

semestralmente (SEMES), dentre

outros. (Preencher com sigla da

opção que melhor se adequar à

resposta do entrevistado) monitoramento deste indicador? Por exemplo,

aplicação de questionário (QUEST), coleta de

dados em campo (CAMP), observação (OBS),

entrevista (ENTR), dentre outros. (Preencher

com sigla da opção que melhor se adequar à

resposta do entrevistado) informar, por exemplo, se são pessoas

contratadas (CONTR), moradores locais

(LOC), pessoas que fazem parte da gestão

do projeto (GEST), instituições de pesquisa

(PESQ), dentre outros (OUT), indicando a

proporção de homens. (Preencher com

sigla da opção que melhor se adequar à

resposta do entrevistado)

[ ] CONTR: \% H:

[ ] LOC: \% $\mathrm{H}$ :

[ ] GEST: \% H:

[ ] PESQ: \% H:

[ ] OUT: \% H:

[ ] CONTR: $\% \mathrm{H}$ :

[ ] LOC: \% H:
Os resultados

identificados através do

monitoramento

são

divulgados?

[ ] NÃO [ ] SIM

] NÃO [ ] SIM 


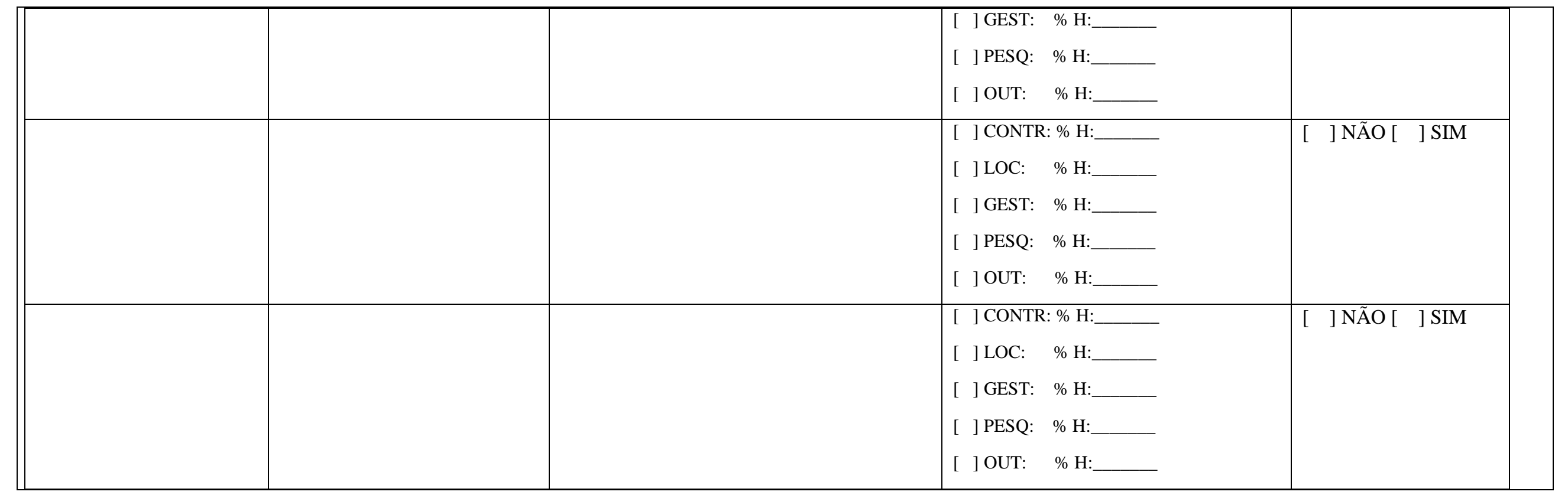


ANNEX III - Interview Protocol (Participants)

\section{INTRODUÇÃO PARA AS ENTREVISTAS (IMPRIMIR SOMENTE UMA VEZ)}

Olá,

Meu nome é e estou fazendo uma pesquisa para a Universidade de São Paulo. Queremos com essa pesquisa entender melhor algumas atividades feitas pelos moradores rurais no Pontal do Paranapanema como, por exemplo, plantar árvores e o projeto "Café com Floresta" realizado em algumas propriedades da região. Faremos entrevistas com várias famílias para saber como foram ou são feitas as atividades, quem participou e os resultados para vocês. Nossa intenção é entender quais atividades dão certo e o que pode ser melhorado em projetos futuros.

Peço a gentileza de saber se eu poderia conversar com a pessoa desta família ou propriedade que foi a principal responsável pela decisão de participar dessas atividades de plantio de árvores. Essa conversa deve levar em torno de minutos.

Gostaria de deixar claro que não existe resposta certa ou errada: o que vale para a gente é a opinião de vocês sobre esses assuntos que vamos conversar. Nós não vamos contar a ninguém o que as pessoas disseram e vamos manter o nome das pessoas que responderam em segredo.

Antes de começar gostaria de entregar este Termo de Consentimento. Este papel é um documento que explica os objetivos da entrevista que eu acabei de te explicar. Tem também o endereço da universidade e telefone, caso você tenha alguma dúvida ou queria entrar em contato com a gente. Este Termo tem duas cópias iguais que nós dois assinamos. Eu assino garantindo que não divulgarei seu nome a ninguém e você assina se aceitar participar da entrevista. A via que estou te entregando já está assinada por mim e ficará guardada com você, a outra via ficará arquivada comigo. 


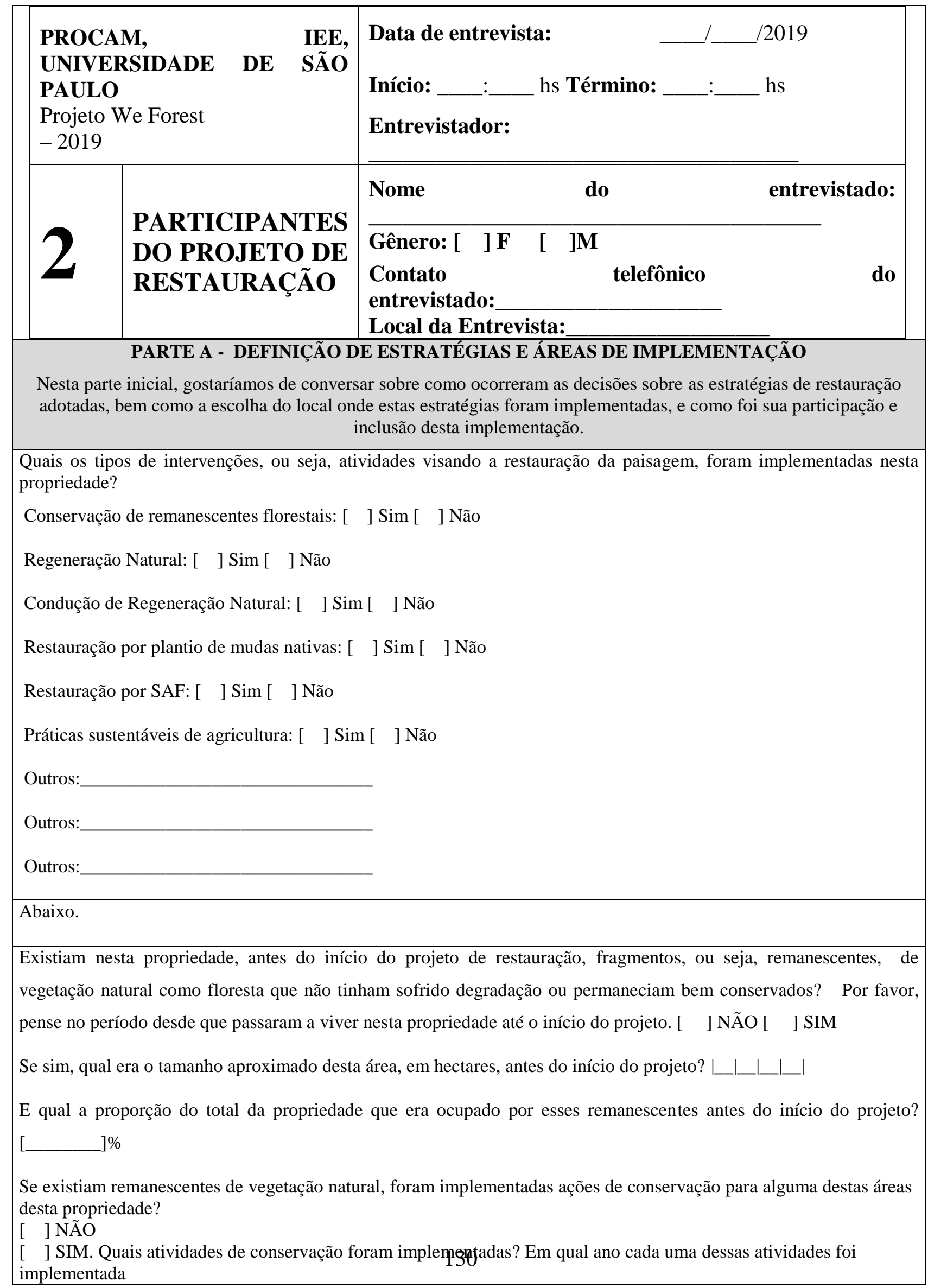




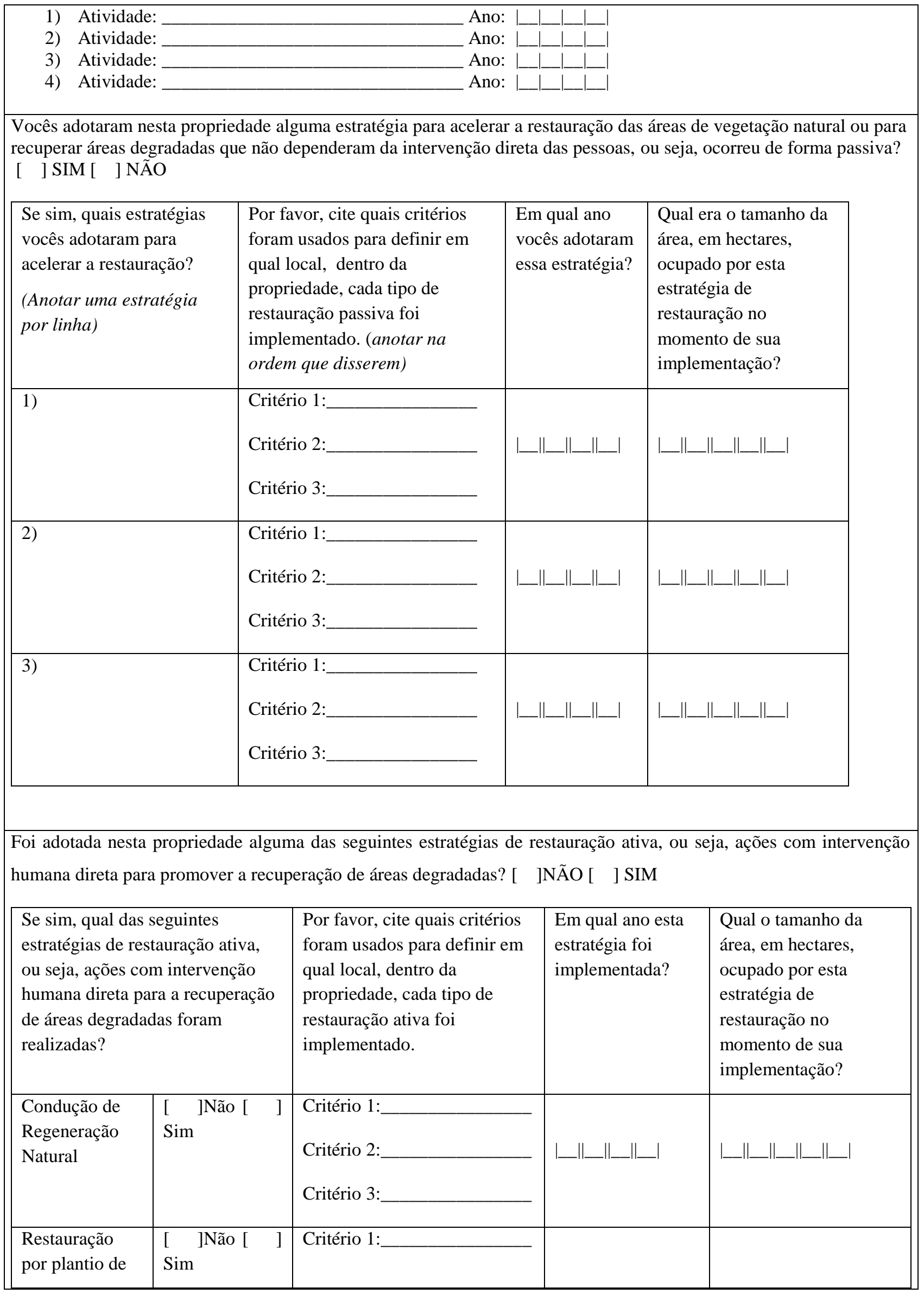




\begin{tabular}{|c|c|c|c|c|}
\hline mudas nativas & & $\begin{array}{l}\text { Critério } 2: \\
\text { Critério } 3:\end{array}$ & |_\|_\|__I_| & $\left|\_\left\|\_\right\| \_\left\|\_\right\| \_\right|$ \\
\hline $\begin{array}{l}\text { Restauração } \\
\text { por SAF }\end{array}$ & $\begin{array}{l}\text { [ ]Não [ ] } \\
\text { Sim }\end{array}$ & $\begin{array}{l}\text { Critério } 1: \\
\text { Critério } 2: \\
\text { Critério } 3:\end{array}$ & |_\|_\|_\|_ & |_\|__||_||_\|_| \\
\hline Outra: & $\begin{array}{l}\text { [ ]Não [ ] } \\
\text { Sim }\end{array}$ & $\begin{array}{l}\text { Critério } 1: \\
\text { Critério } 2: \\
\text { Critério } 3:\end{array}$ & |_\|__|_\|_| & 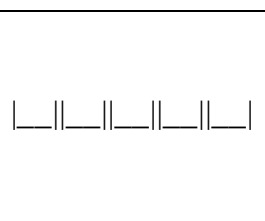 \\
\hline Outra: & $\begin{array}{l}\text { [ ]Não [ ] } \\
\text { Sim }\end{array}$ & $\begin{array}{l}\text { Critério 1: } \\
\text { Critério 2: } \\
\text { Critério 3: }\end{array}$ & 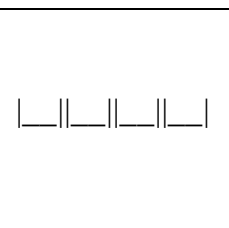 & |_L_\|_\|_\|_ \\
\hline Outra: & $\begin{array}{l}\text { [ ]Não [ ] } \\
\text { Sim }\end{array}$ & $\begin{array}{l}\text { Critério } 1: \\
\text { Critério } 2: \\
\text { Critério } 3:\end{array}$ & |_\|_\|__|_| & $\mid$ \\
\hline
\end{tabular}

Antes de vocês participarem do projeto, a área onde vocês fizeram de restauração eram usadas para alguma oura finalidade? Por favor, considerem o período desde que vocês vivem na propriedade até o início do projeto.

\section{[ ]NÃO [ ] SIM}

Se sim, com base das opções que vou te falar, como o(a) senhor(a) caracterizaria o tipo de uso que era feito nesta área?

[ ] área sem vegetação e sem uso específico naquele momento.

[ ] a área sem vegetação, mas com uso específico. Qual?

[ ] área com vegetação nativa, ou seja, vegetação típica deste local

[ ] área com vegetação exótica, ou seja, vegetação que não é típica deste local

[ ] plantio de monocultura. Qual?

Nos locais onde foram feitas ações de restauração, vocês realizaram alguma atividade de manutenção (como poda de galhos, conserto de cerca, colheita de café, dentre outras), nos últimos seis meses, ou seja, desde (falar dia e mês equivalente ao do ano passado) do ano passado até hoje? [ ] NÃO [ ] SIM

Se sim, quais atividades de manutenção foram feitas desde (falar dia e mês equivalente) do ano passado até hoje? (Anotar uma por linha)
Com qual frequência cada uma dessas atividades foi feita, considerando o período dos últimos seis meses, ou seja, desde __ (falar dia e mês equivalente) do ano passado até hoje? (semanalmente, mensalmente, a cada dois meses, a cada seis meses, outra
Quantas pessoas no total que vivem nesta propriedade participaram ao menos uma vez de alguma destas atividades na área de restauração desde _ (falar dia e mês equivalente ao do ano passado) do ano passado até hoje? 


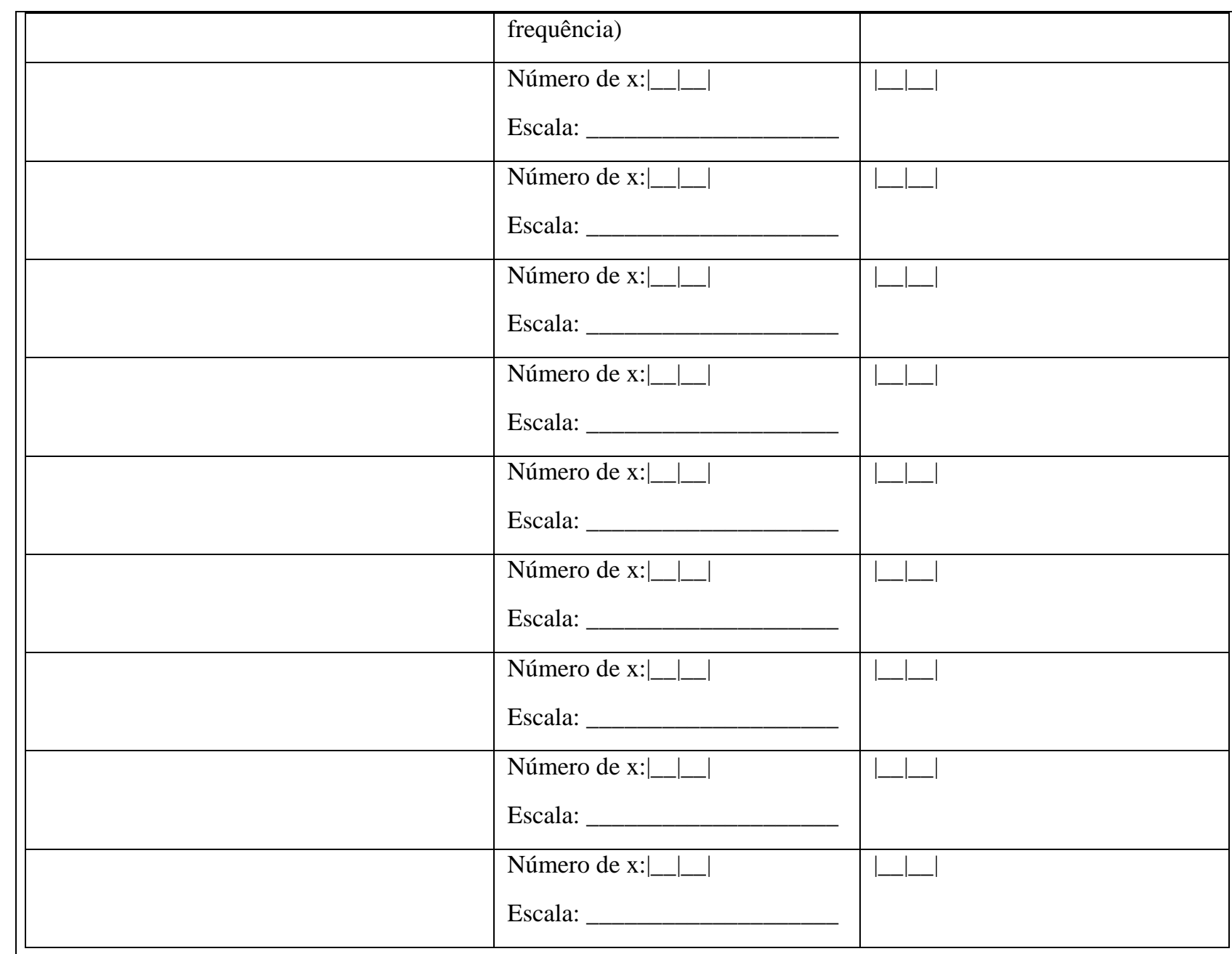

$\mathrm{O}$ (a) senhor(a) permite a entrada de animais, como cachorros ou gado, no local onde as ações de restauração foram realizadas?

\begin{tabular}{|l|l|}
\hline Gado & [ ] NÃO [ ] SIM \\
\hline Cachorro & [ ] NÃO [ ] SIM \\
\hline Gato & [ ] NÃO [ ] SIM \\
\hline Outros que permite (quais): & [ ] NÃO [ ] SIM \\
\hline Outros que permite (quais): & [ ] NÃO [ ] SIM \\
\hline Outros que permite (quais): & [ ] NÃO [ ] SIM \\
\hline
\end{tabular}

Existiam áreas de agricultura nesta propriedade, antes de vocês iniciarem as atividades de restauração? Por favor, considerem o período desde que vocês vivem na propriedade até o início do projeto.

[ ]NÃO [ ] SIM

Se sim, das opções que eu vou te falar, por favor, me diga qual explica melhor a finalidade dos plantios que existiam antes de vocês começarem as atividades de restauração:

[ ] Plantio para o consumo próprio das pessoas que vivem na propriedade.

[ ] Plantio para vender produtos agrícolas.

[ ] Ambos 
Houve mudanças nas práticas de agricultura que vocês usavam com objetivo de reduzir o impacto ambiental da atividade? Por favor, considere que sim apenas quando essas foram diretamente ou indiretamente resultado do projeto de restauração.

[ ] Não

Se sim, por favor descreva o tipo de ação:

[ ] Sim, mas só indiretamente

Tipo de Ação:

[ ] Sim, diretamente, ou seja, resultado específico de ações do projeto

Tipo de Ação:

Existiam áreas de pecuária na sua propriedade, antes de iniciarem as intervenções de restauração?

[ ]Não [ ] Sim

Se sim, houve transformação nas práticas de pecuária desde então que reduziram o impacto ambiental e que foram diretamente ou indiretamente resultado do projeto de restauração?

[ ] Não

Se sim, descrever o tipo de ação:

[ ] Sim, mas só indiretamente

Tipo de Ação:

[ ] Sim, diretamente, ou seja, resultado específico de ações do projeto

Tipo de Ação:

Quais os principais materiais e ferramentas que são necessários para desenvolver as atividades de plantio e manutenção das áreas de restauração que vocês têm? (colocar um item por linha)
Como vocês têm acesso a estes materiais e equipamentos?

Compra (COM),

Recebe doação (DOA),

Troca por outros materiais com pessoas do local (TRO), ou

Outra opção (OUT). 


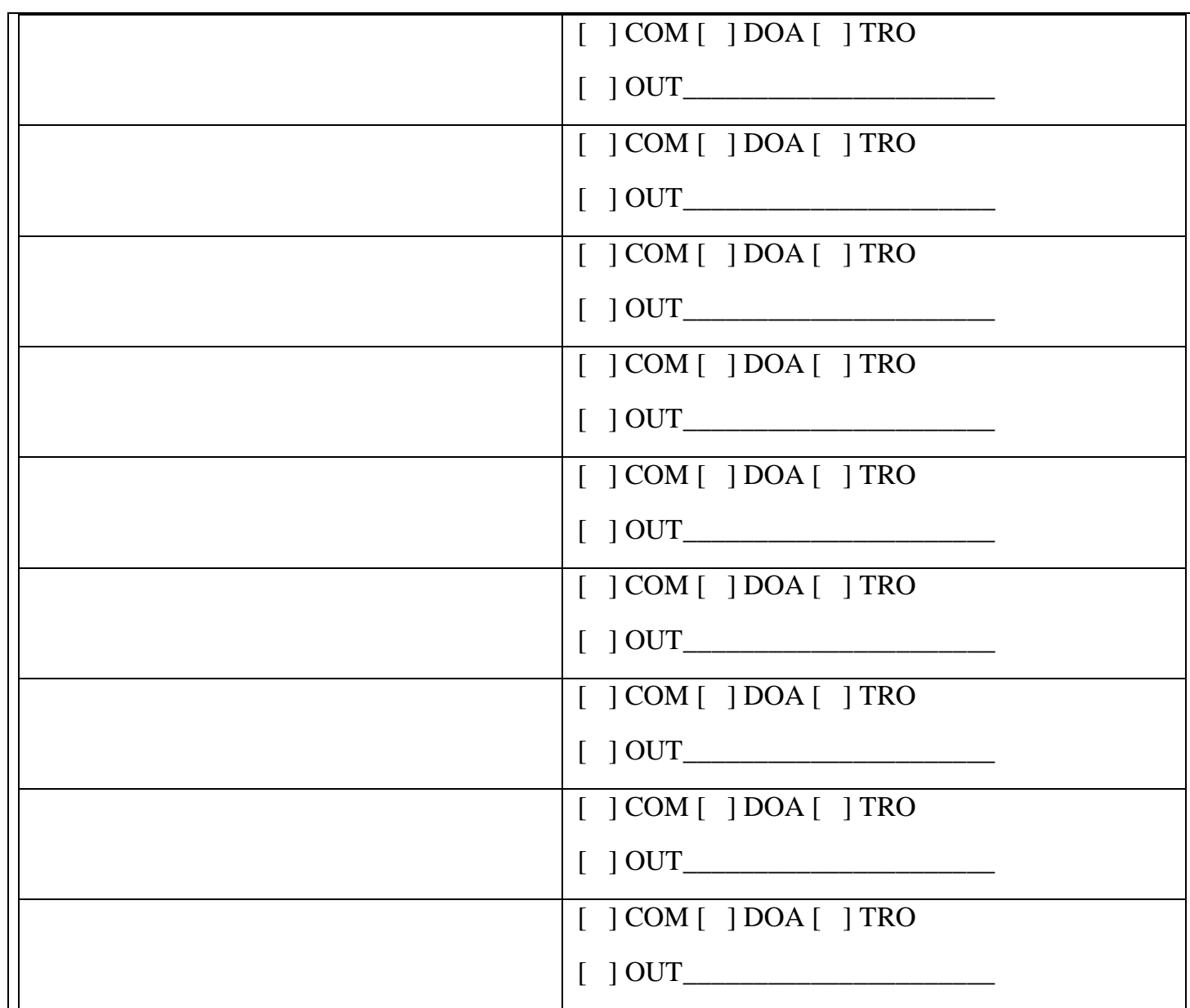

Em relação às pessoas ou organizações que realizaram os plantios de restauração (ou seja, de floresta) desde o início da implementação do projeto, por favor, indique quais das alternativas que eu falarei se aplicam ou não:

Os senhores fizeram plantio em sua própria propriedade? [ ] Não [ ] Sim

Contrataram pessoas para fazerem todo ou parte do plantio na propriedade:

[ ] Não

[ ] Sim, parte

[ ] Sim, parte

Se sim, esses indivíduos viviam dentro da paisagem selecionada:

[ ] Não

[ ] Sim, menos da metade viviam

[ ] sim, mais da metade vivia

[ ] sim, todos viviam na paisagem

Se sim, esses indivíduos eram (marcar todas que se aplicam):

[ ] pessoas conhecidas ou indicadas por conhecidos

[ ] pessoas enviadas pelo instituto que faz a gestão do projeto de restauração

[ ] Outros:

Empresas registradas fizeram o plantio na propriedade? [ ] NÃO [ ] SIM. Quantas empresas participaram?

Se sim, essas empresas foram formadas:

[ ] todas antes do início do projeto.

[ ] parte depois do início do projeto

[ ] Se parte, quantas?

[ ] Não sei

Se sim, essas empresas estão estabelecidas dentro da paisagem: 


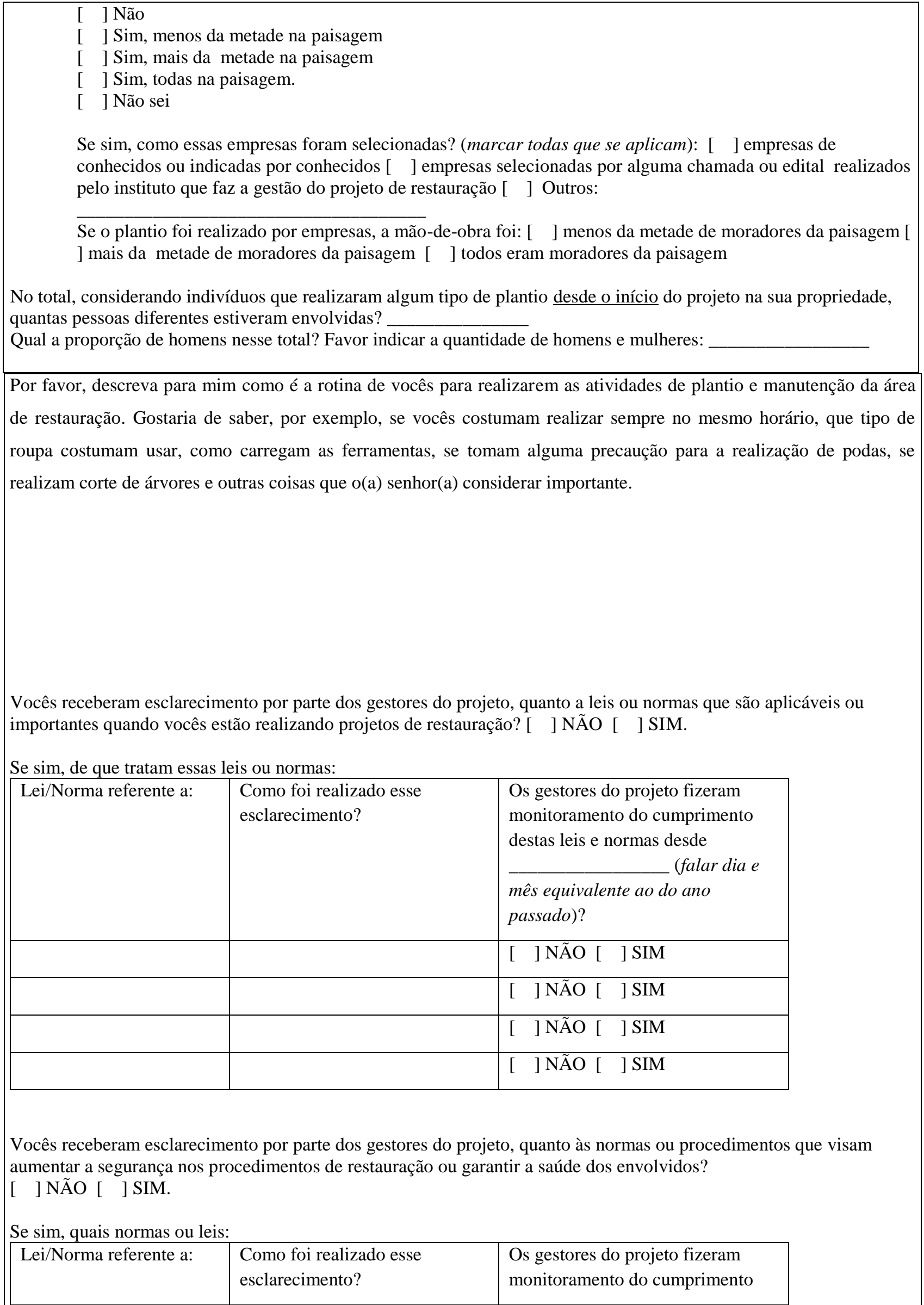




\begin{tabular}{||l|l|l|}
\hline & & $\begin{array}{l}\text { destas leis e normas desde } \\
\text { mês equivalente ao do ano } \\
\text { passado)? }\end{array}$ \\
\hline & & {$[$ ] NÃO [ ] SIM } \\
\hline & & {$[$ ] NÃO [ ] SIM } \\
\hline & [ ] ] Ñ̃O [ ] SIM \\
\hline & [ ] ] Ñ̃O [ ] SIM \\
\hline
\end{tabular}

\section{PARTE B - PROCESSO PARTICIPATIVO}

Agora, gostaria de conversar sobre como foram realizadas algumas atividades referentes às decisões e definições dentro do projeto de restauração, como o(a) senhor(a) foi envolvido, seu nível de inclusão e participação.

$\mathrm{O}(\mathrm{a})$ senhor(a) foi consultado pelos gestores do projeto de restauração para discutirem, planejar e opinar sobre as atividades e ações relacionadas ao projeto de restauração?

[ ] NÃO [ ]SIM

Se sim, quais assuntos foram abordados nessas conversas?

Em que mês e ano,

aproximadamente, essa consulta ocorreu?

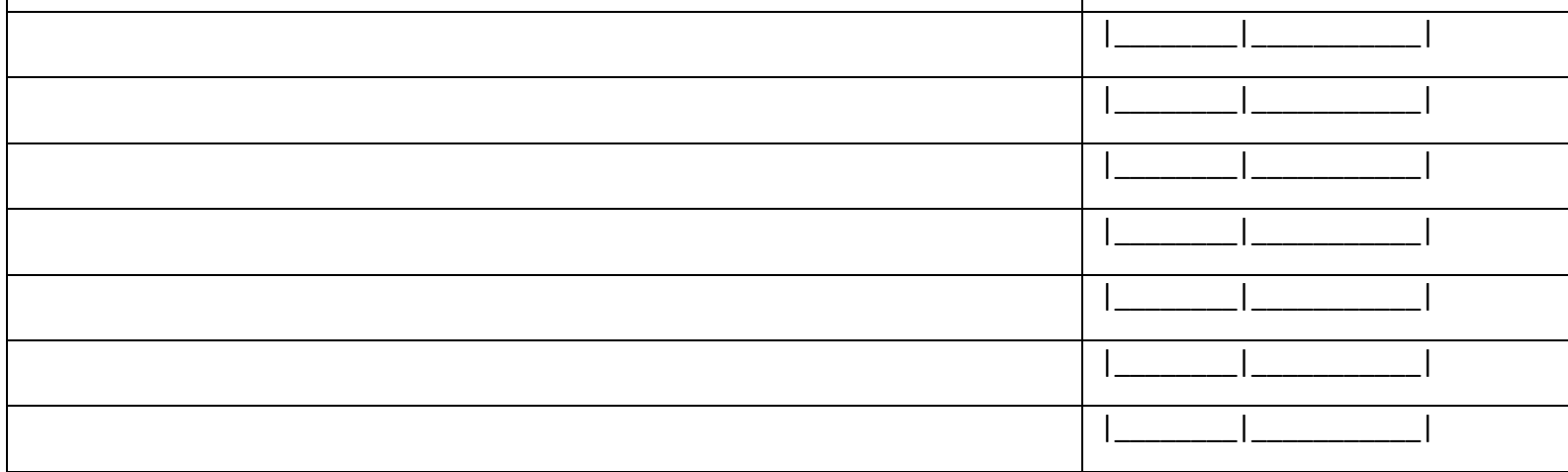

O(a) senhor(a) participou de reuniões ou outros eventos para discutir e planejar alguma ação ou atividade de restauração, ou seja do plantio de árvores nas propriedades?

[ ] NÃO [ ]SIM

Se sim, quantas reuniões e eventos o(a) senhor(a) participou

I__ |reuniões

(dizer data de hoje no ano passado) ?

Agora eu gostaria que o senhor(a) me falasse de cada um desses eventos que participou, começando pelo primeiro, ou seja, aquele mais antigo.

\begin{tabular}{|c|c|c|c|c|}
\hline $\begin{array}{l}\text { Qual foi o } \\
\text { principal } \\
\text { assunto que foi } \\
\text { tratado nesse } \\
\text { encontro? }\end{array}$ & $\begin{array}{l}\text { Como ficou } \\
\text { sabendo deste } \\
\text { evento? } \\
\text { (Preencher com } \\
\text { opções a segui } \\
\text { Convite de gestor } \\
\text { do projeto (GES) } \\
\text { Convite de }\end{array}$ & $\begin{array}{l}\text { Quais foram os } \\
\text { motivos pelos quais } \\
\text { você foi chamado } \\
\text { para participar do } \\
\text { evento? (Preencher } \\
\text { com opções a seguir: } \\
\text { Indicação (IND) } \\
\text { Conhecia os gestores }\end{array}$ & $\begin{array}{l}\text { Quais são as suas } \\
\text { demandas, } \\
\text { necessidades e/ou } \\
\text { preferências, } \\
\text { relacionadas às } \\
\text { atividades } \\
\text { desenvolvidas no } \\
\text { projeto de }\end{array}$ & $\begin{array}{l}\text { Caso nesse encontro tenham sido } \\
\text { discutidas as demandas, } \\
\text { necessidades e preferências dos } \\
\text { durante o evento, alguma delas foi } \\
\text { incorporada no projeto de } \\
\text { restauração? Se sim, qual? }\end{array}$ \\
\hline
\end{tabular}




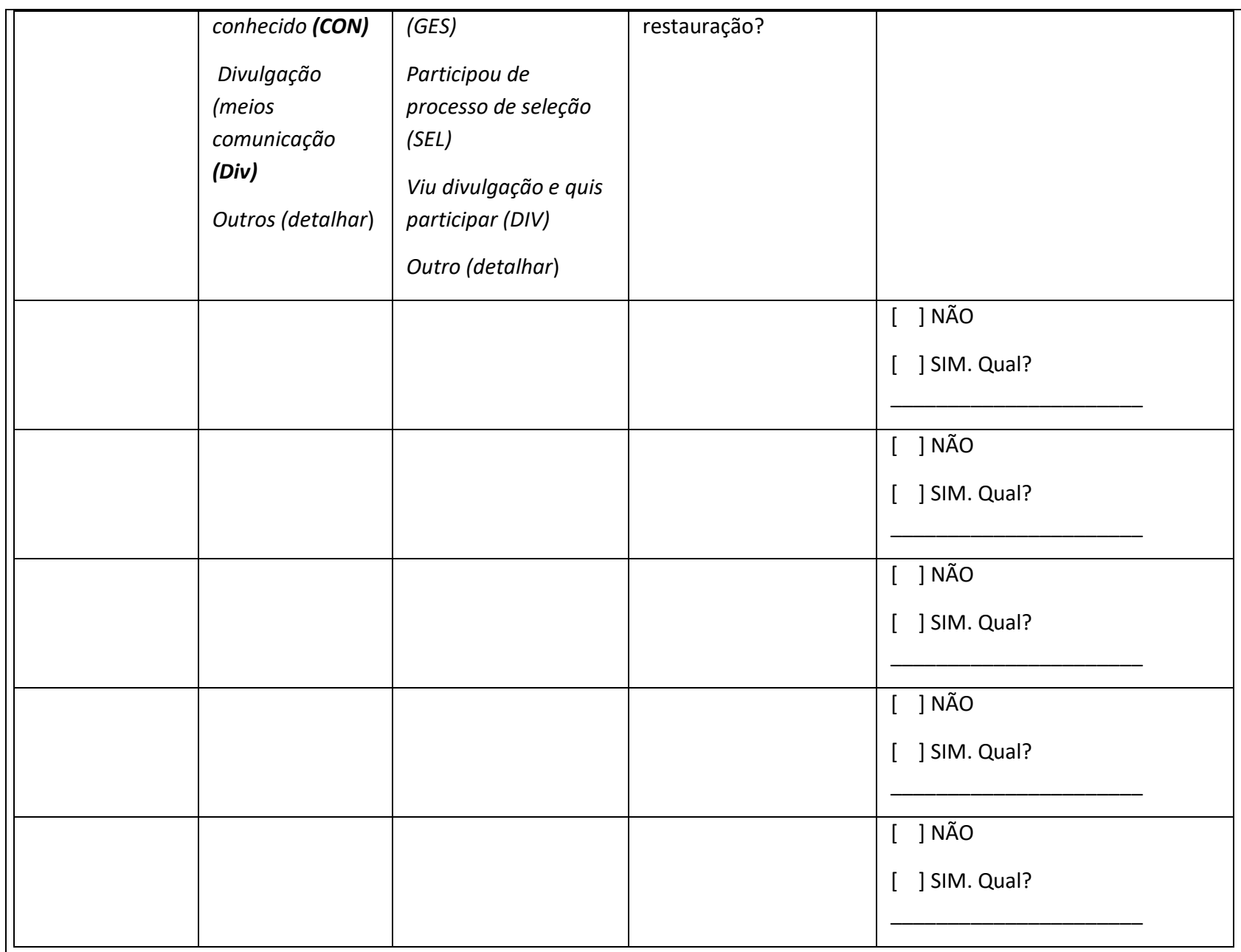

Com base, principalmente nestas demandas e necessidades, existem conflitos de opinião entre as pessoas envolvidas no projeto de restauração? Ou seja, há assuntos sobre os quais os participantes discordaram, sejam estes tanto os moradores, os proponentes ou então de outros órgãos?

[ ] NÃO [ ]SIM

\begin{tabular}{|l|l|l|}
\hline $\begin{array}{l}\text { Se sim, sobre qual tema existe } \\
\text { conflito? }\end{array}$ & $\begin{array}{l}\text { Qual o conflito existente em relação ao tema em } \\
\text { questão? }\end{array}$ & $\begin{array}{l}\text { Entre quais grupos participantes } \\
\text { ocorre este conflito? Por } \\
\text { exemplo, entre proprietários de } \\
\text { pequenas e de grandes } \\
\text { propriedades. }\end{array}$ \\
\hline & & \\
\hline & & \\
\hline & & \\
\hline
\end{tabular}

Caso tenha participado de eventos ou reuniões, durante estes momentos ocorreram situações de conflito de opinião entre os participantes? [ ] NÃO [ ]SIM

Se ocorreram conflitos de opinião, sobre quais assuntos eles ocorreram?
Os gestores do projeto tomaram alguma medida para resolver este
Qual medida foi tomada para resolver este conflito de opinião? 


\begin{tabular}{|c|c|c|}
\hline & conflito? & \\
\hline & [ ] ]Ñ̃O [ ] SIM & \\
\hline & [ ] ]NÃO [ ] SIM & \\
\hline & [ ] ]NÃO [ ] SIM & \\
\hline & [ ] ]NÃO [ ] SIM & \\
\hline & [ ] ]NÃO [ ] SIM & \\
\hline & [ ] ]NÃO [ ] SIM & \\
\hline $\begin{array}{l}\text { Antes de participar do projeto de re } \\
\text { desenvolvidas nele? Ou seja, conhecin } \\
\text { mudas das árvores e outras plantas e } \\
\text { sobre a manutenção ou cuidado com o } \\
\text { [ ] NÃO [ ] SIM }\end{array}$ & $\begin{array}{l}\text { tauração, o(a) senhor(a) já possı } \\
\text { ento de aspectos como, por exem } \\
\text { colhidas; conhecimento sobre a } \\
\text { plantios; ou, por fim, da exploraçâ }\end{array}$ & $\begin{array}{l}\text { conhecimento relacionado às atividades que foram } \\
\text {, o local ou a forma que deve ser feito o plantio das } \\
\text { paração do solo para o plantio; outras informações } \\
\text { los plantios depois? }\end{array}$ \\
\hline $\begin{array}{l}\text { Se sim, sobre quais atividades o(a) } \\
\text { senhor(a) já possuía conhecimento? }\end{array}$ & $\begin{array}{l}\text { Este conhecimento que você } \\
\text { tinha foi levado em conta pelos } \\
\text { gestores do projeto na hora de } \\
\text { decidir como as atividades de } \\
\text { restauração seriam } \\
\text { desenvolvidas? }\end{array}$ & $\begin{array}{l}\text { Se sim, como o seu conhecimento foi incluído no } \\
\text { projeto de restauração pelos gestores? Por } \\
\text { exemplo, ajudou a definir quais as melhores } \\
\text { espécies a serem usadas no plantio, maneiras de } \\
\text { evitar a ocorrência de determinadas pragas ou } \\
\text { doenças. }\end{array}$ \\
\hline & [ ] ]NÃO [ ] SIM & \\
\hline & [ ] ]NÃO [ ] SIM & \\
\hline & [ ] NÃO [ ] SIM & \\
\hline & [ ] NÃO [ ] SIM & \\
\hline & [ ] NÃO [ ] SIM & \\
\hline & [ ] ]NÃO [ ] SIM & \\
\hline $\begin{array}{l}\text { Desde a fase de planejamento do proje } \\
\text { comunicação para poder conseguir inf } \\
\text { nome e telefone de contato de alguém } \\
\text { [ ] NÃO [ ] SIM }\end{array}$ & $\begin{array}{l}\text { o de restauração até hoje, o(a) ser } \\
\text { mações projeto de restauração, o } \\
\text { algum whatsapp, um site da inter }\end{array}$ & $\begin{array}{l}\mathrm{r}(\mathrm{a}) \text { teve conhecimento sobre algum canal de } \\
\text { ntão tirar dúvidas e fazer sugestões? Por exemplo, o } \\
\text { ou internet, um escritório para ir conversar? }\end{array}$ \\
\hline Se sim, quais canais foram disponibi & $s$ pelas pessoas do projeto $p$ & em contato? \\
\hline
\end{tabular}




\begin{tabular}{|c|c|c|c|c|}
\hline 1) & ${ }^{21}$ & & & \\
\hline \multicolumn{5}{|c|}{$\begin{array}{l}\text { PARTE C - RESULTADOS } \\
\text { Agora, gostaríamos de falar sobre os impactos gerados pelo projeto par }\end{array}$} \\
\hline \multicolumn{5}{|c|}{$\begin{array}{l}\text { O(a) senhor(a) utiliza para consumo próprio ou vende algum produto, cultivo ou plantio da área de restauração desse projeto? [ } \\
\text { ] NÃO [ ] SIM }\end{array}$} \\
\hline $\begin{array}{l}\text { Se sim, por favor, } \\
\text { gostaria que o } \\
\text { senhor(a) me } \\
\text { dissesse qual é o } \\
\text { principal produto, } \\
\text { cultivo ou plantio } \\
\text { que usa? } \\
\text { E depois desse, há } \\
\text { mais algum } \\
\text { produto ou } \\
\text { plantio? }\end{array}$ & $\begin{array}{l}\text { Como o(a) senhor(a) } \\
\text { usa etiliza estes } \\
\text { cultivos? Consumo } \\
\text { próprio (CONS) } \\
\text { Comercialização } \\
\text { (COM) } \\
\text { Troca por outros } \\
\text { produtos com pessoas } \\
\text { da região (TRO) } \\
\text { Outros (OUT) }\end{array}$ & $\begin{array}{l}\text { Se o senhor(a) vende } \\
\text { este produto, para que } \\
\text { tipo de comprador? } \\
\text { Empresa (EMP) } \\
\text { ONG (ONG) } \\
\text { Moradores Locais } \\
\text { (MOR) } \\
\text { Comerciantes Locais } \\
(\mathrm{COM})\end{array}$ & $\begin{array}{l}\text { Se o senhor(a) } \\
\text { vende, quanto } \\
\text { dinheiro } \\
\text { conseguiu no } \\
\text { totalno de um } \\
\text { ano, ou seja, de } \\
\text { hoje? até }\end{array}$ & $\begin{array}{l}\text { Se utiliza para } \\
\text { consumo próprio, } \\
\text { quanto dinheiro o(a) } \\
\text { senhor(a) acredita que } \\
\text { deixou de gastar no } \\
\text { período de um ano, ou } \\
\text { seja, de } \\
\text { hoje? Ou seja, quanto } \\
\text { teria gastado se } \\
\text { comprasse o produto? }\end{array}$ \\
\hline & $\begin{array}{l}\text { CONS: }\left|\_\right| \\
\text {COM: }\left|\_\right| \\
\text {TROC: }\left|\_\right| \\
\text {Outros: }\end{array}$ & 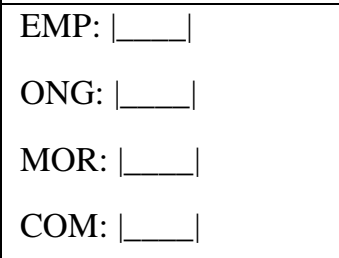 & $\left.\mathrm{R} \$\right|_{-}$ & $\left.\mathrm{R} \$\right|_{1}$ \\
\hline & 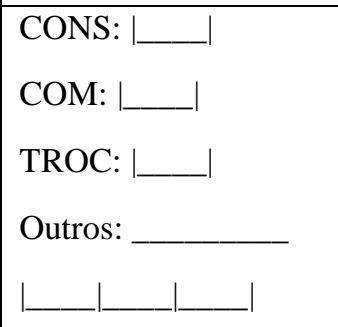 & 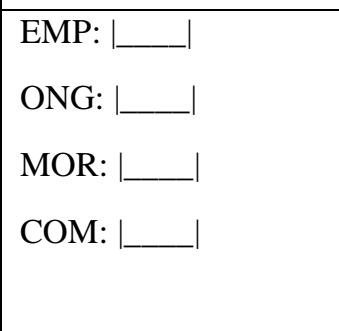 & $\left.\mathrm{R} \$\right|_{-}$ & _ \\
\hline & $\begin{array}{l}\text { CONS: }\left|\_\right| \\
\text {COM: }\left|\_\right| \\
\text {TROC: }\left|\_\right| \\
\text {Outros: }\end{array}$ & 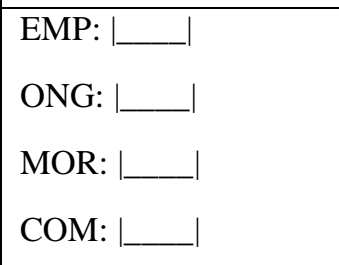 & $\left.\mathrm{R} \$\right|_{-}$ & $\left.\mathrm{R} \$\right|_{1}$ \\
\hline & $\begin{array}{l}\text { CONS: }\left|\_\right| \\
\text {COM: }\left|\_\right| \\
\text {TROC: }\left|\_\right| \\
\text {Outros: }\end{array}$ & 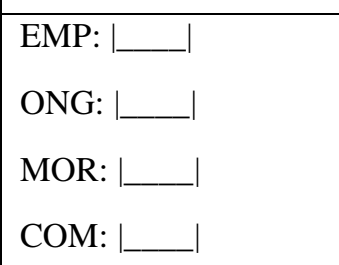 & $\left.\mathrm{R} \$\right|_{-}$ & $\left.\mathrm{R} \$\right|_{1}$ \\
\hline
\end{tabular}




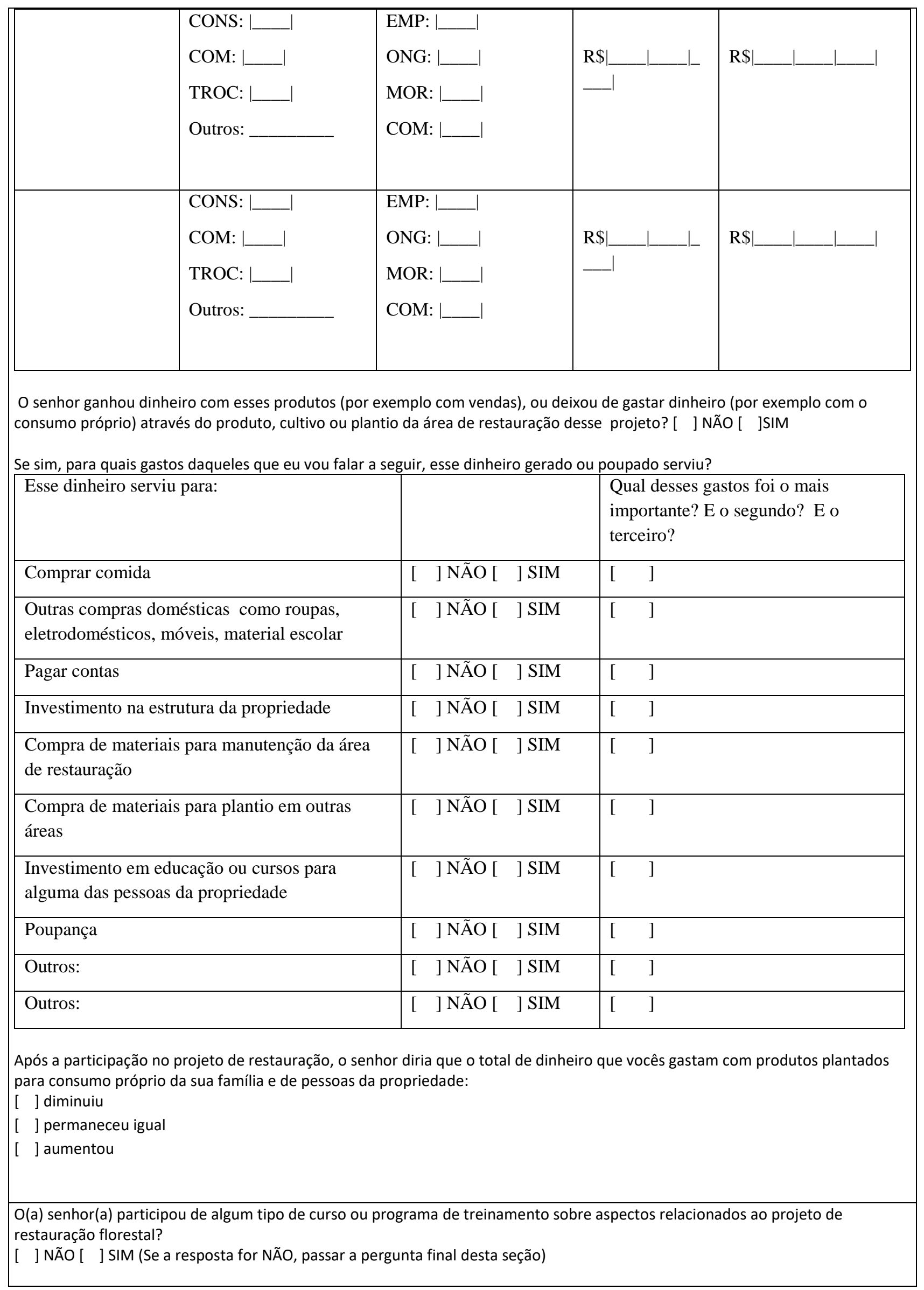




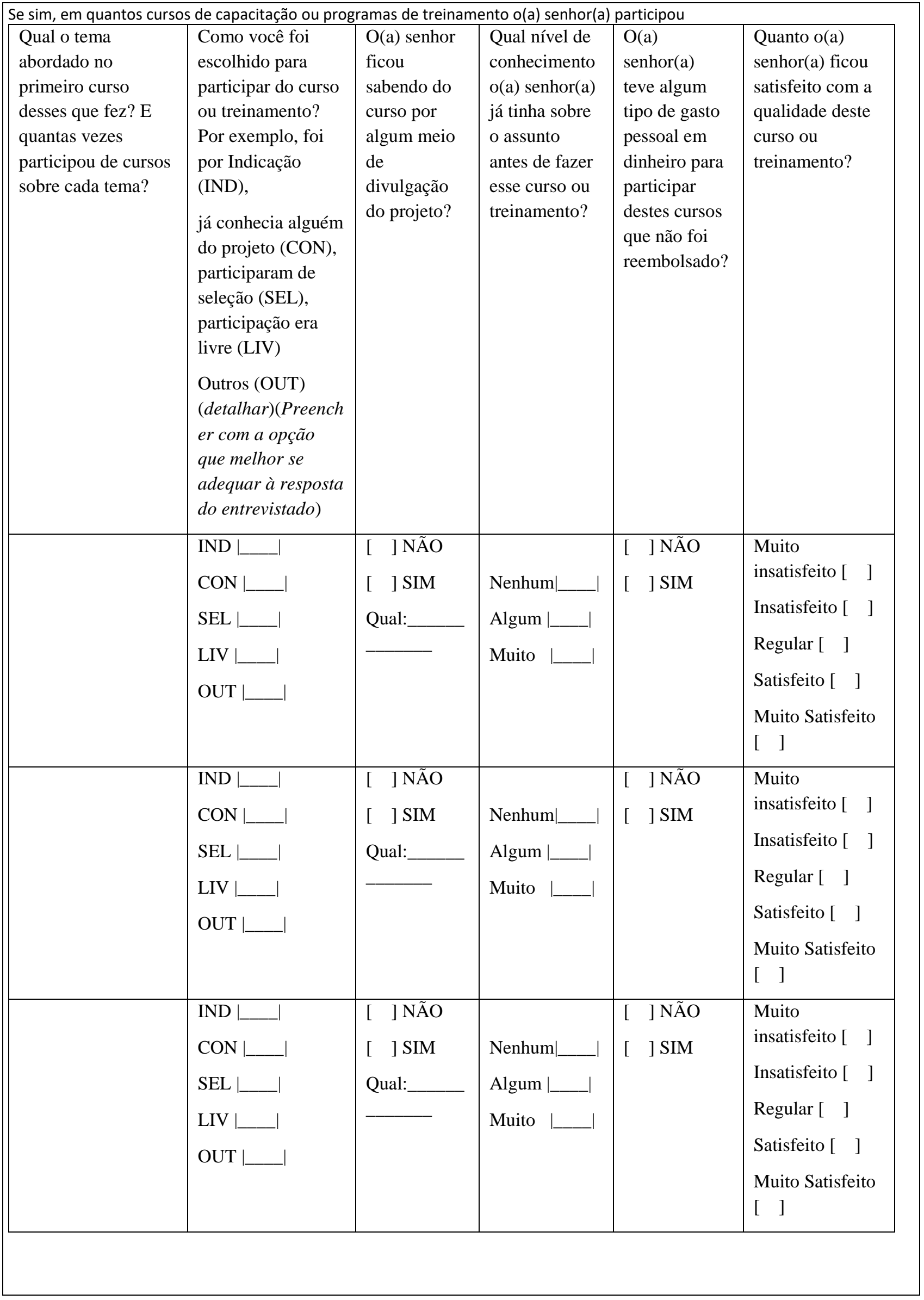


Existe algum assunto que não foi tratado nesses cursos já oferecidos e que o(a) senhor(a) acha que seria útil para as atividades ligadas à restauração?

[ ] NÃO

[ ] SIM. Qual?

(Fazer esta pergunta apenas se a resposta da primeira questão sobre este tema for $N A ̃ O) ~ O(a)$ senhor(a) gostaria de ter participado de algum curso voltado para as atividades que são desenvolvidas na sua propriedade e na área de restauração? [ ]NÃO [ ] SIM Se sim, qual(is) tema(s) o(a) senhor(a) tem interesse em aprender?

1.

2.

3.

4.

5.

6.

7.

8.

Agora, eu gostaria de saber se o(a) senhor(a) já recebeu algum tipo de assistência técnica com as atividades necessárias para o plantio e a manutenção da área de restauração. Ou seja, se alguma pessoa com conhecimento técnico sobre essas atividades já forneceu algum tipo de orientação. [ ] ] NÃO [ ] SIM

\begin{tabular}{|c|c|c|}
\hline $\begin{array}{l}\text { Se sim, sobre qual assunto } \\
\text { o(a) senhor(a) já recebeu } \\
\text { orientação ou assistência ao } \\
\text { menos uma vez? }\end{array}$ & $\begin{array}{l}\text { Essa assistência é fornecida por quem? } \\
\text { Gestores do projeto (GES) } \\
\text { Empresas contratadas (EMP) } \\
\text { Estudantes/Acadêmicos (EST) } \\
\text { ONGs (ONG) } \\
\text { Outro (OUT) (definir) }\end{array}$ & $\begin{array}{l}\text { O quanto o(a) senhor(a) está satisfeito } \\
\text { com a qualidade desta assistência? } \\
\text { Muito insatisfeito (MIN) Insatisfeito } \\
\text { (INS), Regular (REG), Satisfeito } \\
\text { (SAT), Muito Satisfeito (MSA) } \\
\text { (Preencher com a sigla } \\
\text { correspondente) }\end{array}$ \\
\hline & 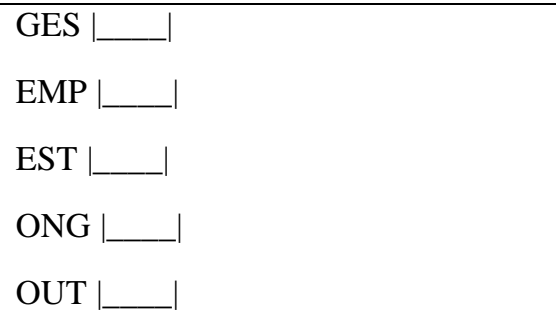 & $\begin{array}{l}\text { Muito insatisfeito [ ] } \\
\text { Insatisfeito [ ] } \\
\text { Regular [ ] } \\
\text { Satisfeito [ ] } \\
\text { Muito Satisfeito [ ] }\end{array}$ \\
\hline
\end{tabular}




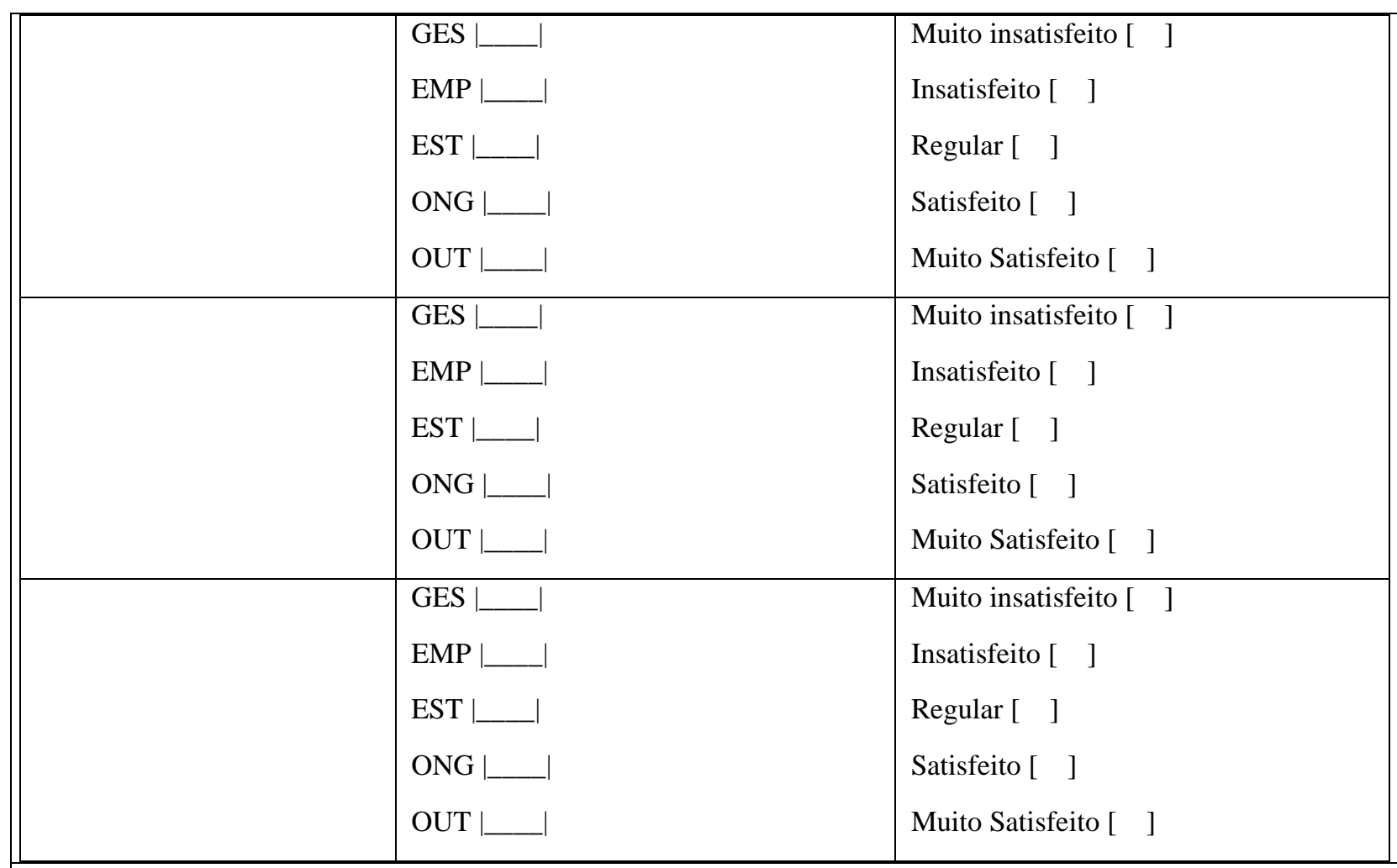

Ter participado do(s) curso(s) contribuiu para que o senhor(a) passasse a fazer alguma atividade ou plantar algum produto que antes o(a) senhor(a) não conhecia ou sabia fazer?

[ ] NÃO

[ ] SIM. Qual?

Após participar do(s) curso(s) ou treinamento, o senhor(a) percebeu que aumentaram as oportunidades de trabalho ou de ganhar dinheiro por causa de assuntos aprendidos durante esses cursos? [ ] NÃO [ ] SIM.

\begin{tabular}{|l|l}
\hline Se sim, quais são os trabalhos que o senhor já realizou desde & Quanto o senhor(a) ganhou em dinheiro por
\end{tabular} (dizer dia e mês equivalente ao do ano anterior) até hoje que foram consequência desse curso ou treinamento?

Por favor, cite todos, começando com aquele mais importante. realizar este trabalho desde (dizer dia $e$ mês equivalente ao do ano anterior) do ano passado até o dia de hoje?

\begin{tabular}{|l|l|}
\hline & \\
\hline & \\
\hline & \\
\hline & \\
\hline & \\
\hline & \\
\hline & \\
\hline
\end{tabular}

Se sim, como vocês costumam gastar o dinheiro que conseguem através da realização destes trabalhos?

\begin{tabular}{|l|l|l|}
\hline $\begin{array}{l}\text { Compras domésticas: como alimento, roupas, } \\
\text { móveis, eletrodomésticos }\end{array}$ & [ ] NÃO [ ] SIM & Especificar: \\
\hline Investimento na estrutura da propriedade & [ ] NÃO [ ] SIM & Especificar: \\
\hline Compra de materiais para manutenção da área de & [ ] NÃO [ ] SIM & Especificar: \\
\hline
\end{tabular}




\begin{tabular}{||l|l|l|}
\hline restauração & & \\
\hline Compra de materiais para plantio em outras áreas & [ ] NÃO [ ] SIM & Especificar: \\
\hline Investimento em educação/cursos & [ ] NÃO [ ] SIM & Especificar: \\
\hline Poupança & [ ] NÃO [ ] SIM & Especificar: \\
\hline Outros: & [ ] NÃO [ ] SIM & Especificar: \\
\hline Outros: & [ ] NÃO [ ] SIM & Especificar: \\
\hline
\end{tabular}

Qual(is) atividade(s) vocês costumavam fazer no tempo livre, ou seja, atividades para se divertir ou descansar antes de participar do projeto de restauração? Por favor, cite em ordem de importância, ou seja, daquelas mais frequentes para menos frequentes.

\begin{tabular}{|l|}
\hline 1. \\
\hline 2. \\
\hline 3. \\
\hline 4. \\
\hline 5. \\
\hline 6. \\
\hline
\end{tabular}

Houve alguma mudança nas atividades realizadas durante o tempo livre de vocês que foram um resultado direto ou indireto do projeto de restauração? Por exemplo, houve alguma atividade que, por conta do projeto, vocês passaram a fazer ou alguma que tiveram que deixar de fazer no tempo livre?

[ ] ] NÃO

[ ] ] SIM. O que

ocorreu?

Por favor, conte-me um pouco porque o(a) senhor(a) decidiu aceitar participar do projeto de restauração.

Hoje, o(a) senhor(a) considera que o projeto de restauração trouxe algum retorno positivo para o(a) senhor(a), sua família ou propriedade, ou seja, que ter participado do projeto de restauração gerou algum benefício para vocês? [ ] NÃO [ ] SIM Se sim, quais foram os retornos positivos em ordem de importância?

\begin{tabular}{|l|}
\hline 1. \\
\hline 2. \\
\hline 3. \\
\hline 4. \\
\hline 5. \\
\hline 6. \\
\hline
\end{tabular}

E gerou impactos negativos, ou seja, algum resultado ou situação que não beneficiaram o(a) senhor(a), sua família ou propriedade? [ ] NÃO [ ] SIM

Se sim, quais foram os impactos negativos em ordem de importância?

$$
1 .
$$

2.

3. 


\begin{tabular}{|l|l|}
\hline & 4. \\
\hline 5. & \\
\hline 6. & \\
Se o senhor(a) fosse convidado hoje para participar de um novo de projeto de restauração, aceitaria? [ ] NÃO [ ] SIM \\
Se não, por que não? __ \\
Das opções que eu vou falar, se o senhor(a) tivesse que escolher que escolher hoje, o que faria: \\
[ ] ] manteria a área de restauração como está \\
{$[\quad]$ usaria a área de restauração para outra finalidade. Qual?___ }
\end{tabular}

\section{PARTE D - MONITORAMENTO}

Nesta parte gostaríamos de conversar sobre o processo de monitoramento desenvolvido no projeto de restauração.

$\mathrm{O}$ (a) senhor(a) sabe se são realizadas atividades de monitoramento, ou seja, atividades para acompanhar o que está acontecendo na área de plantio de árvores ou restauração como, por exemplo, para avaliar se o plantio está dando certo ou o que ocorreu?

\section{[ ] NÃO [ ] SIM}

E tem ocorrido algum acompanhamento ou avaliação de tempos em tempos dos efeitos que a participação no projeto de restauração teve para o bem-estar de vocês que participaram? Mesmo que este monitoramento não seja feito diretamente com o(a) senhor(a) ou na sua propriedade. [ ] NÃO [ ] SIM

\begin{tabular}{|c|c|c|c|c|}
\hline $\begin{array}{l}\text { Se houve } \\
\text { monitorament } \\
\text { o ou } \\
\text { acompanhame } \\
\text { nto, por favor, } \\
\text { diga cada um } \\
\text { dos aspectos } \\
\text { que já foram } \\
\text { verificados } \\
\text { com o(a) } \\
\text { senhor(a) ou } \\
\text { outras pessoas } \\
\text { desta } \\
\text { propriedade. }\end{array}$ & $\begin{array}{l}\text { Com qual frequência } \\
\text { realizam este } \\
\text { monitoramento? Por } \\
\text { exemplo: mensal } \\
\text { (MEN), semestral } \\
\text { (SEMES), anual } \\
\text { (ANUAL), somente } \\
\text { uma vez ou duas } \\
\text { vezes (1-2) } \\
\text { (Preencher com a } \\
\text { opção mais próxima à } \\
\text { resposta do } \\
\text { entrevistado ou } \\
\text { anotar por extenso, se } \\
\text { diferir muito) }\end{array}$ & $\begin{array}{l}\text { Com base na lista que eu } \\
\text { vou te falar, me diga por } \\
\text { favor como fizeram para } \\
\text { acompanhar este aspecto } \\
\text { nesta propriedade } \\
\text { - Eles coletaram } \\
\text { informações na área } \\
\text { diretamente(CAMPO) } \\
\text { - Perguntaram em conversa } \\
\text { com alguém da propriedade } \\
\text { (ENTREV) } \\
\text { - Entregaram uma lista de } \\
\text { perguntas no papel } \\
\text { (QUEST) } \\
\text { - Perguntaram durante uma } \\
\text { reunião (GRUPO) } \\
\text { - Outra forma? } \\
\text { Qual? }\end{array}$ & $\begin{array}{l}\text { Este monitoramento é } \\
\text { realizado por quem? Favor } \\
\text { informar se são: moradores } \\
\text { locais (LOC), pessoas que } \\
\text { fazem parte da gestão do } \\
\text { projeto (GEST), } \\
\text { pesquisadores (PESQ) ou } \\
\text { outros (OUT). } \\
\text { Do total de pessoas que } \\
\text { fizeram esse } \\
\text { acompanhamento, quantas } \\
\text { eram homens e quantas } \\
\text { mulheres?. } \\
\text { (Preencher com sigla mais } \\
\text { próxima ou escrever por } \\
\text { extenso. Calcular a } \\
\text { proporção) }\end{array}$ & $\begin{array}{l}\text { Vocês receberam } \\
\text { retorno sobre os } \\
\text { resultados dessa } \\
\text { avaliação? Ou seja, } \\
\text { alguém veio contar } \\
\text { a vocês ou trouxe } \\
\text { material escrito com } \\
\text { informações sobre o } \\
\text { que vem ocorrendo } \\
\text { na propriedade de } \\
\text { vocês e nas outras } \\
\text { que foram } \\
\text { avaliadas? }\end{array}$ \\
\hline & MENSAL: | & CAMPO: & [ ] LOC: & {$\left[\begin{array}{ll}] & ]\end{array}\right.$} \\
\hline
\end{tabular}




\begin{tabular}{|c|c|c|c|c|}
\hline & $\begin{array}{l}\text { SEMESTRAL: }\left|\_\right| \\
\text {ANUAL: }\left|\_\right| \\
\text {1-2 VEZES: }\left|\_\right| \\
\text {Outro: } \\
+\mid\end{array}$ & $\begin{array}{l}\text { ENTREVISTA: }\left|\_\right| \\
\text {QUESTIONÁRIO: }\left|\_\right| \\
\text {GRUPO: }\left|\_\right| \\
\text {OUTRO: }\end{array}$ & $\begin{array}{l}\text { [ ] GEST: } \% \mathrm{H}: \\
\text { [ ] PESQ: } \% \mathrm{H}: \\
\text { [ ] OUT: } \% \mathrm{H}:\end{array}$ & SIM \\
\hline & $\begin{array}{l}\text { MENSAL: }\left|\_\right| \\
\text {SEMESTRAL: }\left|\_\right| \\
\text {ANUAL: }\left|\_\right| \\
\text {1-2 VEZES: }\left|\_\right| \\
\text {Outro: } \\
\_\mid\end{array}$ & $\begin{array}{l}\text { CAMPO: }\left|\_\right| \\
\text {ENTREVISTA: }\left|\_\right| \\
\text {QUESTIONÁRIO: }\left|\_\right| \\
\text {GRUPO: }\left|\_\right| \\
\text {OUTRO: } \\
\end{array}$ & $\begin{array}{l}\text { [ ] LOC: } \% \mathrm{H}: \\
\text { [ ] GEST: } \% \mathrm{H}: \\
\text { [ ] PESQ: } \% \mathrm{H}: \\
\text { [ ] OUT: } \% \mathrm{H}:\end{array}$ & $\begin{array}{l}\text { [ ] NÃO [ ] } \\
\text { SIM }\end{array}$ \\
\hline & $\begin{array}{l}\text { MENSAL: }\left|\_\right| \\
\text {SEMESTRAL: }\left|\_\right| \\
\text {ANUAL: }\left|\_\right| \\
\text {1-2 VEZES: }\left|\_\right| \\
\text {Outro: } \\
\_\mid\end{array}$ & $\begin{array}{l}\text { CAMPO: }\left|\_\right| \\
\text {ENTREVISTA: }\left|\_\right| \\
\text {QUESTIONÁRIO: } \mid \text { __ } \mid \\
\text { GRUPO: }\left|\_\right| \\
\text {OUTRO: } \\
\end{array}$ & $\begin{array}{l}\text { [ ] LOC: } \% \mathrm{H:} \\
\text { [ ] GEST: } \% \mathrm{H}: \\
\text { [ ] PESQ: } \% \mathrm{H}: \\
\text { [ ] OUT: } \% \mathrm{H}:\end{array}$ & $\begin{array}{l}\text { [ ] NÃO [ ] } \\
\text { SIM }\end{array}$ \\
\hline & $\begin{array}{l}\text { MENSAL: }\left|\_\right| \\
\text {SEMESTRAL: }\left|\_\right| \\
\text {ANUAL: }\left|\_\right| \\
\text {1-2 VEZES: }\left|\_\right| \\
\text {Outro: } \\
\_\mid\end{array}$ & $\begin{array}{l}\text { CAMPO: }\left|\_\right| \\
\text {ENTREVISTA: } \mid \_ \text {__ } \\
\text { QUESTIONÁRIO: }\left|\_\right| \\
\text {GRUPO: }\left|\_\right| \\
\text {OUTRO: } \\
\end{array}$ & $\begin{array}{l}\text { [ ] LOC: } \% \mathrm{H}: \\
\text { [ ] GEST: } \% \mathrm{H}: \\
\text { [ ] PESQ: } \% \mathrm{H}: \\
\text { [ ] OUT: } \% \mathrm{H}:\end{array}$ & $\begin{array}{l}\text { [ ] NÃO [ ] } \\
\text { SIM }\end{array}$ \\
\hline $\begin{array}{l}\text { plantada com } \\
\text { [ ] ocupa un } \\
\text { plantadas não } \\
\text { [ ] ocupa um } \\
\text { plantadas fora } \\
\text { [ ] ocupa a n } \\
\text { sobreviveram } \\
\text { [ ] ocupa um }\end{array}$ & $\begin{array}{l}\text { area na sua proprie } \\
\text { spécies nativas/ag } \\
\text { la área menor em } \\
\text { sobreviveram } \\
\text { a área menor em t } \\
\text { m cortadas. } \\
\text { lesma área do que } \\
\text { área maior do que }\end{array}$ & $\begin{array}{l}\text { lade onde o projeto de } \\
\text { floresta: (selecionar } n \\
\text { manho do que na épo } \\
\text { manho do que na épo } \\
\text { la época do plantio, ou } \\
\text { na época do plantio, ou }\end{array}$ & $\begin{array}{l}\text { stauração foi realizado, v } \\
\text { de uma opção, se for o } \\
\text { do plantio? Ou seja, muite } \\
\text { do plantio? Ou seja, muite } \\
\text { eja, a maioria das árvores } \\
\text { aja, foi feito novo plantio }\end{array}$ & $\begin{array}{l}\text { cê acha que a área } \\
\text { aso) } \\
\text { s árvores que foram } \\
\text { s árvores que foram } \\
\text { que foram plantadas } \\
\text { m nova área }\end{array}$ \\
\hline $\begin{array}{l}\text { Caso a área } \mathrm{c} \\
\text { ocorreu para } \mathrm{q}\end{array}$ & restauração es & $\begin{array}{l}\text { menor do que estav } \\
\text { esse? }\end{array}$ & ialmente, o que o(a) se & hor(a) acredita qu \\
\hline Mortalidade & & & [ ]NÃO [ ] & IIM \\
\hline Queimadas & & & [ ]NÃO [ ] ] & $\overline{\mathrm{IIM}}$ \\
\hline Corte de árvo & & & [ ]NÃO [ ] & \\
\hline Falhas no pla & & & [ ]NÃO [ ] & IIM \\
\hline Entrada de al & imais na área & & [ ]NÃO [ & \\
\hline
\end{tabular}




\begin{tabular}{|l|l|}
\hline Outros & {$[$ ]NÃO [ ] SIM } \\
\hline Não Sei & {$[$ ] } \\
\hline
\end{tabular}

Durante o período em que foram realizadas as atividades do projeto de restauração, vocês receberam algum dinheiro ou financiamento para auxiliar na aquisição de materiais ou outras atividades necessárias para sua participação?

[ ] NÃO [ ] SIM

Se sim, com quais atividades que eu vou te falar esse dinheiro foi utilizado? Favor indicar as atividades começando por aquelas que receberam mais recursos . (responderam nas 2 primeiras colunas da tabela)

Durante o período em que foram realizadas as atividades do projeto de restauração, vocês receberam doação de algum material ou ajuda com mão-de-obra que eram necessários para sua participação?

[ ] NÃO [ ] SIM

Se sim, quais materiais vocês receberam como doação? E ajuda com mão-de-obra para o plantio? (anotar nas duas últimas colunas)

\begin{tabular}{|c|c|c|c|}
\hline Atividade (aquisição ou contratação) & $\begin{array}{l}\text { Receberam } \\
\text { financiamento? }\end{array}$ & 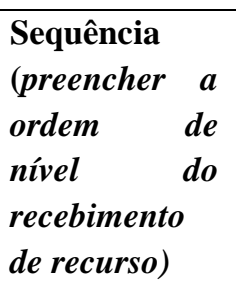 & $\begin{array}{l}\text { Receberam } \\
\text { diretamente? }\end{array}$ \\
\hline Mudas & [ ] ] NÃO [ ] SIM & & [ ] ] NÃO [ ] SIM \\
\hline Materiais para construção de cerca & [ ] NÃO [ ] SIM & & [ ] NÃO \\
\hline Materiais necessários ao plantio & [ ] ] NÃO [ ] SIM & & [ ] NÃO \\
\hline $\begin{array}{l}\text { Mão-de-Obra para o plantio: } \\
\text { De quem? }\end{array}$ & [ ] NÃO [ ] SIM & & [ ] NÃO \\
\hline Outros: & [ ] NÃO & & [ ] NÃO \\
\hline Outros: & [ ] NÃO & & [ ] NÃO \\
\hline
\end{tabular}

\section{PARTE E - CARACTERIZAÇÃO DA PROPRIEDADE E RESIDENTES}

Nesta parte final, farei algumas perguntas sobre a sua propriedade e as pessoas que vivem nela.

O senhor(a) vive nesta propriedade, ou seja, passa a maior parte dos dias e das noites da semana nela?

[ ] NÃO vivo na propriedade.

[ ] NÃO, passo apenas o dia nesta propriedade, mas as noites em outro local. Há quantos anos completos você passa os dias nesta propriedade? | anos de residência

[ ] NÃO, passo apenas a noite nesta propriedade, mas os dias em outro local. Há quantos anos completos você passa as noites nesta propriedade? | | anos de residência 
[ ] SIM. Se sim, há quantos anos completos você vive nesta propriedade? | anos de residência

Existe alguma pessoa que vive há mais tempo que o senhor(a) nesta propriedade?

[ ] NÃO

[ ] SIM. Se sim, há quantos anos completos essa pessoa vive nesta propriedade? | _ _ anos de residência

Nos próximos 5 anos, ou seja, de agora até 2024, você tem a intenção de se mudar para outro local, em uma outra região rural ou até mesmo para alguma cidade? [ ] NÃO [ ] SIM

Quantas pessoas, incluindo o(a) senhor(a), vivem nesta propriedade, ou seja, passam a maior parte dos dias e/ou das noites da semana nela? pessoas

Destas pessoas, quantas têm menos de 15 anos? | crianças

E quantas dessas pessoas têm 15 anos de idade ou mais? adultos.

Dessas pessoas com mais de 15 anos, quantas têm algum problema ou limitação que as impede de trabalhar, ou seja, de exercerem atividades dentro ou fora da propriedade? adultos limitados.

Em qual cidade de qual estado o senhor(a) nasceu? Cidade: Estado:

Qual é a data de nascimento do senhor(a)? 119

Existe alguma pessoa que frequentou a escola por algum tempo nesta casa?

[ ] NÃO

[ ] SIM. Se sim, até qual série a pessoa que mais estudou na propriedade conseguiu chegar? série (escrever número da série)

Do: [ ] fundamental [ ] médio [ ] superior OUTRO(descrever):

E o senhor(a), frequentou a escola alguma vez na vida?

[ ] NÃO

[ ] SIM. Se sim, até qual série o senhor(a) conseguiu chegar? 


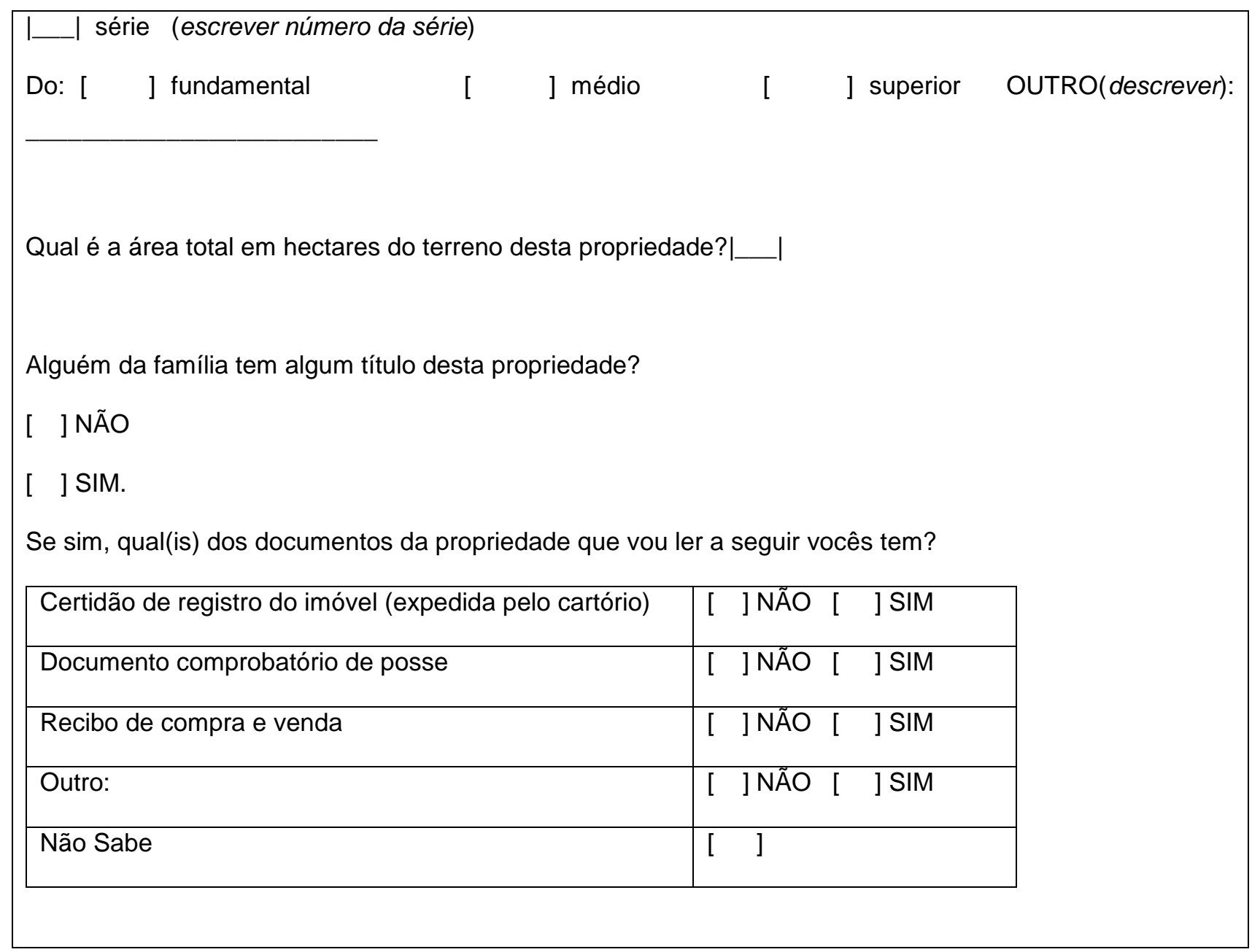




\section{INTRODUÇÃO PARA AS ENTREVISTAS (IMPRIMIR SOMENTE UMA VEZ)}

Olá,

Meu nome é e estou fazendo uma pesquisa para a Universidade de São Paulo. Queremos com essa pesquisa entender melhor algumas atividades realizadas na região do Paranapanema como, por exemplo, o plantio de árvores e o projeto "Café com Floresta", realizado em algumas propriedades por aqui.

Estamos fazendo entrevistas com moradores da região para saber se têm conhecimento sobre estas atividades e quem participou, além de informações sobre as possíveis consequências, tanto positivas quanto negativas, para as famílias da região. Nossa intenção é entender quais atividades dão certo e o que pode ser melhorado em projetos futuros.

Peço a gentileza de saber se eu poderia conversar com a pessoa desta família ou propriedade que é a principal responsável pela tomada de decisões. Essa conversa deve levar em torno de minutos.

Gostaria de deixar claro que não existe resposta certa ou errada: o que vale para a gente é a opinião de vocês sobre esses assuntos que vamos conversar. Nós não vamos contar a ninguém o que as pessoas disseram e vamos manter o nome das pessoas que responderam em segredo.

Antes de começar gostaria de entregar este Termo de Consentimento. Este papel é um documento que explica os objetivos da entrevista que eu acabei de te explicar. Tem também o endereço da universidade e telefone, caso você tenha alguma dúvida ou queira entrar em contato com a gente. Este Termo tem duas cópias iguais que nós dois assinamos. Eu assino garantindo que não divulgarei seu nome a ninguém e você assina se aceitar participar da entrevista. A via que estou te entregando já está assinada por mim e ficará guardada com você, a outra via ficará arquivada comigo. 


\begin{tabular}{|c|c|}
\hline \multirow{2}{*}{ 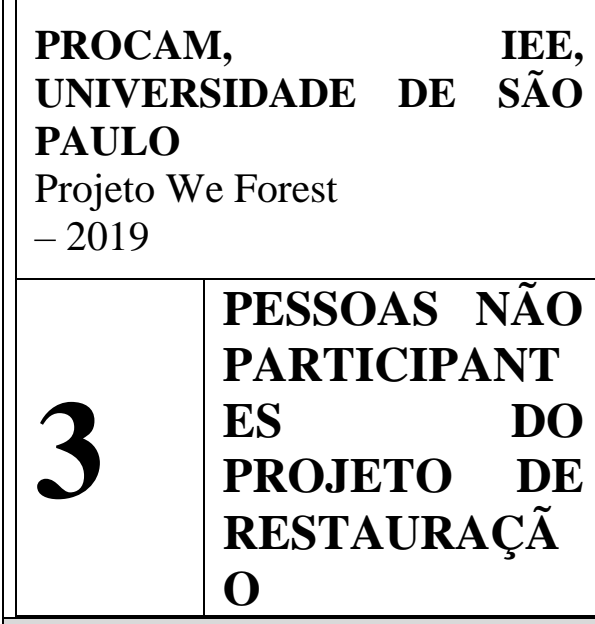 } & 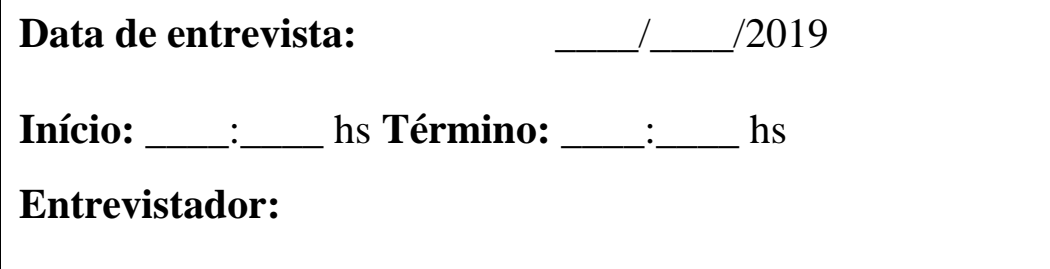 \\
\hline & $\begin{array}{l}\text { Nome } \quad \text { do entrevistado: } \\
\text { Gênero: }[\text { ] F } \quad[\quad] M \\
\text { Contato telefônico do entrevistado: } \\
\text { Local da Entrevista: }\end{array}$ \\
\hline $\begin{array}{r}\text { PARTE A - DEFINIÇÃO } \\
\text { Nesta parte inicial da entrevista, vam } \\
\text { restauração adotadas, bem como a esce } \\
\text { partic }\end{array}$ & $\begin{array}{l}\text { DE ESTRATÉGIAS E ÁREAS DE IMPLEMENTAÇÃO } \\
\text { os conversar sobre como ocorreram as decisões sobre as estratégias de } \\
\text { lha do local onde estas estratégias foram implementadas, e como foi sua } \\
\text { ipação e inclusão desta implementação. }\end{array}$ \\
\hline $\begin{array}{l}\text { O(a) senhor(a) sabe que na região do Pc } \\
\text { floresta e paisagem, ou seja, um projeto } \\
\text { vegetação em diferentes propriedades, vis } \\
\text { Se sim, da lista que vou te falar, qual foi c } \\
\text { a) Conhece alguma pessoa ou família o } \\
\text { ), conhece alguém que faz a gestão do projetc } \\
\text { I_I_ (Caso outros, detalhar }\end{array}$ & $\begin{array}{l}\text { ntal do Paranapanema está sendo realizado um projeto de restauração da } \\
\text { através do qual são realizados plantios de árvores nativas e outros tipos de } \\
\text { ando diminuir os danos ambientais na região? [ ]NÃO [ ]SIM } \\
\text { meio pelo qual o(a) senhor(a) ficou sabendo deste projeto de restauração? } \\
\text { ue participou ou participa do projeto (PAR)? Não I__ Sim I_l } \\
\text { (GES), através de divulgação por meios de comunicação (DIV), Outros (OUT): } \\
\text { ) }\end{array}$ \\
\hline \multicolumn{2}{|c|}{ Por favor, em qual ano o(a) senhor(a) ouviu falar sobre este projeto de restauração pela primeira vez: } \\
\hline $\begin{array}{l}\text { Dos tipos de atividades visando a restaur } \\
\text { falar o(a) senhor(a) ficou sabendo que occ } \\
\text { Conservação de remanescentes de mata, } \\
\text { [ ]NÃO [ ]SIM }\end{array}$ & $\begin{array}{l}\text { ção ambiental da paisagem ou das matas, quais dentre aquelas que eu vou } \\
\text { rreram aqui na região dentro deste projeto de Café com Floresta?: Ocorreu: } \\
\text { u seja, atividades para manter a mata que já existia em pé? }\end{array}$ \\
\hline $\begin{array}{l}\text { Regeneração natural, ou seja, deixar que } \\
\text { Condução de Regeneração Natural, ou se } \\
\text { volte a crescer onde existia? [ ]NÃO [ }\end{array}$ & $\begin{array}{l}\text { mata volte sozinha a crescer onde existia: [ ]NÃO [ ]SIM } \\
\text { ja, quando são feitas algumas atividades para ajudar ou facilitar que a mata } \\
\text { ]SIM }\end{array}$ \\
\hline $\begin{array}{l}\text { Restauração por plantio, ou seja, quando } \\
\text { Restauração por planto de Sistemas A }\end{array}$ & $\begin{array}{l}\text { foi feito o plantio de árvores nativas da mata da região? [ ]NÃO [ ]SIM } \\
\text { groflorestais, ou seja, de plantios que misturam árvores com produtos }\end{array}$ \\
\hline
\end{tabular}


agrícolas?: [ ]NÃO [ ]SIM

Práticas sustentáveis de agricultura, ou seja, incentivo a mudanças na forma de plantar para reduzir o impacto ambiental?: [ ]NÃO [ ]SIM

Existem outras atividades que o senhor(a) lembra que eu não falei? Quais?

1)

2)

Outros:

Existem hoje na sua propriedade fragmentos, ou seja, remanescentes, de vegetação natural como floresta que não tenham sofrido degradação ou permaneciam bem conservados? . [ ] NÃO [ ] SIM

Se sim, qual é o tamanho aproximado desta área, em hectares?

E qual a proporção do total da propriedade que é ocupada por esses remanescentes? [ ]$\%$

A implantação do projeto de restauração aqui na região trouxe alguma mudança para as atividades ou a forma como essas atividades são realizadas aqui na sua propriedade? [ ]NÃO [ ]SIM

INCLUIR VÁRIAS OUTRAS COISAS

Existem hoje áreas de agricultura na sua propriedade, ?

[ ]NÃO [ ] SIM

Se sim, das opções que eu vou te falar, por favor, me diga qual explica melhor a finalidade dos plantios que existem hoje:

[ ] Plantio para o consumo próprio das pessoas que vivem na propriedade.

[ ] Plantio para vender produtos agrícolas.

[ ] Ambos

Desde ANO houve mudanças nas práticas de agricultura que vocês usavam que tiveram como objetivo reduzir o impacto ambiental da atividade?

[ ] Não [ ] Sim

Se sim, por favor descreva quais foram os tipos de ações ou mudanças que ocorreram:

Essa mudanças tiveram influência direta ou indireta do projeto de restauração Cafè com Floresta que ocorreu na região?

[ ] Sim. Como?

Existem hoje áreas de pecuária na sua propriedade, ?

[ ]NÃO [ ] SIM

Desde ANO houve mudanças nas práticas de agricultura que vocês usavam que tiveram como objetivo reduzir o impacto ambiental da atividade?

[ ] Não [ ] Sim 
Se sim, por favor descreva quais foram os tipos de ações ou mudanças que ocorreram:

Essa mudanças tiveram influência direta ou indireta do projeto de restauração Cafè com Floresta que ocorreu na região?

[ ] Sim. Como?

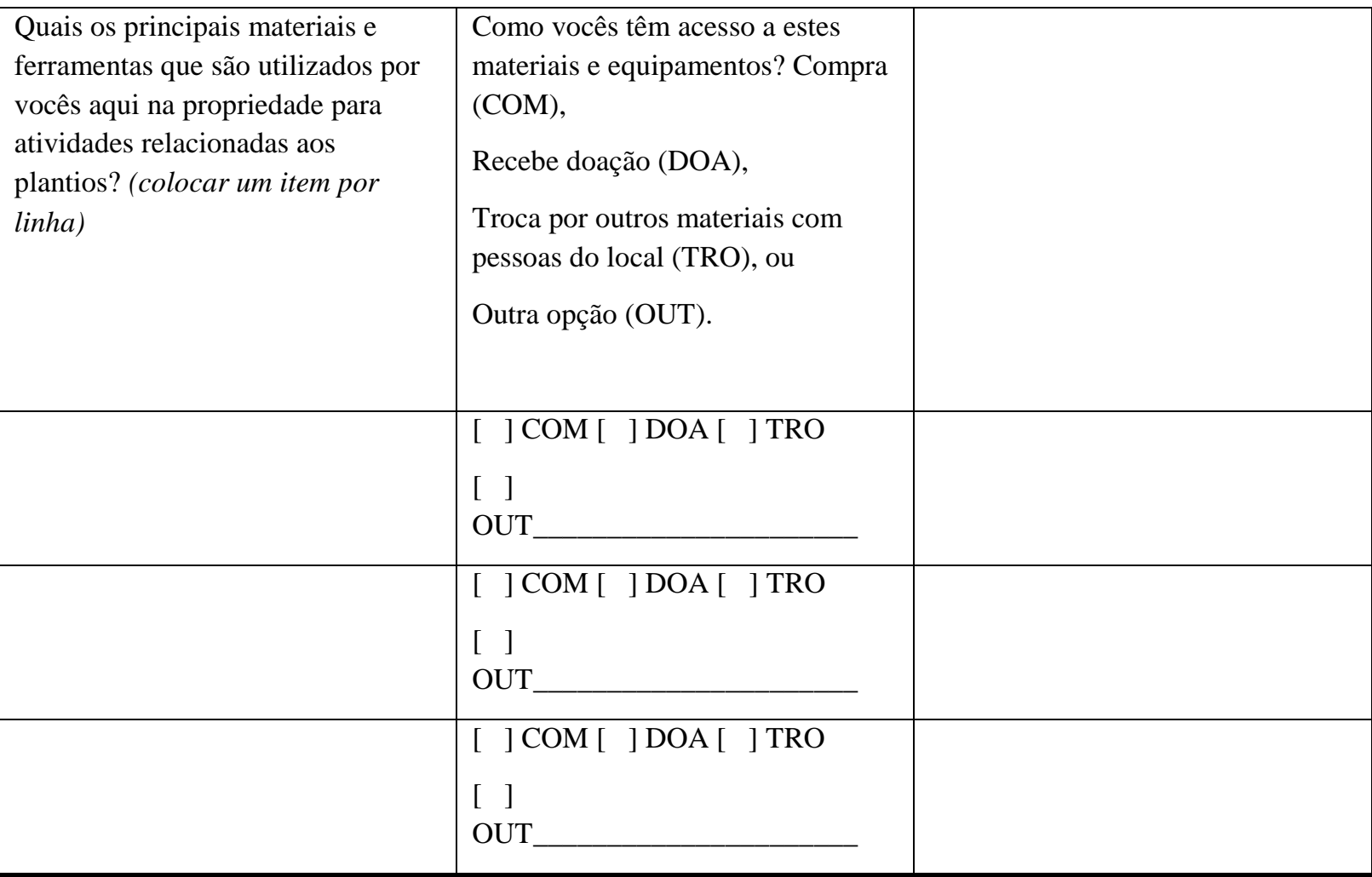

Desde ANO, vocês adquiriram conhecimento novo sobre leis ou normas que são aplicáveis ou importantes para as atividades agrícolas ou pecuárias que vocês fazem na propriedade? [ ] NÃO [ ] SIM.

Se sim, esse novo conhecimento foi adquirido por algum tipo de influência do projeto direta ou indireta do projeto de restauração Cafè com Floresta que ocorreu na região?

[ ] Sim. Como?

De que tratam essas leis ou normas que vocês passaram a conhecer:

\begin{tabular}{|l|l|l|}
\hline Lei/Norma referente a: & $\begin{array}{l}\text { Como foi adquirido } \\
\text { esse esclarecimento? }\end{array}$ & $\begin{array}{l}\text { Algum órgão fez monitoramento do cumprimento destas leis e } \\
\text { normas desde (falar dia e mês } \\
\text { equivalente ao do ano passado)? }\end{array}$ \\
\hline & & [ ] NÃO [ ] SIM. Qual? \\
\hline & [ ] N ̃̃O [ ] SIM. Qual? \\
\hline & [ ] NÃO [ ] SIM. Qual? \\
\hline
\end{tabular}

Desde ANO, vocês adquiriram conhecimento novo conhecimento sobre normas ou procedimentos que visam aumentar a segurança nas atividades desenvolvidas na propriedade ou garantir a saúde dos envolvidos da sua família 
ou que moram na sua propriedade?

[ ] NÃO [ ] SIM.

Se sim, esse novo conhecimento foi adquirido por algum tipo de influência do projeto direta ou indireta do projeto de restauração Café com Floresta que ocorreu na região?

[ ] Sim. Como?

De que tratam essas normas ou procedimentos que vocês passaram a conhecer:

\begin{tabular}{|l|l|l|}
\hline Lei/Norma referente a: & $\begin{array}{l}\text { Como foi } \\
\text { adquirido esse } \\
\text { esclarecimento? }\end{array}$ & $\begin{array}{l}\text { Algum órgão fez monitoramento do cumprimento destas leis e } \\
\text { normas desde _falar dia e mês equivalente } \\
\text { ao do ano passado)? }\end{array}$ \\
\hline & & [ ] NÃO [ ] SIM. Qual? \\
\hline & & [ ] ] NÃO [ ] SIM. Qual? \\
\hline & & [ ] NÃO [ ] SIM. Qual? SIM. Qual? \\
\hline
\end{tabular}

\section{PARTE B - PROCESSO PARTICIPATIVO}

Agora, gostaria de conversar sobre algumas atividades referentes às decisões e definições dentro do projeto de restauração, se o(a) senhor(a) foi envolvido, seu nível de inclusão e participação.

$\mathrm{O}(\mathrm{a})$ senhor(a) foi consultado pelos gestores do projeto de restauração para discutirem, planejar e opinar sobre as atividades e ações relacionadas ao projeto de restauração?

[ ] NÃO [ ]SIM

\begin{tabular}{|l|l}
\hline Se sim, quais assuntos foram abordados nessas conversas? & Em que mês e ano,
\end{tabular} aproximadamente, essa consulta ocorreu?

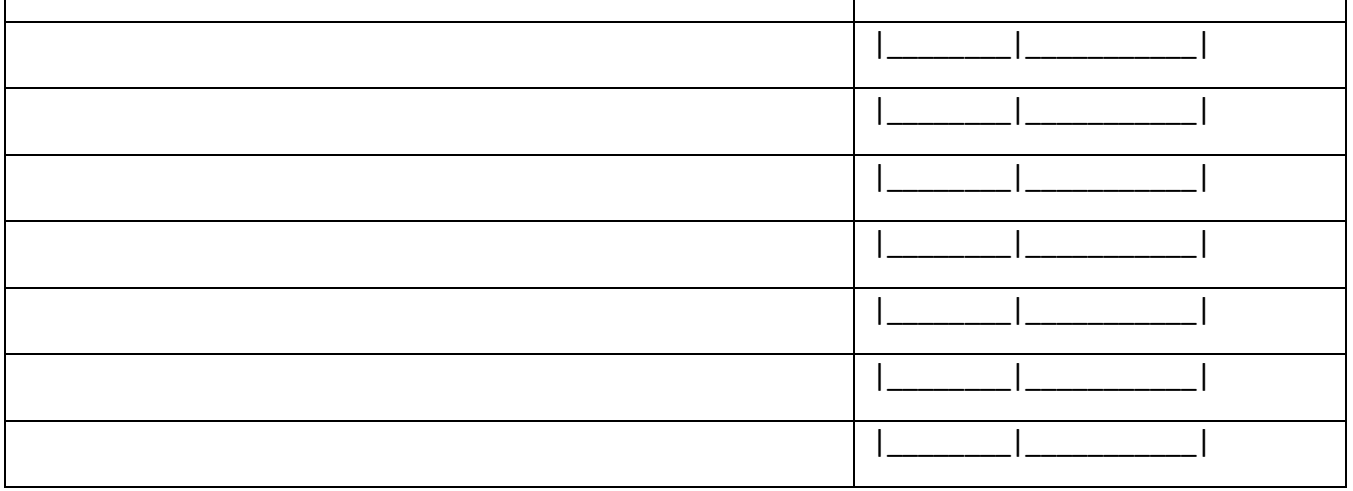

O(a) senhor(a) ou alguma pessoa da sua família ou que mora na sua propriedade participou de reuniões ou outros eventos para discutir e planejar alguma ação ou atividade de restauração, ou seja, de outras práticas de agricultura ou pecuária, ou então do plantio de árvores nas propriedades da região?

[ ] NÃO [ ]SIM

Se sim, quantas reuniões e eventos vocês participaram desde

I___ | reuniões (dizer data de hoje no ano passado)?

Agora eu gostaria que o senhor(a) me falasse de cada um desses eventos que vocês participaram, começando pelo primeiro, ou seja, aquele mais antigo.

\begin{tabular}{|l|l|l|l|l|}
\hline $\begin{array}{l}\text { Qual foi o } \\
\text { principal assunto }\end{array}$ & $\begin{array}{l}\text { Como ficou } \\
\text { sabendo deste }\end{array}$ & $\begin{array}{l}\text { Quais foram os motivos pelos } \\
\text { quais você foi chamado para }\end{array}$ & $\begin{array}{l}\text { Nessas } \\
\text { reuniões, quais }\end{array}$ & $\begin{array}{l}\text { Caso nesse encontro } \\
\text { tenham sido discutidas as }\end{array}$ \\
\hline
\end{tabular}




\begin{tabular}{|c|c|c|c|c|}
\hline $\begin{array}{l}\text { que foi tratado } \\
\text { nesse encontro? }\end{array}$ & $\begin{array}{l}\text { evento? } \\
\text { (Preencher com } \\
\text { opções a segui } \\
\text { Convite de gestor } \\
\text { do projeto (GES) } \\
\text { Convite de } \\
\text { conhecido (CON) } \\
\text { Divulgação } \\
\text { (meios } \\
\text { comunicação } \\
\text { (Div) } \\
\text { Outros (detalhar) }\end{array}$ & $\begin{array}{l}\text { participar do evento? } \\
\text { (Preencher com opções a } \\
\text { seguir: } \\
\text { Indicação (IND) } \\
\text { Conhecia os gestores (GES) } \\
\text { Participou de processo de } \\
\text { seleção (SEL) } \\
\text { Viu divulgação e quis participar } \\
\text { (DIV) } \\
\text { Outro (detalhar) }\end{array}$ & $\begin{array}{l}\text { eram as suas } \\
\text { demandas, } \\
\text { necessidades } \\
\text { e/ou } \\
\text { preferências, } \\
\text { relacionadas às } \\
\text { atividades } \\
\text { desenvolvidas } \\
\text { no projeto de } \\
\text { restauração? }\end{array}$ & $\begin{array}{l}\text { demandas, necessidades e } \\
\text { preferências dos durante o } \\
\text { evento, alguma delas foi } \\
\text { incorporada no projeto de } \\
\text { restauração? } \\
\text { Se sim, qual? }\end{array}$ \\
\hline & & & & $\begin{array}{l}\text { [ ] ] NÃO. Qual? } \\
\text { [ ] SIM. Qual? }\end{array}$ \\
\hline & & & & $\begin{array}{l}\text { [ ] ] NÃO } \\
\text { [ ] SIM. Qual? }\end{array}$ \\
\hline & & & & $\begin{array}{l}\text { [ ] NÃO } \\
\text { [ ] SIM. Qual? }\end{array}$ \\
\hline & & & & $\begin{array}{l}\text { [ ] ] NÃO } \\
\text { [ ] SIM. Qual? }\end{array}$ \\
\hline & & & & $\begin{array}{l}\text { [ ] NÃO } \\
\text { [ ] SIM. Qual? }\end{array}$ \\
\hline
\end{tabular}

Com base, principalmente nestas demandas e necessidades, existiram conflitos, desavenças ou diferença de opiniões entre as pessoas envolvidas na reunião ou entre participantes do projeto de restauração e aqueles que não se envolveram? Ou seja, há assuntos sobre os quais os participantes discordaram, sejam estes tanto os moradores, os proponentes ou então de outros órgãos? [ ] NÃO [ ]SIM

\begin{tabular}{|l|l|l|l|}
\hline $\begin{array}{l}\text { Se sim, sobre qual } \\
\text { tema houve conflito, } \\
\text { desavenças ou } \\
\text { diferenças? }\end{array}$ & $\begin{array}{l}\text { Qual foi especificamente } \\
\text { o conflito ou a } \\
\text { desavença em relação ao } \\
\text { tema em questão? }\end{array}$ & $\begin{array}{l}\text { Entre quais grupos participantes } \\
\text { ocorre este conflito? Por } \\
\text { exemplo, entre proprietários de } \\
\text { pequenas e de grandes } \\
\text { propriedades, proprietários } \\
\text { diferentes, pessoas de sexo ou } \\
\text { idade diferentes. }\end{array}$ & $\begin{array}{l}\text { Esse aspecto foi determinante } \\
\text { para a sua não participação no } \\
\text { projeto? }\end{array}$ \\
\hline & & & [ ] NÃO [ ] SIM. Por que? \\
\hline & & & [ ] NÃO [ ] SIM. Por que? \\
\hline
\end{tabular}




\begin{tabular}{|l|l|l|l|}
\hline & & & \\
\hline & & & [ ] NÃO [ ] SIM. Por que? \\
& & & \\
\hline
\end{tabular}

Caso tenha participado de eventos ou reuniões desse projeto, durante estes momentos ocorreram situações de conflito, desavenças ou diferenças de opiniões entre os participantes? [ ] ] NÃO [ ]SIM

\begin{tabular}{|l|l|l|}
\hline $\begin{array}{l}\text { Se ocorreram conflitos, desavenças ou diferenças de } \\
\text { opinião, sobre quais assuntos eles ocorreram? }\end{array}$ & $\begin{array}{l}\text { Os gestores do projeto } \\
\text { tomaram alguma medida } \\
\text { para resolver este problema? }\end{array}$ & $\begin{array}{l}\text { Qual medida foi tomada para } \\
\text { resolver este problema? }\end{array}$ \\
\hline & [ ] NÃO [ ] SIM & \\
\hline & [ ] NÃO [ ] SIM & \\
\hline & [ ] NÃO [ ] SIM & \\
\hline & [ ] NÃO [ ] SIM & \\
\hline & [ ] NÃO [ ] SIM & \\
\hline
\end{tabular}

As definições e decisões sobre as atividades a serem implementadas no projeto foram feitas com base no que foi discutido através das consultas individuais e eventos em grupo? Ou seja, alguma opinião do(a) senhor(a) foi levada em conta e incluída no processo de tomada de decisão e nas atividades implementadas no projeto em outras propriedades? [ ] NÃO [ ] SIM

Se não, esse fator foi um fator determinante para a sua não participação do projeto? [ ] NÃO [ ] SIM

Se sim, quais contribuições do(a) senhor(a) foram incorporadas ao projeto?

1.

2.

3.

4.

5.

6.

7.

$\mathrm{O}(\mathrm{a})$ senhor(a) possui algum tipo de conhecimento relacionado às atividades que são desenvolvidas no projeto de restauração em outras propriedades? Ou seja, conhecimento de aspectos como, por exemplo, o local ou a forma que deve ser feito o plantio das mudas das árvores e outras plantas escolhidas; conhecimento sobre a preparação do solo para o plantio; outras informações sobre a manutenção ou cuidado com os plantios; ou, por fim, da exploração dos plantios depois?

[ ] NÃO [ ] SIM [ ] NÃO SEI 


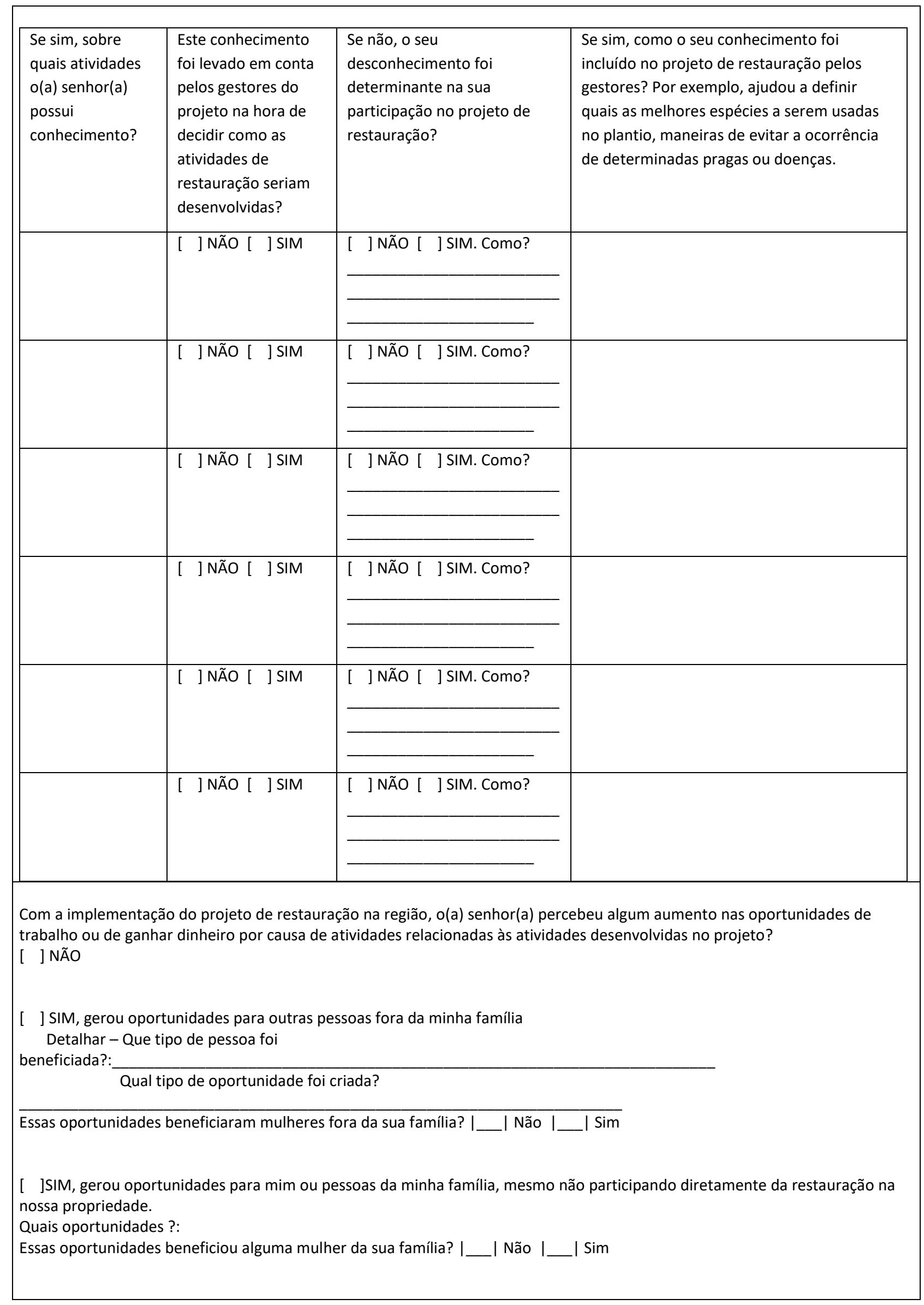




\begin{tabular}{|l|l|}
\hline $\begin{array}{l}\text { Se sim, quais são os trabalhos que o senhor ou alguém da sua } \\
\text { família já realizou desde__ (dizer dia e mês equivalente } \\
\begin{array}{l}\text { ao do ano anterior) até hoje que foram consequência do } \\
\text { projeto? }\end{array}\end{array}$ & $\begin{array}{l}\text { Quanto o senhor(a) ou a pessoa da sua família } \\
\text { ganhou em dinheiro por realizar este trabalho } \\
\text { desde_dizer dia e mês equivalente ao } \\
\text { Por favor, cite todos, começando com aquele mais } \\
\text { importante. }\end{array}$ \\
\hline & \\
\hline & \\
\hline & \\
\hline & \\
\hline
\end{tabular}

Se sim, como costumam gastar o dinheiro que conseguiram através da realização destes trabalhos?

\begin{tabular}{|c|c|c|}
\hline $\begin{array}{l}\text { Compras domésticas: como } \\
\text { alimento, roupas, móveis, } \\
\text { eletrodomésticos }\end{array}$ & [ ] NÃO [ ] SIM & Especificar: \\
\hline $\begin{array}{l}\text { Investimento na estrutura da } \\
\text { propriedade }\end{array}$ & [ ] NÃO [ ] SIM & Especificar: \\
\hline $\begin{array}{l}\text { Compra de materiais para } \\
\text { manutenção da área de } \\
\text { restauração }\end{array}$ & [ ] NÃO [ ] SIM & Especificar: \\
\hline $\begin{array}{l}\text { Compra de materiais para plantio } \\
\text { em outras áreas }\end{array}$ & [ ] NÃO [ ] SIM & Especificar: \\
\hline Investimento em educação/cursos & [ ] NÃO [ ] SIM & Especificar: \\
\hline Poupança & [ ] NÃO [ ] SIM & Especificar: \\
\hline Outros: & [ ] NÃO [ ] SIM & Especificar: \\
\hline Outros: & [ ] NÃO [ ] SIM & Especificar: \\
\hline
\end{tabular}

Desde a fase de planejamento do projeto de restauração até hoje, o(a) senhor(a) teve conhecimento sobre algum canal de comunicação para poder conseguir informações projeto de restauração, ou então tirar dúvidas e fazer sugestões? Por exemplo, o nome e telefone de contato de alguém, algum whatsapp, um site da internet ou internet, um escritório para ir conversar? [ ] NÃO [ ] SIM

Se sim, quais canais foram disponibilizados pelas pessoas do projeto para entrar em contato?

1)

2)

3)

\section{PARTE C - RESULTADOS}

Agora, gostaríamos de falar se o projeto de restauração implantado na região gerou algum impacto para o(a) senhor, sua família e propriedade. 


\begin{tabular}{|c|c|c|c|c|}
\hline \multicolumn{5}{|c|}{$\begin{array}{l}\text { O(a) senhor(a) adquire, através de troca ou compra algum produto ou cultivo que foi plantado em áreas de restauração desse } \\
\text { projeto? Por exemplo o café que é produzido por algumas famílias em um tipo de plantio que é desenvolvido junto com outras } \\
\text { espécies de árvores, chamado de "Café com Floresta". [ ] NÃO [ ] SIM }\end{array}$} \\
\hline \multirow[t]{7}{*}{$\begin{array}{l}\text { Se sim, por favor, } \\
\text { gostaria que o } \\
\text { senhor(a) me dissesse } \\
\text { qual é o principal } \\
\text { produto, cultivo ou } \\
\text { plantio que já } \\
\text { adquiriu. } \\
\text { E depois desse, há } \\
\text { mais algum produto } \\
\text { ou plantio? }\end{array}$} & $\begin{array}{l}\text { Como o(a) senhor(a) } \\
\text { adquire estes cultivos? } \\
\text { Compra (COM) } \\
\text { Troca por outros produtos } \\
\text { com pessoas da região } \\
\text { (TRO) } \\
\text { Outros (OUT) }\end{array}$ & $\begin{array}{l}\text { De quem o(a) } \\
\text { senhor(a) adquire } \\
\text { este produto? } \\
\text { Empresa (EMP) } \\
\text { ONG (ONG) } \\
\text { Moradores Locais } \\
\text { (MOR) } \\
\text { Comerciantes } \\
\text { Locais }(\mathrm{COM})\end{array}$ & $\begin{array}{l}\text { De onde o(a) } \\
\text { senhor(a) } \\
\text { adquiria este } \\
\text { produto, antes de } \\
\text { começar a } \\
\text { adquirir através } \\
\text { das área de } \\
\text { restauração? }\end{array}$ & $\begin{array}{l}\text { Após a começar a } \\
\text { adquirir este produto } \\
\text { das áreas de } \\
\text { restauração, o senhor } \\
\text { diria que o total de } \\
\text { dinheiro que vocês } \\
\text { gastam com estes } \\
\text { produtos: } \\
\text { Diminuiu (DIM) } \\
\text { Permaneceu igual } \\
\text { (IGU) } \\
\text { Aumentou (AUM) }\end{array}$ \\
\hline & 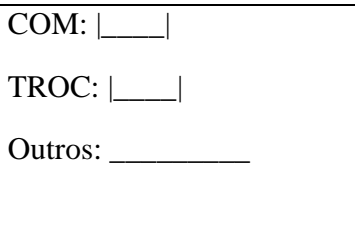 & 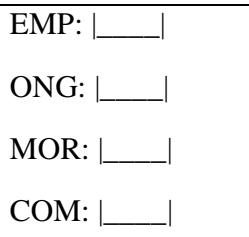 & & - \\
\hline & 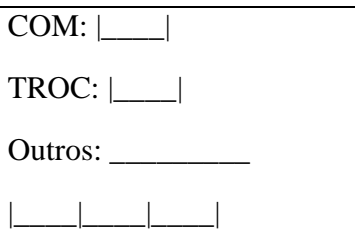 & 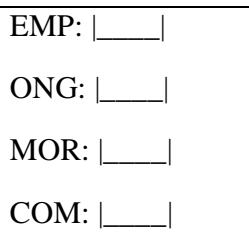 & & \\
\hline & $\begin{array}{l}\text { COM: } L_{\ldots} \mid \\
\text { TROC: }\left.\right|_{\perp} \mid \\
\text { Outros: }\end{array}$ & 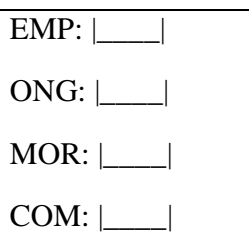 & & \\
\hline & $\begin{array}{l}\text { COM: } \text { L__ }_{\text {TROC: }}{ }_{\perp} \\
\text { Outros: }\end{array}$ & 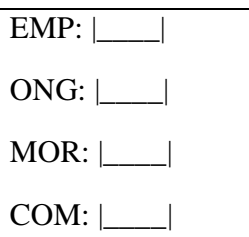 & & \\
\hline & $\begin{array}{l}\text { COM: }{ }_{\perp}{ }_{\text {TROC: }}{ }_{\perp} \\
\text { Outros: }\end{array}$ & 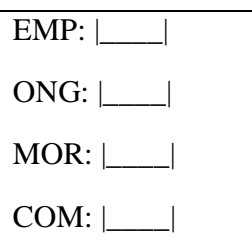 & & _- \\
\hline & $\begin{array}{l}\text { COM: } \text { L___ }_{\text {TROC: }}{ }_{\perp} \\
\text { Outros: }\end{array}$ & 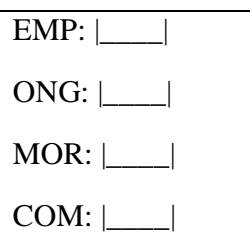 & & \\
\hline
\end{tabular}




\begin{tabular}{|l|l|}
\hline 1. \\
\hline 2. \\
\hline 3. \\
\hline 4. \\
\hline 5. \\
\hline 6. \\
\hline
\end{tabular}

Houve alguma mudança nas atividades realizadas durante o tempo livre de vocês que foram um resultado direto ou indireto do projeto de restauração em outras propriedades? Por exemplo, houve alguma atividade que, por conta do projeto, vocês passaram a fazer ou alguma que tiveram que deixar de fazer no tempo livre?

[ ] ] NÃO

[ ] SIM. O que

ocorreu?

Embora não tenha participado diretamente, o(a) senhor(a) considera que, atualmente, o projeto de restauração em outras propriedades trouxe algum retorno positivo para o(a) senhor(a), sua família, propriedade ou região?

[ ] NÃO [ ] SIM

Se sim, quais foram os retornos positivos em ordem de importância? (Anotar na ordem que falarem).

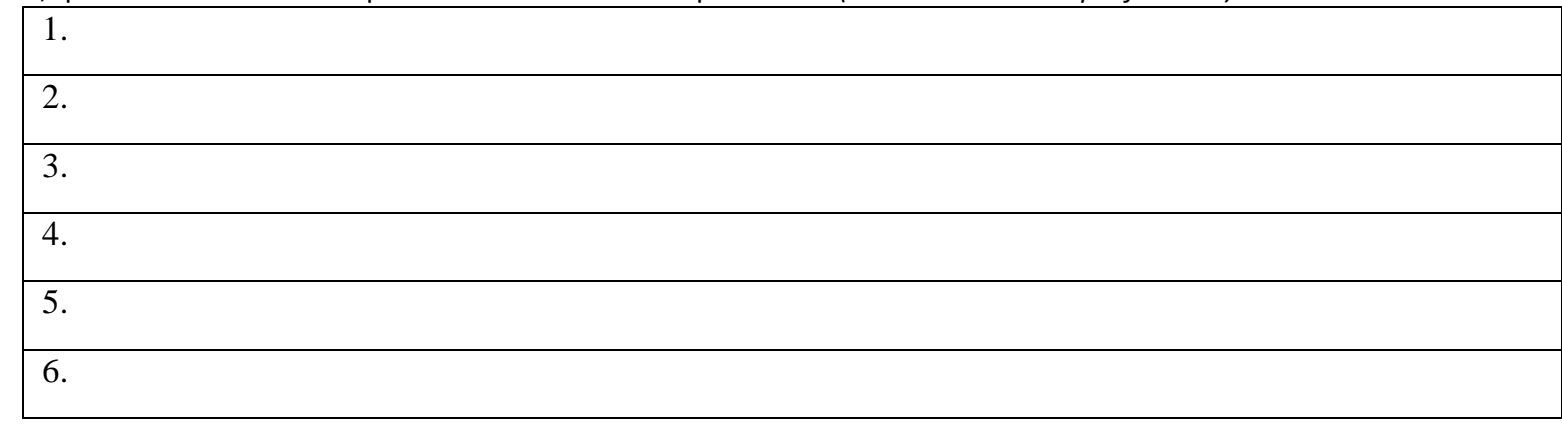

Da mesma forma, embora não tenha participado diretamente, o(a) senhor(a) considera que, atualmente, o projeto de restauração em outras propriedades trouxe algum retorno negativo ou trouxe algum problema para o(a) senhor(a), sua família, propriedade ou região?

[ ] ] NÃO [ ] SIM

Se sim, quais foram os impactos negativos em ordem de importância? (Anotar na ordem que falarem).

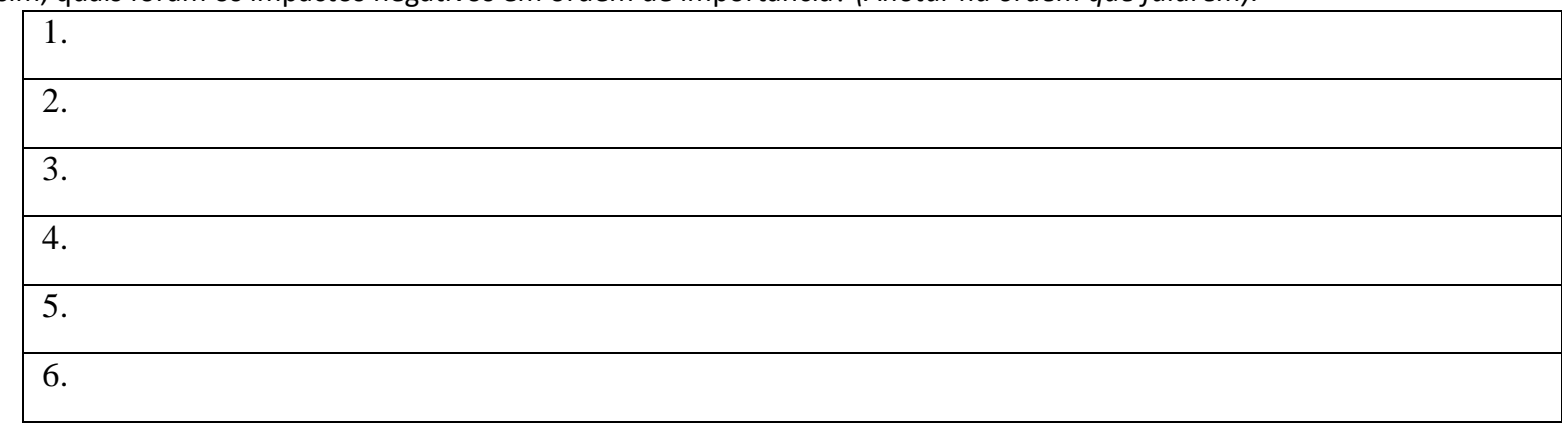

Se o senhor(a) fosse convidado hoje para participar de um novo projeto ou de uma nova fase do projeto de restauração, o senhor (a) aceitaria?

[ ] NÃO [ ] SIM

Se sim ou não, por quê?

De qual das atividades que que eu vou falar, o senhor escolheria participar:

a) plantio de agrofloresta na propriedade: I__ Não I_l Sim 


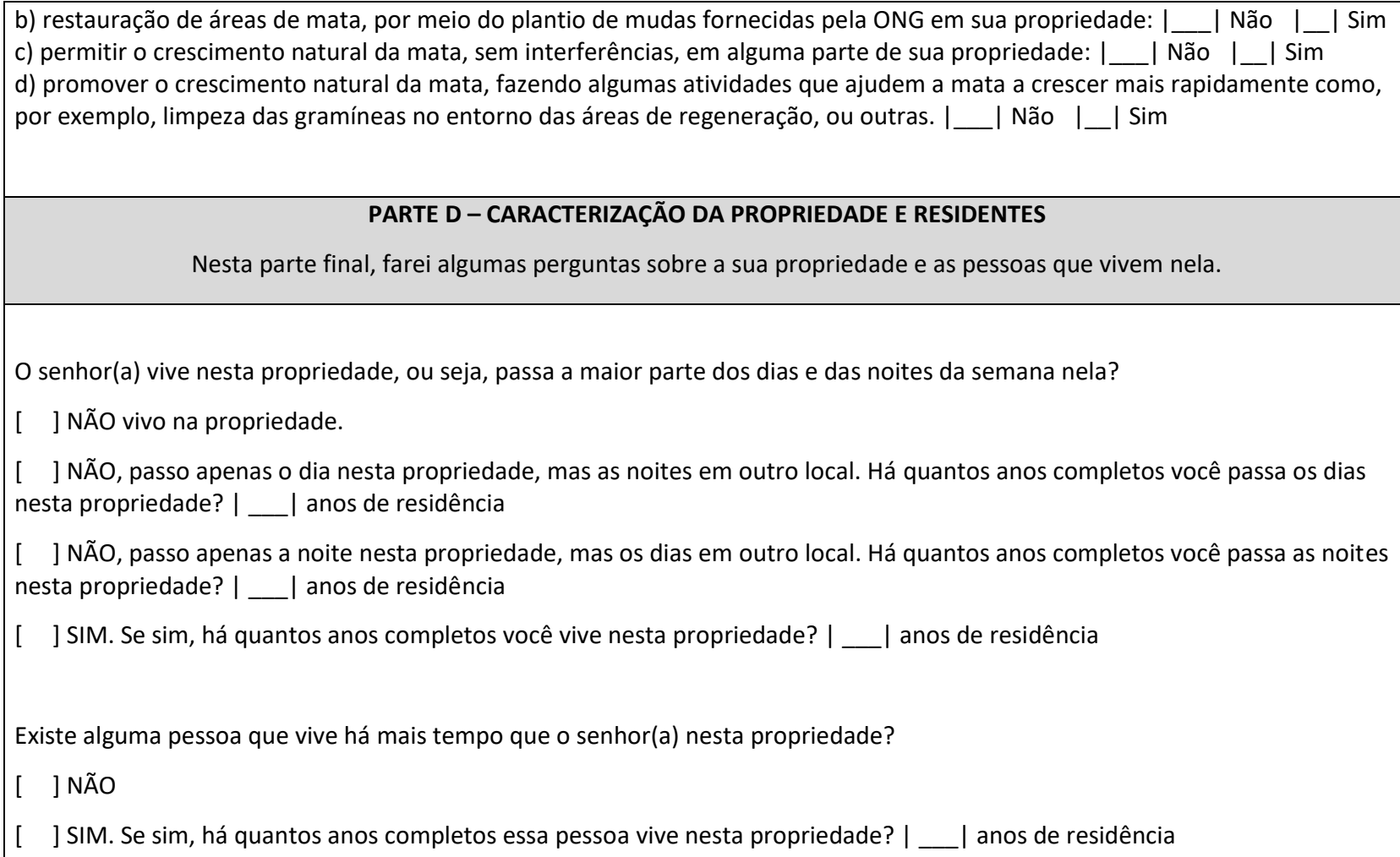

Nos próximos 5 anos, ou seja, de agora até 2024, você tem a intenção de se mudar para outro local, em uma outra região rural ou até mesmo para alguma cidade? [ ] NÃO [ ] SIM

Quantas pessoas, incluindo o(a) senhor(a), vivem nesta propriedade, ou seja, passam a maior parte dos dias e/ou das noites da semana nela? I__ l pessoas

Destas pessoas, quantas têm menos de 15 anos? |___ crianças

E quantas dessas pessoas têm 15 anos de idade ou mais? I___ adultos.

Dessas pessoas com mais de 15 anos, quantas têm algum problema ou limitação que as impede de trabalhar, ou seja, de exercerem atividades dentro ou fora da propriedade? ____ adultos limitados.

Em qual cidade de qual estado o senhor(a) nasceu? Cidade: Estado:

Qual é a data de nascimento do senhor(a)? ____________

Existe alguma pessoa que frequentou a escola por algum tempo nesta casa?

[ ] NÃO

[ ] SIM. Se sim, até qual série a pessoa que mais estudou na propriedade conseguiu chegar?

I__ série (escrever número da série)

Do: [ ] fundamental [ ] médio [ ] superior OUTRO(descrever):

E o senhor(a), frequentou a escola alguma vez na vida?

[ ] ] NÃO

[ ] SIM. Se sim, até qual série o senhor(a) conseguiu chegar?

I__ l série (escrever número da série) 


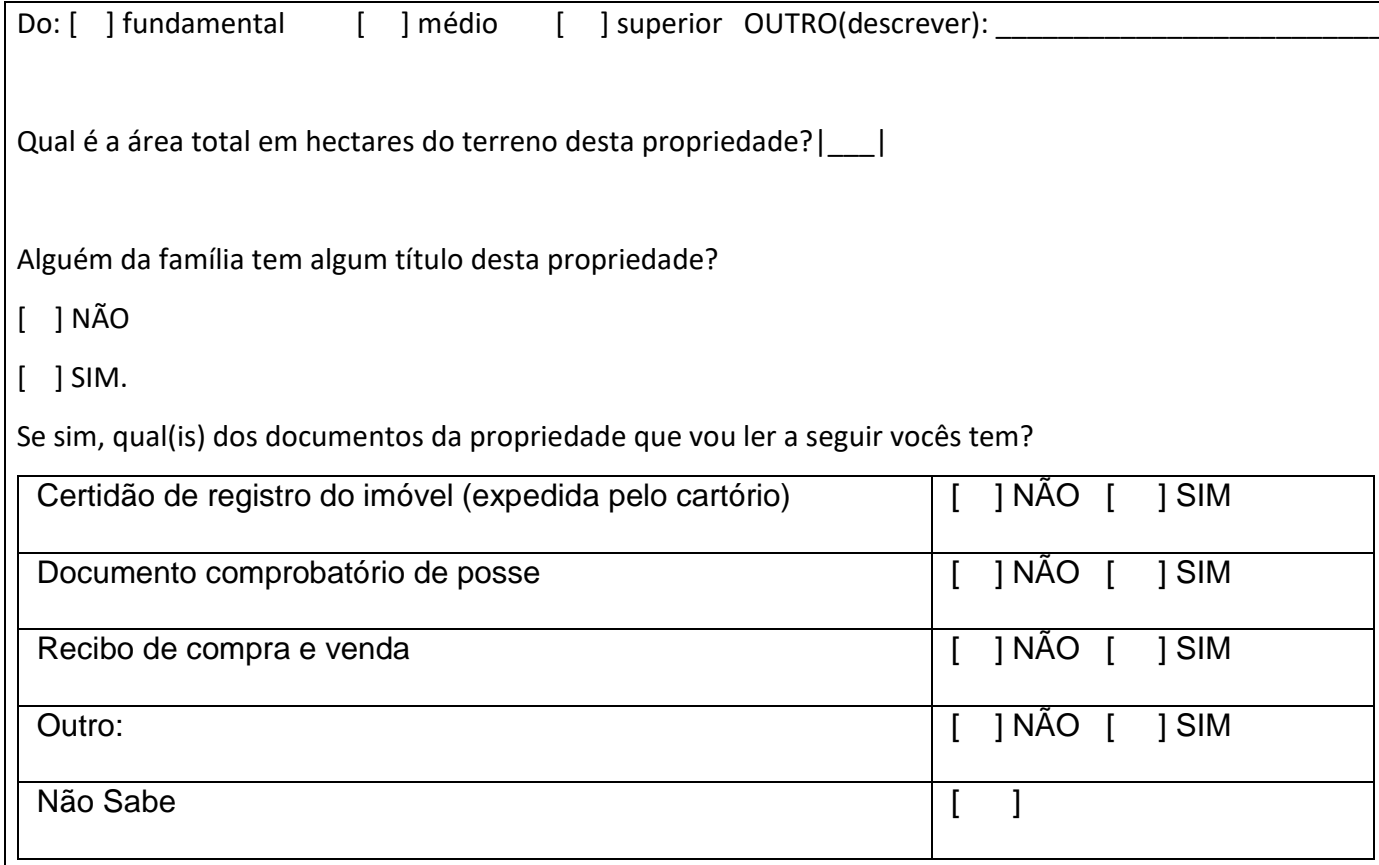

